Historic, archived document

Do not assume content reflects current scientific knowledge, policies, or practices. 


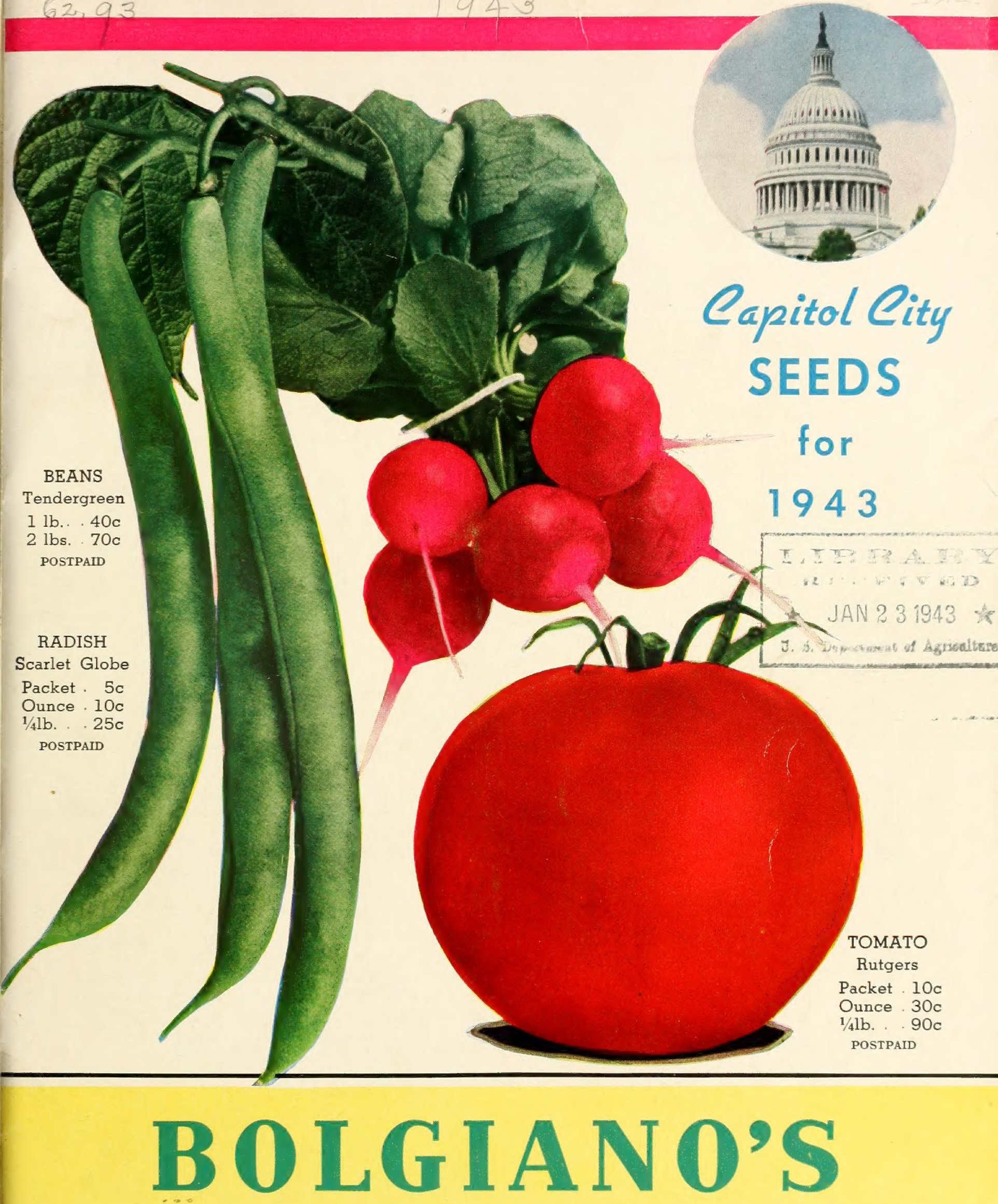

ESTABLISHED 1889

411 New York Ave. N. E.-Tel.: Franklin 4800

607 E Street N. W. - Tel.: National 0091 WASHINGTON,D.C. 


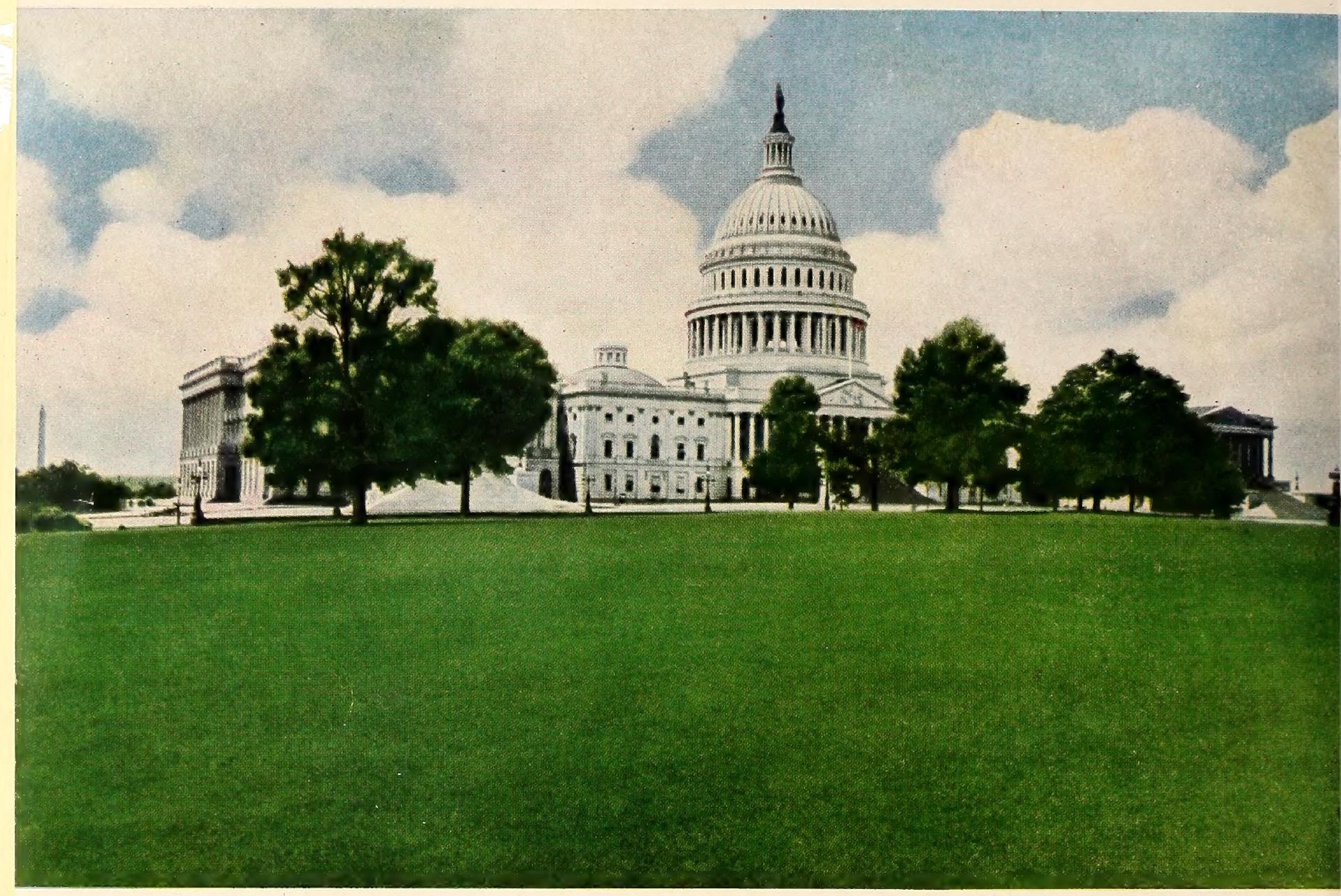

\section{BOLGIANO'S Capitol Park Lawn Grass Seed THE NATION'S PRIDE}

WE CAN say with pride that it is the accumulated experience of fifty years that has made possible the development of the "Capitol Park" Lawn Grass Mixture. It contains a carefully selected well-balanced blend of high quality recleaned seed. Through the years we have learned that the finest lawns for the Washington area are those made of fine bladed deep-rooting grass. It is an easy matter to have a good-looking lawn in spring but it is the year-around test that determines the quality of good lawn seed. We are proud of our Capitol Park Lawn Seed and we believe you will find this leader in the Washington area the answer to your lawn problem.

\section{Price: Lb., 35c; 3 lbs., \$1.00; 5 Ibs., \$1.65; 10 lbs., $\$ 3.25 ; 25$ lbs., $\$ 7.50$}

\section{PLANT FOOD FOR YOUR LAWN}

Grass, like every other plant, requires food and regular feeding insures success.

Our Bolgiano's Gold Tag Lawn Fertilizer and the nationally known Loma and Vigoro and Wizard Brand Sheep Manure are the best lawn foods we know of and used regularly will keep your lawn looking as you want it to.
Get a supply of one of these when you buy your grass seed and always keep a supply on hand to apply when needed.

For prices on these lawn foods and other fertilizers see fertilizer pages in back of catalogue.

PAMPHLET, "How to Make a Beautiful Lawn," free on request with every purchase of Lawn Seed.

\section{BOLGIANO'S. WASH INGTON, D. C.}




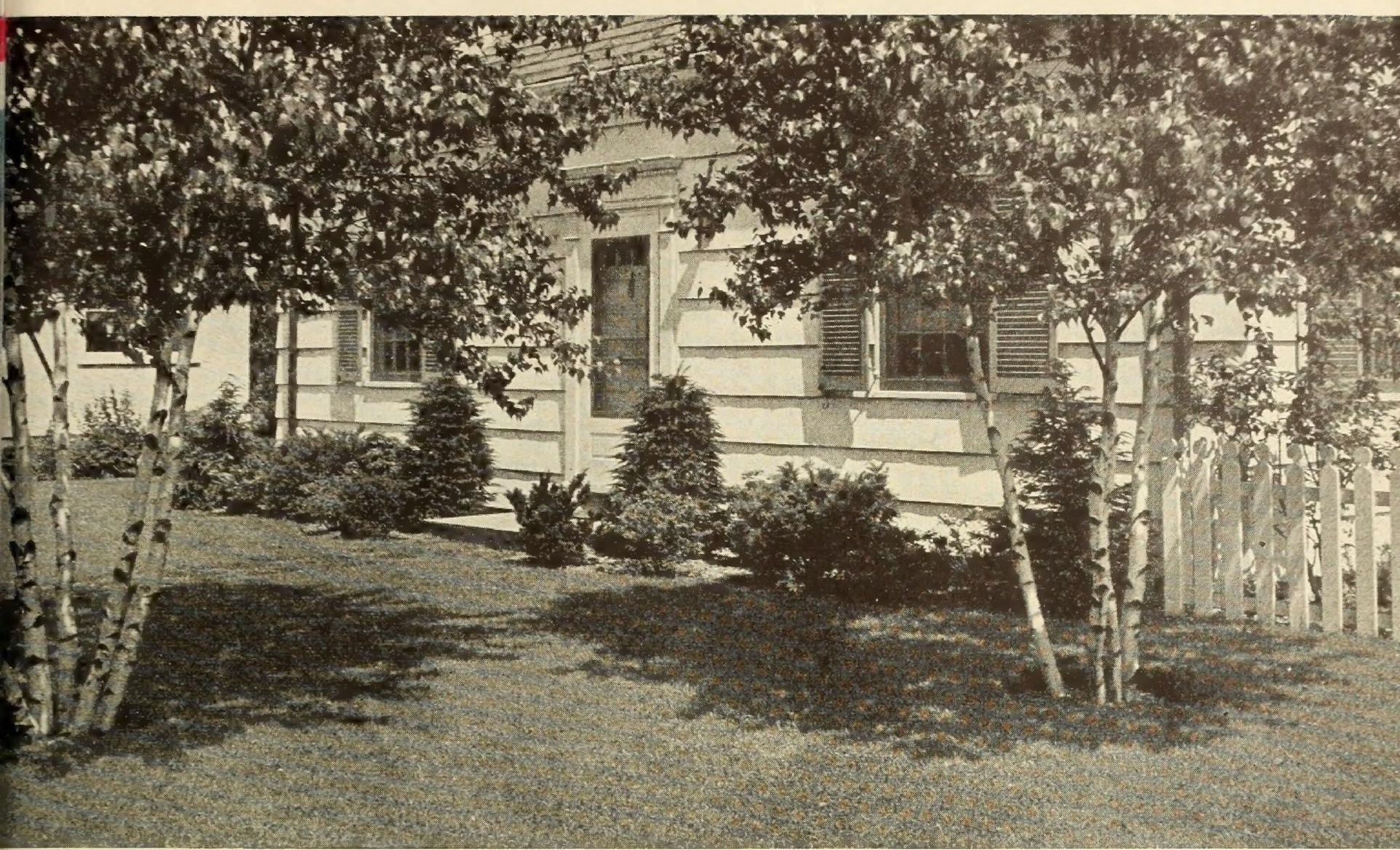

\section{BOLGIANO'S MODERN LAWN GRASS MIXTURES}

\section{BOLGIANO'S "WHITE HOUSE" SHADY LAWN GRASS SEED}

The Grass That Will Grow in Shady Places

To provide a turf for shady places which would match the turf of our Capitol Park Lawn Grass in the sun we experimented with grasses best adapted for growing in the shade until this formula was perfected. The resulting White House Shady Lawn Seed has removed cause for worry about those once bad places under trees.

Lb. 45 c.; 5 lbs. $\$ 2.00 ; 10$ lbs. $\$ 3.75 ; 25$ lbs. $\$ 8.75$

\section{HORMONE-TREATED LAWN SEED}

Treating seeds with Rootone Hormone Powder serves to augment the natural hormones which stimulate root-formation and top-growth. In our Hormone-treated Lawn Grass Mixture we use only the best varieties of seed, including Bent Grass.

Lb. 70 c.; 10 lbs. $\$ 6.50 ; 25$ lbs. $\$ 15.00$

\section{PUTTING GREEN GRASS}

Our Bent Grasses for putting-greens are unsurpassed.

“Blue Tag" Certified Astoria Bent. Lb. $\$ 1.00 ; 5$ lbs. $\$ 4.75$; 25 lbs. \$21.25.

“Blue Tag" Certified Seaside Bent. Lb. 95c.; 5 lbs. $\$ 4.50$; 25 lbs. $\$ 20.00$.

\section{BOLGIANO'S "FAIRGREEN" \\ LAWN GRASS SEED}

A Superior Mixture with Creeping Bent

Selecting grasses capable of producing a dense velvety lawn and resistant to dry summer weather, we believe we have in Fairgreen a permanent turf mixture which is unsurpassed, especially on slopes and terraces.

Lb. 60 c.; 5 lbs. $\$ 2.75 ; 25$ lbs. $\$ 12.50$

\section{WHITE DUTCH CLOVER (Trifolium repens)}

Some White Clover is usually included in lawn grass mixtures as it makes an excellent turf that stands constant trampling. It is of dwarf habit, spreads rapidly and is very hardy.

Lb. $\$ 1.00 ; 5$ lbs. $\$ 4.75 ; 25$ lbs. $\$ 21.25$

\section{KENTUCKY BLUE GRASS (Poa pratensis)}

This is undoubtedly the best of lawn grasses for neutral soils. Its splendid root system forms a tough sod that will stand hot, cold or dry weather. Although Blue Grass requires about two years to get well established, it is well worth waiting for. Can be sown in a mixture of other grasses. Sow in fall or spring at the rate of 5 pounds per 1000 square feet.

Lb. 35 c. 10 lbs. $\$ 3.00 ; 25$ lbs. $\$ 6.00$

\section{RED-TOP (Agrostis vulgaris)}

A valuable, permanent, narrow-blade grass especially adapted to our climate. Used in most lawn mixtures.

Lb. 30c.; 10 lbs. $\$ 2.50 ; 25$ lbs. $\$ 4.25$

\section{DOMESTIC RYE GRASS}

A quick-growing grass used as a nurse-crop in many lawn mixtures. Sow 10 pounds per 1000 square feet of Iawn.

Lb. 20 c.; 10 lbs. $\$ 1.50 ; 25$ lbs. $\$ 3.00$

\section{CHEWING'S FESCUE}

This important component of all good shady lawn mixtures forms a low, dense, mat-like turf of fine needle-like leaves. It is popular for lawns and golf courses because of its droughtresistance and ability to thrive on most soils. If used alone, sow 8 pounds per 1000 square feet.

Lb. 60 c.; 5 lbs. $\$ 5.50 ; 25$ lbs. $\$ 12.50$

Prices quoted on grass seed do not include postage. See page 2 for Parcel Post rates. If postage is included with order, seed will be sent by Parcel Post, otherwise shipment will be made by Express Collect. 


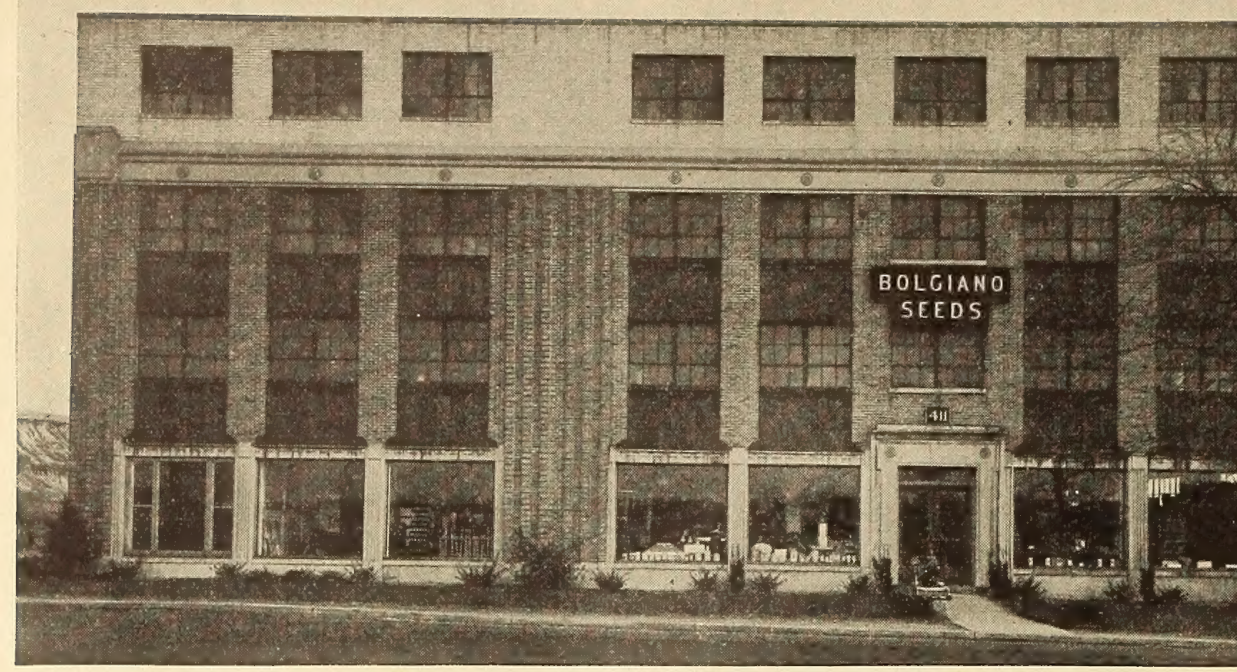

411 NEW YORK AVENUE, N. E.

Phone: Franklin 4800

\section{Two Convenient Stores \\ in Washington, D.C.}

OFFICERS

Mrs. Charles W. Bolgiano Mrs. G. E. Ward Raymond B. Ward C. Blakeley Arthur President

Vice-President

Gen'l Mgr. and Treasure

Asst. Mgr. and Sec.

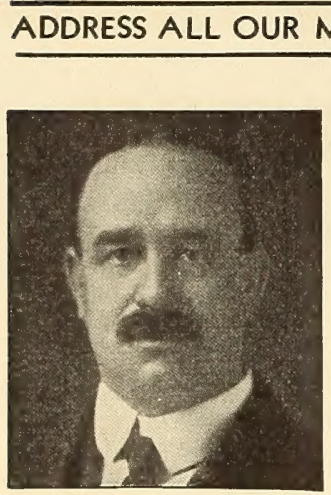

FRANK W. BOLGIANO Founder

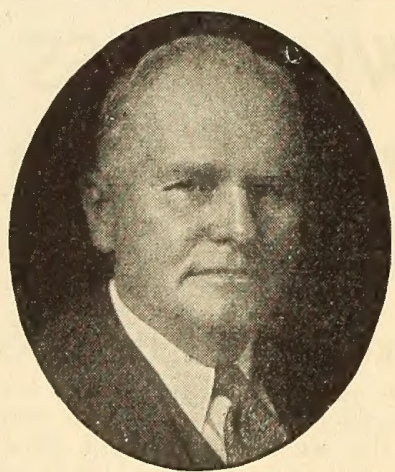

RA YMOND B. WARD General Manager

\section{- TERMS OF BUSINESS —}

ADDRESS ALL MAIL to F. W. Bolgiano \& Co., 411 New York Ave. N. E., Washington, D. C.

SEEDS DELIVERED FREE. We pay postage on all Packets, Ounces, Quarter Pounds, or Pounds of Vegetable and Flower Seeds, ordered at list prices. This also applies to Peas, Beans, and Sugar Corn up to 5 pounds; larger quantities than these, carrying charges extra. This does not apply to Field and Grass Seeds, Seed Potatoes or Flowering Plants, which will be sent at regular Parcel Post or Express Rates.

OUR TERMS are always cash with order, or satisfactory New York, Philadelphia or Washington reference.

MONEY can be sent at our risk by Post-Office or Express Money Order, New York or Chicago Draft, or by Registered Letter. We cannot hold ourselves responsible for cash sent loose in letters.

AN ORDER BLANK for your convenience in placing your order will be found in this Catalog.

NAME AND ADDRESS should be written plainly both on the Order Blank and on the envelope enclosing the order. Names of seeds and plants should be written out in full in plain writing.

EXPRESS or FREIGHT shipments should have the name of the station plainly given where different from the Post Office.

ORDER EARLY. We aim to fill all orders within twenty-four hours after receipt. Please do not wait until the extreme rush season when there are more chances for delay.

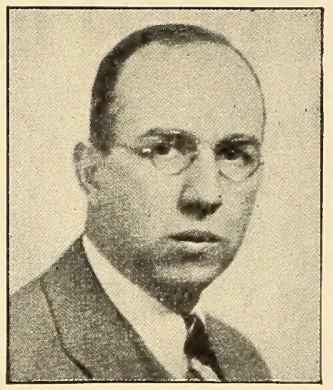

CHARLES W. BOLGIANO Pres. 1923-1938

GIVE FULL DIRECTIONS always whether shipment is to be made by Freight, Express or Parcel Post.

SAFE ARRIVAL. We guarantee safe arrival of all goods sent by Express or Mail to any point within the United States proper.

NON-WARRANTY. We give no warranty, expressed or implied, as to description (including kind, variety and name) quality or productiveness, or any other matter of any seeds, plants or bulbs we send out, and will not be in any way responsible for the crop.

\section{DOMESTIC PARCEL POST RATES}

On Seeds, Plants, Bulbs, Roots, Garden, Lawn and Poultry Supplies WITHIN THE U. S. AND POSSESSIONS

Local Rate, Washington and Suburbs only

1st and $2 \mathrm{~d}$ Zone, within 150 miles of Washington, D. C

$3 \mathrm{~d}$ Zone, between 150 and 300 miles

4th Zone, between 300 and 600 miles

5 th Zone, between 600 and 1000 miles.

6 th Zone, between 1000 and 1400 miles

7th Zone, between 1400 and 1800 miles 8th Zone, over 1800 miles.

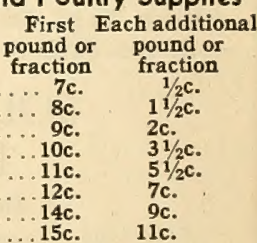

A fraction of a cent in the total amount on any parcel counts as a full cent.

\section{WEIGHTS BY PARCEL POST}

Parcels up to 70 pounds can be sent by Parcel Post to all the zones.

To points farther than the 4 th Zone on weight of over 10 pounds, the charge by Freight or Express is usually more economical.

\section{ALL PRICES IN THIS CATALOG ARE SUBJECT TO CHANGE WITHOUT NOTICE}




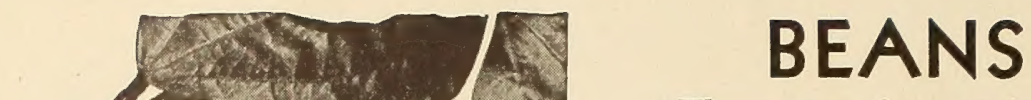

There are five varieties of Beans illustrated on this page covering exceptionally good varieties of green, wax, lima and pole beans. They are fully described alphabetically under their classification and offer a wide choice for the most discriminating gardener, and will add to your enjoyment if you grow these this coming season.

\section{THE POLE BEANS}

Pictured on this page is one of the all-round useful Pole Beans which can be used as Snap Beans, green Shell Beans or the dried Beans of winter. A useful group indeed.

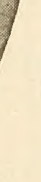

ALL PRICES SUB JECT TO CHANGE ountiful Beans. Pkt. 10c.

\section{VARIETY FOR YOUR TABLE}

With all food becoming scarcer, every gardener will plant aII he can use fresh and to preserve for winter. Don't overlook the chance to pep up the diet by growing some of those "out of the ordinary" vegetables. You may find a new favorite.

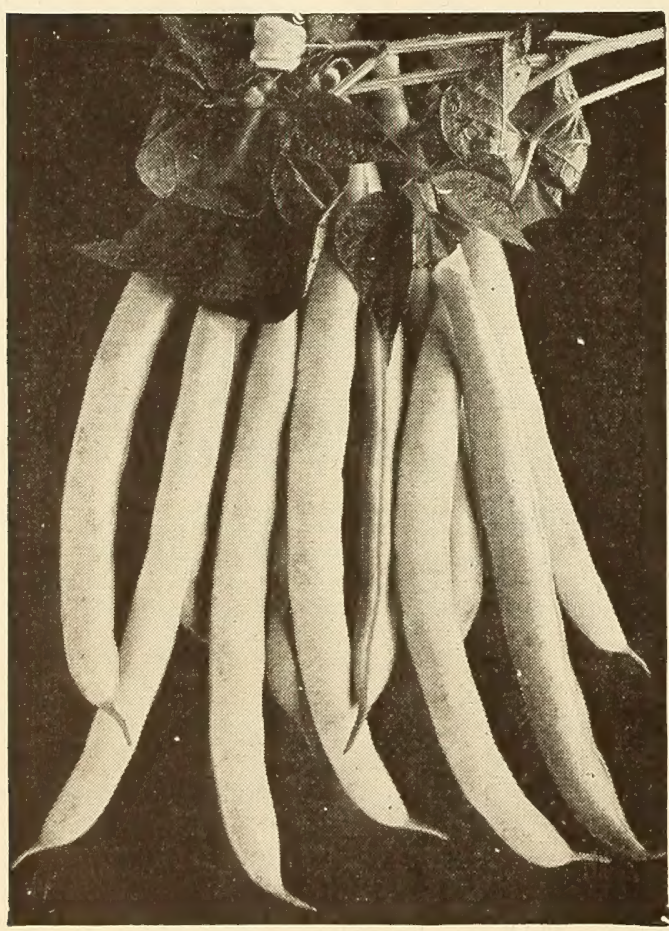

541. Bolgiano's Best Yet Wax Beans. Pkt. 10c.

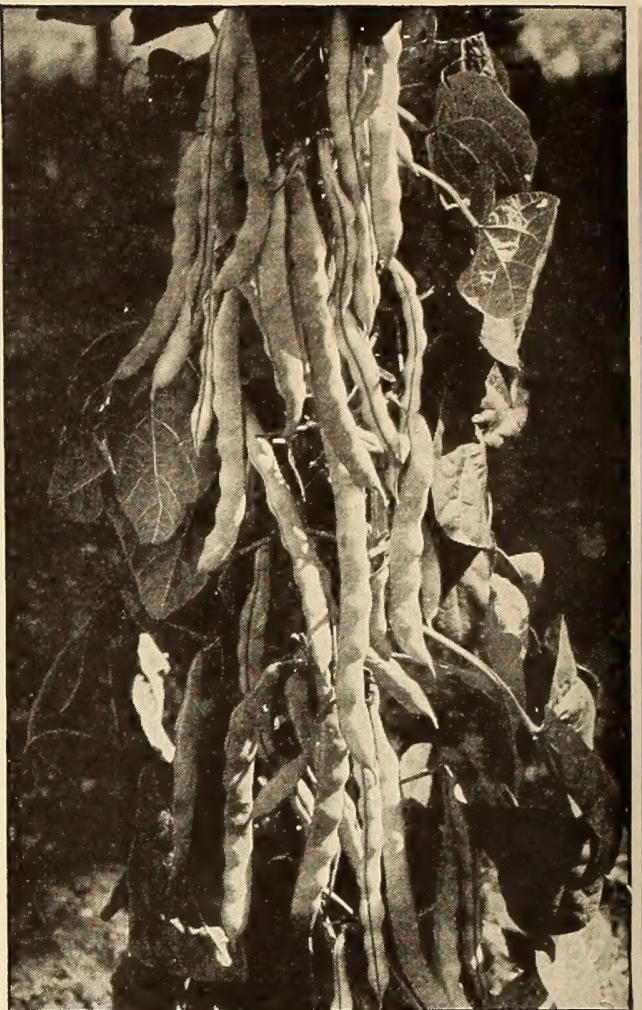

553. Kentucky Wonder Pole Beans. Pkt. 10c.

\section{FIGHT THE BEAN BEETLE}

Keep the plants free of pests so they can produce a full crop of this splendid vegetable. Protect the foliage against the pestiferous Mexican bean beetle by keeping dusted with Acme Pyrethrum Garden Guard. See page 69.

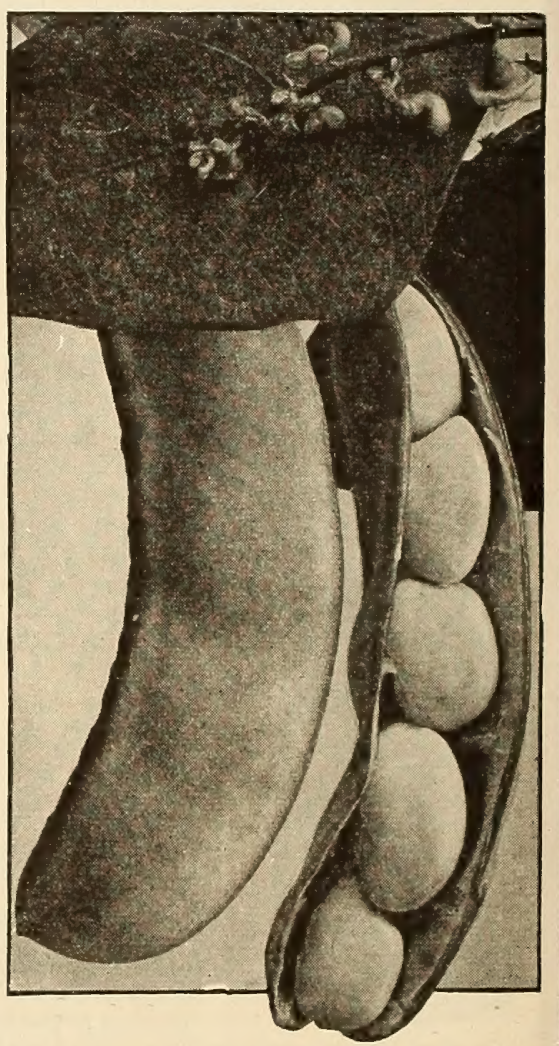

517. Evergreen Pole Lima Beans. Pkt. 10c. 


\section{B E A N S}

Every garden, Iarge or small, must have Beans which are among the finest of all vegetables. They are filled with flavor and healthgiving vitamins and furnish the best of food when fresh, canned, or dried. Pick Green-podded and Wax Beans early and often for heavy crops.

Culture. Plant about May 1 if soil is warm and dry, in rows 21 to 3 feet apart, dropping the Beans 3 inches apart in the drills and covering not more than 2 inches deep. Soil should be well prepared. Give frequent but shallow cultivation. Sow every 2 weeks for a succession.

We pay postage on pkts., lbs., 2 lbs., and 5 lbs. Larger quantities will be sent by Parcel Post if postage is included with order; otherwise they will be shipped by Express or Freight Collect. See page 2 for Parcel Post rates.

\section{Green-podded Bush Beans}

Two pounds will plant 100 feet of drill 70 pounds, an acre. A peck weighs 15 pounds, a bushel 60 pounds.

525. Bolgiano's Stringless Green-Pod. (Ready to pick in 50 days.) A superio strain producing heavy crops of long, meaty, absolutely stringless pods. Pkt.10c. lb. 35 c.; 2 lbs. 60c.; 5 lbs. $\$ 1.40$, postpaid 15 Ibs, \$3.30; 60 Ibs, \$12.00, not postpaid.

526. Boston Pea or White Navy. (Matures in 90 days.) The most popular of the socalled baking Beans. Easily grown and very productive. Pkt. 10c.; Ib. $35 \mathrm{c}$. 2 Ibs. 60 c.; 5 lbs. $\$ 1.30$, postpaid.

15 lbs. \$2.25; 60 lbs. \$7.75, not postpaid.

539. Dwarf Horticultural. (Ready to pick in 54 days.) The always stringless pods of medium length are splashed with red. Not only an excellent pod Bean but the green shelled Beans mature early and are of the finest quality. Pkt. 10c.; Ib. 35c.; 2 Ibs. 60 c.; 5 lbs. $\$ 1.30$, postpaid.

15 lbs. $\$ 3.00$; 60 lbs. $\$ 10.75$, not postpaid

546. Early Bountiful. (Ready to pick in 48 days.) An early, flat-podded Bean with rich green, stringless pods $61 / 2$ to 7 inches long. Brittle and tender, yet a splendid shipper. Pkt. 10c.; Ib. 35c.; 2 Ibs. 60c.; 5 Ibs. $\$ 1.30$, postpaid

15 lbs. $\$ 3.00 ; 60$ lbs. $\$ 10.75$, not postpaid.

549. Full Measure. (Ready to pick in 52 days.) An early, abundant producer over a long season. A stringless Bean which is a popular market variety. Pkt. 10c.; Ib. 35 c.; 2 Ibs. 60 c.; 5 Ibs. $\$ 1.40$, postpaid 15 Ibs. $\$ 3.30 ; 60$ lbs. $\$ 12.00$, not postpaid.

547. Giant Stringless. (Ready to pick in 52 days.) Very long, nearly round, straight pods of medium green. Vigorous, spreading plants. Pkt. 10c.; Ib. 35c.; 2 Ibs. 60c. 5 lbs. $\$ 1.40$, postpaid.

15 lbs. \$3.30; 60 lbs. $\$ 12.00$, not postpaid.

548. Stringless Black Valentine. (Ready to pick in 51 days.) A stringless type of the splendid Black Valentine. It is early and the hardy plant is upstanding and very prolific. Pods $61 / 2$ to 7 inches long, ovalround and filled with meaty, deliciously flavored Beans. Pkt. 10c.; Ib. 35c.; 2 Ibs. 60 c.; 5 Ibs. \$1.30, postpaid.

15 lbs. \$2.85; 60 lbs. \$10.25, not postpaid.

545. Stringless Green-Pod. (Ready to pick in 53 days.) A very early and prolific variety having long, round, fleshy, medium green pods. Desirable for the small garden because of its tender crispness and long season. Pkt. 10c.; lb. 35c.; 2 Ibs. 60c.; 5 Ibs. $\$ 1.40$, postpaid.

15 lbs. $\$ 3.30$; 60 lbs. $\$ 12.00$, not postpaid. 550. Stringless Red Valentine. (Ready to pick in 52 days.) Especially valuable for its earliness and ability to produce a crop under adverse conditions. Medium-sized pods of good color and quality. Pkt. 10c. lb. $35 \mathrm{c}$.; 2 lbs. $60 \mathrm{c}$; 5 Ibs. $\$ 1.30$, postpaid. 15 lbs. $\$ 3.00$; 60 lbs. $\$ 10.75$, not postpaid.

551. Tendergreen Beans. (Ready to pick in 53 days.) "Best-in-Garden" variety. This grand Bean produces quantities of absolutely stringless, round, meaty, tender, deep green pods, $61 / 2$ to 7 inches long. The quality and flavor is unexcelled and when canned the attractive color and delicious flavor is retained. Pkt. 10c.; Ib. 40c.; 2 Ibs. 70 c.; 5 lbs. $\$ 1.50$, postpaid.

15 lbs. $\$ 3.60 ; 60$ lbs. $\$ 13.20$, not postpaid

538. Tennessee Green-Pod. (Ready to pick in 54 days.) The intermediate early Snap Bean. Flat, dark green pods 6 to 7 inches long. Oval, flat, yellowish brown seeds. Pkt. 10c.; lb. 35c.; 2 lbs. 60c. 5 Ibs. $\$ 1.30$, postpaid

15 Ibs. $\$ 2.85 ; 60$ lbs. $\$ 10.25$, not postpaid.

\section{Edible Soy Beans}

Many varieties of edible Soy Beans have been imported from the Orient by the Department of Agriculture and detailed studies as to their adaptation to growing conditions in this country have been made. As a result, many varieties suitable for table use have been developed. They are very prolific, highly resistant to disease and insect pests; very nutritious when cooked and served similar to Lima Beans.

528. Higan. (112 days for use as green shelled Beans; full maturity for dry Beans 30 days later.) Plant medium, very erect, a heavy producer and ripens quickly at end of season. Beans at green eating stage are dark green, oval in shape; when fully matured, yellowish with brown eye; me-
dium size. Lb. $40 \mathrm{c}, ; 2$ lbs. 70 c., postpaid.

\section{Wax Beans}

541. Bolgiano's Best Yet Wax. (Ready to pick in 52 days.) "Best-in-Garden" variety. It is "Best Yet" in every way. The erect, bushy plants are diseaseresistant and really work hard producing lemon-yellow in color and oval in form, the pods are brittle and absolutely stringless. Superlative for the home-garden, the market gardener and the canner. Pkt. 10c.; lb. 40 c.; 2 lbs. 70 c.; 5 lbs. $\$ 1.50$, postpaid. 15 Ibs. $\$ 3.60$; 60 lbs. $\$ 13.20$, not postpaid. 552. Improved Golden Wax. (Ready to pick in 50 days.) Our improved strain of Golden Wax, rustproof to a remarkable degree and an early and free producer of perfectly stringless, thick, flat, yellow pods. Pkt. 10c.; lb. 35c.; 2 lbs. 60c; 5 lbs. $\$ 1.30$, postpaid.

15 Ibs. $\$ 3.00$; 60 Ibs. $\$ 10.75$, not postpaid. 542. Pencil-Pod Wax. (Ready to pick in 52 days.) A popular all-purpose variety with long, round, bright yellow pods over a long season. Pkt. 10c.; lb. 35c.; 2 Ibs. 60c.; 5 Ibs. $\$ 1.40$, postpaid

15 Ibs. $\$ 3.30 ; 60$ lbs. $\$ 12.00$, not postpaid. 540. Sure-Crop Stringless Wax. (Ready to pick in 53 days.) Pods are 6 to 7 inches long, flat, tender and of fine flavor. A fine late variety. Pkt. 10c.; Ib. 35c.; 2 Ibs. 60c.; 5 Ibs. $\$ 1.30$, postpaid.

15 lbs. \$3.00; 60 lbs. \$10.75, not postpaid.

\section{Climbing or Pole Beans \\ One pound will plant 100 hills;}

543. Cherry Pole, Horticultural, or Cutshort. (Ready to pick in 75 davs.) The short pale green pods are streaked with red and the Beans are splashed and spotted with wine-red. The Beans are of the highest quality either green or dry. Pkt. $10 \mathrm{c}$. $15 \mathrm{lbs}, \$ 3.00 .60 \mathrm{lbs} \$ 10.75$, not postpaid.

530. Golden Cluster Wax. (Ready to pick in 74 days.) An extra-strong grower and very productive one. The golden yellow and of excellent flavor. The dry Beans ar pure white. Pkt. 10c;
5 lbs. $\$ 1.40$, postpaid.

15 lbs. \$3.30; 60 lbs. $\$ 12.00$, not postpaid. 553. Kentucky Wonder or Old Homestead. (Ready to pick in 65 days.) One stert and most product green-podded varietres. Silvery green, ters from base to top of the pole. These Beans cook deliciously tender. Pkt. 10c. 15 Ibs. $\$ 3.00$; 60 lbs. $\$ 10.75$, not postpaid.

\section{Lazy Wife. (Ready to pick in 74 days}

and green shelled or dry Beans. The broad, thick, stringless pods are 5 to 7 inches long. Ib. $35 \mathrm{c}$.; 2 Ibs. $60 \mathrm{c}$.; 5 lbs. $\$ 1.30$, postpaid. 15 Ibs. $\$ 3.00$; 60 Ibs. $\$ 10.75$, not postpaid.

569. White Creaseback or Cornfield. (Ready to pick in 65 days.) One of the and dry Beans. The crease-backed pods are stringless when young and the dry Beans are small and ivory-white. Pkt, 10c; Ib. $35 \mathrm{c}$; 2 lbs. 60 c.; 5 lbs. $\$ 1.30$, postpaid. 15 lbs. $\$ 3.00$; 60 lbs. $\$ 10.75$, not postpaid.

\section{EVER GREEN GARDEN SPRAY}

\section{Pyrethrum Rotenone Insecticide}

A non-poisonous contact insecticide. Kills rose chafers, bean beetles, cutworms, aphis, slugs, and other pests.

Oz. 35 c.; 6 ozs. $\$ 1.00 ; 16$ ozs. $\$ 2.15$; gal. $\$ 12.20$.

\section{Bolgiano's Vegetable Garden Collection COMPOSED ENTIRELY OF "BEST-IN-GARDEN" VARIETIES}

This Collection covers the most popular kind of vegetables used in every home, gives you the best varieties to order and saves you time and money. As these Collections are set up in advance, we cannot make any change in varieties or quantities.

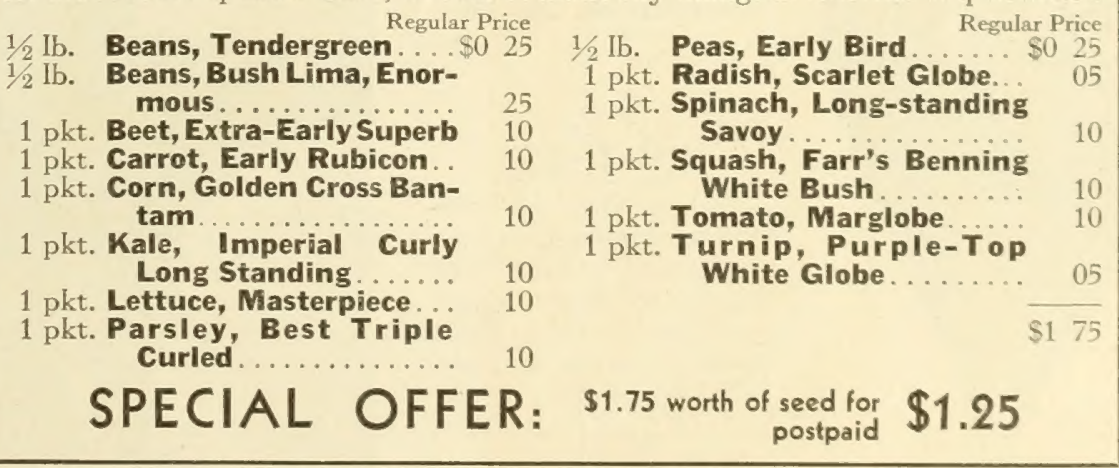


We pay postage on pkts., lbs., $2 \mathrm{lbs}$, and $5 \mathrm{lbs}$. Larger quantities will be sent by Parcel Post if postage is included with order; otherwise they will be shipped by Express or Freight Collect. See page 2 for Parcel Post rates.

\section{LIMA BEANS}

Culture. Limas do best in a rich, welldrained, sandy soil and should not be planted until the ground is dry and warm. Plant the seeds edgewise, with the eye down, and cover with about 2 inches of soil.

\section{Bush Lima Beans}

One pound will plant a 100 -foot row; 60 pounds, an acre

Culture. Plant Bush Limas in rows 3 feet apart, placing 2 or 3 Beans 12 to 15 inches apart in the row

500. Baby Fordhook. (Ready to pick in 70 days.) The bushy plants carry surprising crops of small pods each containing 3 or 4 meaty green Beans which turn creamIbs. 60 c.; 5 lbs. $\$ 1.40$, postpaid.

15 lbs. $\$ 3.30$; 60 lbs. $\$ 12.00$, not postpaid. 504. Bolgiano's Enormous. (Ready to pick in 75 days.) "Best-in-Garden" riety. A truly wonderful sort, being very early and its vigorous bushes crowd themselves with enormous pods continuously from June until frost. Large thick pods are frlled with lusciously flavored thick Beans. We are sure you will be pleased. Pkt. 10c. Ib. $40 \mathrm{c}$; 2 Ibs. $70 \mathrm{c}$; 5 l'ss. $\$ 1.50$, postpaid. 15 lbs. \$3.60; 60 lbs. $\$ 13.20$, not postpaid

506. Dreer's. (Ready to pick in 80 days.) Pkt. 10c.; [b. 35c.; 2 lbs. 60c.; 5 lbs. \$1.30, postpaid.

15 lbs. \$3.00; 60 lbs. $\$ 10.75$, not postpaid.

512. Fordhook. (Ready to pick in 75 days, Its strong, erect plants hold their clusters of large pods well above the ground. The pods are filled with thick meaty Beans which retain their green tint when dried. Pkt. 10c.; Ib. 40c.; 2 Ibs. 70c.; 5 Ibs. $\$ 1.50$ postpaif.

15 lbs. $\$ 3.60 ; 60$ lbs. $\$ 13.20$, not postpaid. 505. Henderson's. (Ready to pick in 65 days.) A popular home-garden variety, very early and very productive. Pkt. 10c. lb. 35c.; 2 Ibs. 60 c.; 5 lbs. $\$ 1.30$, postpaid. 15 lbs. $\$ 2.85 ; 60$ Ibs. $\$ 10.25$, not postpaid. 513. Improved Large. (Ready to pick in 75 days.) Large pods well filled with large thick Beans of excellent flavor. Pkt. 10c.; Ib. 40c.; 2 Jbs. 70 c.; 5 Ibs. $\$ 1.50$, postpaid. 15 Ibs. $\$ 3.45$; 60 lbs. $\$ 12.60$, not postpaid. 501. Wood's Prolific. (Ready to pick in 65 days.) Pkt. 10c; ; lb. 35c.; 2 Ibs. 60c.; 5 Ibs. $\$ 1.30$, postpaid.

15 libs. \$3.15; 60 lbs. $\$ 11.40$, not postpaid

\section{Pole Lima Beans}

One pound will plant 50 hills; 45 pounds an acre

Culture. Plant 4 to 6 Beans in each hill and thin to the 3 best plants.

503. Bolgiano's Emerald Isle. (Ready to pick in 85 days.) You would really enjoy growing Emerald Isle just for its mammoth pods which are often over 7 inches long and $11 / 2$ inches wide, but in addition to its size it is early and is a heavy yielder of fine-flavored Beans. Pkt. 10c.; lb. 35c.; 2 lbs. 60 c.; 5 Ibs. $\$ 1.40$, postpaid.

$15 \mathrm{lbs} . \$ 3.30 ; 60$ lbs. $\$ 12.00$, not postpaid.

517. Bolgiano's Evergreen. (Ready pick in 85 days.) "Best-in-Garden" variety. Clusters of large pods hang all over the vine and are filled with the most delicious Beans which are so tender they cuok quickly. Pkt. 10c.; lb. 40c.; 2 lbs. 70c.; 5 lbs. $\$ 1.50$, postpaid.

15 lbs. $\$ 3.45 ; 60$ lbs. $\$ 12.60$, not postpaid

509. Carolina or Sieva. (Ready to pick in 78 days.) Familiarly known in the South as the "Butter Bean," it is a very early and productive variety. The small Beans are white and of good flavor. Pkt. 10c.; Ib. 35c.; 2 lbs. $60 \mathrm{c}$.; 5 Ibs. $\$ 1.30$, postpaid.

15 lbs. $\$ 3.00$; 60 lbs. $\$ 10.75$, not postpaid.
502. Carpinteria. Ready to pick in 85 days.) A good producer of 5 to 6 -inch pods usually containing 4 large, very thick Beans of fine quality which have a distinctive greentsh timt.

15 lbs. \$3.15; 60 lbs. \$11.40, not postpaid.

516. King of the Garden. (Ready to pick in 85 days.) Luxurious growth produces large pods filled with 5 or 6 perfect Beans of uscious quality which retain their green color when dry. Pkt. 10c. Ib. 35c; 2 tbs. 60 c.; 5 lbs. $\$ 1.30$, postpaid.

15 Ibs. $\$ 3.15 ; 60$ lbs. $\$ 11.40$, not postpaid.

508. Potato or Improved Challenger. (Ready to pick in 78 days,) So named because the Beans are of a similar shape and size as those of Fordhook Bush Lima. Pkt. 10c.; Ib.

15 lbs. $\$ 3.00$; 60 lbs. $\$ 10.75$, not postpaid.

\section{BEETS}

One ounce will sow 50 feet of drill; 6 to 7 pounds, an acre

Prices include postage on pkts., ozs., 1/4lbs., and lbs.

Beet tops have unusually high food value, being rich in vitamins $A$ and $C$ and rank high as suppliers of calcium and iron. Save
all your Beet tops, especially the little ones pulled out in thinning; they make delicious cooked "greens."

Culture. Beets do best in fairly light, tivated during the season. Sow in drills 1 foot apart and 1 inch deep, as early as the ground can be worked, and for a succession Continue sowing up to the middle of August. apart.

Late Beets can be kept for winter use by packing the roots in slightly moist earth in a cool cellar.

108. Bolgiano's Early Eclipse. (55 days.) Remarkable for its rapid growth, perfect flesh and medium foliage. Roots are bright glossy red and very fine-grained. Pkt. 10c.;

67. Bolgiano's Extra-Early Superb.

days.) "Best-in-Garden" variety. Superior merit has placed this in the lead of all early turnip-shaped Beets. It is very early. The shape is uniformly perfect and is free from fibrous side-roots. It is the smoothest Beet we have ever seen. Its rich, dark blood-red flesh is tender, crisp and deliciously sweet. Its small top makes it ideal for bunching. It is excellent for forcing or to grow for the main crop.
Pkt. 10c.; oz. 20c.; $1 / 1 \mathrm{lb}$. 50c.; lb. $\$ 1.75$, postpaid.

125. Crosby's Extra Early. (50 days.) Superior strain of Egyptian with deep blood-red flesh. Roots are slightly flattened globes with small tap-roots. The larger tops are in demand for "greens." 1/ lb. 50c.; Ib. $\$ 1.75$, postpaid.

103. Detroit Dark Red. (60 days.) A standard dark red turnip-shaped Beet. The stand up well.

Pkt. 10c.; oz. 25c.; 1/4t Ib. 65c.; Ib. \$2.25, postpaid.

127. Early Blood Turnip. (55 days.) Bright red, medium early Beet of very good quality. Popular for home or garden $\$ 1.75$, postpaid

45. Early Wonder. (52 days.) Its extraearly maturity, small tap-root, small tops, deep red color and frne-grained flesh make this a winner in the early market. Successful in hotbeds, coldframes or open ground, Pkt. 10c.; oz. 20c.; 1/4lb. 50c.; lb. $\$ 1.75$, postpaid.
68. Long Smooth Blood.

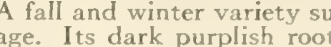

age. Its dark purplish roots$$
\text { postpaid }
$$

142. Pink Crosby

Il-season, light pink Bet An excellent,

or under glass. Perfectly smooth roots

desirable shape. Scant foliage. Pkt. 10c.

\section{Mangel-Wurzel}

For Cattle Feed

Sow 5 pounds to acre

Matures in 90 to 110 days

49. Giant. The heaviest cropper. Mam-

moth roots of fine quality. Oz. 15c.; $1 / 4 \mathrm{lb}$.
$45 \mathrm{c}$; Ib. $\$ 1.50 ; 2$ lbs. $\$ 2.75 ; 5$ lbs. $\$ 6.75$,

postpaid.

53. Golden Tankard. A Iarge Mangel with yellow-fleshed roots. Splendid milk-

2 lbs. $\$ 2.75 ; 5$ Ibs. $\$ 6.75$, postpaid.

97. Improved Sugar Beet. Large

$\mathrm{O}_{z}$ 15c. 1 ib $45 \mathrm{c}$. Ib $\$ 1.50$; 2 lbs. $\$ 2.75$;

Ibs. $\$ 6.75$, postpaid.

204. New Jumbo. This new Beet is en-

joyed by cattle and is a real milk-producer.

5 Ibs. $\$ 6.75$, postpaid.

\section{Swiss Chard}

\section{Spinach Beet}

One ounce will sow 60 feet of row

Prices include postage on pkts., ozs. $1 / 4 \mathrm{lbs}$., and $\mathrm{lbs}$.

Chard is high in vitamin A and is a reliable source of iron.

Culture. Sow the seeds about an inch apart in the row, covering with an inch of 8 to 10 inches apart in the row. The plants will furnish "greens" all summer and fall. If plants are protected over winter they will furnish early "greens" before the new crop is ready.

214. Fordhook Giant. (60 days.) Wide, heavily crumpled leaves of dark green oz. 20c, $1 / 4$ lo. 50c, lb, $\$ 1.75$, postpaid.

145. Lucullus. ( 60 days.) Plants grow $11 / 2$ to 2 feet tall with many creamy white,
curled leaves carried on broad thick stalks.

Pkt. 10c.; oz. 20c.; 1/4 lb. 50c.; lb. $\$ 1.75$, postpaid.

\section{BROCCOLI}

One ounce will produce 2500 to 3000 plants Prices include postage on pkts., ozs., and Ibs.

Broccoli is an excellent source of vitamins $A$ and $C$ and supplies both calcium and iron.

Culture. Start seed in hotbeds in early spring or sow in garden when soil is in condition to work. Transplant to open ground when plants are six weeks old, setting them 2 feet apart in row

235. Italian Green Calabrese or Italian Green Sprouting. (75 days.) "Best-inGarden" variety. This Broccoli makes a tall branching plant with a central head of bluish green buds, and after this central head is cut each branch forms a smaller head so that there is continuous production for 8 to 10 weeks. This is a delicious vegetable becoming more popular every year. Pkt. 10c; oz. $45 \mathrm{c}$; ; $1 / 4 \mathrm{lb}$. \$1.10;

168. Salad Broccoli. Yields an abundance of excellent salad "greens." Pkt. 10c. 


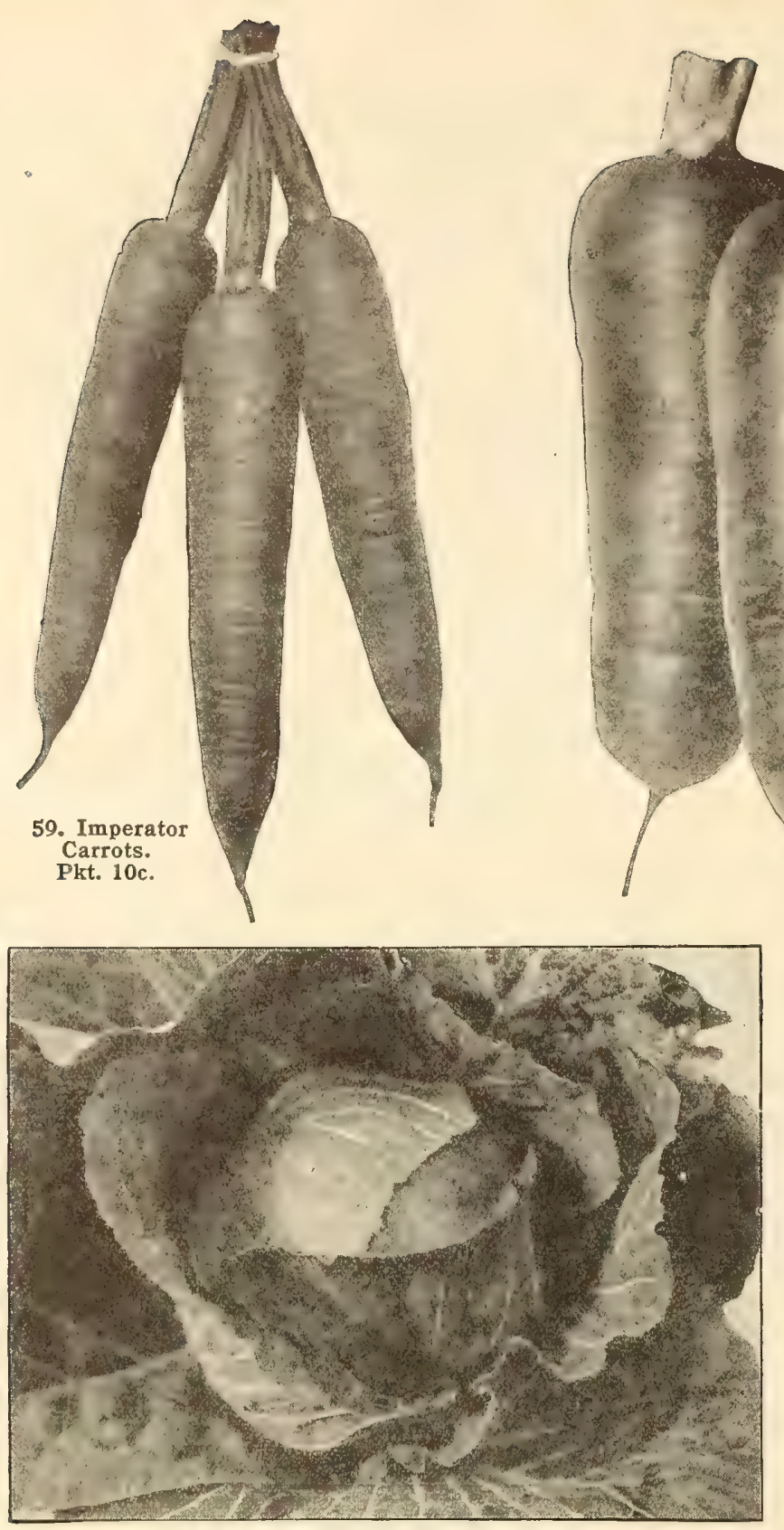

89. Late Flat Dutch Cabbage. Pkt. 5c.

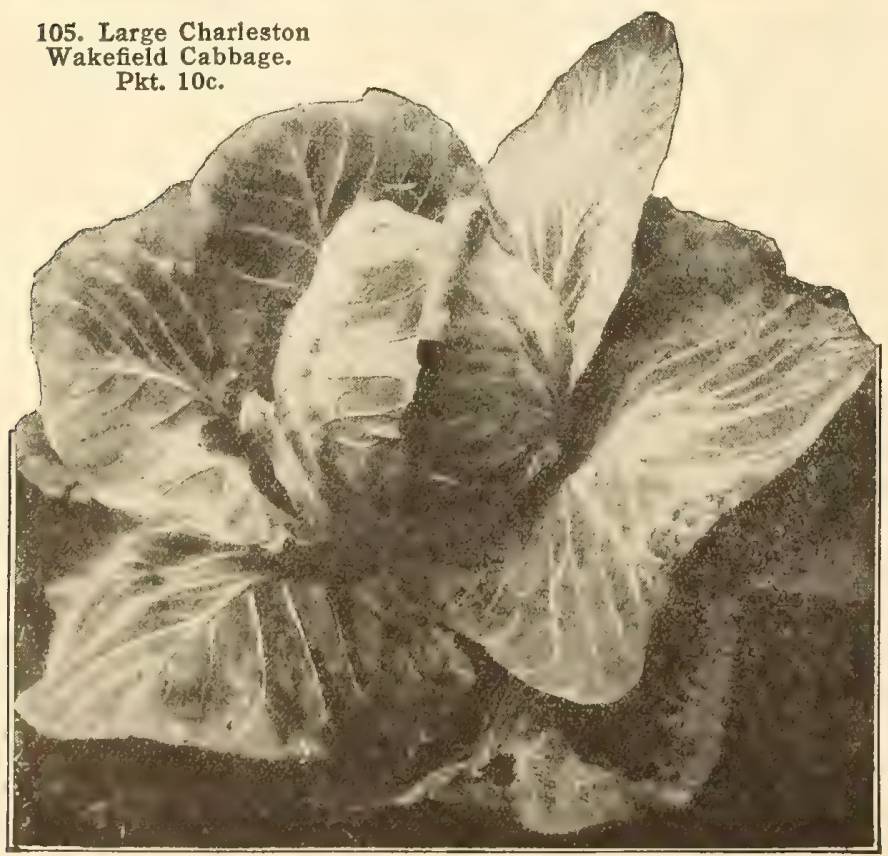

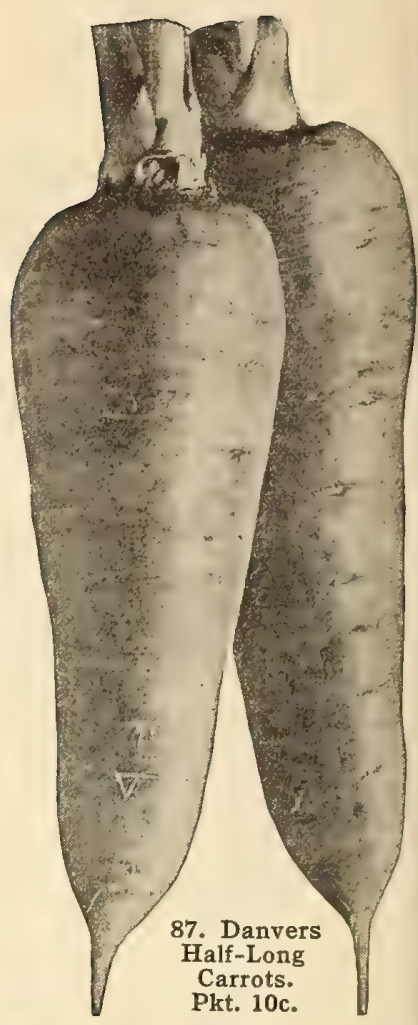

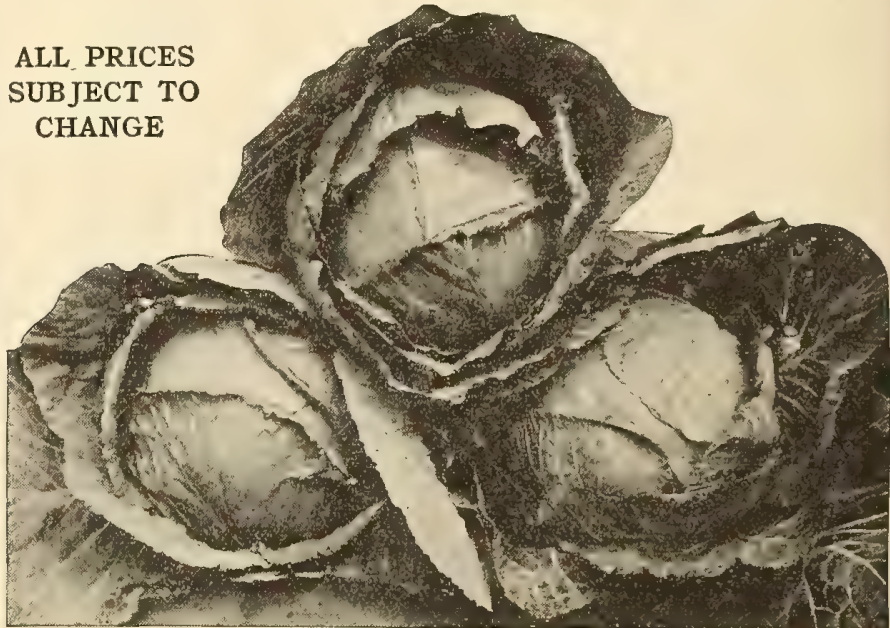

117. Bolgiano's New Early Cabbage. Pht. 10c.

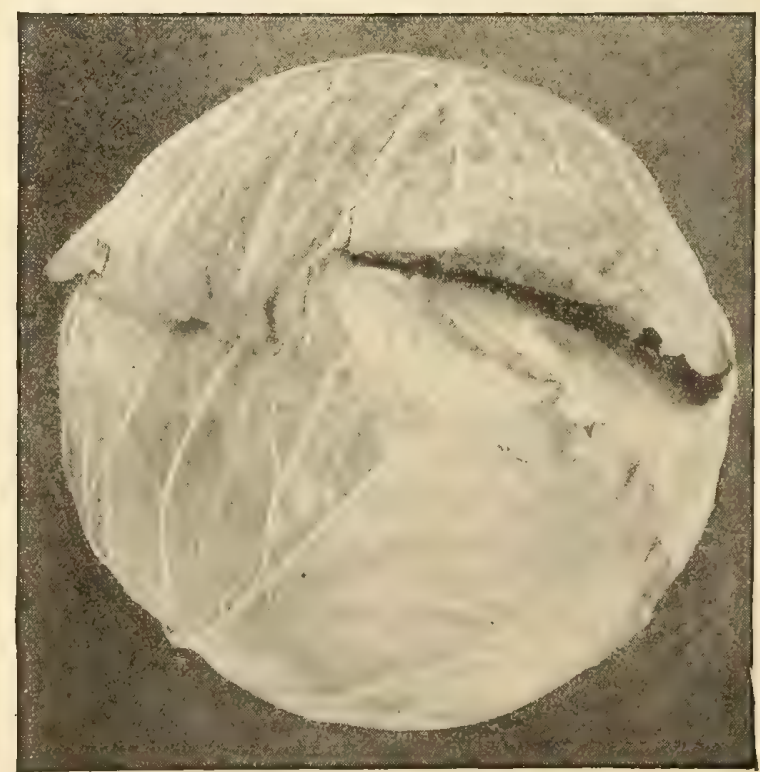

312. Marion Market Cabbage. Pkt. 10c. 


\section{BRUSSELS SPROUTS}

One ounce will produce about 2500 plants Prices include postage on pkts., ozs., $1 / 4 \mathrm{lbs}$, and $1 \mathrm{bs}$.

Brussels Sprouts are high in vitamin $C$ and have some vitamin $A$.

Culture. The plants are very hardy and may remain outdoors in many locations during the winter. Frost improves both quality and flavor of the vegetable. Handle seed and small plants like late cabbage.

290. Perfection. (90 days.) The stalks grow about 2 feet tall and produce from Pkt. 10c.; oz. 65c.; 1/4lb. $\$ 2.00$, postpaid.

\section{CABBAGE}

One ounce will produce 2000 to 2500 plants: $1 / 4$ pound should plant an acre

Prices include postage on pkts., ozs., $1 / 41 \mathrm{bs}$., and lbs.

Cabbage is especially valuable for its vitamin $C$.

Culture. Cabbage does best in fresh, rich, well-manured soil deeply prepared. For very early use sow in January or February in hotbeds, transplanting to other hotbeds when ready, or sow in coldframes in March. Transplant, when frost-danger has passed, to open ground, $11 / 2$ to 2 feet apart in the row.

Later crops can be sown outside from late March until early May, in drills from transplanting, or better, sow in the freld-rows, thinning out instead of transplanting. Days listed are from setting of plants.

\section{Extra-Early Varieties}

122. Big Winner Wakefield. (68 days.) Like all the Wakefrelds, the head is conical with a blunt point but it is Iarger and of better quality. Pkt. 10c.; oz. $40 \mathrm{c}$; $1 / 4 \mathrm{Ib}$ $\$ 1.00$; Ib. $\$ 3.50$, postpaid.

128. Bolgiano's Early York. (65 days.) Valuable for its earliness and the round, very frrm, heart-shaped heads. Pkt. 10c. oz. 35c.; $1 / 4 \mathrm{Ib}$. $90 \mathrm{c}$; Ib. $\$ 3.25$, postpaid.

229. Dark Green Copenhagen. (66 days.) The intense green color gives the heads fresh appearance even after shipping. Pkt. 10 c.; oz. 50 c.; $1 / 4$ Ib. $\$ 1.40$; Ib. $\$ 5.00$, postpaid

233. Early Round Dutch. (70 days.) Produces small compact plants; stem short; heads medium dark green; average 4 to 5 pounds. Pkt. $10 \mathrm{c}$; $0 \mathrm{oz}, 30 \mathrm{c}$; $1 / 4 \mathrm{Ib}, 85 \mathrm{c}$. Ib. $\$ 3.00$, postpaid.

299. Golden Acre. (65 days.) A Copenhagen type with smaller solid round heads maturing 7 to 10 days earlier than Copenhagen Market. Pkt. $10 \mathrm{c}$; oz. $40 \mathrm{c}$; $1 / 4 \mathrm{lb}$. $\$ 1.15$; Ib. $\$ 4.25$, postpaid.

80. Jersey Wakefield. Selected Stock. $(65$ days.) The most popular early pointedhead Cabbage. Our selected stock has medium-sized solid heads with few outer leaves. Heads all mature at one time, an important feature when the land is wanted for another crop. Pkt. 10c.; oz. 30c.; $1 / 4$ lb. 85 c.; Ib. $\$ 3.00$, postpaid.

\section{Early Varieties}

129. Allhead Early. (78 days.) "This earliest of the large-heading Cabbages produces remarkably solid, flat heads 6 to 7 inches deep. They are uniform in color, form and size. A good winter keeper. Pkt. 10 c.; oz. 30c.; $1 / 4 \mathrm{Ib} .85$ c.; Ib. $\$ 3.00$, postpaid.

117. Bolgiano's New Early. (75 days.) "Best-in-Garden" variety. Sheer merit has placed this at the top of the Cabbages. Maturing a few days after the earliest varieties, it excels other market sorts in production and quality. The immense hearts develop rapidly and have few outer spreading leaves, thus allowing close planting and increasing pounds produced per acre. Pkt. 10c.; oz. 30c.; 1/4Ib. 85c.; lb. $\$ 3.00$, postpaid.
333. Copenhagen Market. (70 days.) A dependable market variety maturing highquality heads averaging $31 / 2$ to 4 pounds each. Pkt. 10c:;

94. Globe, Yellows-Resistant. (80 days.) A yellows-resistant strain of Glory of Enkhuizen. Pkt. 10

Ib. $\$ 4.50$, postpaid.

319. Glory of Enkhuizen. (78 days.) A great kraut Cabbage, also popular with shippers. It is a sure header with globeshaped, solid heads of gray-green color.

Pkt. 10c.; oz. 35c.; 1/4 Ib. $\$ 1.15$; lb. $\$ 4.00$,

105. Large Charleston Wakefield. (72 days.) This matures about 5 to 10 days later than Jersey Wakefield and produces heads so Iarge that they should be planted 20 inches apart in the row. Heads are Pkt. 10c.; oz. 30c.; 1/4 Ib. 85c.; Ib. $\$ 3.00$, postpaid.

312. Marion Market. Yellows-Resistant. (78 days.) A yellows-resistant strain of Copenhagen Market with the parent's round head and crisp tenderness. Succeed Pkt. $10 \mathrm{c}$; oz. $40 \mathrm{c}$; ; 1/4 Ib. $\$ 1.25$; Ib. $\$ 4.50$,

113. Succession. (85 days.) Splendid for late summer and fall use; good keeper. Stem short; heads Iarge and flat. Average 7 to 8 pounds. Pkt. $10 \mathrm{c}$; oz. $30 \mathrm{c}$; $1 / 4$ Ib. $85 \mathrm{c}$.

336. Wisconsin Allhead Select. YellowsResistant. (85 days.) A yellows-resistant strain of the frne Allhead Early. Pkt. 10c oz. 40 c.; $1 / 4$ Ib. $\$ 1.25$; Ib. $\$ 4.50$, postpaid.

\section{Late Varieties}

89. Late Flat Dutch. (110 days.) An old favorite with truck gardeners who appreciate its large size, solidity, uniformity and good keeping qualities. Pkt.
oz. 30 c.; $1 / 4$ Ib. 85 c.; Ib. $\$ 3.00$, postpaid.

281. Round Red Dutch. (95 days.) Best market variety. Very solid heads of deep purplish red. Pkt. 10c.; oz. 50c.; $1 / 4 \mathrm{lb}$. $\$ 1.40 ;$ Ib. $\$ 5.00$, postpaid.

124. Perfection Drumhead Savoy. $(90$ days.) The best Savoy Cabbage for general use. Heads are nearly round, full and hard, with dark green crimped leaves. Pkt. 10c.; oz. 40c.; 1/4 Ib. $\$ 1.25$; Ib. $\$ 4.50$, postpaid.

315. Wisconsin All-Season. Yellows-Resistant. (90 days.) A drumhead in shape on short stems. It is resistant to yellows, drought and mosaic. Pkt. 10c.; oz. 35c.; $1 / 4 \mathrm{Ib} . \$ 1.15$; Ib. $\$ 4.00$, postpaid.

314. Wisconsin Batthead. Yellows-Resistant. (95 days.) A yellows-resistant strain with uniform, very hard, ball-shaped heads. Short stems and blue-green leaves. Pkt. 10c.; oz. 50c.; 1/4lb. $\$ 1.40$; lb. $\$ 5.00$, postpaid.

\section{Frostproof Cabbage Plants} WILL DOUBLE YOUR PROFITS

Ready for Immediate Delivery

Matures Heads Two to Three Weeks Earlier Than Your Home-grown Plants

Our plants are grown in the South where are found soil and climatic conditions just suited for growing tough, hardy Cabbage plants during the winter and early spring. are ready for shipment at 8 to 10 weeks of age. They are then very tough and hardy and can be planted in the open ground a month to six weeks sooner than the more delicate hotbed or coldframe plants.

When spring comes the plants grow very fast, maturing headed Cabbage 2 to 3 weeks sooner than from hotbed or coldframe plants. Think what the difference in profit will be if your crop is matured and marketed before the general crop from home plants is matured!

\section{Early Jersey Wakefield}

Charleston Large-Type Wakefield Allhead Early Copenhagen Markel

Prices by Parcel Post, postage prepaid: 100 to 400 plants at $60 \mathrm{c}$. per $100 ; 500, \$ 2.00$; 1000 or more, $\$ 3.00$ per 1000 plants.

Prices by Express, buyer paying charges: 1000 to 4000 at $\$ 1.50$ per 1000 plants; 5000 to 8000 at $\$ 1.40$ per 1000 . Plants are packed for Parcel Post shipment-100, 200, 300, 400, 500 or 1000 plants to the package. For Express shipment: 1000 or 2000 plants to the package. Order only in these quantities. We pack only one variety to the package. They weigh about 20 pounds per thousand plants, packed for shipment.

TERMS: Cash with order. No plants shipped C.O.D.

\section{Chinese or Celery Cabbage}

\section{A Chinese vegetable which is becomin} more and more popular, finding a ready sale
in city markets. Heads are easily blanched and may be used as a salad or boiled like must be gatherec

141. Chihili.

heads 18 to 20 inches long and $31 / 2$ to 4 inches through. Pkt. 10 .

216. Pe-Tsai.

somewhat tapering hea A delicious crisp, sweet vegetable. Pkt. $10 \mathrm{c}$. oz. 25 c.; $1 / 4$ Ib. 75 c.; Ib. $\$ 2.50$, postpaid.

\section{CARROTS}

One ounce will sow 100 feet of row; 3 to 4 pounds, an acre

Prices include postage on pkts., ozs., $1 / 4 \mathrm{lbs}$, and $\mathrm{lbs}$.

Carrots are one of the best sources of the important vitamin A and provide a fair supply of vitamin C. Eat plenty of Carrots. Culture. Carrots do best in rich, sandy loam well pulverized and kept deeply cultivated. Sow seed thinly in rows and cover Sow as early as ground is workable and at periods up to July for Iatest crop. Thin out to 4 inches apart. Keep well cultivated.

48. Chantenay or Model. (72 days.) A broad stump-rooted Carrot 5 inches long and $2 \frac{1}{4}$ inches through at shoulder. The roots are smooth; deep orange flesh is frne-
grained and tender. Pkt. $10 \mathrm{c}_{.} ; 0 z .40 \mathrm{c}$. $1 / 4$ lb. $\$ 1.00$; Ib. $\$ 3.50$, postpaid.

87. Danvers Half-Long Orange Pointed. (75 days.) Large, cylindrical, smooth Carrot of dark orange. The flesh is close soils and is one of the heaviest producers grown. Pkt. 10c.; 0z. 40c.; $1 / 4 \mathrm{Ib}$. $\$ 1.00$; Ib. $\$ 3.50$, postpaid.

134. Early Rubicon. (72 days.) "Best-inGarden" variety. A half-long, stumprooted Carrot of deep red-orange. Earlier than Danvers, its heavier, thicker shoulder makes it a wonderfully heavy cropper, good culture. Pkt. $10 \mathrm{c}$; oz. $40 \mathrm{c}$; $1 / 4 \mathrm{lb}$. $\$ 1.00$; Ib. $\$ 3.50$, postpaid.

161. Half-Long Stump-rooted Nantes. (68 days.) This Carrot measures about 6 inches long by $11 / 2$ inches in diameter. Tops are small and the rich orange flesh is tender and sweet. Pkt. $10 \mathrm{c}$; oz. $40 \mathrm{c}$.; $1 / 4 \mathrm{lb} . \$ 1.15$; lb. $\$ 4.00$, postpaid.

59. Imperator. (75 days.) An ideal Carrot for market growers and shippers. Strong tops bunch well. The tapering roots are 7 to 8 inches long with rich orange flesh, mild and sweet and nearly coreless. Pkt $10 \mathrm{c}$; oz. $40 \mathrm{c}$; $1 / 4 \mathrm{Ib}$. $\$ 1.15 ; 1 \mathrm{~b} . \$ 4.00$, postpaid. 


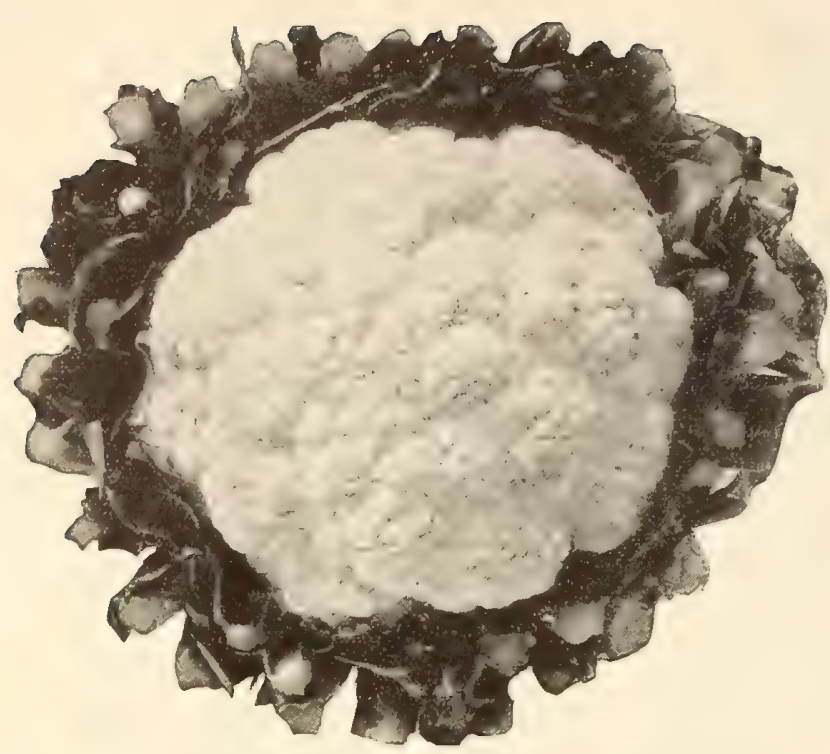

273. Early Snowball Cauliflower. Pkt. 25c.

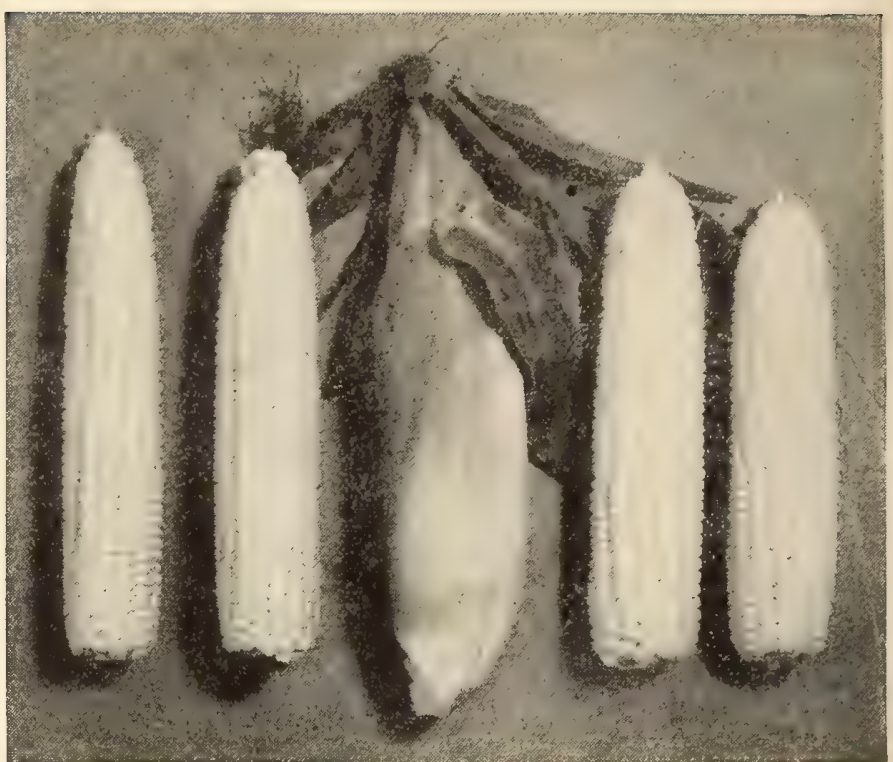

534. Ioana Hybrid Sweet Corn. Pkt. 10c
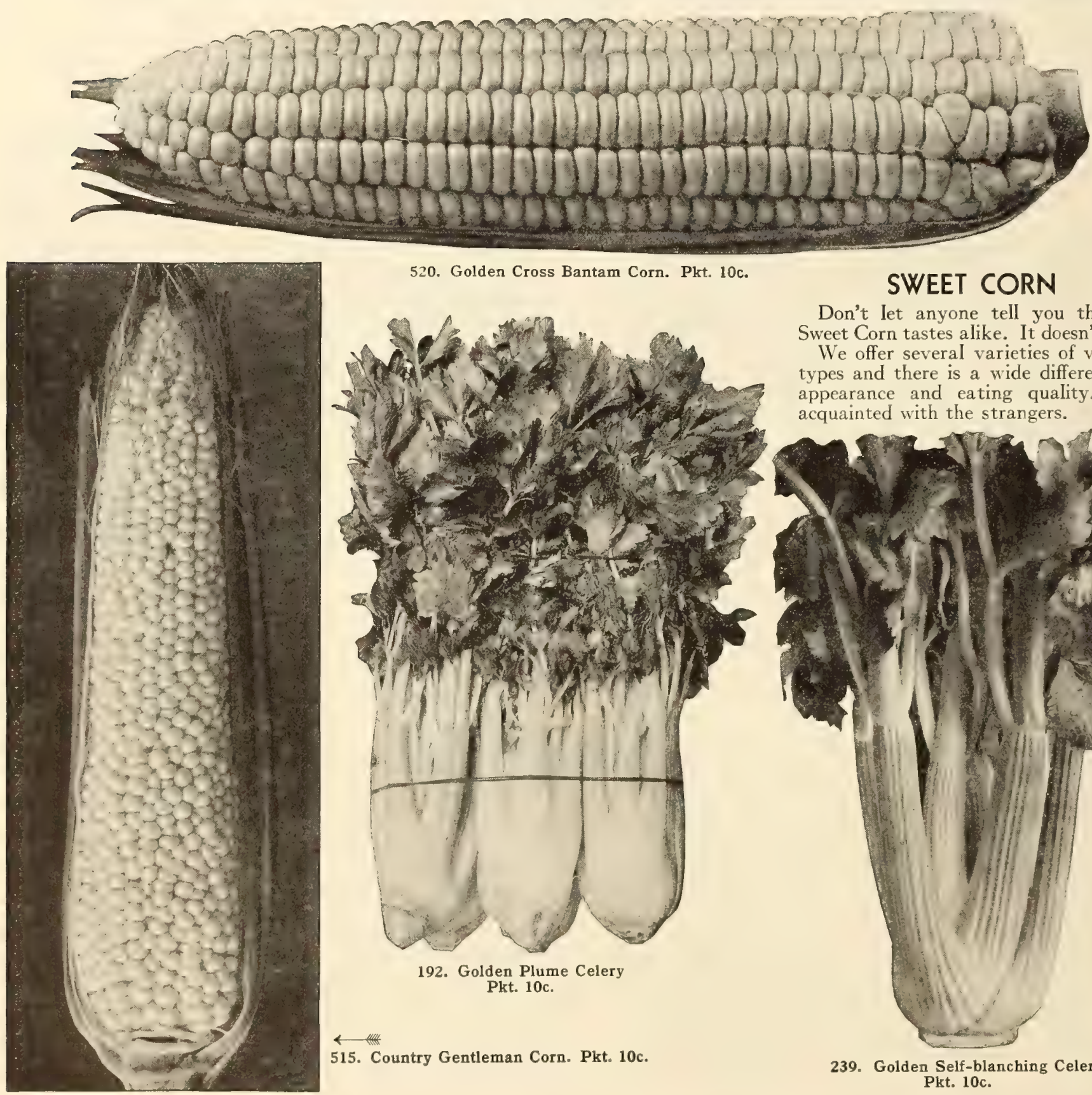

520. Golden Cross Bantam Corn. Pkt. 10c.

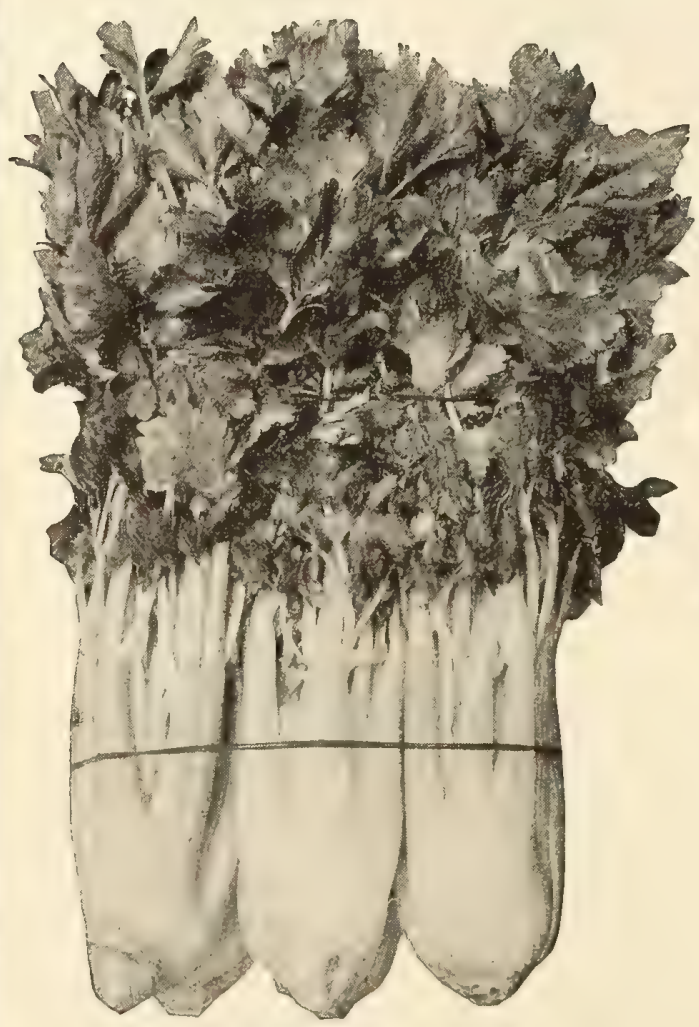

192. Golden Plume Celery Pkt. 10c.

515. Country Gentleman Corn. Pkt. 10c.

\section{SWEET CORN}

Don't let anyone tell you that all Sweet Corn tastes alike. It doesn't.

We offer several varieties of various types and there is a wide difference in appearance and eating quality. Get acquainted with the strangers.

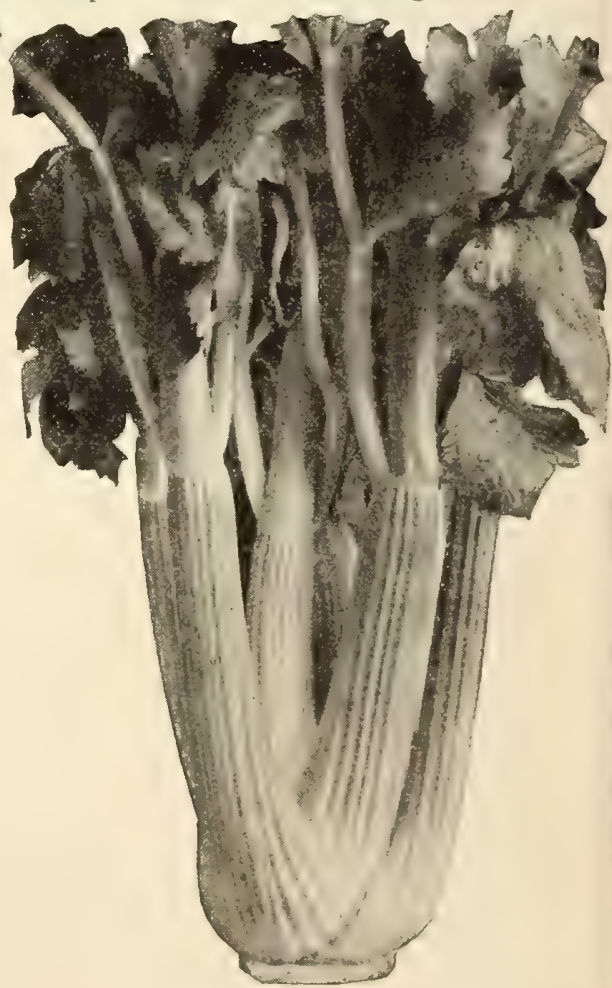

239. Golden Self-blanching Celery Pkt. 10c. 
CARROTS, continued

100. Nichol's Long Orange Improved. (85 days.) A heavy yielder and good keeper. Roots up to 12 inches long and 3 inches in diameter at top. Tender, sweet flesh makes it a desirable table Carrot. Pkt. 10c.; oz. 40c.; 1/4lb. $\$ 1.00$; lb. $\$ 3.50$, postpaid.

222. Oxheart Selected Stock. (75 days.) A thick-shouldered, blunt-tipped Carrot which grows rapidly to 5 inches long and often weighs more than a pound. The orange-red flesh is tender. Fkt. 10c.; oz. $40 \mathrm{c}$; $1 / 1 \mathrm{lb}$. $\$ 1.00 ; \mathrm{lb} . \$ 3.50$, postpaid.

338. Red-Core Chantenay. ( 70 days.) This tender, sweet Carrot is reddish orange all the way through. There is no yellow core to spoil the looks when it is sliced. Pkt. $10 \mathrm{c}$; oz.40c.; $1 / 4$ lb. $\$ 1.00$; Ib. $\$ 3.50$, postpaid.

\section{CAULIFLOWER}

One ounce will produce about 2000 plants.

Prices include postage on pkts. ozs., and $1 / 4 \mathrm{lbs}$.

Cauliflower is valuable for its vitamin C

Curture. Same as Cabbage. When heads are about 2 inches in diameter tie up the outer leaves to blanch the head.

289. Autumn Giant. (130 days.) While heads are not as tightly formed as earlier varieties they remain fit for use longer.

Pkt. 25c; 1/40z. 90c.; 1/oz. \$1.50; oz. \$2.50; $1 / 4 \mathrm{lb} . \$ 8.00$, postpaid.

273. Early Snowball. (90 days.) "Best-inGarden" variety. This best known of all Cauliflowers may be planted early in spring or late in fall. The dwarf plants with their pale green leaves form a perfect background for the large, solid, pure white heads which are of excellent quality

Pkt. 25c.; 1/4oz. \$1.00; 1/20z. \$1.75; oz. $\$ 3.00 ; 1 / 1$ lb. $\$ 10.00$, postpaid

334. Extra-Early Dwarf Erfurt. (90 days.) Medium-sized snow-white heads with deep curd are developed on dwarf, shortstemmed plants. Pkt. 25c.; 1/4 oz. \$1.00; 1/oz $\$ 1.75 ; 0 z, \$ 3.00 ; 1 / 4$ lb. $\$ 10.00$, postpaid.

252. The Twentieth Century. ( 90 days.) Large, compact heads of snow-white. Pkt. $25 \mathrm{c}$; $1 / 4$ oz. $\$ 1.00$; $1 / 2$ oz. $\$ 1.75$; oz. $\$ 3.00$; $1 / 4 \mathrm{lb} . \$ 10.00$, postpaid.

\section{CELERY}

One ounce will produce about 5000 plants; $1 / 8$ ounce will sow 100 feet of row; $1 / 4 \mathrm{lb}$. will plant an acre.

Prices include postage on pkts., ozs., $1 / 4 \mathrm{lbs}$, and lbs.

Curture. Sow from late March through April in rich mellow ground in shallow drills and keep well watered. Celery seed germinates in about two weeks if the soil is kept always moist. Transplant when the seedlings are 5 to 6 inches tall to stand 5 to 6 inches apart in the row. Keep well cultivated and blanch by earthing up when plants are large enough. Days to maturity of Celery varies considerably; we give approximate days.

308. Easy Blanching. (115 days.) A splendid second-early variety, dwarf and compact in habit with light green foliage. The stalks blanch easily to pure white and are heavy, crisp and of good flavor. Pkt. 10c.; oz. 50c.; Ib. $\$ 1.40$; Ib. $\$ 5.00$, postpaid. 264. Giant Pascal. (135 days.) A stronggrowing Celery with dark green leaves and large thick stalks which blanch easily. They are solid and crisp with a rich nutty flavor. Pkt. 10c.; oz. 50c.; 1/4lb. \$1.40; Ib. $\$ 5.00$, postpaid.

192. Golden Plume or Wonderful. (110 days.) "Best-in-Garden" variety. Attractive in appearance, it produces attractive full hearts of golden yellow. These are delightfully crisp, free from strings and have a rich nutty flavor. The plants are resistant to blight and rot. Pkt. $10 \mathrm{c} ; 0 \mathrm{z} .50 \mathrm{c}$; $1 / 4 \mathrm{Ib}$. $\$ 1.65 ; \mathrm{Ib}$. $\$ 6.00$, postpaid.
239. Golden Self-blanching. Bolgiano's Special Strain. (115 days.) Growth is vigorous and compact with straight stalks
which are rich golden yellow in color and solid and crisp, with the delicious flavor its appearance indicates. Pkt. $10 \mathrm{c}$; $0 \mathrm{z} .50 \mathrm{c}$; $1 /$ Ib. $\$ 1.50$; lb. $\$ 5.50$, postpaid.

259. Flavoring Celery. No for sowing. An excellent spicy flavoring for soups, salads, postpaid.

\section{CELERIAC}

Turnip-rooted Celery

One ounce will sow 800 feet of row

Culture. Seed should be started indoors and transplanted when large enough to stand 8 inches apart in the row. Use when the roots are about 2 inches across. Culture is much the same as celery except that it is not hilled up, the edible portion being the roots. Prefers well-manured, fairly moist soil. Frequent cultivation and frequent waterings during dry times produce the frnest roo

272. Large Smooth Prague.

A distinct variety with large, smooth, roots may be boiled or used in soups, stews, etc. Pkt. 10 c.; oz. 50 c.; $1 / 4 \mathrm{Jb} . \$ 1.50$; Ib. $\$ 5.50$, postpaid.

\section{CELTUCE}

241. Celtuce. (90 days.) A new vegetable rom China where the young leaves are eaten as lettuce and the hearts of the peeled stalks are eaten either raw or cooked. Here the young leaves are used in salads or boiled like other "greens" and the stem-hearts treated about as celery or carrots. The flavor is tantalizing in that it reminds one of so many different vege tables, depending on the preparation.

Sow thinly in rows as soon as ground can be worked and thin out to allow develop ment. Stalks will be ready for use in 90 days. Don't miss this new vegetable. Pkt.
$10 \mathrm{c}$; $1 / 4 \mathrm{oz} .20 \mathrm{c}$; $1 / 2 \mathrm{oz} .30 \mathrm{c}$; oz. $50 \mathrm{c}$, post-

\section{CHICORY}

$1 / 2$ ounce will plant 100 feet of row; 4 pounds, an acre

271. Witloof or French Endive. (110 days.) Seed should be sown in open ground not later than June and thinned out to stand 4 to 6 inches apart. The plants form large parsnip-shaped roots which are lifted in fall, trimmed of leaves and stored in soil in a cool place until wanted for forcing. Roots can be forced in a frame, greenhouse or warm cellar. This winter forcing produces attractive blanched heads which make pleasing salads. Pkt. 10c.; oz. $40 \mathrm{c}$.; $1 / 4$ Ib. $\$ 1.25 ;$ Ib. $\$ 4.50$, postpaid.

\section{COLLARDS}

One ounce will sow 200 feet of row

Collards is a large Kale popular in the South, and as a producer of winter and spring "greens" is unexcelled. Collards provide vitamins $A, C$ and $B_{1}$.

Culture. Sow thickly in rows any time up to September, in rich ground, transplanting when about 4 inches high, or sow where the plants are to remain and thin out to stand 2 feet apart.

36. Cabbage-Collards. (75 days.) A cross of Collards and cabbage, having a cabbage like flavor and growing 2 feet tall. Pkt. $5 \mathrm{c}$. oz, 10c.; 1/1 lb. 25c.; lb. 75c., postpaid.

211. Southern or Georgia. (75 days.) The old-time favorite which stands all kinds of adverse conditions without injury, providing good "greens" in soil too poor to grow cabbage. Pkt. 5c.; oz. 10c.; 1/4lb. $25 \mathrm{c}$; Ib. $75 \mathrm{c}$., postpaid.

\section{SUGAR OR SWEET CORN}

One pound plants 200 hills:

10 to 12 pounds, an acre.

We pay postage on Corn in pkts. and 1-, 2 and 5-1b. pkgs.

Larger quantities see page 2 for

Parcel Post rates.

Culture. Corn should never be planted For succession the middle of July. Corn thrives in rich,
well-manured ground. In hand-planting make a shallow hole with corner of the hoe, of soil, and press down with the hoe. Hills should be 3 feet apart. Thin out to 3 plants planted as

\section{Extra-Early Varieties (Not Sugar Corn)}

533. Adams' Extra Early.

ender and sweet when young. Pkt. $10 \mathrm{c}$

10 lbs. $\$ 1.10 ; 50$ Ibs. $\$ 4.50$, not

Ears are longer and a few d

Adams Extra Early. Pkt. 10c

$10 \mathrm{lbs} . \$ 1.00 ; 50 \mathrm{lbs}$. $\$ 4.00$, not postpaid.

511. Bolgiano's Early Ideal.

Large ears 7 to 10 inches long with mildly

avored kernels. Pkt. 10c.; Ib. 25c.; 2 Ibs.

40 c.; 5 lbs. 85c., postpaid.

10 lbs. $\$ 1.00 ; 50$ Ibs. $\$ 4.00$, not postpaid.

521. Truckers' Favorite. ( 80 days.) A

favorite in the South. Pkt. 10c.; Ib. 25c.; 2 Ibs. $40 \mathrm{c}$.; 5 Ibs. $85 \mathrm{c}$., postpaid.

10 lbs. 95 c.; 50 Ibs. $\$ 3.75$, not postpaid.

\section{Early Varieties}

524. Bolgiano's New Cream and Honey. 80 days.) It grows 4 feet tall and produces two or three, 5 to 8 -inch ears of deliciously sweet kernels of rich flavor

Pkt. 10c.; Ib. 35c.; 2 lbs. 55c.; 5 lbs. \$1.15,

postpard.

10 lbs. $\$ 1.70 ; 50$ Ibs. $\$ 7.50$, not postpaid.

514. Extra-Early Evergreen. ( 80 days.

Stowell's Evergreen. Pkt. 10c, ;b. 35c.

2 lbs. 55c.; 5 Ibs. \$1.10, postpaid.

10 lbs. $\$ 1.60 ; 50$ lbs. $\$ 7.00$, not postpaid.

519. Golden Bantam. ( 80 days.) Delicious yellow Corn which is yet one of the

lb. 35 c. 2 Ibs. 55 c. 5 lbs. $\$ 1.10$, postpaid 10 lbs. $\$ 1.60 ; 50$ lbs. $\$ 7.00$, not postpaid.

532. Howling Mob. ( 85 days.) An early white variety with 7 to 9 -inch ears having

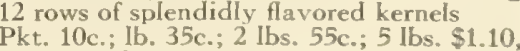
postpaid. 10 lbs. $\$ 1.60 ; 50$ Ibs. $\$ 7.00$, not postpaid.

\section{Late Varieties}

523. Black Mexican. (87 days.) The seed is black but kernels are white at

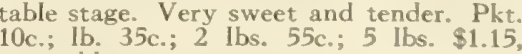
postpaid.

10 lbs. $\$ 1.70 ; 50$ Ibs. $\$ 7.50$, not postpaid.

515. Country Gentleman or Shoe-Peg. (95 days.) The deep shoe-peg kernels are set irregularly instead of in rows and the quality is first class. Pkt. 10c.;

Ibs. $55 c_{.}: 5$ lbs. $\$ 1.10$, postpaid.

10 lbs. $\$ 1.60 ; 50$ lbs. $\$ 7.00$, not postpa
5030. Golden Country Gentleman.

days.) A very sweet variety of the Cou

2 try Gentleman type. Pkt. $10 \mathrm{c}$

10 Ibs. $\$ 1.70 ; 50$ Ibs. 
322. Extra-Large Leeks. Pkt. 10c.

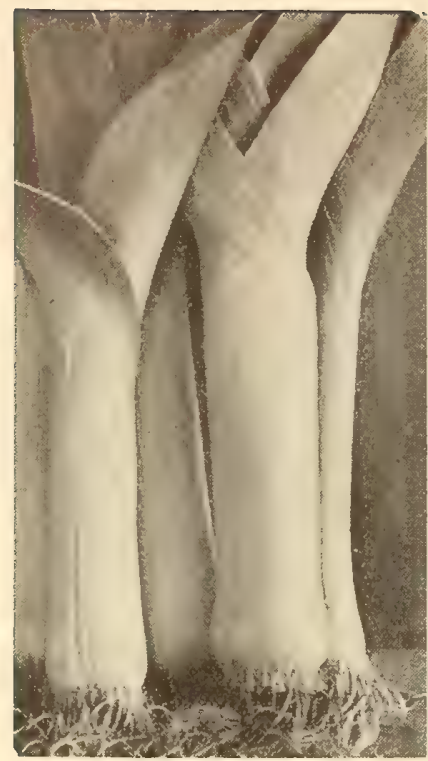

\section{FOR VARIETY}

The five top vegetables on this page are seldom grown in the average garden. Add variety to your table with these. Some will please you, others may not. It costs little to find out.

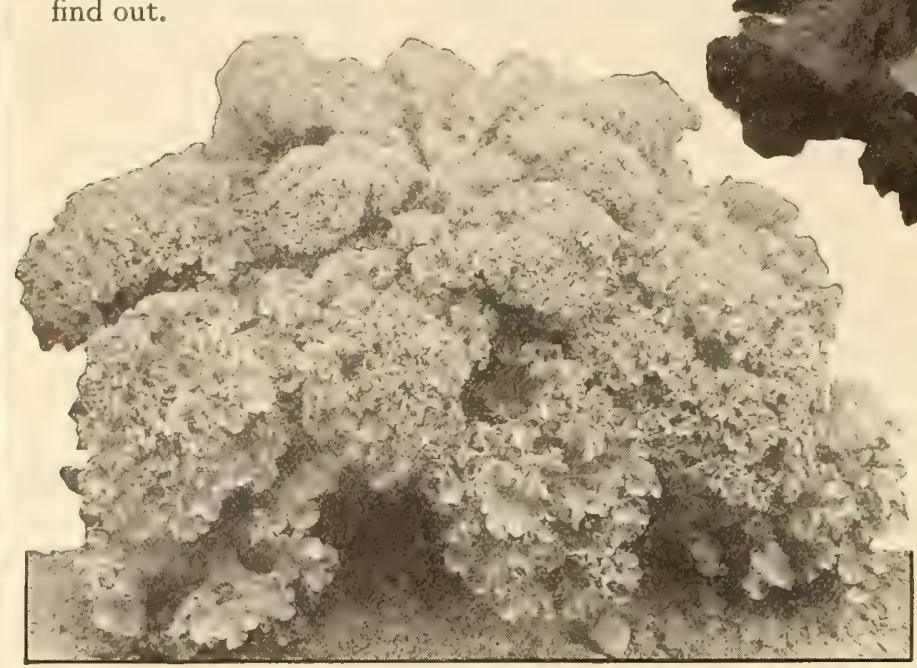

133. Blue Curled Scotch Kale. Pkt. 10c.

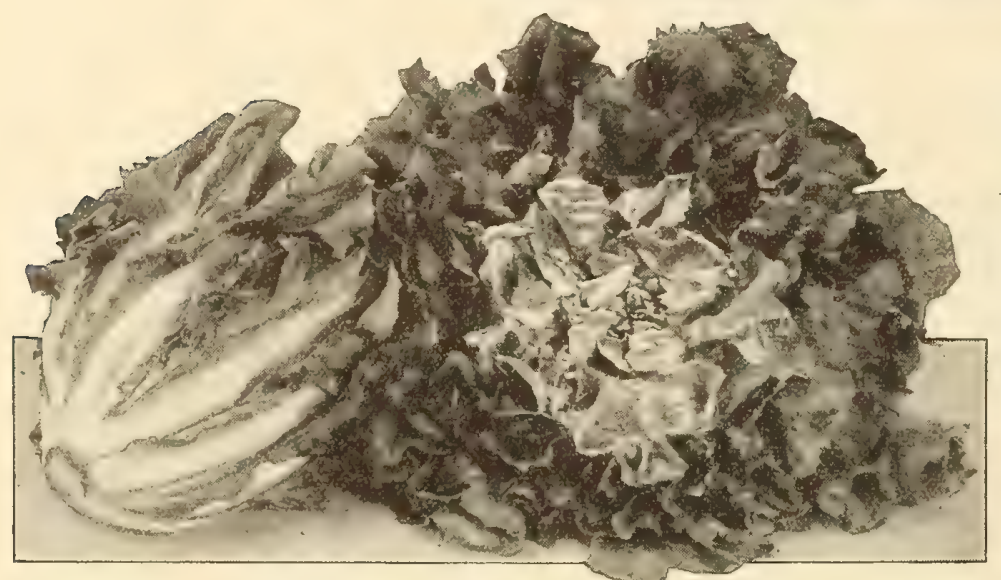

198. Batavian Full-Heart Endive. Pkt. 10c.

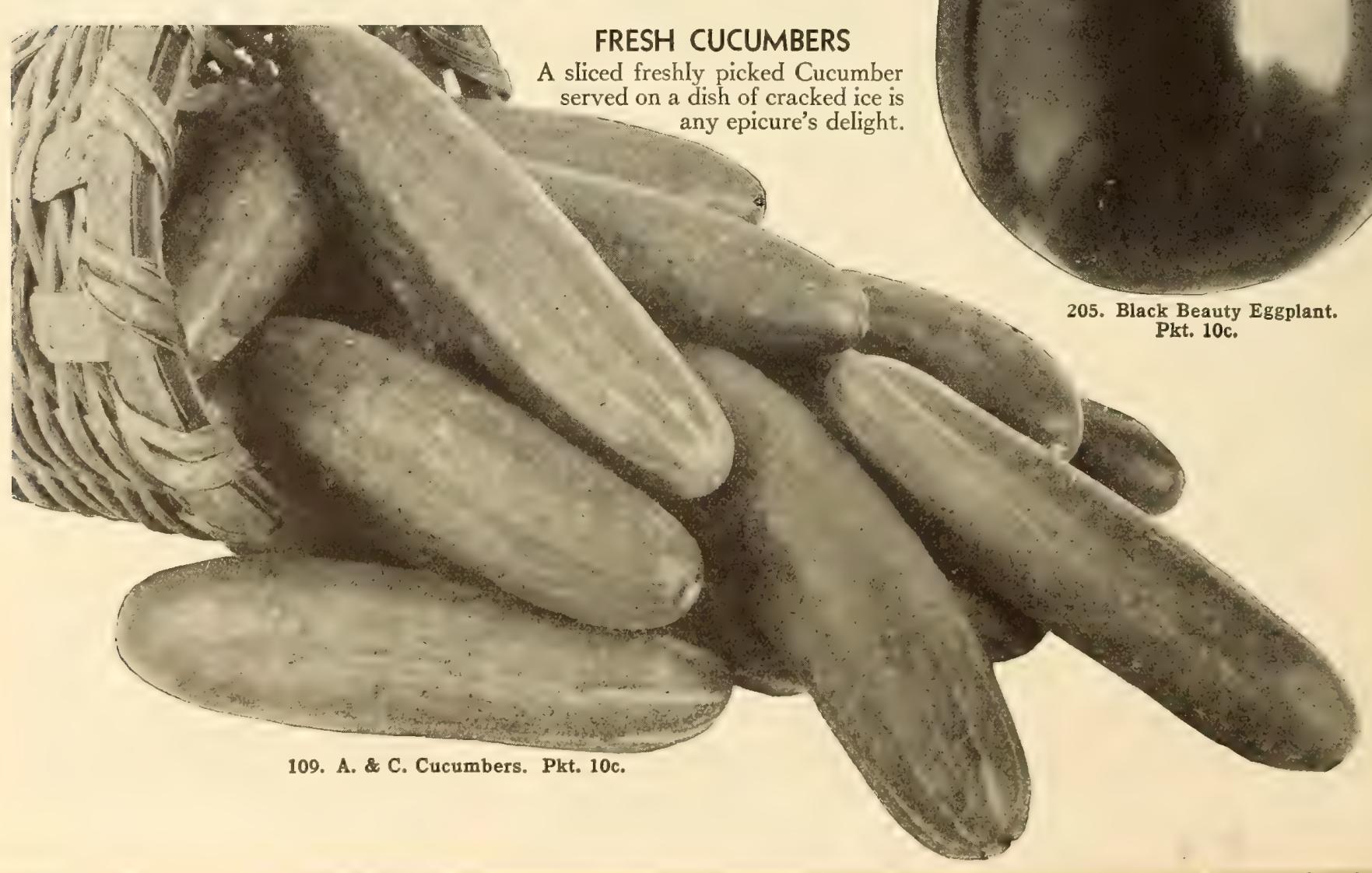

\begin{abstract}
HOME-MADE this catalogue for ideas on better, easier gardening.
\end{abstract}

PICKLES

Most everyone likes Pickles of various kinds and can find many things in today's garden to pickle as well as $\mathrm{Cu}-$ cumbers.

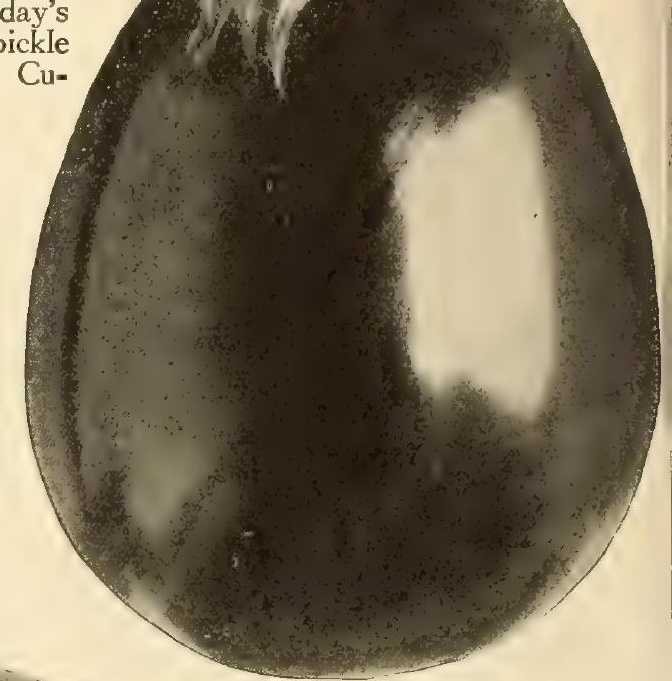
quickly pay for itself in better gardening and effort conserved. Look over the Planet Jr. line on page 58 of any housewife 
SUGAR or SWEET CORN, continued

536. Golden Evergreen. ( 85 days.) A splendid variety to follow Golden Bantam with larger and better filled ears of golden kernels. Pkt. 10c.; Ib. 35c.; 2 Ibs. 55 c.; 5 lbs. $\$ 1.10$, postpaid.

10 lbs. $\$ 1.60 ; 50$ lbs. $\$ 7.00$, not postpaid.

535. Snow-White Evergreen. (90 days.) A purer white Stowell's Evergreen. Pkt. 10c.; lb. 35c.; 2 lbs. $55 \mathrm{c}$; 5 Ibs. $\$ 1.10$, postpaid

10 Ibs. $\$ 1.60 ; 50$ lbs. $\$ 7.00$, not postpaid.

518. Stowell's Evergreen. (95 days.) Our selected stock has been of the true deep strain and evergreen character. The ears are large and the white kernels are sweet and tender. Pkt. 10c.; lb. 35c.; 2 lbs. 55c.; 5 Ibs. $\$ 1.10$ postpaid.

$10 \mathrm{Ibs} . \$ 1.60 ; 50 \mathrm{lbs} . \$ 7.00$, not postpaid.

\section{Hybrid Sugar Corns}

520. Golden Cross Bantam. (85 days.) "Best-in-Garden" variety. Maturing 4 to 5 days later than Golden Bantam this hybrid is resistant to wilt and is a heavy producer. Ears average 12 rows of golden yellow kernels. Pkt. 10c.; lb. 40c.; 2 Ibs. 70 c.; 5 lbs. $\$ 1.75$, postpaid.

10 lbs. $\$ 2.80 ; 50$ lbs. $\$ 13.00$, not postpaid.

534. Ioana. ( 85 days.) Bronze Medal, 1940 All-America Selections. It is resistant to both wilt and drought and bears $71 / 2$ - to 8-inch light yellow ears. Pkt. 10c.; Ib. $40 \mathrm{c}$; 2 Ibs. $70 \mathrm{c}$.; 5 lbs. $\$ 1.90$, postpaid.

10 lbs. $\$ 3.20 ; 50$ lbs. $\$ 15.00$, not postpaid.

507. Hybrid Stowell's Evergreen. (98 days.) Bronze Medal, 1934 All-America Selections. Sturdy stalks bear slightly tapered ears with 16 to 18 rows of deep white kernels. Pkt. 10c.; Ib. 45c.; 2 Ibs. 80 c.; 5 Ibs. $\$ 2.00$, postpaid.

10 lbs. $\$ 3.40 ; 50$ lbs. $\$ 16.00$, not postpaid.

510. Marcross. ( 72 days.) 6 to $71 / 2$-inch ears averaging 12 rows of light yellow, very sweet kernels. Pkt. 10c.; Ib. 40 c.; 2 lbs. 70 c.; 5 Ibs. $\$ 1.80$, postpaid.

10 Ibs. $\$ 3.00 ; 50$ Ibs. $\$ 14.00$, not postpaid.

\section{POP-CORN}

537. White Rice. (110 days.) Short ears with long, pointed translucent kernels which pop snow-white.

Pkt. 10c.; Ib. 25c., postpaid.

\section{CORN SALAD}

Three ounces of seed will sow 100 feet of row

A mildly flavored vegetable planted for late fall, winter and spring use.

The plants are quite hardy and furnish tender leaves useful for salads especially when mixed with other herbs or can be cooked as spinach for "greens."

112. Broad-leaved. (60 days.) The best variety. Crop failed.

\section{CRESS}

One ounce will sow 100 feet of row

The Cresses furnish warm, pungent flavor to salads and are useful for garnishing.

Culture. Water-Cress may be grown in moist ground but does best in shallow clear running water. Upland Cress should be sown thickly in shallow drills every 2 to 3 weeks in ordinary rich soil and should be cut often.

137. American Upland. (60 days.) A frne salad plant with about the same flavor as Water-Cress, Desirable because it grows in ordinary soil and is ready to pick in two months, or less. Pkt. 10c.; oz. 15c.; 1/4lb. 40c.; lb. \$1.25, postpaid.

270. Water-Cress. This delicious salad plant is a true perennial and everyone with a shallow stream should have a bed of Cress. Pkt. 25c.; oz. \$1.00, postpaid.

\section{CUCUMBER}

One ounce will plant 50 hills; two pounds, an acre

Prices include postage on pkts., ozs., $1 / 4 \mathrm{lbs}$, and lbs.

Culture. Cucumbers prefer rich, Ioamy, fairly moist soil and should not be planted until ground is warm. Plant in hills, dropping 6 to 8 seeds in each hill and covering soil; thin to 3 or 4 strongest hill. Continue planting at intervals for succession. Cucumbers for pickles may be planted during June and early July. For an extra-early crop start seed in small pots in hotbeds.

109. A. and C. (68 days.) A leading market variety which makes a good appearance after shipping. Fruits are uniform, very dark green and taper slightly at ends. They average $21 / 4$ inches through and up to 10 inches long. Vines are vigorous and disease-resistant. Pkt. 10c.

73. Arlington White Spine (60 days.) A standard early variety 8 oz. 20 c.; $1 / 1 / \mathrm{lb}$. 60 c.; Ib. $\$ 1.75$, postpaid.

131. Bolgiano's Early Fortune. (65 da Growers delight in the uniformity of the
fruits of this variety. They average $9 x$ $21 / 2$ inches, are dark in color, and quality is excellent. Being free from bitterness and exceedingly crisp it is ideal for slicing. Market people praise its unfading color. postpaid.

169. Bolgiano's Prosperity. (65 days.) An extra-early Cucumber with uniformly large, symmetrically formed fruit white Vines are vigorous, mildew-proof and rarely produce a cull. Try this for an early crop. Pkt. 10 c.; oz. 20c.; $1 / 4 \mathrm{Ib}$. 65 c. Ib. $\$ 2.00$, postpaid.

251. Gherkin or Small Burr. (60 days.) Small spiny fruits used when small for
pickling. Pkt. 10c.; oz. 20c.; $1 / 4 \mathrm{Ib} .65 \mathrm{c}$; Ib. $\$ 2.00$, postpaid.

326. Imperator or Clark's Special. (65 days.) Very productive variety which holds its deep green color when shipped, appearing fresh when it reaches market. Quality is definitely superior. Pkt. 10c. oz. 20 c.; $1 / 4$ Ib. 65 c.; Ib. $\$ 2.00$, postpaid.

228. Jersey Pickling. ( 60 days.) A standard pickling variety with uniform slender fruits of medium green color. Pkt. $10 \mathrm{c}$. oz. 20 c.; $1 / 4 \mathrm{lb} .65 \mathrm{c}$.; Ib. $\$ 2.00$, postpaid.

301. Longfellow. (70 days.) Long slender Cucumber which grows 12 to 14 inches but best picked when about 10 inches Iong and 2 inches in diameter. Fruits are smooth, dark green and look like a hothouse product. Pkt. 10c.; oz. 25c.; $1 / 4 \mathrm{Ib}$. 70 c.; $1 \mathrm{~b} . \$ 2.25$, postpaid.

156. Long Green. ( 67 days.) A large, deep green, heavily warted variety with solid, crisp flesh. It often grows to 12 inches and is an ideal large pickle Cucumber. Pkt. 10c.; oz. 20 c.; $1 / 4$ lb. 65 c.; Ib. $\$ 2.00$, postpaid.

93. Stays Green or Black Diamond. $(60$ days.) Symmetrical fruits of dark green with nearly square ends. They are smooth, 7 to 8 inches long, and the flesh is white and crisp. Pkt. 10c.; oz. 20c.; 1/4 Ib. $60 \mathrm{c}$. lb. $\$ 1.75$, postpaid.

42. Straight-8. ( 66 days.) Gold Medal, 1935 All-America Selections. This splendid Cucumber averages 8 inches in length by $11 / 2$ inches in diameter. Fruits are uniform in shape and of a rich, deep green color which is free from striping. Pkt. $10 \mathrm{c}$.

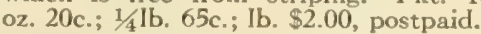

313. Snow's Pickling. ( 56 days.) An early, small variety which pleases the bottlers of small pickles. Fruits are dark green, cylindrical and square ended. Pkt. $10 \mathrm{c}$. oz. 20 c.; $1 / 4$ Ib. 65 c.; Ib. $\$ 2.00$, postpaid.

\section{EGGPLANT}

One ounce will produce at least 1000 plants; $1 / 41$ b. will sow an acre

Culture. Eggplant seed germinates slowly and should be started in a hotbed and
planted out when plants are 2 inches high, provided both soil and air are warm; they 205. Black (110 days.) "Best-inEarliest and best of inch large-fruited varieties. The 24 - to 30 ained for a long time. Pkt. 10c.

339. Florida High-Bush. (120 days.) A

thornless, hardy variety which is disease-
resistant. The oblong purple fruits are
good keepers and ship well. pkt. 10c.;

oz. 50c.; 1/4lb. \$1.15; lb. $\$ 4.00$, postpaid.

166. Fort Myers Market. (120 days.) Tall

plant which holds its fruit clear of the attractive fruit of glossy, purplish black.

Pkt. 10 c.; oz. 50 c.; 1/4lb. $\$ 1.25$; Ib. $\$ 4.50$,
postpaid.

\section{ENDIVE}

One ounce will sow 150 feet of row; 3 pounds, an acre

Endive furnishes vitamins $A$ and $C$ and $a$ fair amount of iron.

Culture: As Endive is usually used for fall and winter salads the seed should be thinned out to stand 1 foot apart in the row. When nearly grown tie the outer leaves together to blanch the hearts. For an early crop the seed should be sown about April 15.

198. Batavian Full-Heart. ( 90 days.

An earlier and improved strain with

larger leaves and broader, thicker heads requiring very little blanching.

Pkt. 10c.; oz. 15c.; 1/4lb. 40c.; Ib. \$1.25,

43. Green Curled. (95 days.) A selfblanching variety. Curly, dark green leaves which are finely cut give the plant a $1 / \mathrm{Ib} .35 \mathrm{c}$; Ib. $\$ 1.00$, postpaid.

285. White Curled. (100 days.) Plants grow 1 foot in diameter with finely curled leaves. The broad ribs are slightly tinged with rose and the heart is creamy white. Pkt. 10c.; oz. 15c.; 1/4lb. 35c.; Ib. \$1.00, postpaid.

\section{KALE or BORECOLE}

One ounce will sow 200 feet of row; 4 pounds, an acre

Kale is a vitamin and mineral special, providing vitamins $A, C$ and $B_{1}$, and riboflavin, calcium and iron, the first two vitamins in top quantities.

Culrure. This hardy vegetable furnishes splendid "greens" for winter and spring use, the quality being improved by some frost. Sow seed $1 / 2$ inch deep in rows from May to September. If large plants are wanted, thin to stand $11 / 2$ to 2 feet apart in row.

133. Dwarf Blue Curled Scotch or Curled Beauty. (55 days.) Beautiful dwarf plants which lie flat on the ground forming a double-deck: withstands frast and seldom winter-kills where temperatures do not go below zero. The heavily curled leaves are a distinct blue-green color, attractive and of high quality. Pkt. $10 \mathrm{c}$

121. Dwarf Green Curled Scotch Norfolk. (55 days.) Similar to Dwarf Blue except that this is a medium green color and like Dwarf Blue a heavy prooz. $25 \mathrm{c}$; $1 / 4 \mathrm{lb} .75 \mathrm{c}$; lb. $\$ 2.50$, postpaid. 


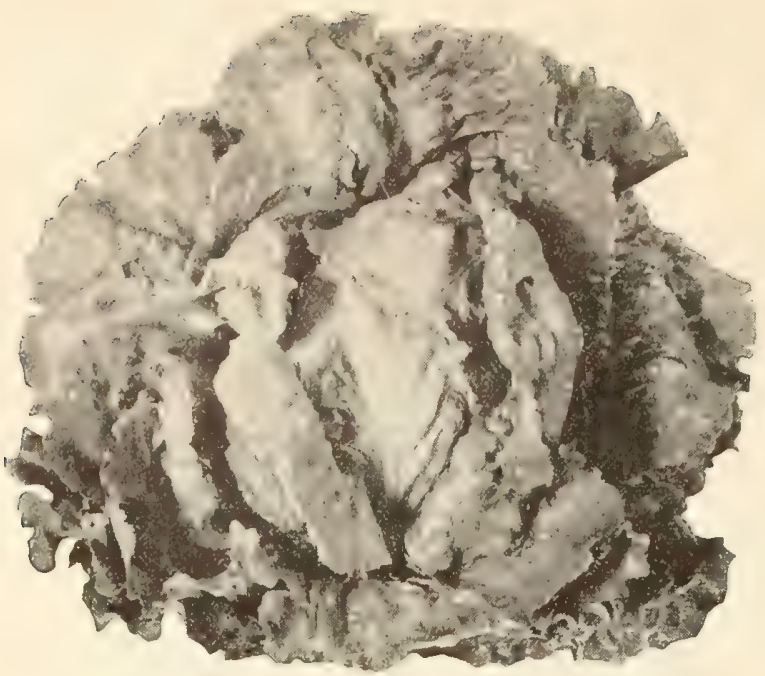

92. Bolgiano's Masterpiece Lettuce. Pkt. 10c.

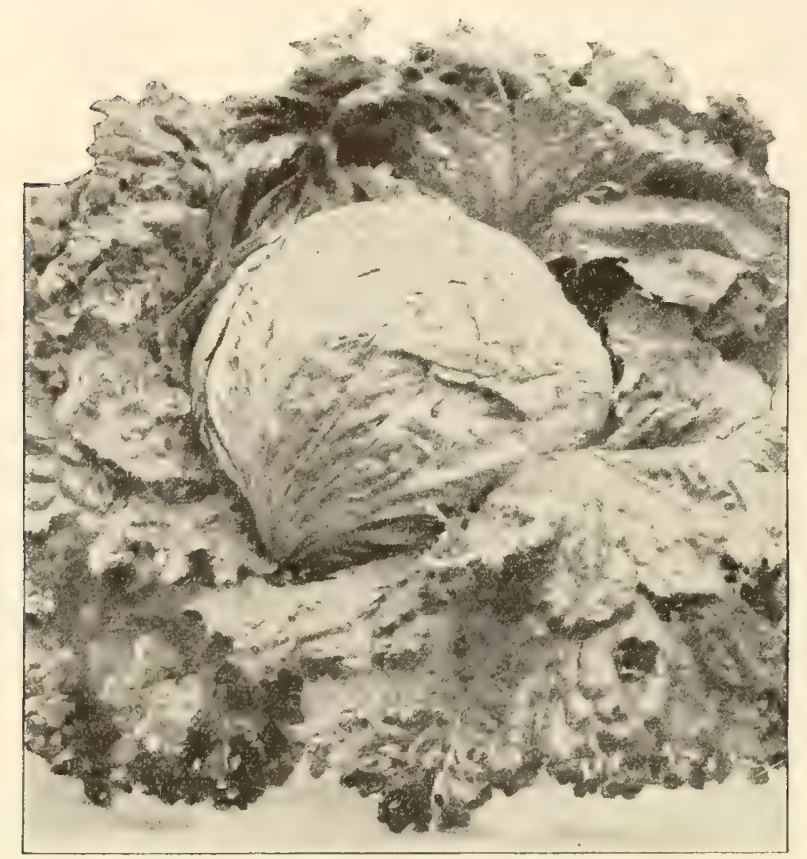

324. Imperial 847 Lettuce. Pkt. 10c.

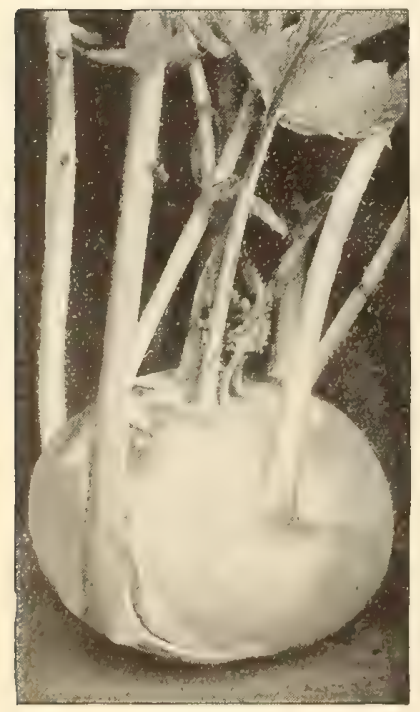

310. Early White Vienna

Kohlrabi. Pkt. 10c.

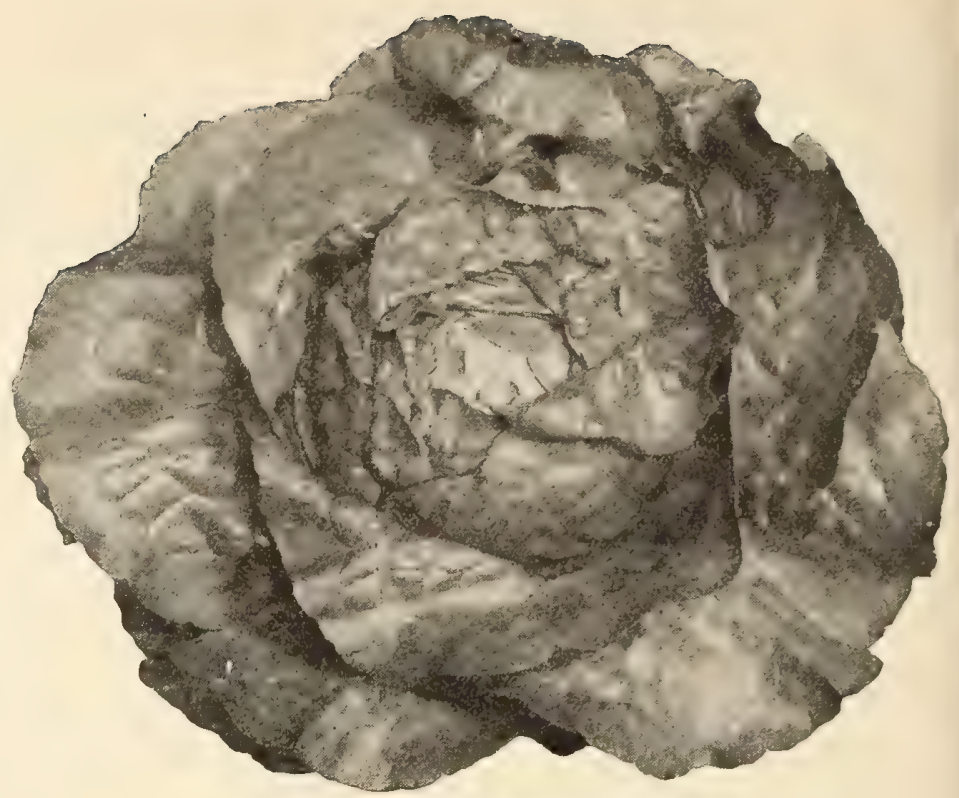

58. Big Boston Lettuce. Pkt. 5c.

\section{BETTER LETTUCE}

With well-fertilized soil, kept cultivated and watered during dry times, the home gardener can grow better, tastier Lettuce than any bought in market after a 3000-mile journey.

Whether you want flavorsome green leaves of the loose varieties or the hard white blanched heads of the Iceberg type, your garden can produce them.

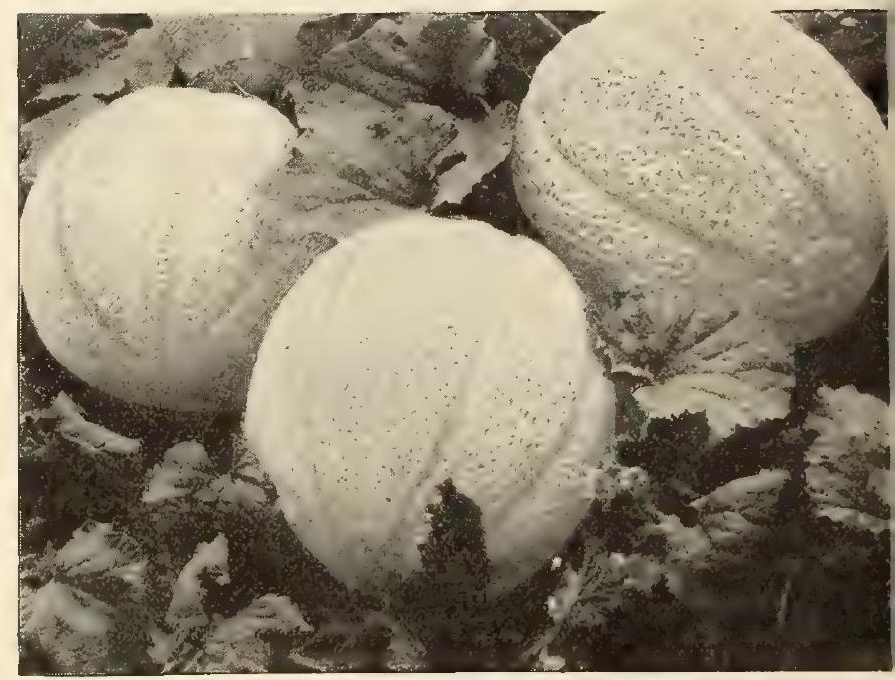

104. Hale's Best Cantaloupe. Pkt. 10c.

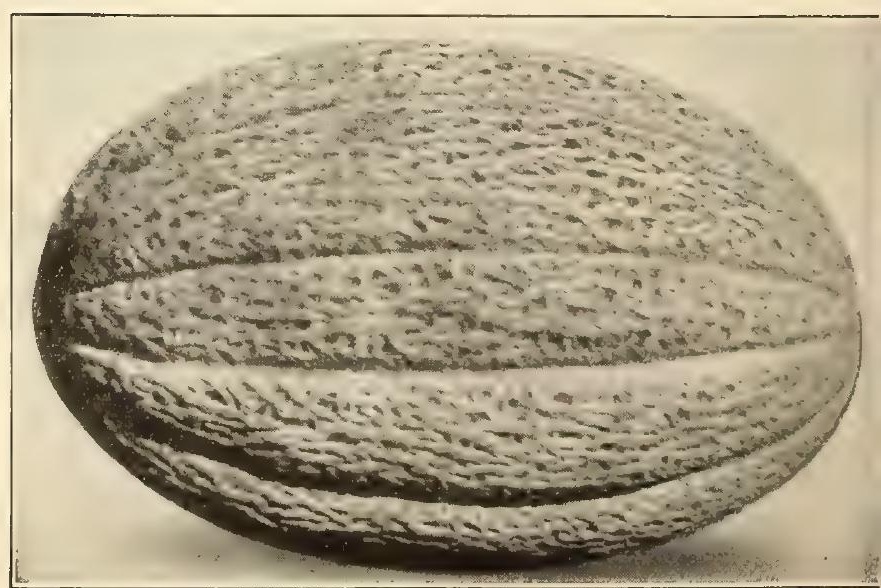

102. Long John Cantaloupe. Pkt. 10c. 
KALE or BORECOLE, continued

76. Imperial Curly Long Standing. 155 days.) "Best-in-Garden" variety. A
beautifully curled and crimped sort of beautifully curled and crimped sort of
strong vigorous habit; perfectly hardy; dark green in color, and very attractive in appearance. It will stand longer without shooting to seed than any other variety. Pkt. 10c.; oz. 20c.; $1 / 4 \mathrm{lb}$. 50c.; lb. $\$ 1.50$, postpaid.

66. Siberian Curled. (65 days.) Large, very spreading, hardy and vigorous plant. Big plume-like leaves, thick in texture, curled at edges; deep green in color. Pkt. 10c.; oz. 20c; ; 1 Ib. 50c.; Ib. $\$ 1.50$, postpaid.

69. Tall Green Curled Scotch. (60 days.) A dependably hardy Kale growing 2 feet high with abundant dark green, very $75 \mathrm{c}$. ; Ib. $\$ 2.50$, postpaid.

\section{KOHLRABI}

One ounce sows 200 feet of drill; 4 pounds, an acre

Culture. Sow as early in spring as possible, in rows, thinning out to stand 6 inches apart in the row. For a succession sow every two weeks until hot weather. Sow in late July for a fall crop. The bulbs should be used when young and not over $21 / 2$ inches through; large bulbs will be woody. 310. Early White Vienna. (55 days.) Picked when young and tender and properly prepared for the table, this vegetable is a splendid food with a flavor resembling both cauliflower and turnip. Easy to grow and requiring no more care than cabbage, it is one of those "different" things everyone should try. Pkt. 10c.; oz. 40c.; $1 / 4 \mathrm{lb}$. $\$ 1.25 ;$ Ib. $\$ 4.00$, postpaid.

\section{LEEK}

One ounce will sow 100 to 200 feet of row; 4 pounds, an acre

Culture. Leeks prefer light soil and should be sown in early April, in rows, covering the seed $1 / 2$ inch deep. After the plants are thinned, or transplanted, to stand 6 inches apart in the row, more soil should be pulled over the roots, blanching them. If earthed up like celery the Leeks will be very white and tender. A crop may be sown in August or September for early spring transplanting.

322. Extra Large. (120 days.) Hardy, productive and of the best quality.

Plkt. 10c.; oz. $80 \mathrm{c}$; $1 / 4 \mathrm{lb}$. $\$ 2.50$, postpaid.

201. Evergreen. (120 days.) Stems thick, dark green in color.

Pkt. 10c.; oz. 80c.; 1/4 lb. $\$ 2.50$, postpaid.

\section{LETTUCE}

One ounce will sow 300 feet of row; 3 pounds, an acre

Lettuce is an excellent source of vitamin A and furnishes a goodly quantity of vitamin C.

Culture. Sow seed in rows as soon as the ground can be worked. Cover the seed 1/2 inch deep and press soil down firmly, or it may be sown in a hotbed in February or March, transplanting to a sheltered position for an early crop. Thin plants to 8 inches apart for good head Lettuce or have plants close together for loose-leaf Lettuce. Lettuce does best during cool, moist weather.

\section{Heading Varieties}

58. Big Boston. Special Stock. (75 days.) A real all-season Lettuce of the Butterhead type, succeeding in frames for spring and outdoors for summer and fall. Handsome large heads with outer leaves tinged with bronze at edges and blanched hearts of rich buttery yellow; crisp, tender and sweet. Pkt. 5c.; oz. 20c.; 1/41b. 50c.; lb. $\$ 1.50$, postpaid.
92. Bolgiano's Masterpiece.

"Best-in-Garden" variety. A great Lettuce for late spring, summer, and early fall, as no matter how hot the weather or how long it remains in the garden it will keep crisp. tender and sweet and it will not go to seed quickly. It is a sure header and stands shipping better than any Lettuce we know. postpaid.

60. Bolgiano's Black-Seeded Summer. (70 days.) A perfect heading outdoor Lettuce especially desirable during our and pleasant flavor under those conditions. It has also forced well under glass and is a splendid member of the Butterhead family. Pkt. 10c.; oz. 20c.; 1/4l Ib. 50c. Ib. $\$ 1.50$, postpaid.

98. Early May King. (60 days.) A quickgrowing Butterhead sort popular for
earliest outdoor planting and greenhouse forcing. Outdoor plantings quickly make 6 to 7 -inch heads with broad outer leaves folding closely around the solid center. In cool weather the outer leaves have brownish tinge adding to the appearance. The heart blanches to rich golden yellow and has an especially fine rich buttery flavor. We recommend spring plantings and again during August and September for fall crops. Pkt. 10c; oz. 20c.; 1/4Ib. 60c. Ib. $\$ 1.75$, postpaid.

146. Golden Queen. ( 55 days.) An extraearly heading Lettuce. Medium size with solid heads having crisp and tender golden yellow hearts. Pkt. 10c.; oz. 25c.; $1 / 4 \mathrm{lb}$. 75 c.; Ib. $\$ 2.50$, postpaid.

344. Hanson. (80 days.) A sure-heading ald favorite Crisp-head. The yellowish green heads are tender and sweet and without any bitter taste. Pkt. 10c; oz. 20c.; 1 I Ib. 50c.; Ib. $\$ 1.50$, postpaid. 55. Iceberg. (82 days.) A popular hard-
headed Lettuce adapted for either spring headed Lettuce adapted for erther spring
or summer use. The wavy, light green, outer leaves are tinged reddish brown at edges and the hearts are unusually white, crisp and sweet. Pkt. 10c.; oz. 20c.; $1 / 4 \mathrm{Ib}$ $65 \mathrm{c}$. I Ib. $\$ 2.00$, postpaid.

324. Imperial 847. (83 days.) A New Yorktype Lettuce especially adapted for eastern and southern use. Heads are medium large and of great solidity, standing hot weather well. It is resistant to brown blight.

Pkt. 10c.; oz. 25c。; 1/4lb. 75c.; Ib. $\$ 2.50$, postpaid.

318. Improved Salamander.

A head having a buttery interior of excellent quality. Pkt. 10c.; oz. 20c。; 1/41 Ib. 50c.; Ib. $\$ 1.50$, postpaid

71. New York 12. (77 days.) Immense heads with the leaves closely folded. Inner portion blanches readily and is always crisp and tender. Pkt. 10c.; oz. 25c.; $1 / 4 \mathrm{Ib}, 70 \mathrm{c}$; Ib. $\$ 2.25$, postpaid.

120. Unrivalled or White Boston. (76 days.) An outstanding Lettuce with a light green head and buttery yellow heart Resembles Big Boston in appearance and size of head. Pkt. 10c.; oz. 20c.; 1/4Ib. 60c. Ib. $\$ 1.75$, postpaid

342. Wayahead. (63 days.) An early Butterhead heading well under varying conditions. Heads are small and attractive with golden yellow interiors of good flavor. Pkt. 10c.; oz, 20c.; 1/4 Ib. 50c.; Ib. $\$ 1.50$, postpaid

Loosehead or Cutting Varieties 297. Black-seeded Simpson. (45 days.) The frilled and crumpled leaves of light yellowish green are crisp and tender. It is an attractive early cutting variety.

Pkt. 10c.; oz. 20c.; 1/4lb. 50c.; lb, \$1.50,

199. Early Curled Simpson or Silesia. (45 days.) Compact plants with broad, frilled, lustrous bright green leaves. Popular with home gardeners. Pkt. 10c; oz. 20c.; $1 / 4$ Ib. 50c; Ib. $\$ 1.50$, postpaid.
350. Grand Rapids.

early variety makin

broad, wavy, hea
leaves. Very tend

oz. $20 \mathrm{c}$.

Cos or Romaine Lettuce

240. Dark Green.

12-inch

very dark green and sligitl. Leaves

Pkt. 10c.;

184. Paris White or Trianon.

Heads are 8 to 10 inches tall,

leaves medium light green, the interior greenish white. A splendid summer sala oz. $20 \mathrm{c} ; 1 / 4 \mathrm{lb} .50 \mathrm{c}, \mathrm{ib} . \$ 1.50$, postpaid

\section{MUSKMELON OR CANTALOUPE}

One ounce will plant 50 hills;

2 to 3 pounds, an acre

Culture. Melons thrive in rich light soil. Plant in hills 4 to 6 feet each way in early May, placing a forkful of old manure under each hill and 10 to 12 seeds in each hill, plants are well established. Pinching off ends of vines when they are a foot long will increase production. For an early crop start seeds in small boxes in a hotbed.

\section{Green-fleshed Varieties}

347. Bolgiano's Baltimore Nutmeg.

\section{days.) A large, green-fleshed Canta}

as sweet as sugar. Pkt. 10

123. Bottomley or Anne Arundel. days.) An oblong, ribbed, heavily netted melon with solid thick green flesh. The flavor is delicious. Vines are quite diseaseresistant. Pkt. $10 \mathrm{c}$

210. Honey Dew. (110 days.) Round, greenish white, smooth melons with thick green flesh having a distinct flavor of its own. Not good until dead ripe. Pkt, 10c. oz. 20c.; $1 / 4$ Ib. 50c.; Ib. $\$ 1.50$, postpaid.

102. Long John.

Garden" variety. This great Cantaloupe comes from Anne Arundel County, Marydeeply netted and ribbed melons average 8 to 10 inches long so that it does not take many to fill a basket. The thick green flesh is really delicious. Try this one for

$1 / 4 \mathrm{lb} .70 \mathrm{c}$.; Ib. $\$ 2.25$, postpaid.

193. Knight or New Maryland.

The heavily netted, ribbed fruits of golde yellow weigh about 2 pounds each. Its Juicy green flesh shades to pink at center. oz. 20c.; 1/4 Ib. 50c.; Ib. $\$ 1.50$, postpaid

39. Rocky Ford or Netted Gem.

Known everywhere for its finely flavored II Ib. 50 c.; Ib. $\$ 1.50$, postpaid.

226. Rocky Ford, Jr.

and more productive than its resists both rust and blight. The healthy vines produce heavy crops of fine shipping melons. Closely netted skin covers thick green, very sweet flesh. Pkt.
$1 / 1 \mathrm{lb} .70 \mathrm{c}$.; $1 \mathrm{~b} . \$ 2.25$, postpaid.

41. Sweet Air. (82 days.) "Best-in-Garden" early variety. This wonderful melon is
medium in size. Thick green flesh with small cavities, delicious perfectly tender; it fairly melts in mouth. Vigorous grower; vines keep green and produce big crops of beautiful ne melons. Pkt. $10 \mathrm{c}$. 


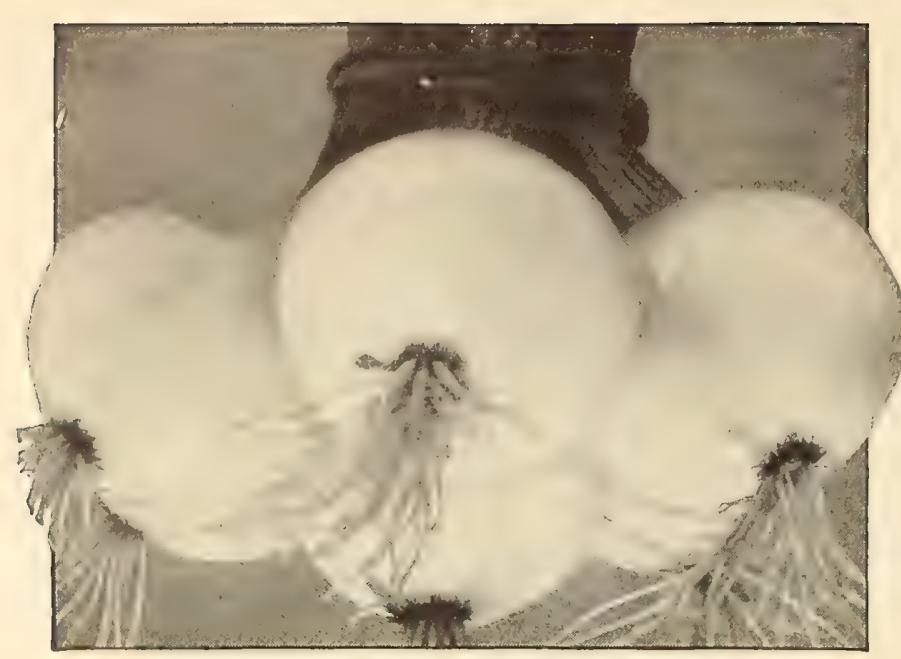

85. White Silverskin Onions. Pkt. 10c.

\section{ONIONS}

By planting seed the gardener can have variety, from the tiny pickling Onions up to mammoth, mild, sweet Spanish Onions. Onions pay large dividends on the small space occupied.

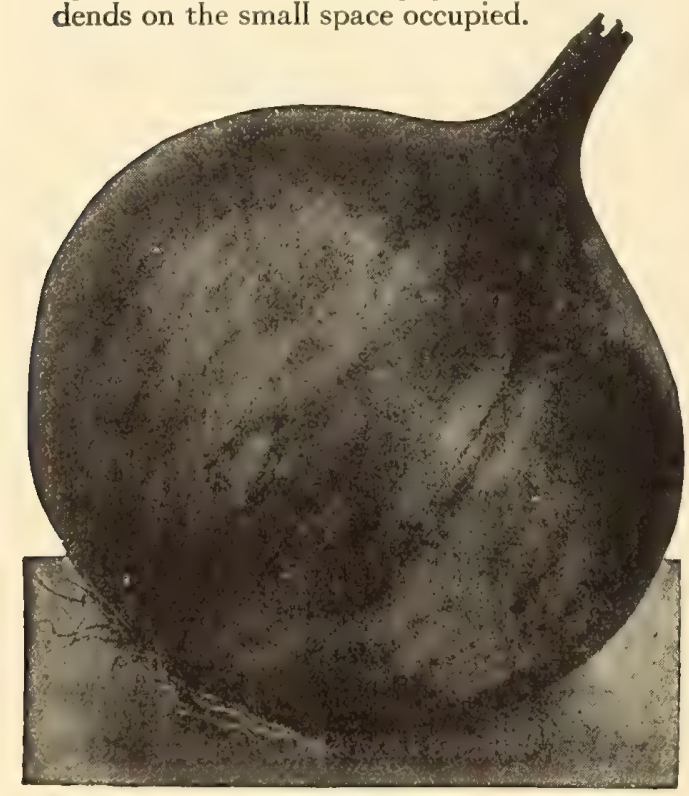

296. Yellow Globe Danvers Onion. Pkt. 10c.

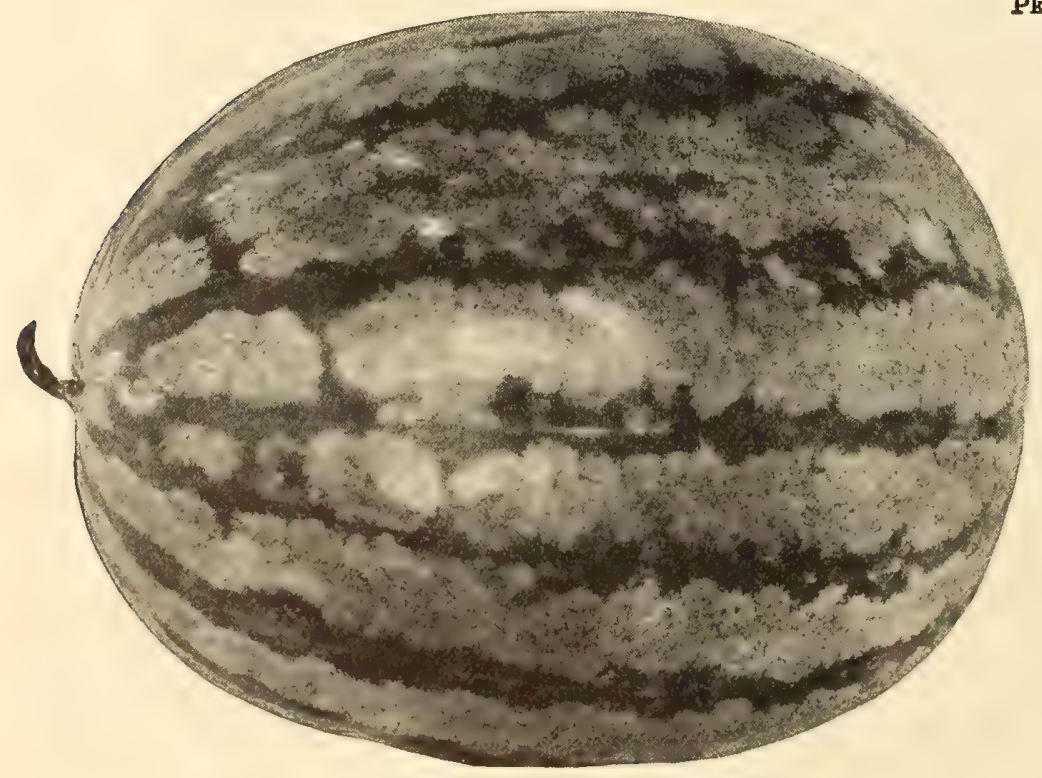

149. Dirie Queen Watermelon. Pkt. 10c.

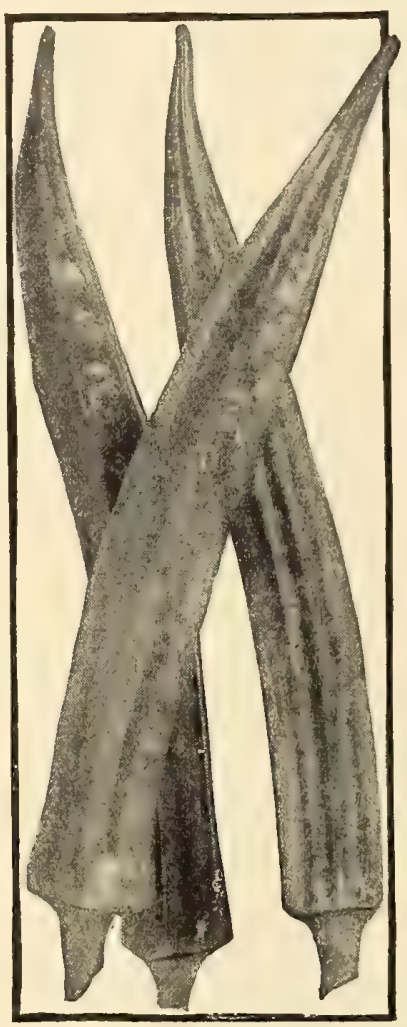

224. Prizetaker Onions. Pkt. 10c.

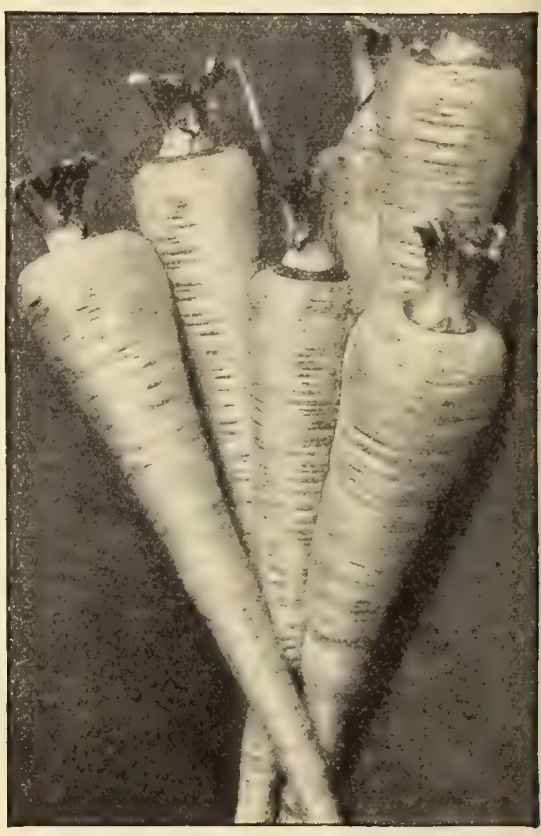

83. Hollow Crown Sugar Parsnips. Pkt. 5c.

Plrt. 5c. 


\section{MUSKMELON, continued \\ Salmon-fleshed Varieties}

230. Bolgiano's Unsurpassed. (90 days.) Good to look at, good to eat-this highly flavored melon is excellent for shipping or local marketing. The vigorous-growing fruit is deep orange around the cavity, shading to green at the rind; heavily netted; $41 / 2$ to $51 / 2$ inches in diameter; oz. 20c : $3 / \mathrm{Ib}, 65 \mathrm{c}$ - Ib, $\$ 2.00$, postpaid

104. Hale's Best, No. 36. (82 days.) Attractive melons with heavy netting and inconspicuous ribs. Exceptionally thick, deep salmon flesh of fine sweet flavor. A very small seed-cavity. Pkt. 10 .

215. Hearts of Gold. ( 90 days.) Nearly round fruits averaging 3 pounds each, distinctly ribbed and covered with fine gray netting. The deep salmon flesh is very thick, sweet, juicy and fragrant. Pkt. 10c.; 0z. 25 c.; $1 / 4 \mathrm{Ib} .75 \mathrm{c}$; Ib. $\$ 2.50$, postpaid.

63. Pollock 10-25. (90 days.) A salmon Rocky Ford with heavily netted skin. The salmon-tinted flesh is deep, leaving little seed-cavity, Delicious sweet flavor. Pkt. $10 \mathrm{c}$; oz. 20c.; $1 / 1 \mathrm{lb}$. $60 \mathrm{c}$.; Ib. $\$ 1.75$, postpaid.

47. Pride of Wisconsin. ( 90 days.) A delicious melon for the home-garden and near-by markets. Its fruits are oval, weigh about $33 / 4$ pounds, and the coarsely netted rind is pearly gray. The thick orange flesh is solid, very sweet and of fine flavor. Pkt. 10c.; oz. 20c.; 1/4lb. 60c。; lb. $\$ 1.75$,

54. Tip Top. ( 90 days.) Large, slightly oval fruits mature yellow with delicious, sweet, bright salmon flesh. Pkt. 10c.; oz. 20c.; $1 / 4 \mathrm{lb}$. $50 \mathrm{c}$.; Ib. $\$ 1.50$, postpaid.

\section{WATERMELON}

One ounce will plant 30 hills: 4 pounds, an acre

Prices include postage on pkts., ozs., $1 / 4 \mathrm{lbs}$, and lbs.

Culture. Same as muskmelon except that they should be planted 8 to 10 feet apart each way.

149. Dixie Queen. (85 days.) "Best-inGarden" variety. This Southern favorite is a medium-sized, oval-round melon attractively striped dark green on light green with thin but tough rind. The flesh is sparkling red, frrm, juicy and sweet. White seeds. Melons average 30 pounds and ship well. Pkt. 10c.; oz. 15c.; 1/4Ib. 45c.; Ib. $\$ 1.15$, postpaid.

81. Florida Giant or Cannonbalt. (90 days.) Vigorous, very productive vines with nearly round, dark green fruits averaging 40 pounds each. The flesh is red, frrm and of excellent quality. Seed mottled dark brown. It ships well. Pkt. 10c. oz. $15 \mathrm{c}$; $1 / 1 \mathrm{lb} .45 \mathrm{c}$; Ib. $\$ 1.25$, postpaid.

175. Georgia Rattlesnake. (90 days.) Elongated gray-green fruits with very dark green stripes. Deep scarlet flesh of unsurpassed flavor. Seeds are white with black tips. Pkt. 10c.; oz. 15c; ; 1/4Ib. 35c.; Ib. 90 c., postpaid.

52. Hawkesbury. ( 85 days.) A wilt-resistant melon from Australia. The oblong fruits are light gray with fine green veining. Flesh dark pink, of good quality. Brownish black seeds. Rind is tough making it a safe shipper. Pkt. 10c.; oz. 15c.; 1/4lb. 45c.; lb. $\$ 1.15$, postpaid.

144. Improved Florida Favorite. (85 days.) Green skin with irregular dark green stripes. Bright red flesh of extra sweetness. White seed. A good shipper. Pkt. 10c.; oz. 15c.; 1/4lb. 35c.; lb. 90c., postpaid.

304. Irish Grey. (90 days.) Long, oval, light gray fruits with bright red flesh, crisp and sweet. White seed. Tough, hard rind insures its shipping qualities. Pkt. $10 \mathrm{c}$; $0 \mathrm{z}$. $15 \mathrm{c}$.; $1 / 4 \mathrm{lb}$. $35 \mathrm{c}$.; Ib, $90 \mathrm{c}$, , postpaid.

\section{Stone Mountain. (90 days.) A high-} quality shipping melon liked by home gardeners. Fruits are oval-round and green with indistinct veining. Flesh is rich green with indistinct veining. Fine-grained and very sweet. Seed white with black edges. On good melon ground they weigh from 30 to 40 pounds each. Pkt. $10 \mathrm{c}$.

64. Tom Watson.

(90 days.) The melon of The attractive fruits are long cylinders of dark green with deep red, frrm, crisp flesh of good flavor. Brown seed. A splendid keeper. Pkt. 5c.

132. Wondermelon or Kleckley Sweet Improved. (85 days.) This improved strain has the same delicious sweet red flesh of the old favorite Kleckley's Sweet. The rind is rather thin but reasonably tough, insuring carrying for short hauls. Large, dark green, oblong fruits averaging 30 to 40 pounds. White seed. Pkt.

343. Preserving Citron. (95 days.) Medium size, uniformly round, used only for preserves or pickles. Color dark green, distinctly striped and marbled with light green. Flesh white and solid, but not at all suitable for eating raw. Seed red.

Pkt. 10c.; oz. 15c.; 1/4 Ib. 35c.; lb. $90 \mathrm{c}$., postpaid.

\section{MUSHROOM SPAWN}

Mushrooms have been grown with success in cellars, under benches, in barns or wherever the temperature of 50 degrees can be kept up through the winter. Location should not be too damp or subject to sudden changes in temperature. No direct sunlight should fall on the bed. Fresh horse-manure is the best medium for Mushroom culture.

Tobacco-Stem Spawn. This new type spawn, grown on crumbled tobacco stems, manure than the old-type brick or manure spawn.

8-oz. can with instructions booklet, $\$ 1.00$.

\section{MUSTARD}

One ounce will sow 100 feet of row; 3 pounds broadcast, an acre, or 1 to 2 pounds if drilled in rows

Mustard "greens" are tasty and highly nutritious, being an excellent source of vitamins $A$ and $C$ and supplying both calcium and iron.

Culture. Sow in February, March or April for spring use and in August and September for fall use. Sow in rows and thin to stand 6 inches apart. The "greens" are best if soil is rich and kept well watered.

170. Chinese. (45 days.) Large, broad, smooth leaves of sweet, pungent flavor. A heavy producer of leaves which are delicious when boiled like spinach. Pkt. $5 \mathrm{c}$. oz. 20c.; $1 / 4$ lb. 50c.; lb. $\$ 1.50$, postpaid.

143. Fordhook Fancy. ( 40 days.) A vigorous heavy yielder of dark green, plumelike leaves of mild flavor. Pkt. $5 \mathrm{c}$.; oz. 25c.; 1 $1 / \mathrm{Ib} .65 \mathrm{c}$.; lb. $\$ 2.00$, postpaid.

130. Southern Giant Curled. (35 days.) A popular Mustard in the South. Plants are strong-growing and produce long, wide, yellowish light green leaves, heavily crumpled and curled at edges. Excellent flavor. Can be planted in fall for early spring salad. Pkt. 5c.; oz. 20c.; 1/4Ib. 50c.; Ib. $\$ 1.50$, postpaid

303. White Seed. (40 days.) Named for its light yellow seed. The young leaves are mild and tender, making a frne salad vegetable. Pkt. 5c.; oz. 20c.; 1/4lb. 50c.; Ib. $\$ 1.50$ postpaid.

139. Tendergreen or Mustard Spinach. (45 days.) Described on page 23. Pkt. $5 \mathrm{c}$. oz. $20 \mathrm{c}$; $1 / 4 \mathrm{Ib}$. $50 \mathrm{c}$; ; Ib. $\$ 1.50$, postpaid.

\section{OKRA}

One ounce will sow 50 feet of row 8 pounds, an acre

Prices include postage on pkts., ozs., $1 / 4$ lbs., and lbs.

Okra provides vitamins $\mathrm{A}$ and $\mathrm{C}$ in helpful quantities and its green pods are popular in stews, etc.
Culture. Okra seed requires warm ground to germinate and should not be 1 inch deep in rows, in rich ground. Thin to stand 15 to 18 inches apart in the row. Keep 154. Dwarf Green Prolific. (50 days.) A very early variety with dwarf, compact plants which are free producers of short, cods dry roadily for winter.

kt. 5c.; oz. 10c.; 1/4lb. 25c.; lb. 60c.,

. Improved Long Green. (60 days.) long pods which remain tender a long time and are free from hard ridges. Pkt $5 \mathrm{c}$; $0 \mathrm{z} .10 \mathrm{c}$; $1 / 4 \mathrm{lb} .25 \mathrm{c}$; Ib. $60 \mathrm{c}$., postpaid. 189. Perkins' Mammoth Long-Podded. 56 days.) The entire plant is covered with pods from top to within 3 inches from ground. These slim, intensely green pods are from 7 to 8 inches long and retain 25 c.; Ib. 60c., postpaid.

\section{ONIONS}

One ounce will sow 100 feet of row; 5 pounds, an acre

Prices include postage on pkts., ozs., $1 / 4 \mathrm{lbs}$., and lbs.

Culture. For sets sow the seed as early as possible in the spring, very thickly in drills. As soon as the tops die off in summer, remove them to a dry, airy place, and early in the following spring replant by placing the sets in shallow drills, 12 inches apart, Onions obtained by this process are of large size early in the season. May also be grown to full size during the first season by sowing thinly in drills 1 foot apart and about $1 / 4$ inch deep in March or early in April, in strong land, well manured, and thinning them out to 3 to 4 inches apart in drills. They thrive in a strong, rich, deep, loamy soil. By sowing Onion seed in frames in February and March, and transplanting in April, Onions of immense size can be obtained. 202. Danvers Flat Yellow. (110 days.) A hardy, easily grown Onion of brownish yellow. Splendid winter keeper and variety widely grown for sets. Pkt. $10 \mathrm{c}$. Oz. $65 \mathrm{c}$; $1 / 1 / 4 \mathrm{Ib} . \$ 1.50 ;$ Ib. $\$ 5.50$, postpaid.
206. Large Red Wethersfield. (100 days.)

An early-maturing Onion with large, flattened, thick bulbs, the skin purplish red, the solid flesh purplish white. A heavy producer in poor soils. Pkt. $10 \mathrm{c}$.

224. Prizetaker. (100 days.) A mammoth Yellow Globe derived from the huge Spanish Onion, the largest and hand somest Onion in cultivation. It can be grown to full size from seed. Mild flavor. Pkt. 10c.; oz. 65c.; 1/4l Ib. \$1.65; lb. $\$ 6.00$,

225. Southport White Globe, (110 days.) Of true globe form, the Onions are 2 to
$21 / 2$ inches in diameter, with a thin, delicate skin of purest paper whiteness. The flesh is crisp, fne-grained, snowy white in color and very mild flavor. Pkt. 10c.; oz. 65c. 1/4lb. \$1.65; Ib. $\$ 6.00$, postpaid.

293. White Portugal. (100 days.) An allpurpose, mild White Onion, used for sets,

pickling, green bunching and storage.

kt. 10c.; oz. 70c.; 1/4lb. $\$ 1.75 ; 1 \mathrm{~b} . \$ 6.50$, postpaid. 


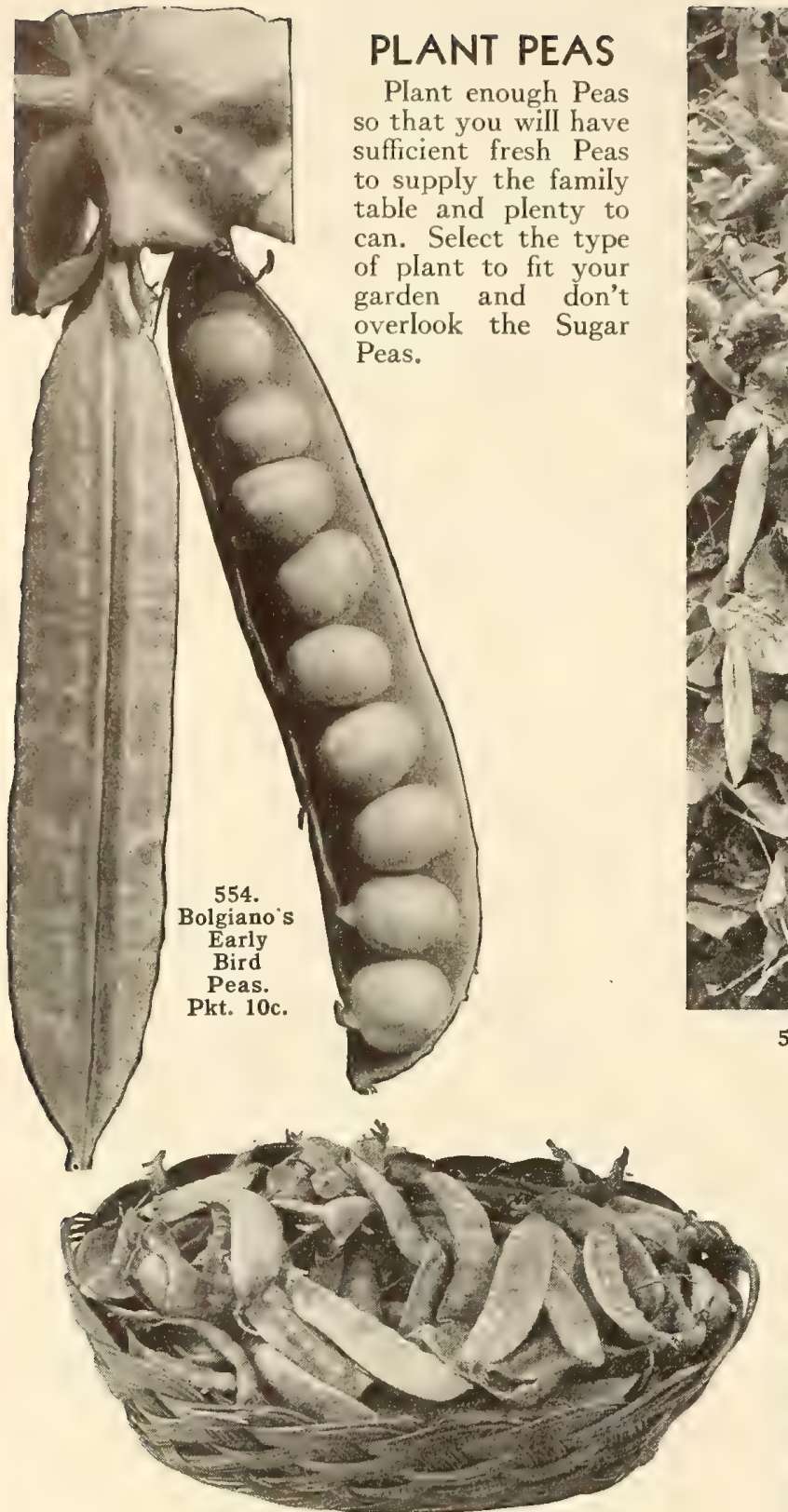

531. Dwarf Gray Sugar Peas. Pkt. 10c.

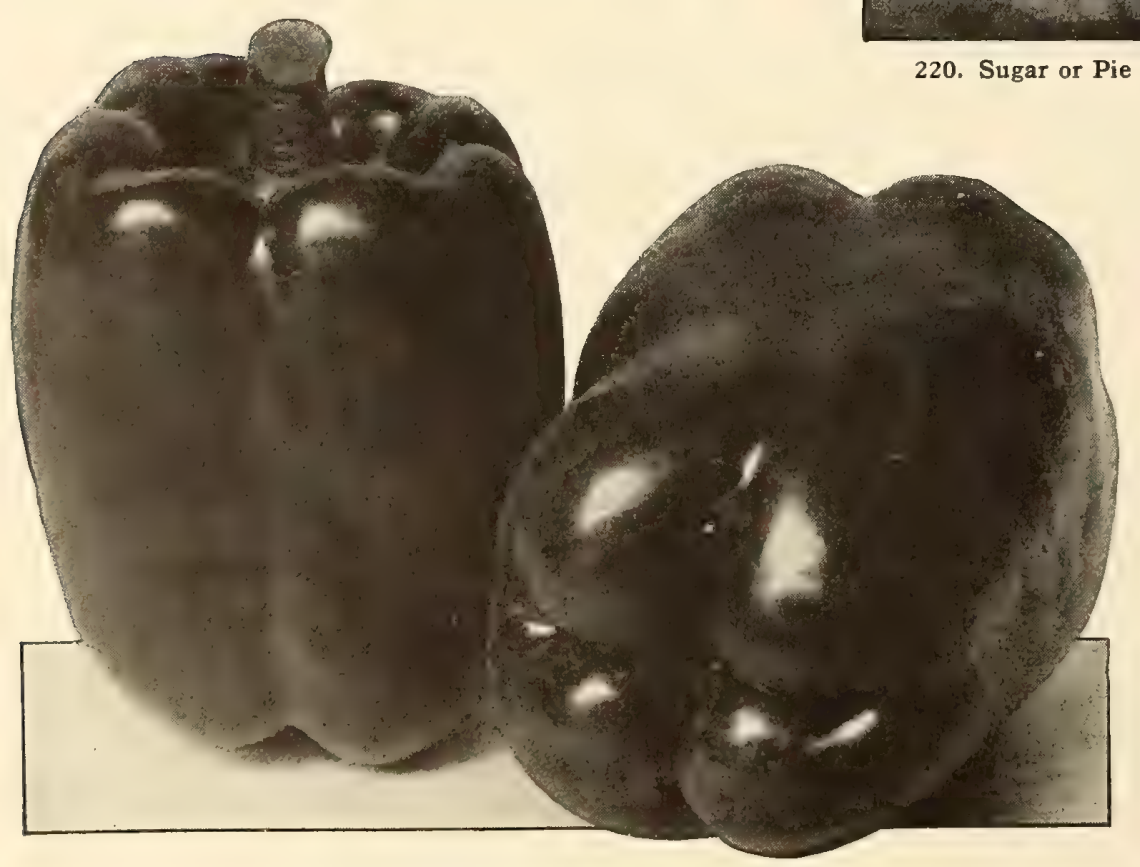

195. California Wonder Peppers. Pkt. 10c

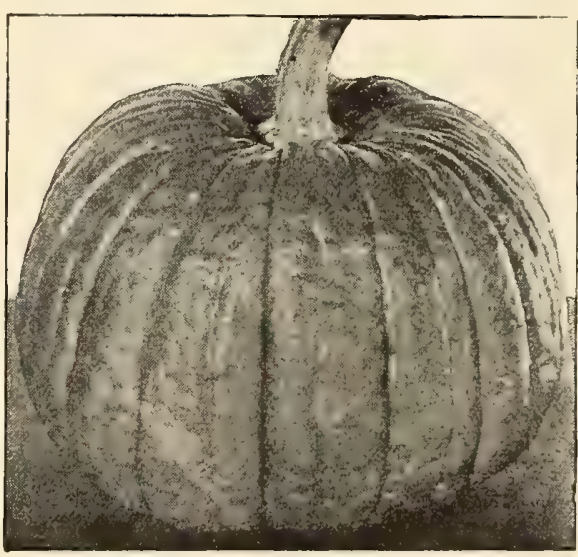

220. Sugar or Pie Pumpkin. Pkt. 5c.

\section{DO YOU KNOW PEPPERS?}

There are several types of Peppers so be careful in selecting. Most families will want the large sweet kinds for stuffing, frying and mixed pickles, while the small hot types will find plenty of uses. Read the descriptions carefully.

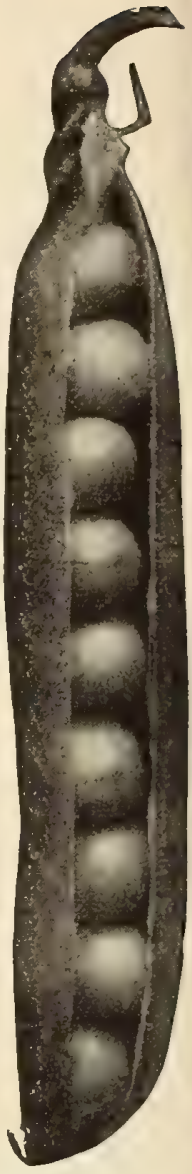

568. Ameer or Long-podded Alaska Peas. Pkt. 10c.

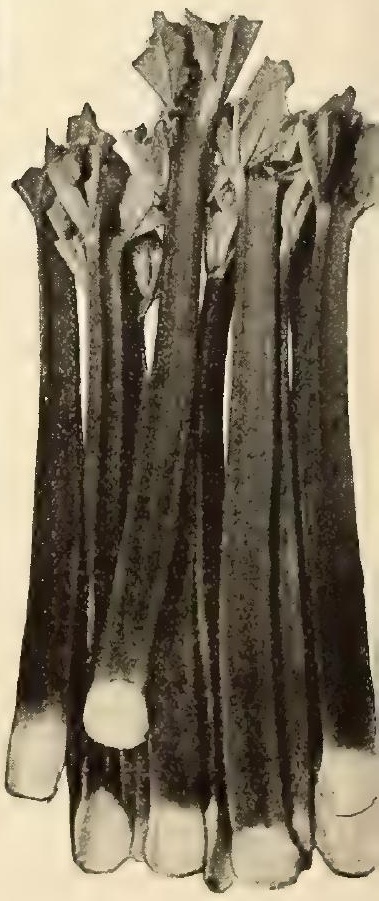

203. Victoria Rhubarb. Pkt. 10c. 


\section{ONIONS, continued}

85. White Silverskin. (100 days.) "Bestin-Garden" variety. This famous Onion retains its great popularity. Its delicate and mild flavor, its shapely form and size, and its pure color make it a most desirable variety for the table, for the market and for shipping. Onion sets are extensively grown from this sort, and from these sets full-size Onions are grown as early as June and July. The Onion sets and large Onions are used for pickling purposes because of their clean, silvery white color.

Pkt. 10c.; oz. 70c.; 1/1b. $\$ 1.75$; Ib. $\$ 6.50$, postpaid.

296. Yellow Globe Danvers. (110 days.) An oval-shaped, straw-colored Onion which is a splendid keeper. Flesh white, crisp and mild. Pkt. $10 \mathrm{c}$.; oz. $65 \mathrm{c}$.; $1 / 4 \mathrm{lb}$. $\$ 1.50$; Ib. $\$ 5.50$, postpaid.

\section{ONION SETS}

\section{Onion Sets by Mail}

We will send by mail postpaid either Yellow or White Onion Sets at 1/2lb. (about $1 \mathrm{pt}$.) 30c.; 1 lb. (about I qt.) 40c., safely packed. We Supply Onion Sets in Any Quantity up to Carloads.

White Silverskin

Yellow Danvers

Write for latest prices. Prices subject to market changes.

\section{PARSLEY}

One ounce will sow 200 feet of row 3 to 4 pounds, an acre.

Prices include postage on pkts., ozs., $1 / 4 \mathrm{lbs}$., and lbs.

Culture, Parsley needs a mellow, rich soil and the seed is slow to germinate. A good plan is to soak the seed a few hours in warm water and then plant $1 / 2$ inch deep and thin plants to stand 8 to 10 inches apart. If the leaves of curly varieties are all cut off when they are 3 inches talI, growth will be better. Liberal cutting of Parsley improves quality. For winter use move plants to a coldframe or Iight cellar, or a supply can be potted in 6 -inch flower-pots and grown in a kitchen window,

\section{Emerald or Extra Curled Dwarf.} (70 days.) The beautifully curled bright green leaves are very tender. Long stems make it easy to bunch for market. An attractive garnish variety. Pkt. $5 \mathrm{c}$; oz. 15 c.; 1 Ib. 40 c.; lb. $\$ 1.25$, postpaid.

106. Market Gardeners' Best Triple Curled. (70 days.) "Best-in-Garden" variety. Robust, free-growing plants which are improved by severe cutting. The large, dark green leaves are beautifully curled. Plants stand heat and cold better than most varieties. Pkt. 10c.; oz. $15 \mathrm{c}$.; $1 / 4 \mathrm{Ib} .40 \mathrm{c}$; Ib. $\$ 1.25$, postpaid.

341. Plain or Single. (70 days.) The very dark green leaves are flat, deeply cut but not curled and are principally used for flavoring soups and stews, as the flavor is strong. Can be dried and bottled fo winter use. Pkt. 5c.; oz. 15c.; 1/4 Ib. 35c.; Ib. $\$ 1.15$, postpaid.

\section{PARSNIP}

One ounce will sow 200 feet of row; 3 to 4 pounds, an acre.

Prices include postage on pkts., ozs., $1 / 4$ lbs., and lbs.

Culture. Parsnips prefer a rich deep sandy loam. Avoid stony ground and new manure. Sow as early as possible in rows, covering $1 / 2$ inch deep, and press soil down frrmly. Thin to stand 5 inches apart in row. Leaving the roots in ground over winter improves the flavor.

83. Hollow Crown or Improved Sugar. (100 days.) The standard Parsnip everywhere. Long smooth roots with hollowcrowned, broad shoulders make it easy to dig. Flesh is tender and of excellent flavor. Pkt. 5c.; oz. 20c.; 1/4lb. 50c.; Ib. $\$ 1.50$, postpaid

\section{PEAS}

One to two pounds will plant 100 feet of row; 120 pounds, an acre.

Prices include postage on pkts., lb., 2 lbs.,

WRINKLED VARIETIES. 14-1b. and 56-lb. lots, not postpaid

SMOOTH OT SEMI-WRINKLED VARIETIES. 15-1b. and 60-1b. lots not postpaid.

Peas are not only delicious food but they ontain iron and vitamins $A, C$ and $B_{1}$ Every garden needs lots of Peas.

Culture. Peas mature earliest in light, rich soil. For general crop use a rich, deep loam or one inclining to clay. When grown in garden sow in double rows 6 to 8 inches apart; the rows 2 to 4 feet apart. Commence sowing the extra-early varieties as early as the ground can be worked in February or March; plant for a succession every two weeks until June, then discontinue until the middle of August, when a good crop may be secured by sowing extra-early and early sorts for fall use. They should be kept clean and earthed up twice during the growth. The wrinkled varieties are not as hardy as the small, round sort and if planted early should have a dry soil or they are liable to rot in the
ground. They are, however, the sweetest and best-flavored varieties. The dwarf varieties are best suited for small gardens.

\section{Extra-Early Dwarf Varieties}

561. American Wonder. Wrinkled.

days.) The 12-inch vines are very productive. Pods contain 5 to 8 tender sweet Peas. Pkt. 10c.; lb. 35c.; 2 lbs. 60c.; 5 lbs. $\$ 1.30$, postpaid

14 Ibs. $\$ 2.80 ; 56$ lbs. $\$ 10.00$, not postpaid 554. Bolgiano's Early Bird. Semi-wrinkled. (60 days, "Best-in-Garden" variety. This wonderful semi-wrinkled dwarf variety can be planted as soon as the ground car be worked as they do not rot in the ground like fully wrinkled Peas. The dwarf vigorous vines measure 18 inches and carry enormous crops of large, beautiful deep green pods, 4 to 5 inches long, filled with 8 or 9 large Marrow Peas of fine variety for the market gardener. For the home gardener it is unsurpassed. Pkt. $10 \mathrm{c}$. Ib. 35 c.; 2 Ibs. 60 c.; 5 Ibs. $\$ 1.40$, postpaid. 15 lbs. $\$ 3.30 ; 60$ lbs. $\$ 12.00$, not postpaid. The 18-inch vines have dark green foliage and bear dark green pods about 4 inches long, containing 7 or 8 succulent Peas.

Pkt. 10c.; Ib. 35c.; 2 lbs. 60c.; 5 lbs. $\$ 1.40$, postpaid.

14 lbs. $\$ 3.10$; 56 lbs. $\$ 11.25$, not postpaid. 558. Laxton's Progress. Wrinkled. (60) days.) The 18-inch vines are very prolific, bearing large pods containing 7 to 9 large Peas of good quality. Pkt. 10c.; Ib. 35c.; 2 Ibs. 60 c.; 5 lbs. $\$ 1.40$, postpaid.

14 Ibs. \$3.10; 56 lbs. \$11.25, not postpaid 562. Little Marvel. Wrinkled. (62 days.) The stocky, dwarf vines, about 18 inches tall, are generous producers of nearly round, square-end pods holding 7 or 8 Iarge, deep green Peas. Pkt. 10c.; lb. 35c.; 2 lbs. 60 c.; 5 Ibs. $\$ 1.30$, postpaid.

14 Ibs. $\$ 2.80$; 56 Ibs. $\$ 10.00$, not postpaid. 559. Nott's Excelsior. Wrinkled. (60 days. Very similar to American Wonder, which see. Pkt. 10c.; Ib. 35c.; 2 Ibs. 60c.; 5 lbs. $\$ 1.30$, postpaid

14 Ibs. $\$ 2.80 ; 56$ lbs. $\$ 10.00$, not postpaid. 560. Premium Gem. Wrinkled. (62 days.) The 18-inch plants bear plump pods containing 6 or 7 Peas of fine quality. Pkt. 10c. Ib. 35 c.; 2 Ibs. 60 c.; 5 lbs. $\$ 1.30$, postpaid 14 Ibs. $\$ 2.80 ; 56$ Ibs. $\$ 10.00$, not postpaid

\section{PLANET JR. SEEDERS}

For best results sow your vegetable seed accurately with a Planet Jr. Seeder. It saves time. It saves work. It saves seed. See page 58.
Extra-Early Tall Varieties 564. Alaska. Smootb.

$21 / 2$-foot witt-resistant plant dark green pods which contain 6 to 8 Peas of good quality. Pkt. $10 \mathrm{c}$;

15 lbs. $\$ 2.70 ; 60$ lbs. $\$ 9.60$, not postpaid. Smootbeer or Long-podded Alaska. feet tall bear heavy crops very early. The large pods contain 7 or 8 Peas of fine eating quality. Pkt. 10c.;

15 lbs. $\$ 3.00: 60$ lhs. $\$ 10.75$, not postpaid.

563. First and Best. Smoolb. (58 days.) An extra-early Pea of very frne flavor. Ib. $35 \mathrm{c}$.; 2 lbs. $60 \mathrm{c}$; 5 lbs. $\$ 1.20$, postpaid. 15 lbs. $\$ 2.70 ; 60$ Ibs. $\$ 9.60$, not postpaid. 567. Gradus or Prosperity. Wrinkled. (58 days.) The robust plants grow 3 feet mense Peas which remain sweet and tender a long time after they are ready to pick.
Pkt. 10c.; [b. 35c.; 2 Ibs. $60 c_{\text {c }} ; 5 \mathrm{Jbs} . \$ 1.40$, postpaid.

14 lbs., $\$ 3.10$; 56 lbs. $\$ 11.25$, not postpaid. 555. Thomas Laxton. Wrinkled. (57) days.) Vines quickly grow $31 / 2$. wet tall large tender Peas of unexcelled flavor. Its extra earliness make this popular for market and canning, while $60 \mathrm{c}$; 5 lbs. $\$ 1.40$, postpaid. 14 lbs. $\$ 3.10$; 56 lbs. $\$ 11.25$

\section{General Crop Varieties}

\section{Telephone, Wrinkled.}

A dependable variety growing about 4 feet tall and bearing 5 -inch pods containing 8 to 10 Pe

$14 \mathrm{lbs}$

\section{Edible-Podded or Sugar Peas}

531. Dwarf Gray Sugar.

Grows to height of $21 / 2$ to 3 feet; bears profusion of medium broad pods. Should beans. Pods, when cooked, are very sweet and tender. Pkt. 10c.;

2 Ibs. 60 c.; 5 lbs. $\$ 1.30$, postpaid.
15 lbs. $\$ 3.00 ; 60$ Ibs. $\$ 10.75$, not postpaid.

\section{PEANUTS}

Peanuts grow on any soil, but are more easily harvested on light soils. Plant 35 pounds of shelled nuts or 50 pounds unE. Peanuts require lime, phosphate and potash. Use Gold Tag 2-8-10 Fertilizer, 200 to 400 pounds per acre.

Virginia Jumbo or Virginia Runner. good variety for light sandy soil where they produce enormous bright, attractive nuts, with few pops.

Lb. 25c, not postpaid.

\section{PEPPERS}

One ounce will produce about 1200 plants.

Prices include postage on pkts., ozs.

$$
1 / 4 \mathrm{lbs} \text {., and } 1 \mathrm{bs} \text {. }
$$

Peppers furnish both $A$ and $C$ vitamins, being especially high in vitamin C. Pepper types vary as do their uses. Housewives find all types important in adding variety to the diet.

Culture. Sow in hotbeds in March April or outdoors in a sheltered position in May. Transplant to 18 inches apart in rows in mellow, rich groun

274. Bell or Bull Bose.

dium-sized fruit, mild except ribs which are pungent. A dependable early. Pkt. $10 \mathrm{c}$. oz. 30c.; 1. Ib. 80c.; lb. $\$ 2.75$, postpaid. 


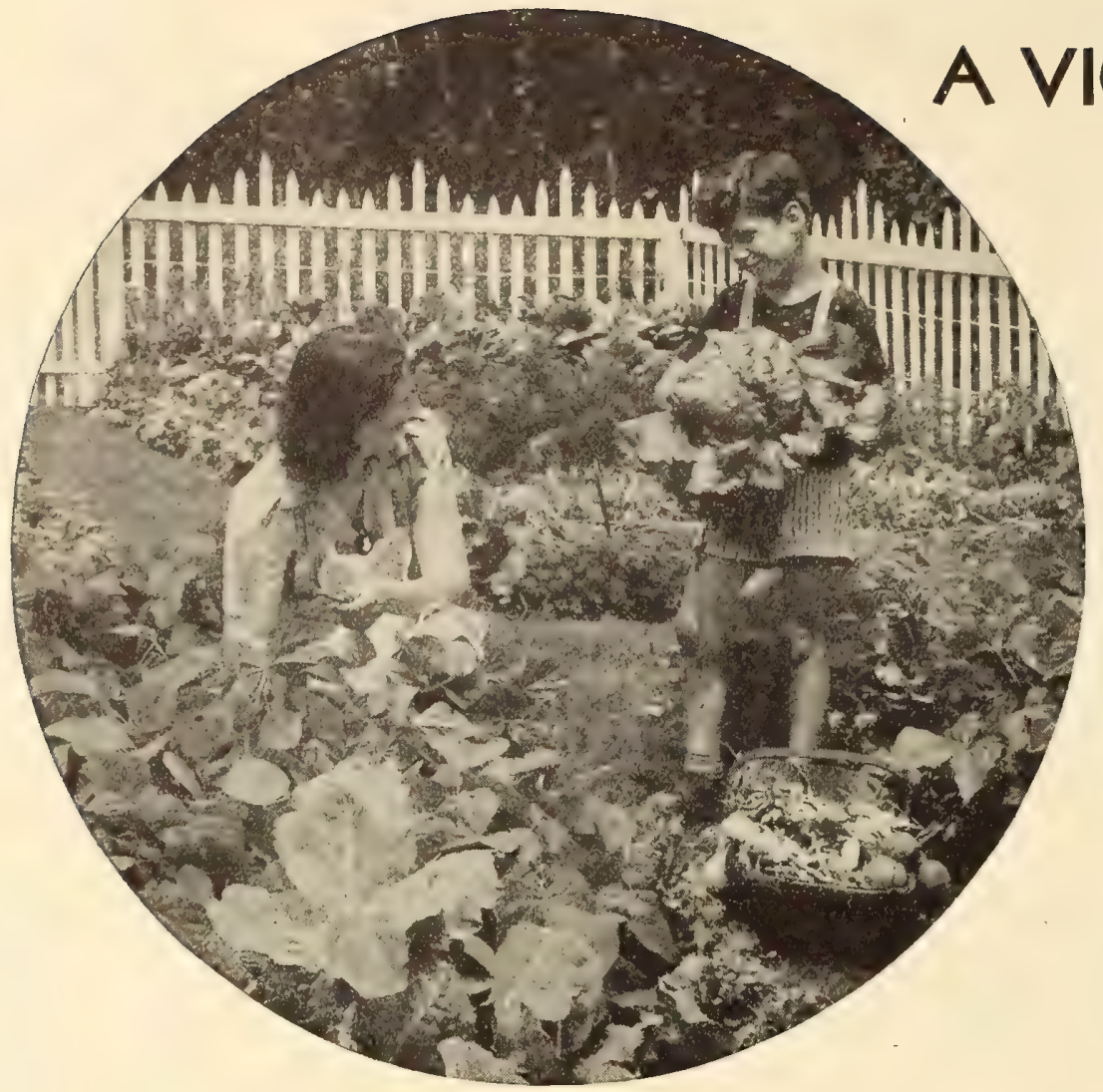

\section{for \\ EVERYONE}

A vegetable plot within easy reach of your kitchen door will assure you of fresh green vegetables all summer. And you will have the extra satisfaction of knowing that your gardening is helping to save needed food and transportation facilities for our fighting men.

It is not necessary to have access to a large piece of ground in order to have a garden. A small patch well cared for will bring far better returns than a large planting that is neglected.

The first vegetable book to be illustrated in full color, "Vegetable Gardening in Color," by Daniel J. Foley, has just been published. It will be very useful to the home gardener, and well worth buying. (We will send it to you. Price, $\$ 2.50$.)

"What to plant?" is a question confronting the gardener, especially the beginner, who is unfamiliar with the different varieties. To solve the problem for you, we have made up a collection of vegetables that are the backbone of the garden and favorites on most tables. Turn to page 5, where you will find listed the varieties comprising the collection. By ordering it, you will save both time and money. $\$ 1.75$ worth of seed for $\$ 1.25$.

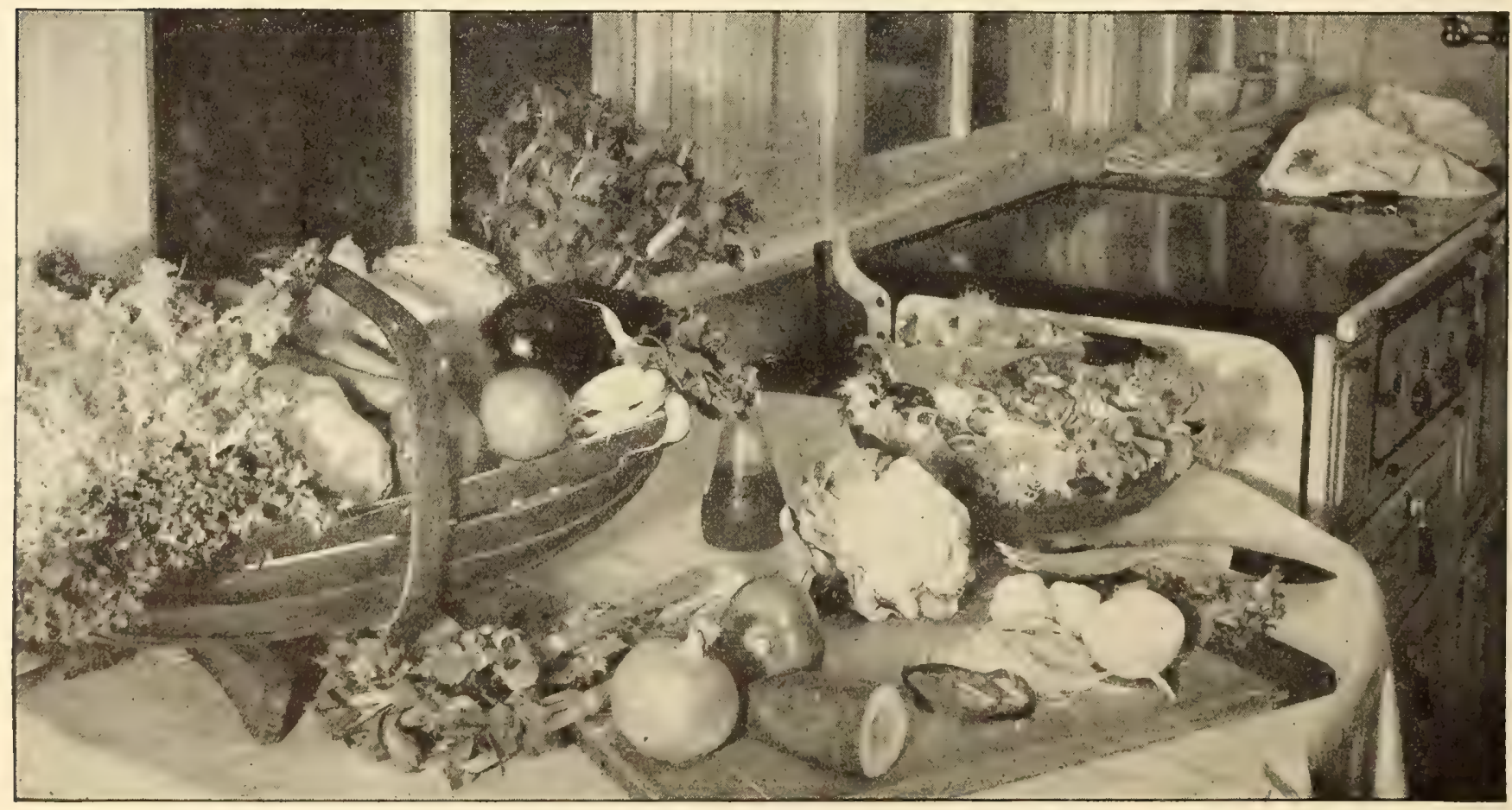

A fresh green salad every day will give your family the extra vitamins they need.

But don't say to them, "Eat it; it's good for you." Just say, "It's good," and they will agree. 


\section{PEPPERS, continued}

195. California Wonder. (120 days.) "Best-in-Garden" variety, An outstandous plant and many blocky fruits with thick, crisp flesh, sweet and spicy but thick, crisp flesh, sweet and spicy but without a bite. Housewives prize this
Pepper for stuffing and serving whole; with its 4 points it will stand upright on the table and is a handsome Pepper. Pkt. 10c.; oz. 40c.; $1 / 4 \mathrm{lb}$. $\$ 1.15$; Ib. $\$ 4.00$ postpaid.

174. Chinese Giant. (120 days.) An immense $4 \times 4$-inch Pepper with 4 or 5 irregular points. Fruits are much ribbed and deep green in color, changing to brilliant scarlet. The flesh is mild and sweet. Pkt. 10c.; oz. 40c.; 1/4 Ib. \$1.25; lb. $\$ 4.50$, postpaid.

253. Long Red Cayenne. (120 days.) A favorite hot Pepper for canning, for mixed pickles and for drying. Plants are large and heavy producers. The tapering fruits are deep green changing to brilliant red when mature. Pkt. 10c.; oz. 35c.; 1/4 lb. 90 c.; Ib. $\$ 3.25$, postpaid.

306. Pimento. (130 days.) Conical fruits $31 / 2 \times 2 \frac{1}{4}$ inches are borne on large erect plants in profusion. Fruits are bright scarlet in color and the thick flesh is tender and sweet. Pkt. 10c.; 0z. 30c.; 1/4l Ib. 75c.; lb. $\$ 2.50$, postpaid.

266. Red Chili. (135 days.) Requires a long season and plants should be started early in a hotbed. Plants grow only about 18 inches tall but are very productive. Fruits are deep red cones when mature and
are exceefingly pungent. Pkt. 10c.; oz. 40c. 1/4lb. \$1.15; Ib. \$4.00, postpaid.

283. Ruby King. (110 days.) Large slightly tapered fruits to 5 inches long. Flesh is thick, mild and sweet. Pkt. 10c.; oz. 30c,; $1 / \mathrm{Ib}, 75 \mathrm{c}$.; Ib. $\$ 2.50$, postpaid.

330. World-Beater. (110 days.) Fruit large, oblong, commonly 5 inches long and $31 / 2$ inches in diameter, deep green, sweet. Pkt. 10c.; oz. 30c.; 1/4I Ib. 85c.; Ib. $\$ 2.75$, postpaid.

\section{POTATOES}

Our Seed Potatoes are grown in the cold North in the famous Potato district of Houlton, Maine, and are the finest obtainable today. Experience has shown that northerngrown Potatoes taken a few hundred miles south produce up to double the crops of home-grown seed of the same varieties. Bolgiano's selected Maine Seed assures not only a larger crop but an earlier one of Potatoes of the highest quality.

We offer only varieties which have proved most satisfactory in our customers' frelds and gardens after exhaustive trials.

We are prepared to ship at any time but must warn that shipments ordered made during severe cold weather travel solely at purchaser's risk.

Chippewa. A U. S. Department of Agriculture origination maturing a few days later than Irish Cobbler. It is diseaseresistant and a heavier yielder than Cobbler. A smooth Potato with light skin.

Green Mountain. Uniformly shaped, obIong tubers with creamy white skin. Pure white flesh of excellent quality. Free from both blight and rot, it is a good yielder.

Irish Cobbler. This great extra-early Potato is smooth, has creamy white skin and white flesh of top eating quality. A vigorous grower, the tubers ripening uniformly and keeping weli.

Katahdin. Handsome, shallow-eyed, whiteskinned tubers mature right after Green Mountain. Desirable cooking qualities. Disease-resistant and does best on light soils.

See enclosed pink sheet for latest Potato prices.
Red Bliss Triumph or Improved Red Bermuda. One of the earliest varieties grown. Popúlar because of its great productiveness, handsome color, and retance to disease.

Spaulding Early Rose. Pinkish, longish tubers with white flesh of highest quality
Popular everywhere as a midseason Potato

\section{POTATOES FOR JUNE AND} JULY PLANTING

We carry in cold storage all the leading varieties so as to have them in sound, vigorous and unsprouted condition. Write for prices.

\section{Sweet Potatoes}

Culture. Don't wait for a rain or Harrow your ground well before laying it oft then throw up the ridges higher than you want them, and if the soil is very dry, allow 2 or 3 days for the moisture to rise. Then knock off the top of the ridge just ahead of planting; make a mud batter with water and clay loam, or better, with the addition of fresh cow-dung, about as thick as cream; dip the plants, in hands of about 20 , into this, so that mud clings to them.

Plants ready in May and should be planted May or June.

Big-Stem Jersey. Heavy crops of uniform tubers of good size and qualit

Nancy Hall. Well-known and popular

\section{PUMPKIN}

Three pounds will plant an acre.

Prices include postage on pkts., ozs. $1 / 4 \mathrm{lb}$, and $\mathrm{lbs}$

Culture. Pumpkins should be planted in hills ( 4 seeds to a hill) 8 to 10 feet each wa. and varieties should be kept separate. They require about the same conditions as cucumbers and melons except that farmer

158. Connecticut Field or Large Yellow. (115 days.) A general-purpose Pumpkin for pies, canning or stock-feed. The partly globe-shaped orange fruits weigh 15 to 30 pounds each. Pkt. 5c.; oz. 10c.; $1 / 4 \mathrm{Ib}$ 25c.; Ib. $75 \mathrm{c}$, postpaid.

181. Green Striped Cushaw. (112 days.) A creamy white crookneck Pumpkin Flesh is lighting 14 to 16 pounds sweet. Pkt. 10c.; oz. 15c.; $1 / 4 \mathrm{Ib}, 35 \mathrm{c}$. lb. $\$ 1.00$, postpaid

245. King of the Mammoths or Potiron. (120 days.) Averaging 60 pounds, specithough largely used for stock-feed the quality is good and makes a splendid pie. Pkt. 10c.; oz. 15c.; 1/1 Ib. 40c.; Ib. $\$ 1.15$, postpaid.

126. Large Sweet Cheese. (108 days.) A flat, cheese-box Pumpkin with lemoncolored skin and thick orange-yellow flesh of fine quality. Fruits weigh 10 to 15 pounds each. Pkt. 5c.; oz. 10c.; 1/4Ib. 25c. b. 75c., postpaid.

220. Sugar or New England Pie. (108 days.) The ideal home Pumpkin weighing 6 to 8 pounds each. The roundish fruits are deep orange in color with bright orange, thick, sweet, dry flesh of high quality.

Pkt. 5c.; oz. 15c.; 1/4lb. 35c.; lb. 90c.

197. Sweet Potato. (110 days.) Creamy white, pear-shaped fruits weighing 12 Sweet Potato flavor. Pkt. 10c.; oz. 15c.

75. Yellow Winter crookneck. (100 days.) The yellow fruits are about 2 feet long with curved necks. Flesh is thick and meaty. Pkt. 5c.; oz. 15c.; 1/4 Ib. 35c ; Ib. $\$ 1.10$, postpaid.

\section{RADISHES}

One ounce will plant 100 feet of row; 8 to 12 pounds, an acre.

Prices include postage on pkts., ozs. $1 / 4 \mathrm{lbs}$., and lbs.

Culture. Radishes soil and must have ple Sow seed for Winter Radishes in late July and August. These should be dug before frost and stored in a cellar.

\section{Early Varieties}

72. Bolgiano's No. 2 Scarlet Globe. days.) "Best-in-Garden" variety. A handsome small oval Radish of brilliant scarlet lesh is tender, juicy and mild. Equafly good for garden or forcing, it commends tself to both the amateur and the marke

316. Crimsen Giant. (28 days.) The large roots are globes to $11 / 2$ inches, deep is of superior quality. Pkt.10c; ; oz. 15c.; 4 lb. 30c.: Ib. $90 \mathrm{c}$ postpaid

208. French Breakfast. ( 25 days.) Obong roots of rich scarlet with white base. Good quality if pulled early. Pkt. 10c. 95. Improved Long Scarlet Short-Tip. Pkt 10c.

91. Scarlet Turnip White-Tip.

small white tip. Flesh white, crisp, and nild. Skt. 5c.; oz. 15c.; 1/4 Ib. 30c.; Ib. 90c.

278. White Icicle.

Trans-

with brittle flesh of mild inviting flavor. Remains in good condition a long time after ready to pick. Pkt. 5c.; oz. 15c. $1 / 4$ Ib. 30c.; Ib. 90c., postpaid.

\section{Summer Varieties}

118. White Strasburg. (39 days.) Fiveinch white roots with crisp, white, slightly ngent flesh. Continues marketable condition a long time after first ready to pick. Pkt. 10c; oz. 15c. $1 / 4$ Ib. 30c.; Ib. $90 \mathrm{c}$., postpaid.

\section{Winter Varieties}

157. China Rose or Scarlet China. (52 days.) Roots are 4 to 6 inches long and 2 inches through, bright rose-red in color. The firm white flesh is pleasingly pungent, Pkt 10c.; oz. 15c.; 1/4 Ib. 30c.

90. Long Black Spanish. (58 days.) Cylindrical, somewhat roughened, blackskinned roots with solid, white, pungent Pt. 10c.

78. White Chinese or Celestial

The mildest a an be used when only 3 inches long but they should be stored. Flesh is white. crisp and quite mild. Pkt. 10c.;

RAPE

57. Dwarf Essex. A hardy
smooth-leaved
is very sweet and
from seeding.
early spring through the fall.
$\mathrm{O}_{2}, 5 \mathrm{c} ; 1 \mathrm{1}, \mathrm{lb}, 15 \mathrm{c} ;$ ib. $25 \mathrm{c}$ 


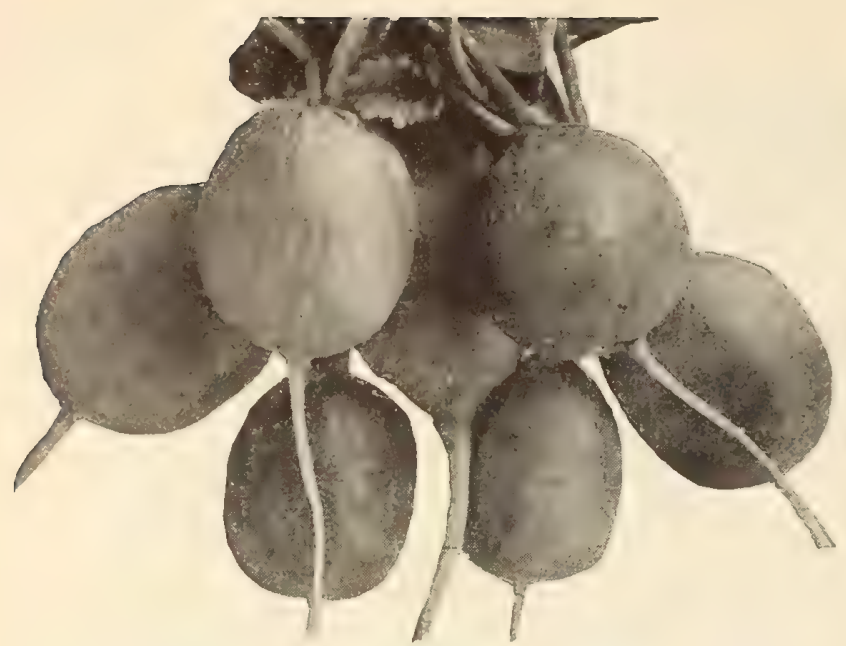

72. Bolgiano's No. 2 Scarlet Globe Radishes. Pkt. 5c.

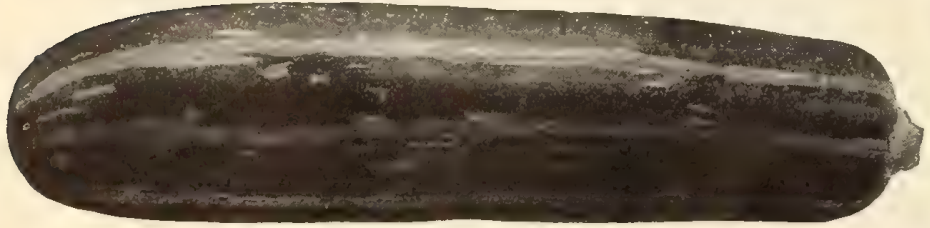

298. Cocozelle Squash. Pkt. 10c.

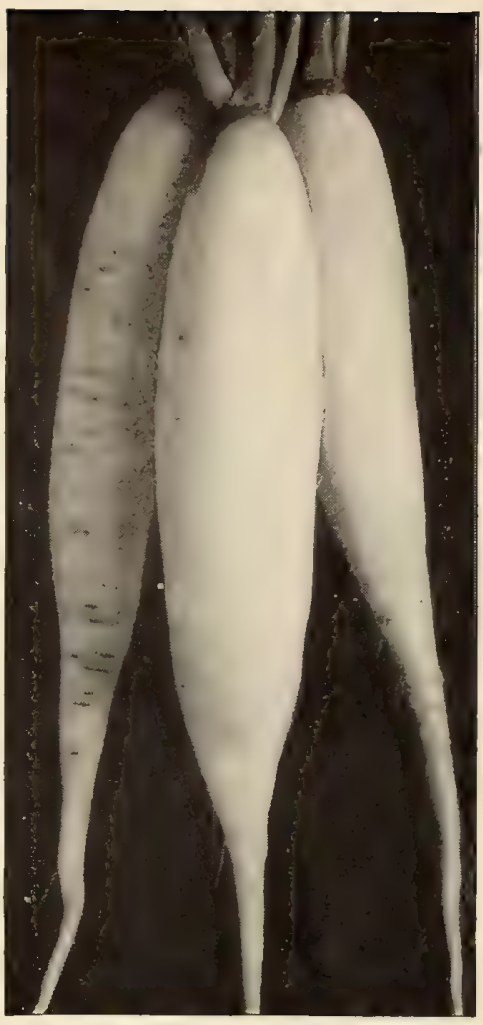

278. White Icicle Radishes. Pkt. 5c

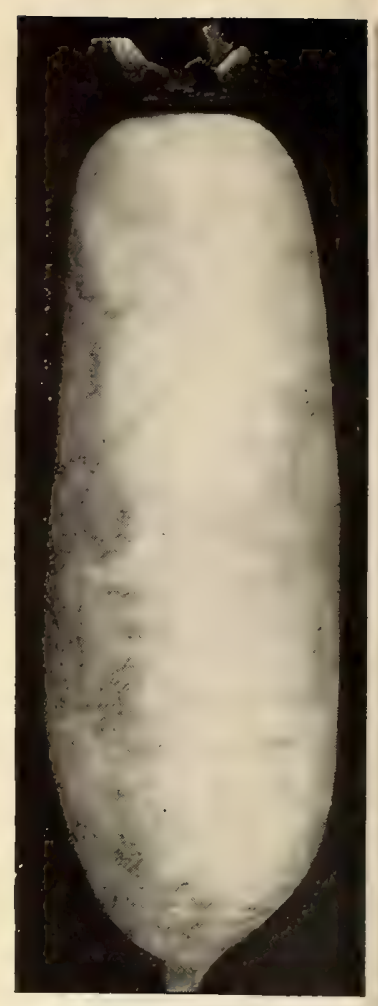

78. White Chinese Radish. Pkt. 10c.

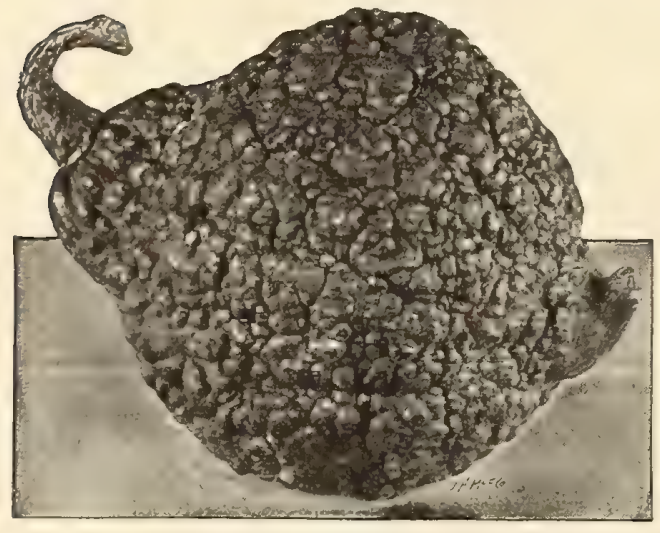

152. Hubbard Squash. Pkt. 10c.

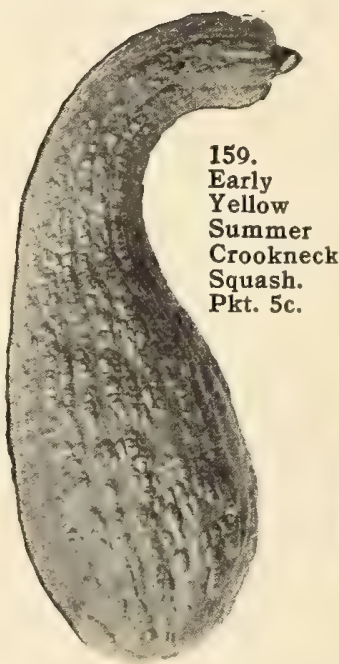

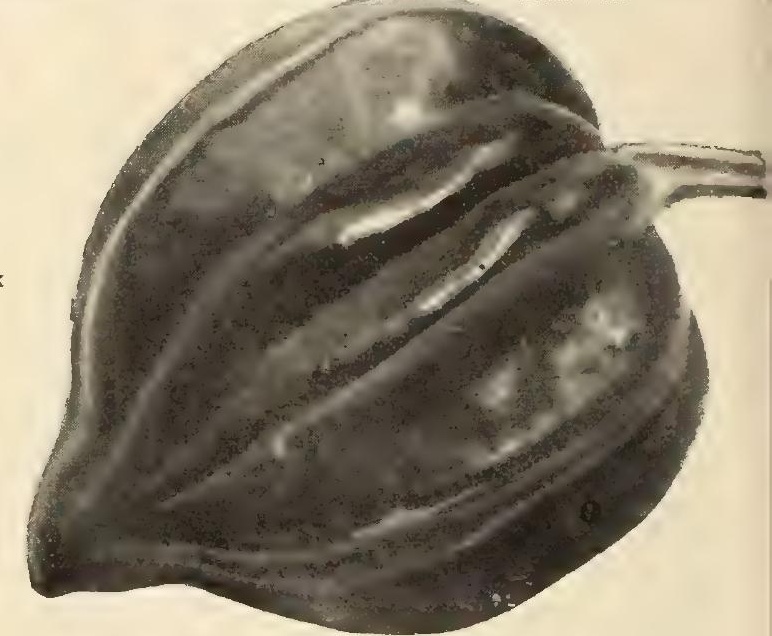

96. Acorn or Table Queen Squash. Pkt. 10c.

कित-

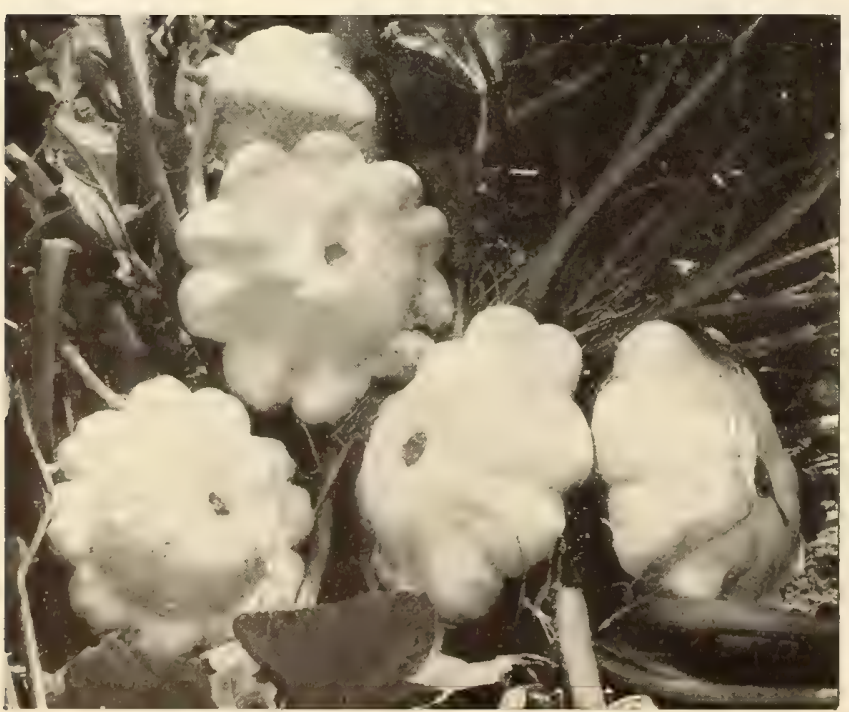

82. Farr's Benning White Bush Squash. Pkt. 10c.
(1) $x^{2}+3=-1025$

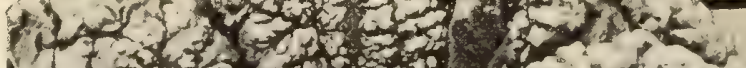

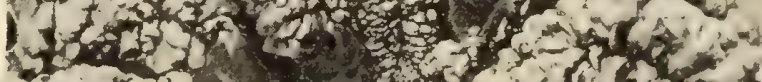

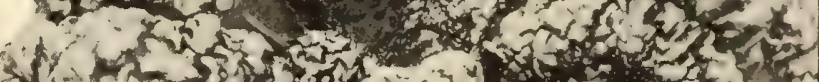

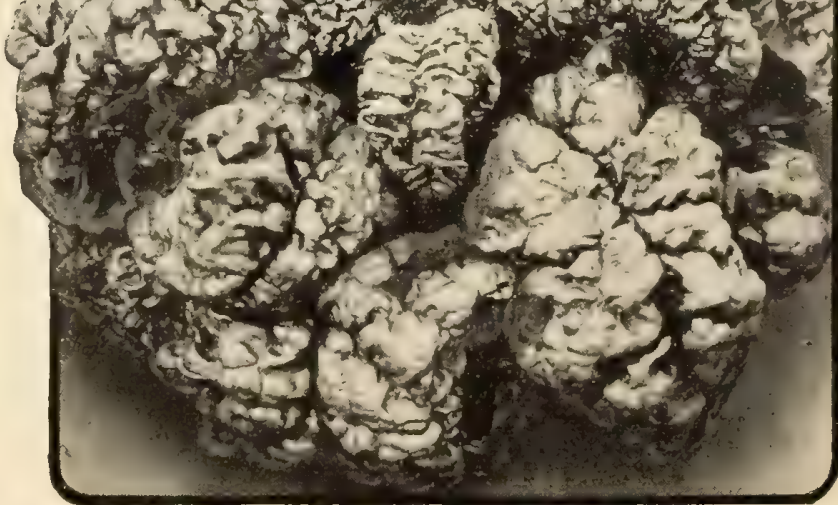

604. Long-Standing Bloomsdale Savoy Spinach. Pkt. 10c. 


\section{RHUBARB}

One ounce will produce 500 plants.

Prices include postage on pkts., ozs., $1 / 4 \mathrm{lbs}$., and $\mathrm{lbs}$.

Culture. Sow seed 1 inch deep in rows and thin to stand 6 inches apart. By fall they should be moved to their permanent location, in heavily manured ground, and spaced 3 to 4 feet apart. A heavy manure mulch around the crowns each winter will furnish extra-quality stalks.

203. Victoria. A vigorous variety with upstanding thick red stalks of excellent quality. Pkt. 10c.; oz. 25c.; 1/4Ib. 85c.; Ib. $\$ 2.75$, postpaid

Roots dozen, $\$ 1.00$; add 25c. per doz. if sent by mail. $\$ 7.50$ per 100 by Express collect.

\section{SALSIFY or OYSTER PLANT}

One ounce will sow 50 feet of row; 8 to 10 pounds, an acre.

Prices include postage on pkts., ozs., $1 / 4 \mathrm{lbs}$., and lbs.

Cuiture, Does best in a light, rich, mellow soil and requires about same treatment as parsnips; can be left in ground all winter. Sow 1 inch deep in rows early in spring. Thin to stand 6 inches apart.

Salsify is a delicious vegetable and really has an oyster flavor.

291. Bolgiano's Great Giant. (110 days.) With the largest, smoothest roots of any variety, it outyields and outsells them, thereby pleasing the truckers. Pkt. 10c.; oz. $25 \mathrm{c}$.; $1 / 4 \mathrm{Ib} .75 \mathrm{c}$; Ib. $\$ 2.25$, postpaid.

116. Sandwich Island Mammoth. (120 days.) Roots 8 to 9 inches long and $11 / 2$ to 2 inches in diameter. Flesh is almost white and the oyster flavor is excellent. Pkt. 10c.; oz. 20 c.; $1 / 4$ Ib. 65 c.; Ib. $\$ 2.00$, postpaid.

\section{SPINACH}

One ounce will sow 100 feet of row; 15 pounds, an acre.

Prices include postage on pkts., ozs., $1 / 4 \mathrm{lbs}$., and lbs.

Spinach is an excellent source of supply for vitamins $A$ and $C$ and furnishes iron. An important vegetable for everyone's diet.

Culture. Use well-manured ground, and sow in rows, covering 1 inch deep, later thinning to 5 inches apart. Sow every two weeks from early spring until hot weather. Sow again in September for a fall crop.

602. Bolgiano's Selected Bloomsdale Savoy. (39 days.) A furst-early, vigorous variety with fast-growing plants which are hardy and attractive. Leaves are dark glossy green and are heavily savoyed.

Pkt. 10c; oz. 15c。; 1/4lb. 30c.; Ib. 85c., postpaid

605. Extra Dark Green Savoy. (40 days.) Because of its darker color this special train retains a fresh appearance at market. Pkt. 10c; oz. 15c; $1 / 4 \mathrm{lb} .30 \mathrm{c}_{*} ;$ Ib. $85 \mathrm{c}$, postpaid

604. Long-standing Bloomsdale Savoy. (45 days.) "Best-in-Garden" variety. While not quite so early as the preceding varieties it remains in cutting condition long after earlier types have gone to seed. The highly crumpled and blistered dark green leaves are unusually attractive.

Pkt. 10c.; oz. 15c.; 1/4lb. 30c.; Ib. 85c., postpaid.

212. New Zealand (Tetragonia expansa). ( 55 days.) This is not a true Spinach but the thick dark green foliage can be picked repeatedly throughout the summer and fall. Cooked like Spinach, it is a splendid "greens" with a Spinach-like flavor. Seeds are hard and should be soaked for some time in warm water and planted in warm soil. Thrives in hot weather. Pkt. $10 \mathrm{c}$. oz. $25 c_{\text {c }} ; 1 / 4$ Ib. 60 c.; Ib. $\$ 2.00$, postpaid.
139. Tendergreen or Mustard Spinach. (45 days.) A cross between Mustard and Spinach with a delicious Spinach flavor, It can be grown most of the year, being quite hardy in winter and standing hot weather as well. Leaves are gathered and boiled for "greens" just Iike Turnips, Mustard, Spinach or Kale. Pkt.

00. Victoria or Spring. (48 days.) Distinguished by its flat rosettes of large, crumpled, thick, very dark green leaves. Can be planted up into early summer and be sure of a crop. Pkt. 10c.; oz. 15c.; $1 / 4 \mathrm{lb}$.

$30 \mathrm{c}$; $1 \mathrm{~b} .85 \mathrm{c}_{\text {, }}$ postpaid.

ight-resistant Savoy. (40 days.) Bred at the Virginia Experiment Station for mosaic resistance, this variety is valuable for growing on infested soil The savoyed and crumpled leaves are crisp and tender. Growth is upright. Pkt. 10c.; oz. 15c.; 1/4 Ib. 30c.; Ib. 85c., postpaid.

\section{SQUASH}

SUMMER SQUASH. One ounce will plant 25 hills; 3 to 4 pounds, an acre.

WINTER SQUASH. One ounce will plant 15 hills; 3 pounds, an acre.

Prices include postage on pkts., ozs., $1 / 4 \mathrm{lbs}$., and lbs.

Winter Squash are an excellent source of Vitamin A, while Summer Squash provide both $\mathrm{A}$ and $\mathrm{C}$.

Culture. Plant in hills like cucumbers and melons, the bush varieties 3 to 4 feet apart and the running kinds 6 to 9 feet.

\section{Summer Varieties}

298. Cocozelle or Italian Vegetable Marrow. (65 days.) Large, oblong, dark green fruits becoming marbled with yellow when mature. Fine-grained flesh of excellent Iavor $\mathrm{Pkt} 10 \mathrm{c}$; $15 \mathrm{c} ; 1 / \mathrm{Ib}, 35 \mathrm{c}$ Ib. $\$ 1.00$, postpaid.

111. Early White Bush Scallop or Patty Pan. (52 days.) This old favorite for home and market gardens is shaped somewhat like a pie with scalloped edges. Pkt. $5 c$

Oz. $15 \mathrm{c}$; $1 / 4$ Ib. $35 \mathrm{c}$; I Ib. $\$ 1.00$, postpaid.
159. Early Yellow Summer Crookneck. (52 days.) The earliest Crookneck. Warted yellow skin. Flesh of splendid quality. postpaid.

82. Farr's Benning White Bush. (50 days.) "Best-in-Garden" variety. It is with great satisfaction that we can continue to offer this unrivaled Squash. For the past twenty-frve years this stock has furnished the earliest Squash to come on our market. In productiveness also it excels other varieties, being an exceptionally heavy cropper. The color is a
beautiful green tinted white possessed by beautiful green tinted white possessed by
no other variety. The flavor is delicious, has a few small seeds and is an excellent cooker. The strain which we offer is that originated by Mr. N. E. Farr and has been grown under our own supervision so as to constantly maintain and improve the quality. Pkt. 10c.; oz. 15c.; 1/4 Ib. $35 \mathrm{c}$. lb. $\$ 1.00$, postpaid.

331. Giant Summer Straightneck. $(60$ days.) A selection from Crookneck with straight, heavily warted fruits. Pkt. $10 \mathrm{c}$.; oz. 15 c.; $1 / 4$ Ib. 35 c.; Ib. $\$ 1.00$, postpaid.

\section{Winter Varieties}

96. Acorn or Table Queen. (60 days.) In size the Acorn Squash equals a fair sized husked cocoanut, and a half, when baked, serves one person amply. The shell is unusually thin and does not require over twenty minutes for baking or boiling. It retains its dark green color after picking and storing. The meat is dry and mealy. It yields enormously-a few hills furnishing an ample supply for a good-sized family. Pkt. 10c.; oz. 15c.; 1/4lb. 40c.; lb. $\$ 1.25$, postpaid.
140. Golden Hubbard. (100 days.) A smaller and somewhat earlier Hubbard, popular with home and market gardeners and canners. Fruils weigh 6 to 10 pounds, of fine quality. Pkt. 10c.; oz. 15c.; 1/4l $50 \mathrm{c}$; Ib. $\$ 1.50$, postpaid.

152. Hubbard.

Winter Squash for years. warted exterior and fine-grained, orangeyellow flesh which is dry, sweet and richly Havored. It bakes very dry. Our stock of $15 \mathrm{c}$-; $1 / 4 \mathrm{Ib}$. $50 \mathrm{c}$; ; Ib. $\$ 1.50$, postpaid.

237. Warted Hubbard. (110 days.) A larger Hubbard more thickly covered with warts. The same high-quality Hubbard
flesh. Pkt. 10c.; oz. 15c.; 1/4 Ib. 50c.; Ib. $\$ 1.50$, postpaid.

\section{TOBACCO}

Culture. One ounce of Tobacco produces at least 10,000 plants if sown properly. It is advisable to sow as early as possible, the the place intended for the seed-bed, in order to destroy weed seeds. The ground is put in the funest possible condition, the seed sown broadcast on the surface and pressed down firmly with a plank or the back of a spade, after which the bed must be protected by cotton or covering. When seedlings get 5 to 4 feet apart, with 3 .

255. Connecticut Seed-Leaf. Hardy, proitic variety

Pkt 10 c.

Pkt. 10c.; oz. 35c.; 1/4lb. \$1.15, postpaid 292. Maryland Broad-Leaf. Bears thick, broad leaves which produce a high pe Pkt. 10c.; oz. 35c.; 1/4lb. $\$ 1.15$, postpaid.

\section{TOMATO}

One ounce will produce 1500 plants 6 ounces will plant an acre.

Prices include postage on pkts., ozs., $1 / 4 \mathrm{lbs}$., and $1 \mathrm{bs}$.

Tomatoes are reliable providers of vitamins $A$ and $C$ and every garden requires a lot of them to

Curture. Seed should be started in hotbed in March, transplanted to a coldframe, and finally to open ground in May. The soi should be rich and in full sun but protected from wind. In the home-garden the pl

should be supported on stakes or wires.

\section{Red Varieties}

79. Bolgiano's Greater Baltimore. days.) A universal canning favorite Iarge plants produce unusually heavy tonnage per acre. Fruits are medium large, deep carlet, furm and meaty. Pkt. 10c.; oz. 30c.;

24. Bolgiano's Red Beefsteak. days.) A Iarge Tomato for home and market use. Plants are heavy and of open habit. The scarlet-red, solid fruits have deep scarlet flesh with a rich subacid flavor. A meaty Tomato growing rapidly in popularity. Pkt. 25c.; oz. 65c.; 1/4 Ib. \$1.50; lb. $\$ 5.00$, postpaid.

155. Bonny Best. (100 days.) A standard variety for market gardeners, shippers and canners. Plants of average size produce bright scarlet, smooth fruits of me-
dium size and excellent quality. Pkt. $10 \mathrm{c}$. oz. 30c.; $1 / 4 \mathrm{Ib} .90 \mathrm{c}$; lb. $\$ 3.00$, postpaid.

101. Break o'Day. (95 days.) A wilt-r

sistant variety introduced by the U. $\mathrm{S}$.
Department of Agriculture. The spreading plants bear early and prolifically. Fruits are medium sized, smooth globes of orangered and have a deliciously sweet flavor.

Pkt. 10c.; oz. 35c.; 1/4lb. \$1.00; lb. $\$ 3.50$, postpaid. 
TOMATO, RED VARIETIES, continued

138. Earliana Improved. ( 90 days.) This is Bolgiano's special strain and produces heavier crops of smoother fruit than the old type. Fruits are medium size, flattened, firm, bright rad. Always reaches market when a crop means real money.

Pkt. 10c.; 0z. 35c.; 1/4lb. \$1.00; Ib. \$3.50, pcistpaid.

Bolgiano's Extremely Early. (90 days.) The largest, most prolific early Tomato- Pkt. 10c.; oz. 35c.; 1/4lb. \$1.00 Ib. $\$ 3.50$, postpaid.

88. Marglobe. Reselected and improved from originator's strain. ( 100 days.) "Best-in-Garden" variety. A second-early "Best-in-Garden" variety. A second-early plants which continue to thrive and bear fine fruit long after other varieties are gone. Fruits are beautiful red globes with meaty flesh of delicious flavor, free from acid. A good shipper and should be in every hone-garden. Pkt. 10c.; oz. 35c.; 1 I Ib. \$1.00; lb. \$3.25, postpaid.

332. Pritchzrd or Scarlet Topper. (95 days.) "Best-in-Garden" variety. Another U. S. Department of Agriculture introduction with self-topping plants resistant to fusarium wilt and nail-head rust. Globular, thick-walled, light scarlet fruits. Pleases both home and market gardeners and long-distance shippers. Pkt. 10c.; oz. 35c.; I IIb. \$1.00; Ib. \$3.25, postpaid.

330. Red Cherry. (115 days.) Delightful little cherry-like, scarlet-red fruits valuable for preserving.

Pkt. 10c.; oz. 50c.; 1/115. \$1.50, postpaid.

135. Rutgers. (100 days.) Fruits are medium to large, globe-shaped, slightly flattened at the stem end. Flesh very frrm and red. This variety ripens from the insile, or gets its color on the inside before it fully ripens up on the outside, which makes it especially desirable for canning and for juice. The vines are vigo:ous, quite leafy and more resistant than some other sorts to blight and other Tomato diseases. Pkt. 10c; ; oz. 35c.; 1/4lb. \$1.00; Ib. $\$ 3.25$, postpaid.

307. Scarlet Dawn. (90 days.) An extraearly Tomato successful for garden, shipping, and canning. Plants are of average size and are good producers. Medium-sized fruits of bright scarlet ripen well to the stem. Pkt. 10c.; oz. 35c.; $1 / 4$ Ib. $\$ 1.00$; lb. $\$ 3.50$, postpaid.

61. Stone. (115 days.) Always makes good for a main crop of large, solid, scarlet-red fruits which keep well and do not crack. Pkt. 10c.; oz 25c.; 1/4lb. 75c.; lb. $\$ 2.50$, postpaid.

86. The Bolgiano or Potato-leaf Tomato. (90 days.) Blossoms continually. Every vine is just loaded with perfect red solid Tomatoes all during the season. The Bolgiano Tomato is two weeks earlier than Marglobe. First fruit just as perfect as the prime fruit of the season. Its heavy potato-leaf foliage protects the fruit from sun-scalds and blisters. Pkt. 10c.; oz. 40c.; $1 / 4 \mathrm{lb} . \$ 1.25 ; 1 \mathrm{~b} . \$ 4.00$, postpaid.

249. The Washington. (100 days.) Heavyyielding, wilt-resistant plants for a main cropper. Fruits are perfectly smooth, solid, rich red and meaty. Pkt. 10c.; oz. $25 \mathrm{c}$; $1 / 4$ Ib. 85 c.; Ib. $\$ 3.00$, postpaid.

\section{Pink Varieties}

227. Oxheart. (118 days.) Great rosy pink, heart-shaped fruits up to 2 pounds each. They are very solid with few seeds and are mildly acid. Pkt. $10 \mathrm{c}$; oz. $75 \mathrm{c}$.; $1 / 4$ lb. $\$ 2.00$; Ib. $\$ 7.00$, postpaid

348. Livingston's Beauty. $(100$ days. Large, deep, flat, smooth fruits of purplish pink. Pkt. 10c.; 0z. 25c.; 1/4 Ib. 85c. b. $\$ 3.00$, postpaid

46. Ponderosa. (115 days.) This largest of all Tomatoes. Has few seeds and its flesh is sweet and mild. Quite often called the "Beefsteak" Tomato. Pkt. 10c.; oz. 65c.; $1 / 4$ Ib. $\$ 1.75$; Ib. $\$ 6.00$, postpaid.

\section{Yellow Varieties}

276. Golden Queen. (110 days.) Large golden yellow fruits of mild flavor; smooth and solid.

Pkt. 10c.; oz. 50c.; 1/4 Ib. $\$ 1.50$, postpaid.

242. Mingold. (105 days.) An early and prolific yellow Tomato of mild and pleasant

Pkt. 10c.; oz. 50c.; 1/1b. \$1.50, postpaid. 323. Pear-shaped. (100 days.) A brigh preserves.

Pkt. 10c.; oz. 50c.; $1 / 4 \mathrm{~Kb}$. \$1.50, postpaid.

196. Plum-shaped. (100 days.) Oval, plum-shaped, yellow fruits. A preserve

Pkt. 10c.; oz. 50c.; 1/4lb. \$1.50, postpaid.

\section{TURNIPS}

One ounce will sow 100 feet of row; 2 pounds, an acre.

Prices include postage on pkts., ozs., $1 / 4$ lbs., and lbs.

Turnip roots provide vitamin $C$ but Turnip tops not only rate excellent as suppliers of tities of calcium and iron. Never discard are palatable and highly nutritious.

Culture. They do best in highly enriched, light, sandy or gravelly soils. Commence sowing the earliest varieties in Apri in drills from 12 to 15 inches apart, and thin out early to 6 to 9 inches in rows. For a succession sow at intervals of a fortnight urtil the last week in July; from then until the end of August sowing may be made for the fall and main crop. Turnips may be preserved until spring by cutting off the tops about 1 inch from the bulb, storing in the cellar or cold shed during the winter, coverirg the vested before the severe frost sets in, for, though comparatively hardy, few will survive the winters of the Northern States in the open ground.

119. Amber Globe. (75 days.) A yellowfleshed variety; fine-grained, tender and sweet; top bronzy green. Roots most desirable for table use when 3 to 4 inche in diameter. 75 c., postpaid.

50. Early Red or Purp' - -Top Strap-Leaf. (46 days.) A medium-early Turnip. Flat roots, purple-red above, white below. Medium small tops. Flesh white and fine grained. Pkt. 5

84. Extra-Early Milan Purple-Top days.) Very small tops with small flat white roots with purplish tops. Flesh white, sweet and tender. Pkt. 10c.

179. Extra-Early White Milan. ( $40 \mathrm{~d}$ An extremely early Turnip valuable for forcing. The very flat white roots are sweet and tender. Pkt. $10 \mathrm{c}$

177. Golden Ball or Orange Jelly. days.) An attractive Turnip with small erect tops and medium-sized round vellow roots with yeilow flesh of unusually fine texture and flavor. Pkt. $10 \mathrm{c}$

232. Pomeranian Globe or White GlobeNorfolk. (75 days.) A Southern favorite. Large tops with globular white roots. A heavy cropper. Pkt. 5c.; oz. 10c.; $1 / 4 \mathrm{lb}$ 20c.; Ib. 65c., postpaid.

110. Purple-Top White Globe. (55 days.) "Best-in-Garden" variety. The most popular Turnip for home and market smooth globes, purple-red above, white below. The white flesh is sweet, crisp and tender. Pkt. 5c; oz. 10c.; 1/4 Ib. 20c.; lb. $65 \mathrm{c} .$, postpaid
176. Seven-Top.

greens" and forage. Tops are tender but

roots are unsuitable for food. Pkt.

171. Shogoin. ( 42 days.) Grown in the South where the tops are used for earl "greens." The small globular white root are very tender. Pkt. 10c.; oz. 15c.;

2. White

Eg. (55 days) Medium-sized tops with egg-shaped white roots of frine quality. Pkt. $65 \mathrm{c}$., post paid.

\section{RUTABAGA Swede Turnip}

136. Golden Neckless. (85 days.) splendid winter Turnip with large globula yellow roots. The yellow flesh is finegraine 1 and sweet. Pkt. $10 \mathrm{c}$; 148. Long island Special.

arge roots have very sweet golden flesh which is neither stringy nor tough. A splendid winter Turnip which keeps solid and 60c.; Ib. $\$ 1.75$, postpaid.

\section{HERBS}

Every year more house o old-time Herbs for flavor in preparin simple remedies for the medicine closet. O ancestors depended greatly on their garden
Herbs for their well-being ard in thes difficult times when so many of the things we had come to take for granted are now unobtamable, or hard to get, it is a good time for everyone with a garden to plant these
useful Herbs and get busy looking up Annuals are marked (A); Perennials (P) and Biennials (B)

286. Anise. (A) Leaves used for garnishing Anise. (A) Ieaver flavoring bread, cake etc. Sow where plants are to grow. 14 in 254. Besil, Sweet.

Crop failed.

failed.

265. Catnip.

284. Chives.

$25 c$. postpaid.

262. Dill

used to flavor pick

25. Fennel, Florence.

$10 \mathrm{c} .0 \mathrm{z}, 30 \mathrm{c}$. postpaid.

294. Fennel, Sweet.

soups, stews, etc. Seeds are used to flavo postpaid.

279. Lavender.

tems provide a perfume loved by

280. Sage. (P) Leaves furnish flavoring and seasoning especially for poultry and

268. Summer Savory.

salads and various

258. Sweet Marjoram.

and leaves are used for flav

also dried for winter

267. Thyme.

drietime home remedres. paid. 


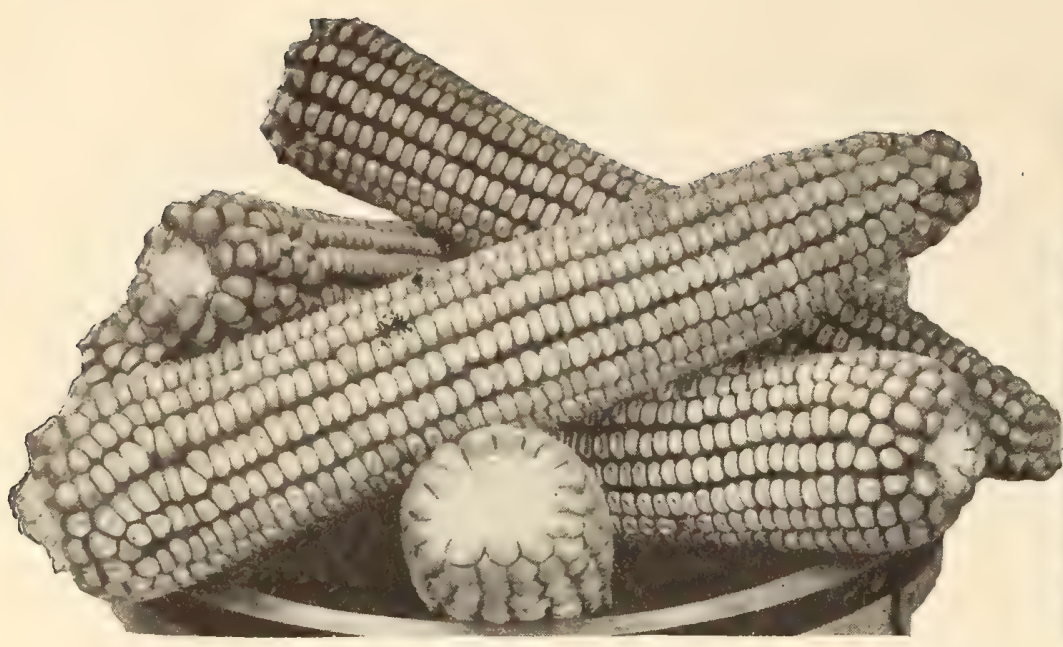

Yellow Dent Hybrid U. S. 13

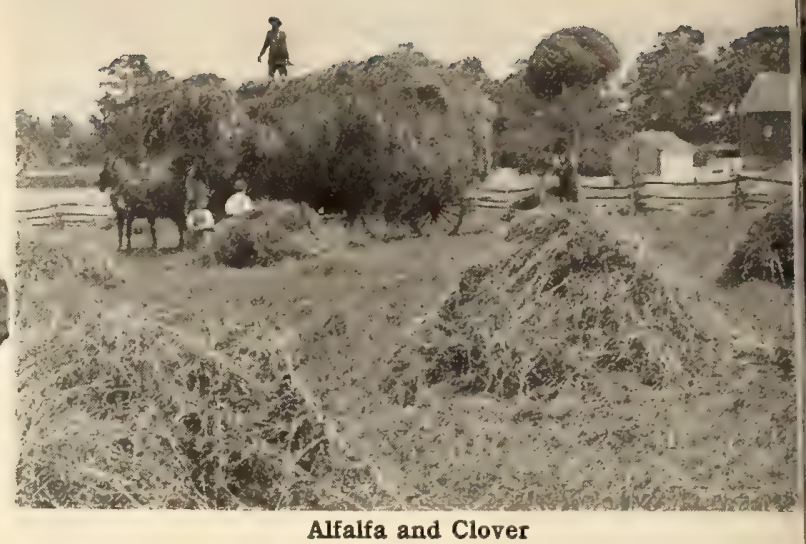

Alfalfa and Clover

\section{BolgiAnO's "Capitol Brand" Clover, Grass and Forage Seed — FOR PRICES, SEE PINK SHEET ENCLOSED - THE CLOVERS}

Alfalfa (Medicago sativa). Sow 20 to 25 pounds to the acre in thoroughly prepared soil either in spring or fall.

Alsike or Hybrid Clover (Trifolium bybridum). The hardiest of Clovers, resisting extremes of both heat and cold as well as drought. Sow 8 pounds to the acre

Crimson or Scarlet Clover (Trifolium incarnatum). Improves poor Iand and furnishes an abundance of forage at seasons when pastures are resting. May be planted in spring, summer or fall. Sow 15 pounds to the acre.

Mammoth or Sapling (Trifolium pratense perenne). A stronger grower than Red Clover and matures later. Recommended for thin soils. Sow 10 to 12 pounds per acre.

Medium Red or June Clover (Trifolium pratense). Makes two crops of hay each year and may be sown in either spring or fall. Sow 12 to 15 pounds per acre.

White Dutch Clover (Trifolium repens). Usually included in lawn grass mixtures, it is also valuable in permanent pastures. Sow in spring, using 1 to 2 pounds in mixture to the acre and 8 to 12 pounds when alone.

Inoculate all Legume Seed (Alfalfa, Clovers and Lespede
White Sweet Clover (Melilotus alba). Grows 3 to 5 feet tall and is valuable for soiling, ensilage and bees. Lasts for years if cut before flowering and on rich soil will produce three crops a year. Sow 15 to 25 pounds to the acre.

\section{Korean Lespedeza}

The most popular of the Lespedeza family, growing about $11 / 2$ feet tall and producing 2 to 3 tons of splendid hay equal to Alfalfa in feed value per acre. Grows readily in acid soil and reseeds itself, lasting several years. It is drought-resistant, is ready to cut in August and cures quickly. Sow 20 to 25 pounds per acre from February 1 to the last of May.

\section{Sericea Lespedeza}

This is a perennial which thrives on poor soil, withstands droughts and furnishes two or more cuttings per season after the first year Cut when about a foot high to make tender hay. Sow 30 to 35 pounds of unhulled seed per acre during February or 20 pounds of hulled seed from March 1 through June.

\section{THE GRASSES and FORAGE SEED}

Bermuda Grass (Cynodon dactylon)

A creeping perennial grass that succeeds on all soils; withstands drought and scorching summer sun better than any other grass. Covers bare spaces by long, overground runners; dies down completely in winter. Sow 5 pounds per 1000 square feet of lawn; 10 pounds per acre of pasture.

Chewing's Fescue (Festuca rubra commutata)

A creeping Fescue popular for lawns, golf-courses and pastures and thriving in shade it is used in most shady lawn mixtures. If used alone sow 8 pounds per 1000 square feet of lawn or 30 pounds per acre for pasture.

Creeping Bent Grass (Agrostis palustris)

Provides a durable turf for lawns and golf greens, standing close cutting. Sow 5 pounds per 1000 square feet of lawn.

\section{Domestic Rye Grass}

An all-purpose grass, used in lawn mixtures and for hay or pasture. Sow 10 pounds per 1000 square feet of lawn or 30 pounds per acre for hay or pasture.

Kentucky Blue Grass (Poa pratensis)

Although it does well on most any good soil, Blue Grass requires about two years to become established and is therefore often sown with other grasses. Sow in spring or fall. For lawns use 5 younds per 1000 square feet and 40 pounds per acre for pasture.

\section{Meadow Fescue (Festuca ovina)}

A deep-rooted perennial grass valuable for hay or pasture. Appears early in spring and lasts until late fall. Sow 25 pounds per acre

Orchard Grass (Dactylis glomerata)

An early bunch grass which stays green in spite of heat and drought. Lasts for years. Sow 28 pounds per acre.

Perennial Rye Grass (Lolium perenne)

A splendid permanent pasture grass doing best on moderately moist ground. Sow 30 to 40 pounds per acre in spring.

\section{Red Top or Herd's Grass (Agrostis palustris)}

Used in most lawn mixtures and a good pasture grass. Does well in low, wet meadows. Sow in spring or fall, using 5 pounds per 1000 square feet of lawn or 12 pounds per acre for pasture or hay.

\section{Timothy (Phleum pratense)}

This important hay and pasture grass should be sown at the rate of 12 pounds per acre in spring or fall. One popular mixture uses 10 pounds Timothy and 6 pounds Clover; another has 8 pounds Timothy, 6 pounds Clover (AIsike or Mammoth), 6 pounds Red Top and $1 / 2$ bushel Meadow Fescue to the acre.

\section{Bolgiano's Permanent Pasture Mixture}

These mixtures are composed of only the best germinating seeds and are sure to give satisfaction.

For Uplands: A special mixture of the best grasses and clovers for establishing a permanent pasture.

For Lowlands: A mixture of grasses and clovers adapted for moist or slightly sour lowlands.

\section{Dwarf Essex Rape}

An annual resembling kale which furnishes good pasture for poultry and livestock within six weeks after sowing. Sow 6 to 8 pounds broadcast per acre.

\section{Golden Millet}

Makes an enormous yield of hay which should be cut just as the heads begin to form. Sow from May through July at the rate of 30 pounds per acre.

\section{Hairy Vetch (Vicia villosa)}

Valuable as a winter cover crop to prevent leaching and to turn in for fertilizer. It is also a good forage plant. Sow 50 to 60 pounds per acre.

Sudan Grass (Holcus sudanensis)

Similar to Timothy in good value this provides an easily cured hay forage crop. Must be cut before frost. Sow 20 to 25 pounds per acre in late spring. Often sown with Soy Beans-20 pounds Sudan Grass and one bushel Soy Beans to the acre. 


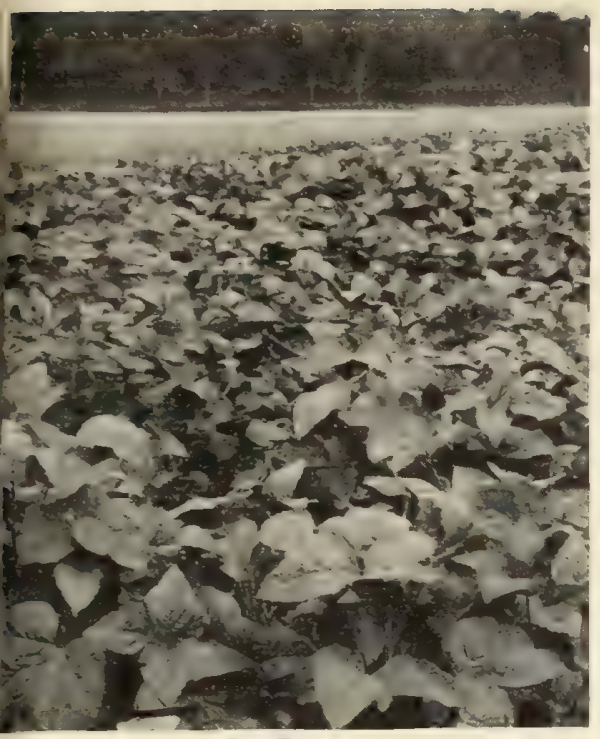

Soy Beans
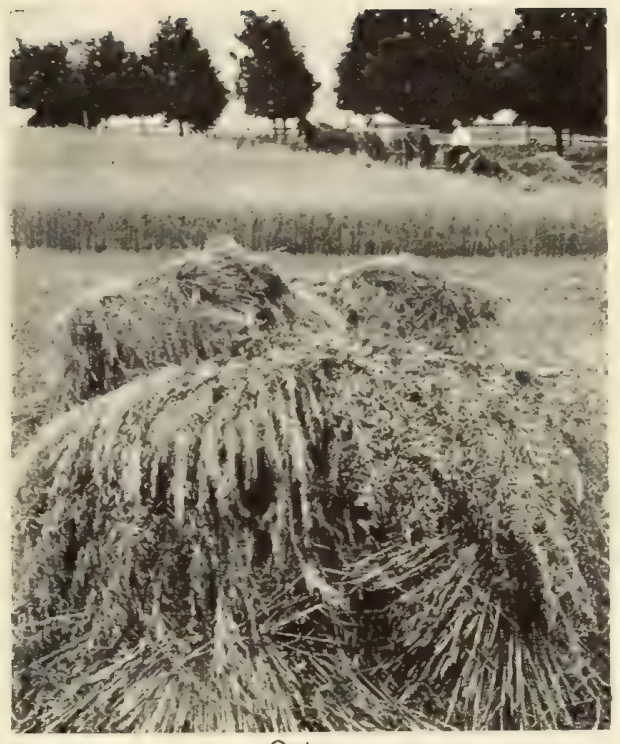

Oats

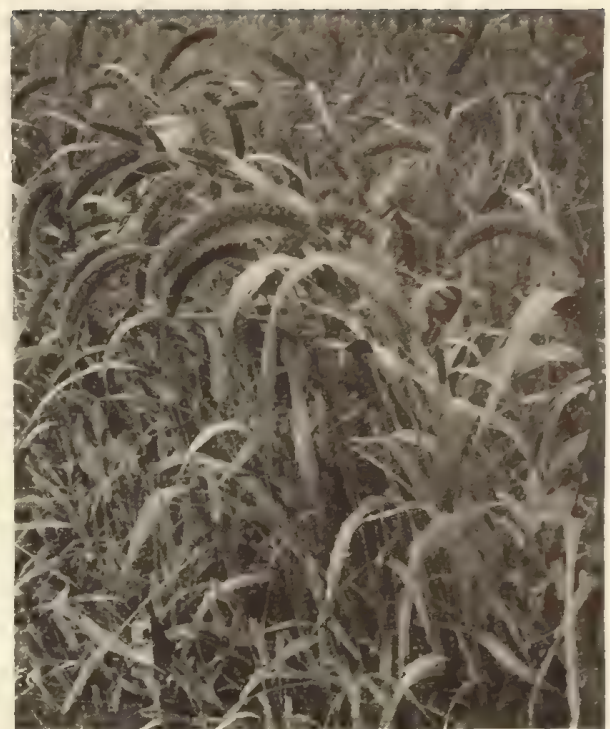

Golden Millet

\section{BOLGIANO'S "Capitol Brand" FIELD CORN}

Our Corn is grown especially for us in the best producing sections. Only good ears from healthy plants are taken and they are hand shelled and graded. For prices see pink sheet enclosed.

Bolgiano's Prosperity. (110 days.) Luxuriant plants 12 to 15 feet tall bear beautiful ears 10 to 12 inches long with 20 to 24 uniform rows of large, long kernels well developed over both tip and butt.

Boone County. (110 days.) A pure white Corn on a white cob. There are generally 20 or more rows of deep kernels on the heavy 10 to 11 -inch ears. Boone County is a heavy yielder of extraquality Corn.

Eureka Ensilage. (115 days.) Many years of watching and selecting seed has developed this best of all silo Corn until the rapid-growing plants now reach a height of 15 feet with a large amount of fodder and 3 or 4 long ears to the stalk.

Inoculate all Beans and Peas with Nitragin and insure a good crop. See page 70
Hickory King. (115 days.) Grows over 8 feet tall, with a splendid root-growth. Ears contain 8 rows of large broad kernels; small cob. A great white Corn especially recommended on poor soil. Popular for "roasting ears" and early feed in the South.

Improved Leaming. (112 days.) A rough Dent yellow Corn with ears 9 inches long, having 16 to 18 rows of deep kernels, and small red cob. Successful on any kind of soil.

Lancaster Sure Crop. (113 days.) An always reliable early Corn with long ears of reddish yellow.

Reid's Yellow Dent. (100 days.) The 10 -inch yellow ears have small red cobs covered with 18 to 20 rows of deep grains. Grows better than 8 feet tall. A consistent prize-winner at shows.

Yellow Dent Hybrid U. 5. 13. (110 days.) This Virginia-grown Corn is, we believe, the best Yellow Hybrid in the middle Atlantic section. Large show-type ears, 11 inches long, with 16 rows of deep kernels. Deep-rooting plants.

\section{"Capitol Brand" SOY BEANS, COWPEAS, and SMALL GRAINS

\section{SOY BEANS} \\ WHITE KAFFIR CORN}

A valuable Bean which can be grown for the Beans or used for hay, silage or green manure. Sow from May to July, 60 to 90 pounds per acre broadcast, or 45 to 60 pounds in drills.

Mammoth Yellow. (145 days.) The largest-growing variety for Virginia Brown. (125 days.) Vines stand about 3 feet high and Wilson Early Black. (120 days.) A small-seeded variety popular in the mountains and the North.

\section{BLACK-EYED PEAS}

Erect vines yielding large quantities of edible Peas.

\section{CANADA FIELD PEAS}

Second only to clover in their soil-enriching properties and can be grown about anywhere. The vines make nutritious hay and the ground Peas are valuable stock-feed.

\section{COWPEAS}

An inexpensive soil-improver yielding heavy crops of nutritious stock-feed. Sow 60 to 90 lbs. per acre broadcast or 45 to $60 \mathrm{lbs}$. in drills. Whippoorwill. (75 to 90 days.) An easy-to-harvest, uprightgrowing early variety.

Mixed Cowpeas. The upright growers hold up the vining types giving more satisfactory results.

\section{BARLEY}

Beardless Barley. Sow 72 to 96 pounds per acre.

\section{BUCKWHEAT}

Seed Buckwheat has the advantage of remaining for some trme in bloom and produces seed earlier. It resists drought and blight very well. Sow 1 bushel per acre.

ALL PRICES SUBJECT TO
A nutritious food for stock and poultry. Generally sown with cowpeas broadcast at the rate of 1 peck of Kaffir Corn to a bushel of Cowpeas per acre.

\section{OATS}

Sow 64 to 90 pounds per acre.

White Spring. Produces a bumper crop of hay or grain.

Winter or Turf. Sown in September or October it is excellent for winter grazing. Produces a large crop of heavy grain.

\section{RYE}

Sow 56 to 84 pounds per acre.

Abruzzi. Ready for grazing ten days earlier than other varieties, also produces more grain and straw.

Rosen. A Russian Rye used largely for turning under.

\section{SORGHUM}

Sorghum furnishes a Iarge yield of most nutritious forage, which can be fed either green or cured, and will yield 2 or 3 cuttings a year, stooling out thicker each time it is cut. It grows 10 to 12 feet high. Sow broadcast for forage at the rate of 1 to $13 / 4$ busheis to acre. When sowing in drills, sow at the rate of 1 peck per acre in drills $31 / 2$ to 4 feet apart.

\section{WHEAT}

Sow 75 to 120 pounds per acre.

Leap's Prolific. A tall beardless Wheat of heavy production.

\section{BROOM CORN}

Improved Evergreen. A tall variety yielding a long, heavy brush. Appearing green when ripe it commands highest market price Sow 5 pounds per acre in drills 3 feet apart and thin out to 3 inches. HANGE WITHOUT NOTICE 


\section{Antirrhinum (Snapdragon) A.}

One of the "easy-to-grow" flowers, blooming continuously during summer and fall. Plants are perennial in the South.

984. University of California Mixture. A mixture of Rust-resistant Snapdragons similar to the Majus grandiflorum type and eontaining a full range of colors. Perfected by the University of California after years of testing. The mixture contains all the most desirable colors and is almost totally rustproof, $21,2 \mathrm{ft}$. Pkt. 10c 1053. Rosalie. (Majus grandiflorum.) Bronze Medal, 1940 All-America Selections. Rust-resistant, basebranching plants produce 6 to 8 huge spikes of large, rich deep rose flowers with an underlying tone of amber.

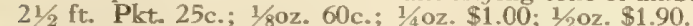
803. Tall Giant. (Maximum or Super Giants.) The tallest Rust-resistant Snapdragons producing long spikes for

cutting. A fine mixture of briliant colors. $23 / 4 \mathrm{ft}$. Pkt.

10c.; $1 / 8$ oz. 40c.; $1 / 4 \mathrm{oz}$. $75 \mathrm{c}$; $1 / 2 \mathrm{oz}$. $\$ 1.25$.

\section{LARGE-FLOWERED HALF-DWARF. R-G.}

(Rust-resistant)

Only 18 inches tall, this is a splendid type for bedding and spots in the rockery. Flowers are almost as Iarge as those of the grant types.

1010. Apple Blossom. Rose-pink with white tube. Pkt. $10 \mathrm{c} \cdot 1 / 30 \mathrm{O}, 50 \mathrm{c} \cdot 1 / \mathrm{OOz} 90 \mathrm{c} \cdot 1 / 2 \mathrm{Oz} \$ 1.50$

1056. Firebrand. Brilliant crimson. Pkt. 15c.; 1/80z $60 \mathrm{co} ; 1 / 4 \mathrm{oz} . \$ 1.00$.

1030. Purity. Fine white. Pkt. 20

805. Mixed. All colors. Pkt. 10c,; 1/40z. 75c.; 1/20z. \$1.25.

\section{Asters A.}

Asters provide the finest of long-stemmed cut-flowers during Iate summer and fall. They should be planted in a different location each year.

American Branching, Vick's Wilt-resistant Strain. Robust, branching plants, $21 / 2$ to 3 feet tall, bloom in early September. The large double flowers have fune form. Our Selected Stocks of them are the best 787. Azure-Blue.

785. Crimson.

788. Purple (Dark Blue)

784. Shell-Pink (Mary Semple)

783. White.

Any of above Asters, pkt. 10c.; 1/80z. 30c.; 1/40z. 50c.; oz. $\$ 1.60$

789. American Branching, Mixed. Pkt. $10 c_{*} ; 1 / 80 z_{.} 25 c_{.}$; $1 / 40 z$. 45c.; oz. $\$ 1.50$.

\section{CALIFORNIA GIANTS}

Large full flowers of the Crego type with broad petals beautifully curled and interlaced. The 3-foot plants bloom from Iate summer until frost with $1 \frac{1}{2}$ to 2 -foot stems. 1005. Deep Rose.

1003. Peach Blossom.

1006. White.

Any of above Asters, pkt. 10c.; 1/80z. 50c.; 1/40z. 85c.

793. Mixed. Pkt. 10c.; $1 / 8$ oz. $45 \mathrm{c} . ; 1 / 40 \mathrm{oz}_{0} 80 \mathrm{c}$.

791. California Sunshine. The 4 to 5 -inch flowers have a single row of long narrow petals which contrast with the unique yellow center disc of quill-like petals, each tipped with a four-pointed star. Mixed colors. Pkt. $10 \mathrm{c}$.; $1 / 8$ oz. 50c.; 1//0z. 90c. 1/20z. $\$ 1.60$.

980. El Monte. (Super-Giant.) The Super-Giants are the largest of Asters and EI Monte is a beautiful specimen. The daintily interlaced crimson petals form a fluffy bloom 6 inches or more across. Plants are $21 / 2$ feet tall and bloom very early. Pkt. 15c.; 1/80z. 50c.; 1/40z. 90c.; $1 / 2 \mathrm{oz}$. $\$ 1.60$.

794. Heart of France. (Wilt-resistant.) The reddest of all red Asters. Medrum-sized flowers of rich dark red. Blooms in Iate August on $11 / 2$ to 2 -foot plants. Pkt. $10 \mathrm{c}$; $11 / 8 \mathrm{oz}$. 50c.; $1 / 40 \mathrm{Oz}$. 90c.; $1 / 2$ oz. $\$ 1.60$.

\section{IMPROVED CREGO (Wilt-resistant)}

The Crego is an Aster of truly beautiful form and this Improved Wilt-resistant type is a great advance. Strong, branching $21 / 2$-foot plants are generous with their splendidly formed flowers in mid-September.

780. Azure-Blue.

781. Purple (Dark Blue)

779. Crimson. 777. White.

\section{Pink.}

Any of above Asters, pkt. 10c.; 1/80z. 25c.; 1/40z. 45c oz. $\$ 1.60$

782. Improved Crego, Mixed, Plkt, 10c.; 1/80z, 25c $1 / 4$ oz. 40c.; oz. $\$ 1.50$.

ALL PRICES ARE SUBJECT TO MARKET CHANGES

WASHINGTON, D. C. 29

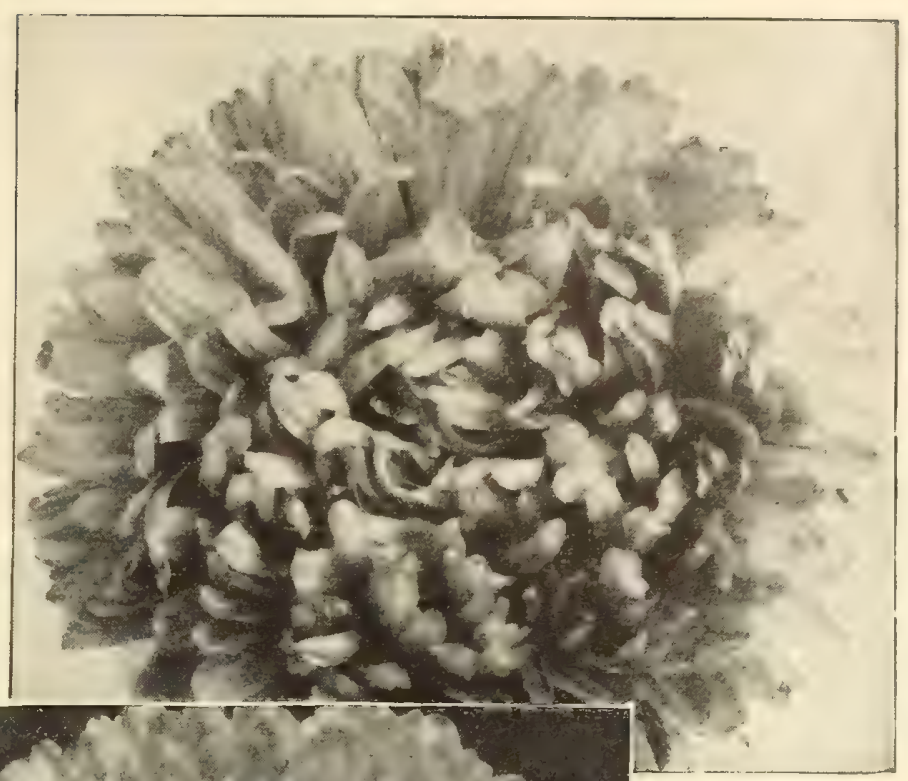

794. Aster, Heart of France
Pkt. 10c.

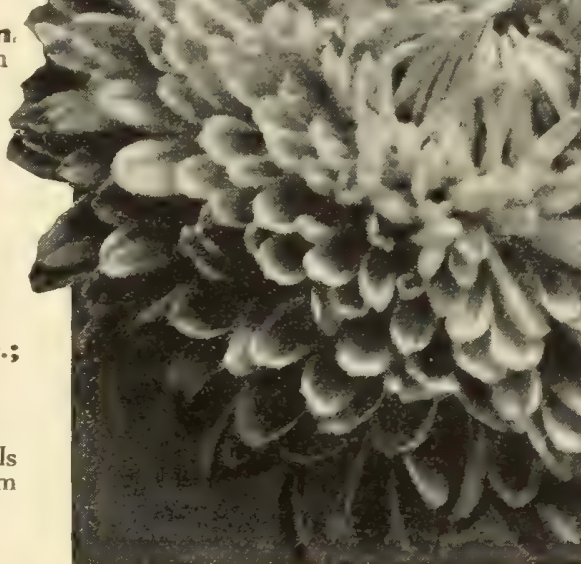

Aster, Wilt-Resistant Branching Pkt. 10c.

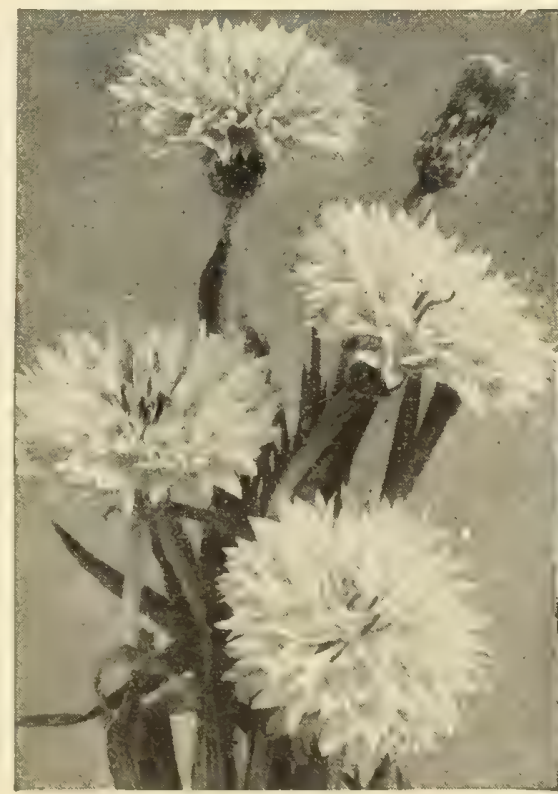

Centaurea Cyanus (Bachelor's Button) Pkt. 10c. Pkt. 10c.

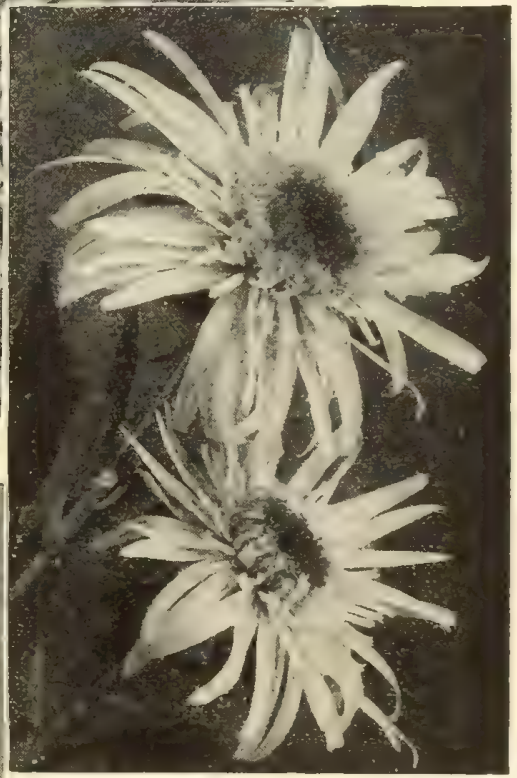

791. Aster, Giant California Sunshine

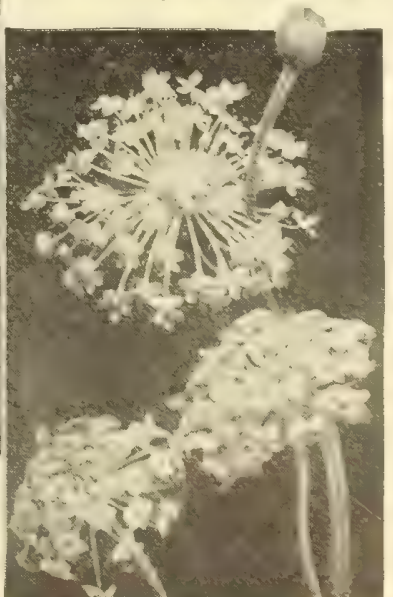
Plat. 10c. 


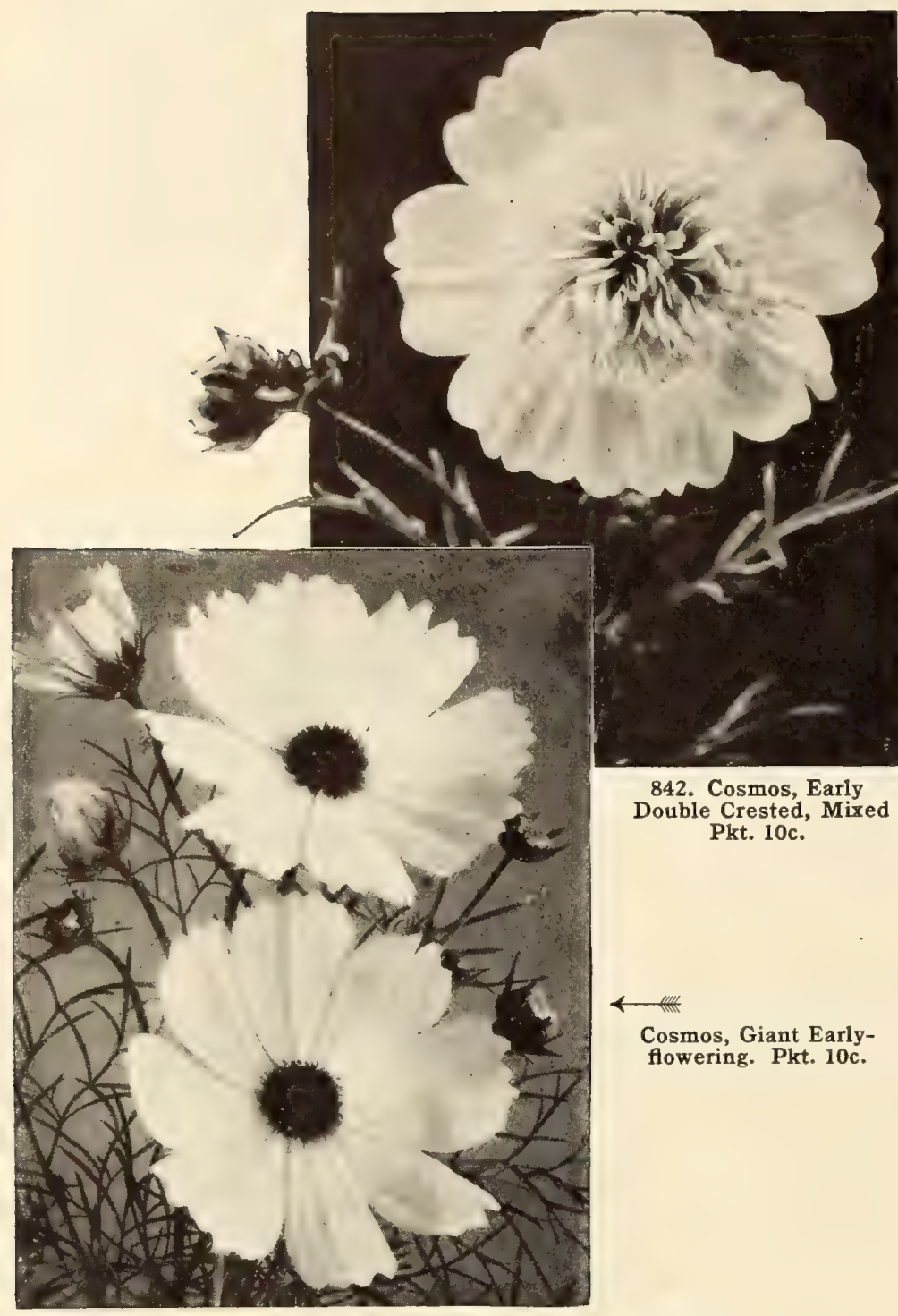

ASTERS, IMPROVED CREGO (Wilt-Resistant), continued

910. Los Angeles. (Super-Giant.) A Iovely companion to El Monte, and practically a twin except for color which is dainty shell-pink. Pkt. 15c.; 1/80z. 50c.; 1/40z. 90c.; $1 / 20 z \$ 160$

790. Queen of the Market. (Wilt-Resistant.) Branching plants about 20 inches tall, bloom in early August. Double flowers on long stems. Mixed colors. PLt. 10c.; $1 / 8$ oz. 30c.; $1 / 4$ oz. 50c.; oz. $\$ 1.25$.

\section{Balloon Vine}

808. Love-in-a-Puff. A. An attractive, rapid-growing annual climber with white flowers followed by inflated seed-pods. Pkt. 10c.; 1/4oz. 15c.; 1/2oz. 25c.; oz. 45c.

\section{Double Balsam (Lady-Slipper) A.}

An old favorite garden flower of easy culture. Bushy 2-foot plants bear masses of brilliantly colored flowers.

809. Camellia-flowered, Mixed. Crimson, pink, pale rose, lilac, lemon, and a host of other colors. Pkt. 10c.; 1/40z. 25c.; 1/20z. 45c; oz. 75c.

\section{Balsam Apple A.}

810. Momordica Balsamina. A curious climbing vine with glossy green foliage and golden yellow, appleshaped fruits. Pkt. 10c.; $1 / 40 z$. 20c.; 1/20z. 35c; oz. 60c.

\section{Blue Lace Flower}

932. Didiscus carulea. Upright, 2-foot, branching plants, each branch ending in an umbrella-shaped head of sky-blue flowers. A splendid cut-flower, blooming from midsummer to frost. Pkt. 10c.; 1/80z. 25c.; 1/40z. $40 \mathrm{c}$; ; 1/20z. 65c.

\section{Calendula (Pot-Marigold) A.}

Free-branching 2-foot plants that do best in a cool Iocation. A fine cut-flower.

826. Chrysantha. Large, double flowers of clear, buttercup-yellow with incurved petals. Closely resembles a chrysanthemum. Pkt. 10c.; 1/20z. 25c.; oz. 45c.

1011. Lemon Queen. Double flowers of Iemon-yellow. Pkt. 10c.; $1 / 2$ oz. 25c.; oz. $40 \mathrm{c}$.

811. Orange King. Rich orange-yellow; double. Pkt. 10c.; $1 / 2$ oz. 25c.; oz, $40 \mathrm{c}$.

812. Orange Shaggy. Interestingly different flowers of deep orange. The florets overlap each other in an irregular fashion so that the bloom looks like a shaggy chrysanthemum. Pkt. 10c.; $1 / 2$ oz. 25 c.; oz. $45 \mathrm{c}$.

987. Radio. A type with quilled petals forming a globular flower. Color is warm deep yellow. Pkt. 10c.; $1 / 20 z$.

813. Double, Mixed. A fine mixture of yellow and orange shades. Pkt. 10c.; 1/20z. 20c.; oz. 35c.

\section{Calliopsis A.}

An easy-growing annual with Iong-stemmed yellow flowers for cutting. $2 \mathrm{ft}$.

1031. Golden Crown. A semi-double flower of rich yellow with a maroon center. They are fragrant, too. Pkt.

814. Tall Single, Mixed. Lovely Daisies in shades of yellow. A desirable cut-flower. Pkt. 10c.; 1/40z. 15c.; $1 / 2$ oz. $25 \mathrm{c}$.; oz. $40 \mathrm{c}$.

\section{Candytuft (Iberis) A., P., R-G.}

Desirable and dependable annuals and perennials for the front of the border and rock-gardens. Easy to grow.

816. Giant Hyacinth-flowered. A. Plants to $11 / 2$ feet tall with enormous trusses of snow-white flowers. A popular florists' variety. Pkt. 10c.; $1 / 4 \mathrm{oz}$. 25c.; $1 / 2 \mathrm{oz}$. $45 \mathrm{c}$; oz. $85 \mathrm{c}$.

817. Dwarf Hybrids, Mixed. A. Large flowers of rose, salmon, coral, pink and lilac. Splendid bedding plants. Pkt. 10c.; 1//0z. 15c.; 1/20z. 25c.; oz. 40c.

818. Gibraltarica. P. Lovely little evergreen bushes hardly a foot tall with lilac flowers shading to white. A fine rock-garden ornament. Pkt. 10c.; $1 / 40 \mathrm{oz}$. 40c.; $1 / 2 \mathrm{oz}$. $75 \mathrm{c}$; ; oz. $\$ 1.25$.

\section{Canna A.}

820. Mixed Colors. Everyone has a place for these luxuriant plants with their enormous, brilliant clusters of bloom and broad leaves of green or bronze. The seed should be pierced in one spot with a file and soaked in tepid water for 24 hours before sowing. Sow early. Pkt. 10c.; $1 / 20 z$. $50 \mathrm{c}$; oz. $85 \mathrm{c}$.

814. Calliopsis, Tall Single, Mixed. Pkt. 10c. 


\section{Canterbury Bells}

819. Campanula medium, Single, Mixed. B. Beautiful bell-like flowers of blue, pink, and white in early summer. A splendid border plant. $2 \mathrm{ft}$. Pkt. 10c; 1/40z. 30c.; $1 / 2$ Oz. $50 \mathrm{c}$; Oz. $85 \mathrm{c}$

1014. Annual Canterbury Bells, Mixed. A. Blooms in less than 5 months after sowing and by successive plantings one can have Canterbury Bells right up to frost. A mixture of various shades of blue, pink, rose, and white. 2 ft. Pkt. 10c.; 1/10z. 20c.; 1/20z. 35c,; oz. 65c.

\section{Centaurea Cyanus}

(Bachelor's Button; Cornflower; Ragged Robin, etc.) A. Splendid annuals for cutting. They bloom all summer and fall and are easy to grow.

806. Double Blue. Deep blue. $2 \mathrm{ft}$.

804. Pinkie. Double; deep pink. $2 \mathrm{ft}$.

792. Red Boy. Double; red. $2 \mathrm{ft}$

Any of above Centaureas, pkt. 10c.; 1/20z. 25c.; oz. 40c. 807. Double, Mixed. All colors. 2 ft. Pkt. 5c.; 1/20z. 20c.; 949. Jubilee Gem. Dwarf, compact plant only 10 to 15 inches tall. Dark cornflower-blue flowers in profusion. A splendid bedder. Pkt. 10c.; 1/80z. 30c.;1/40z. 50c.; $1 / 20 z .85$ c.

\section{Carnation A.}

821. Marguerite, Double, Mixed. Blooms in about 5 months from time seed is planted. Fragrant, double white, pink, crimson, and striped flowers. Pkt. 10c.; $1 / 4$ oz. 50c.; $1 / 20 \mathrm{oz}$. 90c.

\section{Cardinal Climber A.}

1013. Quamoclit Sloteri. A rapid-growing vine to 30 feet with fern-like foliage and a profusion of $11 / 2$-inch flowers of fiery cardinal-red from midsummer until frost. Pkt. 10c.; 1/40z. 35c.; oz. 60c.

\section{Celosia A.}

The Cockscombs and Woolflowers are spectacular annuals especially desirable to dry for winter.

828. Cockscomb, Mixed (Celosia cristata), Dwarf, leafy plants with immense combs in shades of red, pink, and yellow. Cut before they are fully mature for drying. Pkt. 10c.; $1 / 8 \mathrm{Oz} .30 \mathrm{c}$; $1 / 1 / 4 \mathrm{Oz}$. 50c.

824. Chinese Woolflower (C. Cbildsi). Two-foot plants each branch tipped with a flower-head resembling a bal of bright red wool. Pkt. 10c; $1 / 80 \mathrm{z} .25 \mathrm{c} ; 1 / 4 \mathrm{Oz} .40 \mathrm{c}$.

\section{Cheiranthus $\mathrm{P}$.}

1055. Allioni (Siberian Wallflower). The seed of this hardy plant can be sown at any time of year. Springsown seed will bloom the frrst year. The 1 -foot plants bear bright orange flowers in profusion. Pkt. $10 \mathrm{c}$ $1 / 2$ Oz. 25c.; oz. 45 c.

\section{Chrysanthemum A.}

822. Carinatum, Mixed (Tricolor Chrysanthemum) Gorgeous single flowers on long stiff stems. Blooms during late summer and fall. Pkt, $10 \mathrm{c}, ; 1 / 20 \mathrm{z}, 25 \mathrm{c}$. oz. $40 \mathrm{c}$.

\section{Clarkia A.}

825. Elegans, Double, Mixed. An easy-growing annual with lovely flowers in a wide range of attractive colors. Likes some shade. Opens nicely when cut in bud stage. 2 ft. Pkt. 10c.; $1 / 4$ oz. 30c.; $1 / 20 z .50 c$.

\section{Cobaea A.}

827. Scandens (Cup-and-Saucer Vine), Lovely bellshaped blue flowers, changing to lilac, on a stronggrowing, prolific-blooming vine. Seeds should be planted edgewise. Pkt. 10c,; $1 / 40 z$. 30c.; $1 / 2$ oz. 50c.

\section{Coleus P.}

A foliage plant much used as a pot-plant for the house and during summer provides color for window-boxes and beds.

896. Rainbow Mixture. A true rainbow of color in a few plants. Pkt. 20 c.

\section{Coreopsis $\mathrm{P}$.}

A Iong-stemmed yellow flower in demand for cutting. Grows 2 feet tall and seeds itself if not kept cut.

831. Grandiflora, Double Sunburst. Double flowers, 2 inches in diameter, from June to October. A fine bedder for color as well as to cut. Pkt. 10c。: 1/40z, 35c. oz. \$1.25.

\section{The Everlastings}

Have you grown any of these lately? Don't forget they are splendid to use as fresh flowers as well as when dried for winter. Look up Celosia, Gomphrena, Gypsophila, Helichrysum, Lunaria, and Statice.

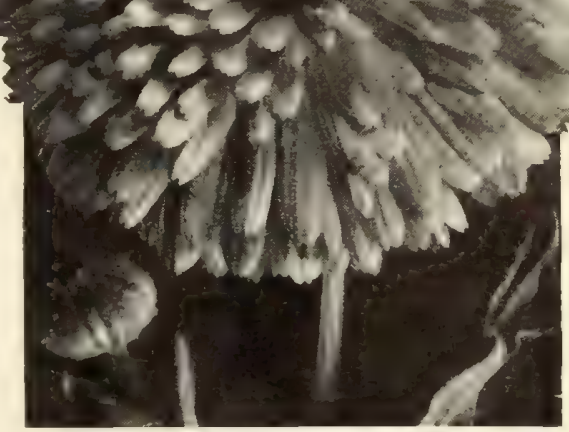

811. Calendula, Orange King Pkt. 10c.

825. Clarkia elegans, Double, Mixed. Pkt. 10c.

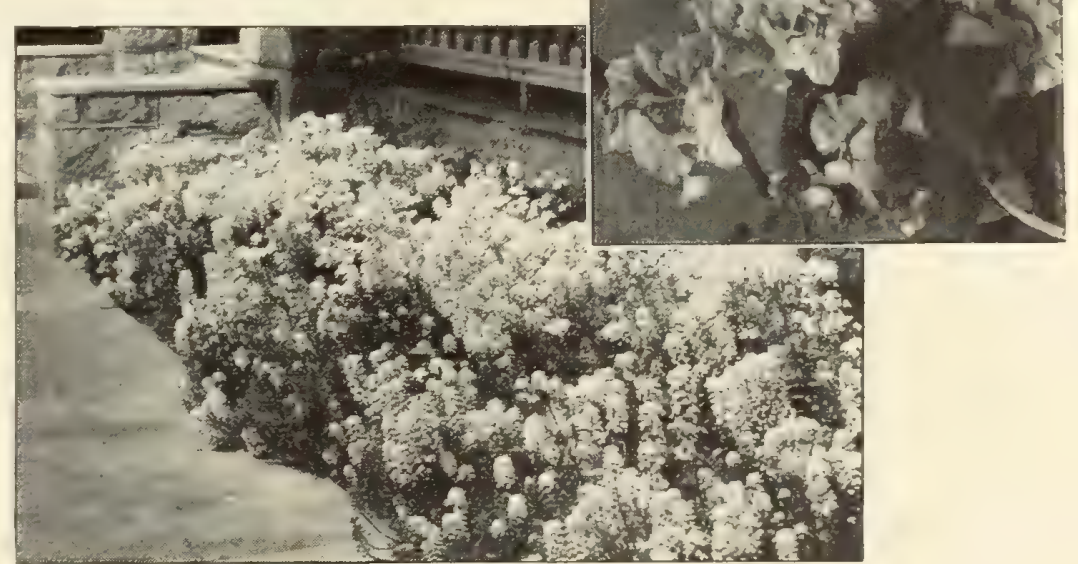

816. Candytuft, Giant Hyac-nth-flowered. Pkt. 10c.

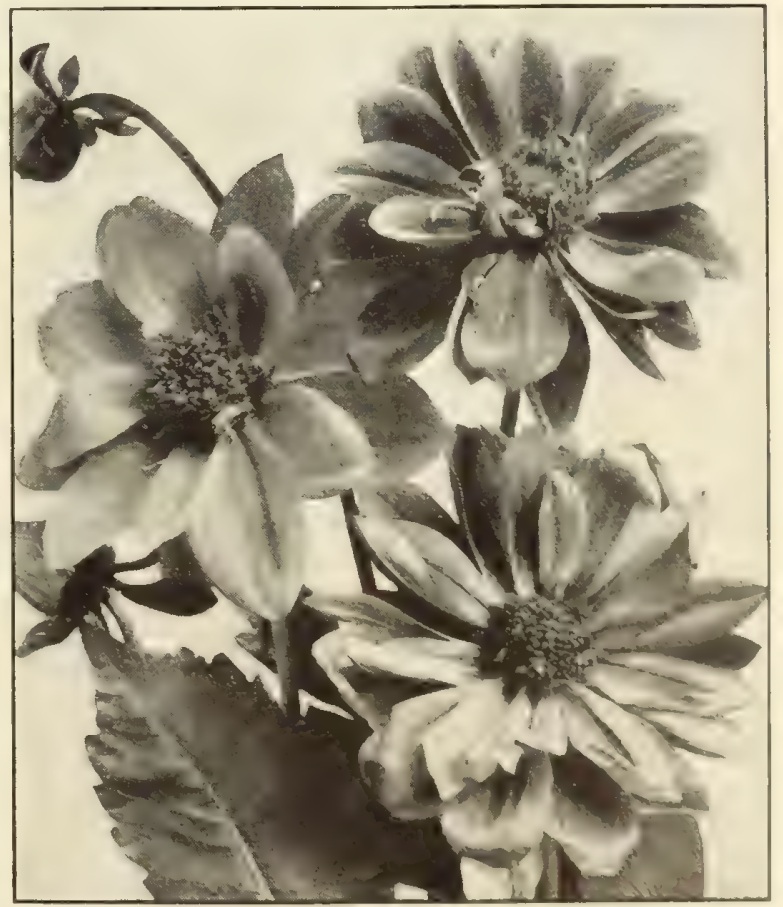

836. Dahlias, Unwin's Dwarf Hybrids. Pkt. 10c. 

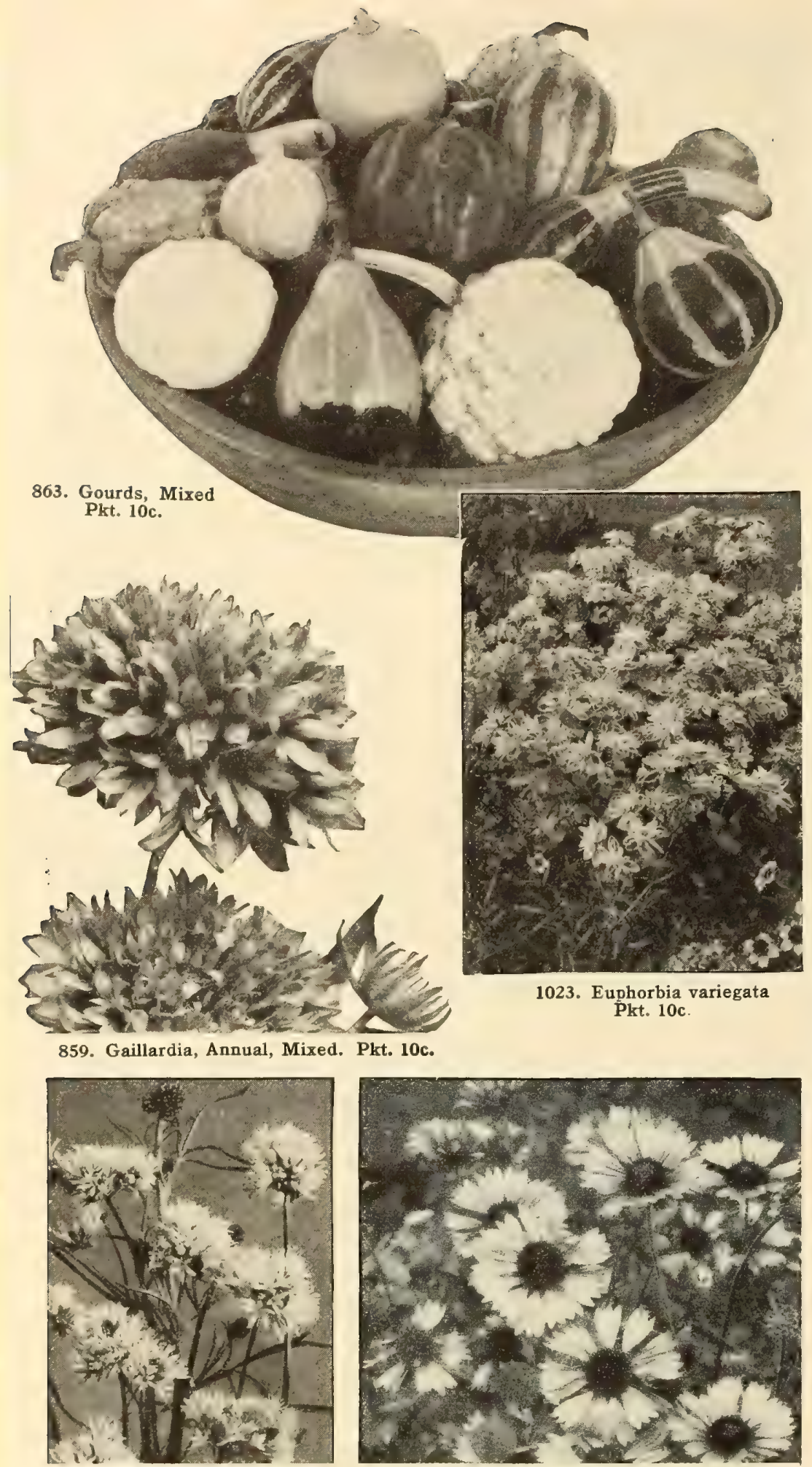

1060. Gilia capitata. Pkt. 10c.

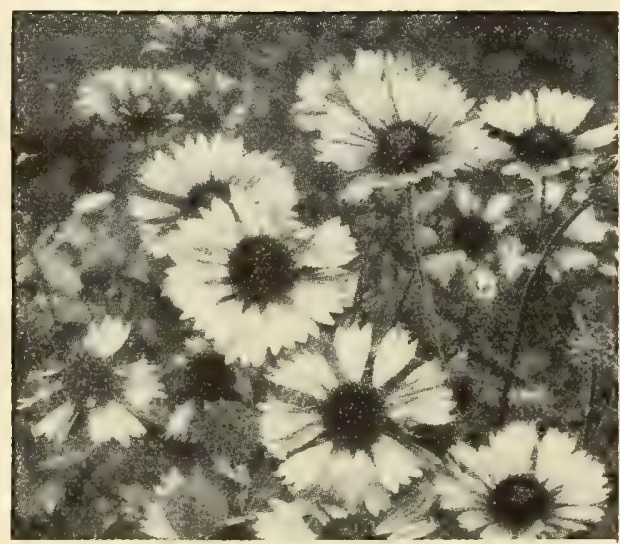

1048. Gaillardia, Indian Chief. Pkt. 10c.

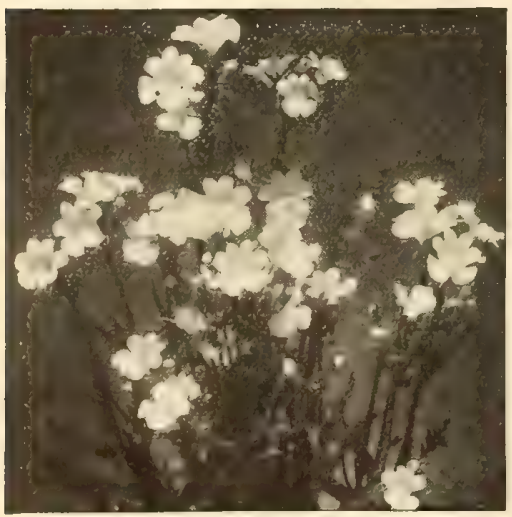

1061. Nemesia, Mixed. Pkt. 15c.

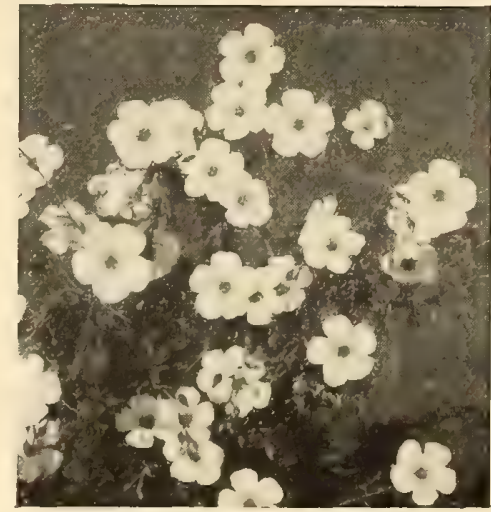

1033. Linum perenne. Pkt. 10c.

\section{Cosmos A.}

Tall, branching plants producing very desirable longstemmed flowers for cutting.

\section{EARLY-FLOWERING TYPES}

Giant Early-Flowering. The 3-foot plants bloom from July to frost with 3 -inch flowers.

838. Crimson.

837. Pink.

839. White.

Any of above Cosmos, pkt. 10c.; 1/20z. 25c.; 0z. 40c.

840. Mixed. Pkt. 5c.; 1/20z. 20c.; oz. 35c.; 1/4lb. \$1.25.

842. Early Double Crested, Mixed. Double or Anemoneflowered, beginning to bloom in July. $2 \frac{1}{2} \mathrm{ft}$. Pkt. $10 \mathrm{c}$.

843. Klondyke, Orange Flare. The $21 / 2$-foot plants bloom in less than 4 months, with single orange flowers. $\mathrm{plt} 10 \mathrm{c}, 1 / 4 \mathrm{oz} 20 \mathrm{c}, 1 / 20 \mathrm{z}, 35 \mathrm{c}, 60 \mathrm{c}$

948. Sensation, Finest Mixed. The 4 -foot plants bloom in 10 weeks from seed, with great 4 to 5 -inch single flowers in all the Cosmos colors. Pkt. 10c.; 1/40z. 25c.; $1 / 20 z, 45 c$

\section{LATE-FLOWERING TYPES}

1008. Late Double Crested. Flowers are like those of the Early Crested but plants are 4 feet tall and they do not bloom until later. Pkt. 10c.; 1/80z. 35c.; 1/40z. 65c.; $1 / 2 \mathrm{oz} . \$ 1.15$.

844. Late Mammoth Single, Mixed. Sown early in spring, these produce tall plants blooming all fall until frost. Pkt. 10c.: 1/2oz. 20c.; oz. 30c.; $1 / 4 \mathrm{Ib} . \$ 1.00$.

\section{Cynoglossum A.}

1016. Amabile (Chinese Forget-me-not). A fine bedding plant with fragrant, forget-me-not-like flowers which are good for cutting. $1 \frac{1}{2} \mathrm{ft}$. Pkt. $10 \mathrm{c}$; $1 / 4 \mathrm{Oz}, 25 \mathrm{c}$; oz. 45c.

\section{Cypress Vine (Ipomoea Quamoclit) A.}

833. Mixed. A fast-growing vine to 15 feet. Attractive fern-like foliage. Seeds are hard and should be soaked in warm water before planting. White and shades of red. Pkt. 10c.; $1 / 2$ oz. 30c.; oz. 50c.

\section{Dahlia A.}

Raising Dahlias from seed is an adventure as every plant will produce different flowers and there will be severa from each packet of seeds that you will want to carry over

834. Exhibition Strain, Mixed. A mixture of Cactus, Decorative, and Peony types. Pkt. 10c.; $\frac{1}{16} \mathrm{oz}$. $40 \mathrm{c}$.

836. Unwin's Dwarf Hybrids. Plants $11 / 2$ to 2 feet tall with 3-inch semi-double flowers from July on in a wide range of colors. Pkt. 10c.; 1/8oz. 50c.

\section{Daisies $P$.}

845. Double English, Mixed (Bellis perennis) R-G Lovely double flowers in profusion in early spring on low plants. Will need protection over winter. Pkt. 20c.

846. Shasta Daisy, Alaska. The 2-foot plants bear Iarge white Daisies about 5 inches across. They are splendid long lasting cut-flowers. Blooms all summer. Pkt. 10c.; $1 / 4$ Oz. 40c.; $1 / 2$ oz. 75c.

\section{Delphinium P.}

One of the frnest groups of garden flowers. The hybrids furnish long spikes of showy flowers for exhibition and the others splendid cut-flower material for mixed bouquets.

854. Belladonna. Clear turquoise-blue flowers on branching 5-foot plants. The everblooming Delphinium. Pkt. 15 c.; $1 / 8$ oz. 45c.; $1 / 4$ oz. 70c.; $1 / 20 z$ oz $\$ 1.25$.

862. Bellamosum. A dark blue form of the above. Pkt.

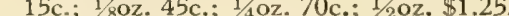

852. Chinensis, Mixed, R-G. Although a perennial, this will bloom in August from early spring planting. A nice border plant and good for cutting. Pkt. 10c.; $1 / 40 z$. 25c.; $1 / 20 z$. $40 \mathrm{c}$ : oz $75 \mathrm{c}$.

853. Gold Medal Hybrids. A mixture of taII, Iarge-flowering varieties. Long spikes in shades of blue make this a good background plant. 4 to $6 \mathrm{ft}$. Pkt. 10c.; 1/8oz. 30c.;

1067. Pacific Hybrids, Mixed. Delphinium lovers pronounce these the frnest Delphinium grown. They are truly giants, usually 6 feet or more, with strong stems and spikes of lovely flowers as large as a silver dollar. Plants are practically immune to mildew and are the healthiest Delphinium we have seen. All the Delphinium colors will be found in this mixture. Pkt. $50 \mathrm{c}$; $\frac{2}{16} \mathrm{Oz}$. $\$ 1.50$.

\section{ALL PRICES SUBJECT TO MARKET CHANGES}


Dianthus (Pinks) A., P., R-G.

Brilliant flowers all summer and fall. Most varieties are about a foot tall, are splendid bed and border plants, frne rock-garden specimens and desirable for cutting.

849. Annual Pinks, Double, Mixed. A. Lovely fringed flowers of all colors. Pkt. 10c.; 1/40z. 25c.; 1/20z. 45c.; oz. $75 \mathrm{c}$

850. Annual Pinks, Single, Mixed. A. Large flowers 2 to 3 inches across, brilliantly colored and delightfully cut and fringed. Pkt. 10c.; $1 / 2 \mathrm{Oz} .35 \mathrm{c}$; $0 \mathrm{z} .60 \mathrm{c}$.

851. Plumarius (Pheasant's Eye). P. Single, fringed, clove-scented flowers of pink and white in great profusion during May and June. Low, spreading plants. Pkt. 10c.; $1 / 2$ oz. 35c; oz. $60 \mathrm{c}$.

\section{Digitalis (Foxglove) B.}

1021. Gloxiniæflora. Plants 3 to 4 feet high with long spikes of tubular, thimble-like flowers of various colors. The "thimbles" are heavily spotted inside. Pkt, 10c.; $1 / 8$ oz. 25c.; $1 / 4$ oz. 40c.; $1 / 2$ oz. $75 \mathrm{c}$.

Dimorphotheca aurantiaca (African Daisy) A. 1017. Golden West. The $2 \frac{1}{2}$-inch golden flowers have a dark disk and halo. Nice cut-flowers. They need a dry, 15 in. Pkt. 10c.; $1 / 8$ oz. 30c.; $1 / 4$ oz. 50c.; $1 / 20 z$. 85c.

\section{Eschscholtzia (California Poppy) A., R-G.}

Easily-grown annuals to be sown where they are to remain and thin to stand 12 inches apart. Do not try to transplant them. Plants are low and spreading, with finecut foliage. Blooms all summer.

1009. Golden West. Bright yellow flowers with orange

855. Mixed. A wide range of colors including shades of crimson, pink, and orange-scarlet.

Any of above Eschscholtzia, pkt. 10c; 1/2oz. 30c.; oz. 50c.

\section{Euphorbia A., R-G.}

1023. Variegata (Snow-on-the-Mountain). Plants grow to 2 feet and have green foliage margined with white. A popular border plant. Pkt. $10 \mathrm{c}$; $1 / 2 \mathrm{oz} .25 \mathrm{c}$; oz. $40 \mathrm{c}$.

\section{Feverfew $P$.}

856. Alba plenissima. Two-foot plants with dark cut foliage and small, double, white flowers on good cutting stems. Pkt. 10c.; $1 / 4$ oz. 35c.; oz. \$1.25.

\section{Forget-Me-Not P., R-G.}

858. Myosotis alpestris. A Iovely April-blooming, dwarf plant with blue flowers, useful for carpeting and planting among tulips. Prefers moist soil. Pkt. 15c.; $1 / 8$ oz. 50c. $1 / 4 \mathrm{Oz} .90 \mathrm{c}$.

\section{Four o'Clock (Marvel of Peru) A.}

857. Mirabilis Jalapa. Bushy plants to $2 \frac{1}{2}$ feet with myriads of red, yellow or white flowers. They get their name from the fact that the flowers open at about 4 P.M. standard time. Pkt. 5c.; oz. 25c;; 1/4lb. 75c.

\section{Gaillardia (Blanket Flower) A., P.}

Border and bedding plants with showy flowers useful for cutting. They bloom from early summer into fall.

1048. Indian Chief. A. Single, bronzy red flowers. A lovely cut-flower. Pkt. 10c.; $1 / 40 \mathrm{oz} .25 \mathrm{c}$; $1 / 2 \mathrm{oz}$. 40c.

859. Annual, Mixed. A. A fine mixture with reds and yellows predominating. Pkt. 10c.; $1 / 4 \mathrm{oz} .25 \mathrm{c}$; $1 / 2 \mathrm{oz}, 40 \mathrm{c}$.

989. The Dazzler. P. Large flowers of dark red with orange petal-tips. Striking. Pkt. 10c.; 1/40z. 50c

860. Grandiflora, Mixed. P. Lovely single flowers with centers of shades of red and the outer petals yellow. Will bloom first year if planted early. Pkt. 10c.; $1 / 40 z$. $35 \mathrm{c} ; 1 / 2 \mathrm{oz} .60 \mathrm{c}$

\section{Geranium zonale P.}

861. Mixed. Treated as an annual when planted from seed as a garden plant but plants can be lifted and carried over winter indoors. Seed saved from choice varieties. Pkt. 15c.; $\frac{1}{16} \mathrm{Oz} .50 \mathrm{c}$.

\section{Gilia A.}

1060. Capitata. A splendid annual about 2 feet tall with lovely lavender-blue flowers. Pkt. 10c.; $1 / 40 \mathrm{Oz} .25 \mathrm{c}$.; $1 / 2 \mathrm{oz} .40 \mathrm{c}$.
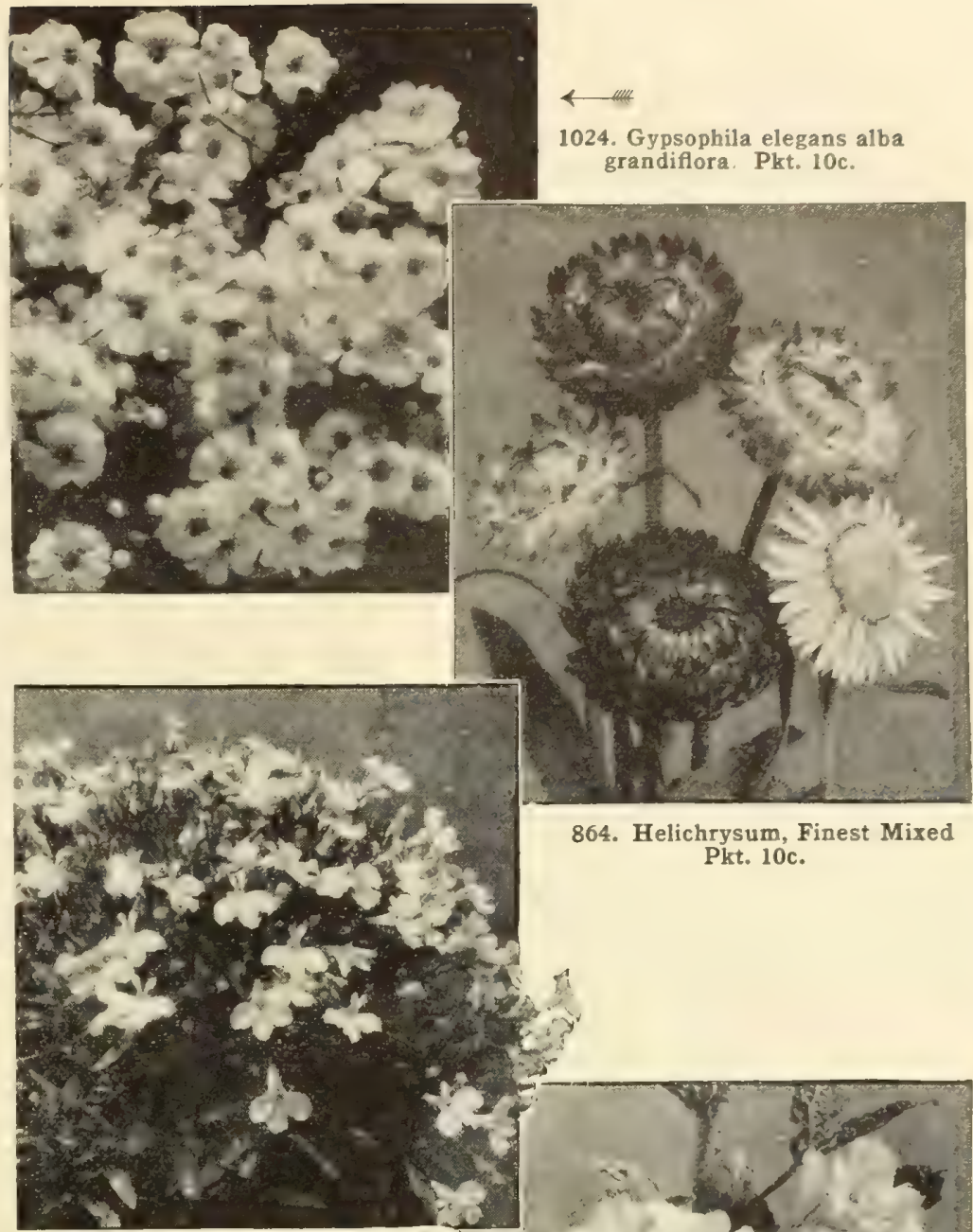

864. Helichrysum, Finest Mixed Pkt. 10c.

878. Lobelia, Compact, Dwarf, Mixed. Pkt. 10c.
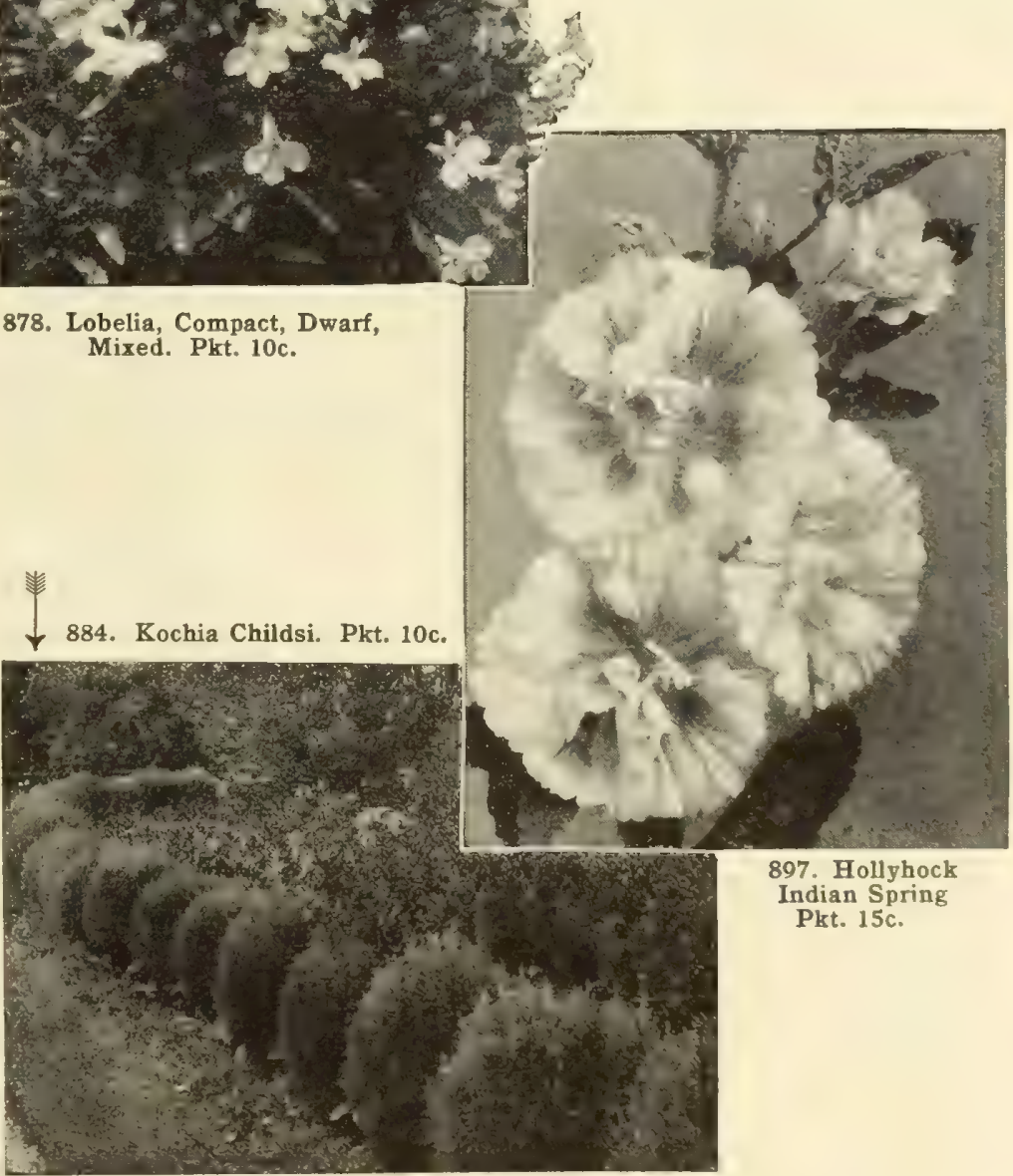

Fragrance

Do you grow flowers just to look at, or must they smell good, ton?

Mignonette with its unforgettable sweetness is not much to look at, it would soon disappear from gardens if it should lose its fragrance, while Heliotrope, another wonderfully fragrant flower, pleases as well with its beauty.

Increase your garden pleasure by studying your flowers and grow for fragrance as well as beauty. 


\section{Kochia A.}

884. Childsi (Burning Bush; Summer Cypress). Pyramidal bush $2 \frac{1}{2}$ feet high, with feathery light green foliage which turns crimson in early autumn. Flowers are unimportant but plants make a lovely hedge. Pkt. $10 \mathrm{c} . ; 0 z .25 \mathrm{c}$

\section{Kudzu Vine P.}

872. Pueraria Thunbergiana. A remarkable vine which in rood soil will grow a foot a day until it reaches 50 feet or more. Fragrant purple flowers in late summer are followed by hairy seed-pods. Pkt. 10c.; 1/40z. 40c.

\section{Lantana A.}

873. Mixed. A splendid bedding plant with verbena-like heads of colorful flowers all summer. Also a splendid pot-plant for the house. Good mixture of colors. Pkt. 10 c.; $1 / 4$ oz. 50c.

\section{Larkspur A.}

\section{DOUBLE GIANT IMPERIAL}

A base-branching type growing 3 to 4 feet tall and providing long-stemmed spikes of double flowers for cutting.

1029. Blue Bell. A fine medium blue between lilac and sky-blue. A beautiful Larkspur.

1020. Mixed. Good mixture of colors.

Any of above Larkspurs, pkt. 10c.; $1 / 40 \mathrm{z}, 35 \mathrm{c}$; $1 / 20 \mathrm{z}$. $65 \mathrm{c} . ;$ oz. $\$ 1.25$

\section{TALL DOUBLE STOCK-FLOWERED}

Plants 3 to 4 feet high with long spikes of double flowers. Fine for garden color and cutting

874. Azure-Blue.

900. Dark Blue.

875. Lilac.

876. Scarlet-Rose.

1032. White.

Any of above Larkspurs, pkt. 10c.; 1/40z. 25c.; $1 / 20 z$. 40c.; 0z, 75c.

877. Mixed. Pkt. 5c.;1/40z. 20c.; 1/20z. 35c.; oz. 60c

\section{Lathyrus $\mathrm{P}$.}

1036. Latifolius, Mixed (Everlasting or Perennial Pea). Hardy perennial climber growing to 8 feet and getting better every year. Blooms are not fragrant but make good cut-flowers in early spring. Good range of colors. Pkt. 10c.; $1 / 40 z$. . 30c; $1 / 20 z$. 50c.; oz. 90 c.

\section{Linum P, R-G.}

1033. Perenne. Dainty sky-blue flowers on $11 / 2$-foot plants from May to August. Pkt. 10c.; 1/20z. 25c.; oz. 45c.

\section{Linaria (Toadflax) A., R-G.}

926. Maroccana Hybrids. Miniature snapdragon-like fowers in bright and pastel shades on 12 to 18 -inch plants. Also makes a nice pot-plant. Pkt. 10c.; $1 / 4 \mathrm{Oz}$. $25 \mathrm{c} ; 1 / 20 \mathrm{z}, 45 \mathrm{c}$

\section{Lobelia A., R-G.}

878. Compact and Dwarf Mixture. This mixture is made up of varieties especially desirable for edging, rock-gardens, window-boxes, hanging-baskets and winter house-plants. The plants, to 6 inches high, bear lovely little flowers in shades of blue. Pkt. 10c.; $\frac{1}{16} \mathrm{Oz} .30 \mathrm{c}$.

\section{Lunaria $B$.}

835. Annua (Honesty; Money Plant). Bushy plants, 11/2 to 2 feet tall, bear lilac-purple flowers in profusion fol lowed by silvery seed-pods desirable for winter bouquets. Pkt. 10c.; 1/80z, 35c.; 1/40z. 65c.

\section{Lupinus $P$.}

879. Polyphyllus, Mixed. Plants 2 to 4 feet, with long spikes of flowers resembling sweet peas. An excellent sarden decorative and cut-flower. Should be sown where plants are to stand as they do not transplant well. Good mixture of colors. Pkt. 10c.; $1 / 8 \mathrm{oz}$. 35c.; 1/40z. 60c.

\section{Mignonette (Reseda odorata) A.}

An old-fashioned flower loved for its exquisite fragrance and should be in every garden. Does best in cool weather and a second planting should be made in August for autumn bloom. Sow where it is to grow.

885. Machet. Plants 12 inches high with reddish flowers of extra sweetness. Pkt, 10c.; 1/20z, 30c; oz, 50c.

WASHINGTON, D. C.

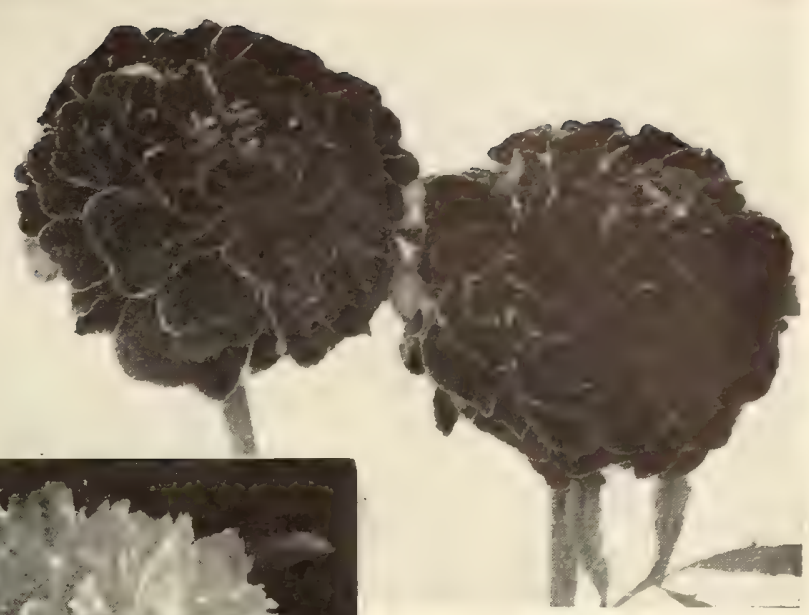

883. Marigold, Dwarf Double French, Mixed Pkt. 5c

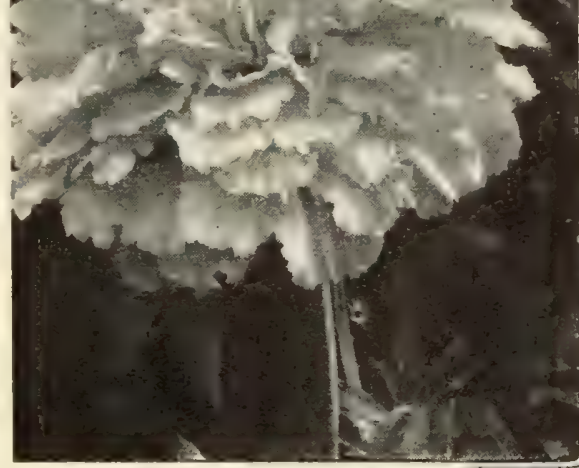

823. Marigold, Yellow Supreme
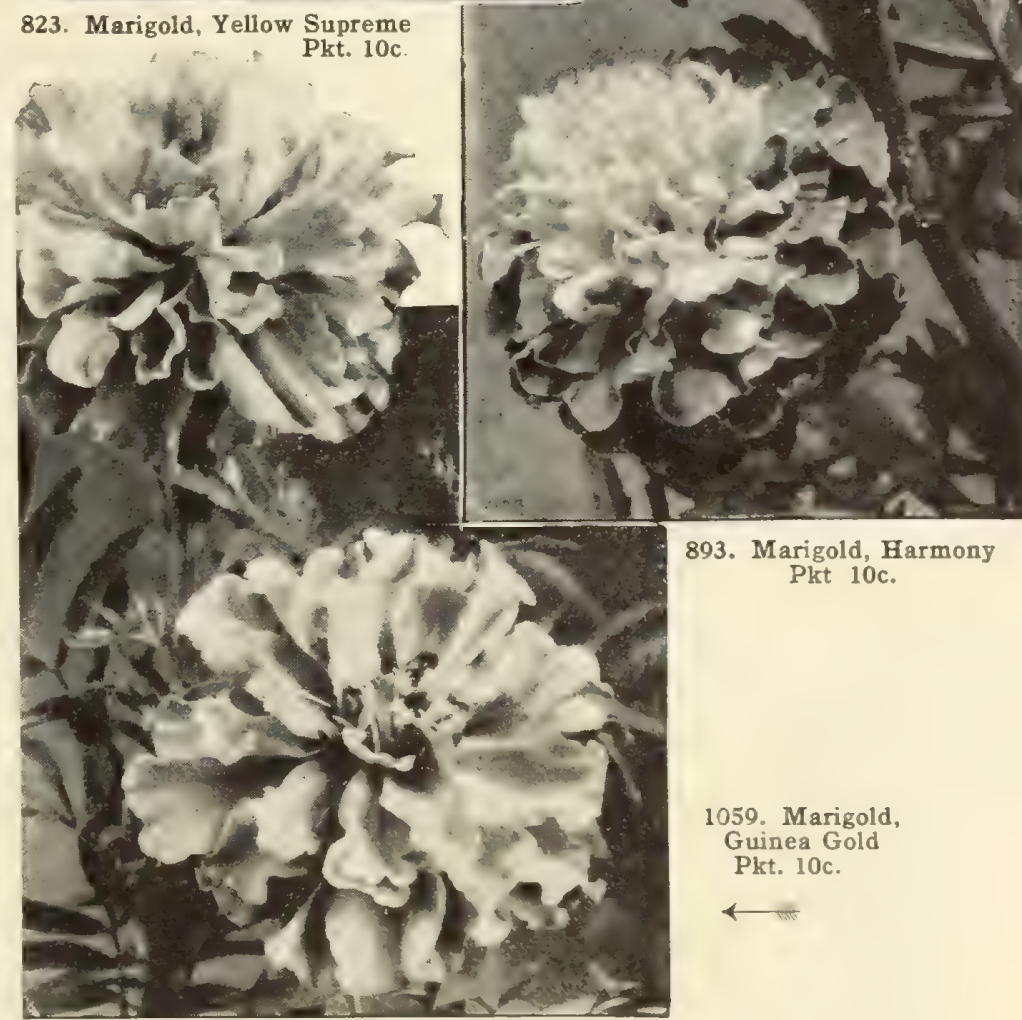

1059. Marigold,

Guinea Gold

Pkt. 10c.

$\leftarrow$

\section{Marigolds}

Like Petunias and Zinnias, the Marigold is another annual family with members for many uses.

For rich yellows and oranges the Marigolds are unsurpassed, and a bed of one variety of the dwarf French type of the Harmony group provides color in mass over a long period with little care, while the tall varieties furnish long-stemmed flowers to cut. 


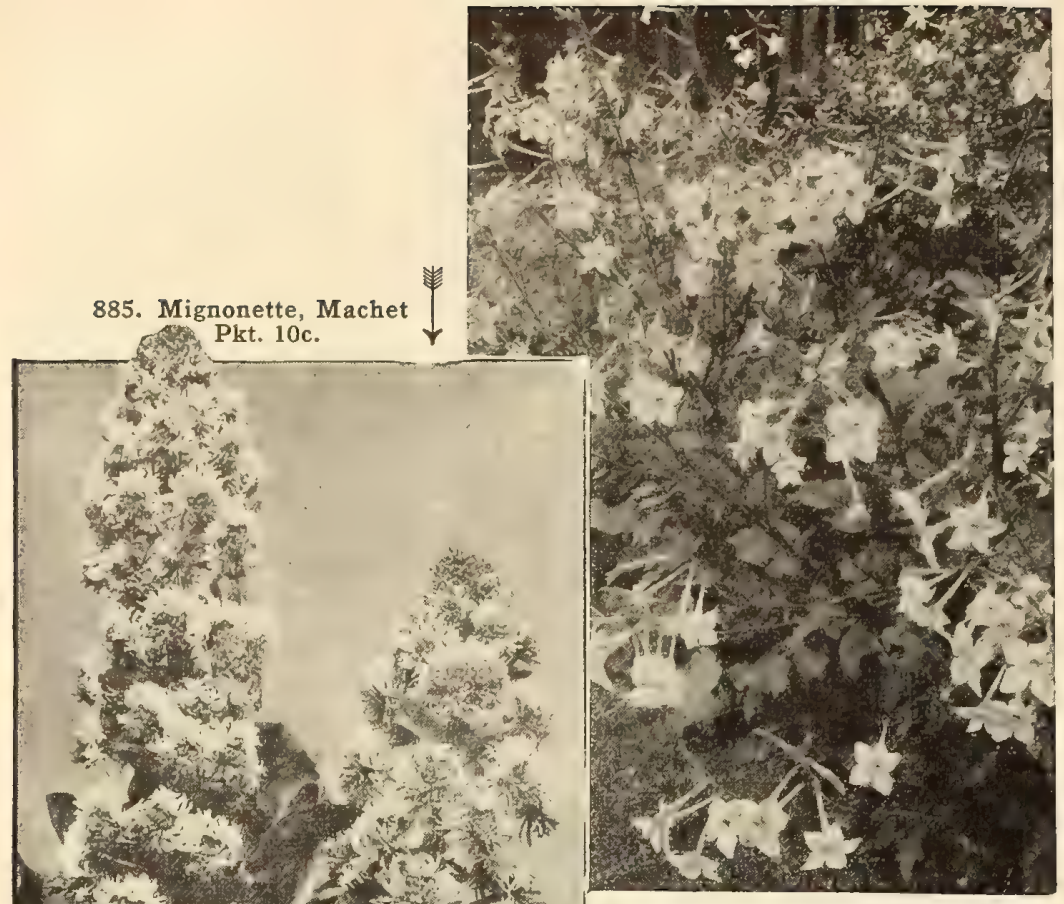

6 ang

1035. Nicotiana Hybrids, Mixed Pkt. 10c.
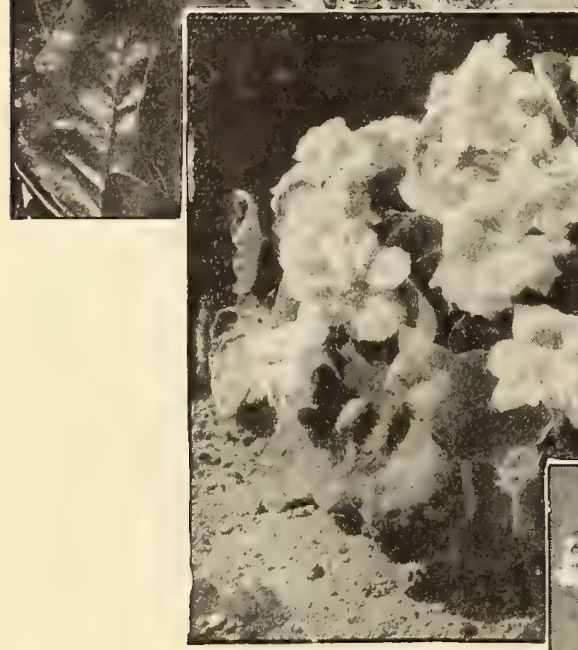
Golden Globe Pkt. 10c.
888. Nasturtiums,

\section{Marigolds A.}

Favorite annuals thriving in almost any ground and providing quantities of bloom for garden color and long-

951. Crown of Gold. Bright golden orange flowers $21 / 2$ inches across. Short quilled center petals are surrounded by flat guard petals. Fragrant. $21 / 2 \mathrm{ft}$. Pkt. 10c.; $1 / \frac{1}{\mathrm{O}} \mathrm{z}$. 93. Ferdinand. Two-foot plants with single flowers having a crested center of golden yellow surrounded by a row of broad mahogany-red petals. An excellent cutflower. Pkt. 15c.; 1/40z. 35c.; 1/20z. 65c.

952. Gigantea, Sunset Giants. Great 5 to 6 -inch fragrant, double flowers in shades of orange, yellow, lemon and primrose. Strong 3-foot plants. Pkt. 10c.; 1/8oz. 25c.; $1 / 40 z .40 \mathrm{c}$; $1 / 2 \mathrm{oz}$. $75 \mathrm{c}$

893. Harmony. Beautiful scabiosa-shaped, double flowers of deep orange with a collar of maroon petals. Plants grow about a foot tall and bloom freely, making it an ideal bedding variety for garden color, for spots in the border and for cutting. Pkt. 10c.; 1/4oz. 25c.; 1/20z. 40c. Sunrise. An early-blooming form of Dixie Sunshine. Dazzling golden yellow ball-shaped blooms on 3-foot bushy plants. Gives a long season of bloom. Pkt. 15c.;

921. Yellow Pygmy. One-inch flowers of Iight lemon883. Dwarf Double French, Mixed. Splendid freeblooming bedding type about a foot tall. A real treasure. Pkt. 5c.; $1 / 2$ oz. 35c.; oz. 50c.

\section{TALL AFRICAN DOUBLE VARIETIES}

Well-known varieties of the Tall Africans growing $21 / 2$ to 3 feet tall and providing quantities of long-stemmed flowers for cutting.

1059. Guinea Gold. Ruffly flowers of golden yellow. P8t. Lemon Ball. Pure canary-gold. Pkt. 10c.; $1 / 4 \mathrm{oz} .40 \mathrm{c}$;
8. 881. Orange Ball. Orange-yellow. Pkt. 10c.; $1 / 4 \mathrm{oz} .40 \mathrm{c}$. 823. Yellow Supreme. Lemon-yellow. Honey fragrance. Pkt. 10c.; 1/40z. 30c. 1/20z. 50c.

882. Mixed. Tall; doubles. Pkt. 5c.; $1 / 40 z .25 c$; $1 / 20 z$ $40 \mathrm{c}$; oz. $75 \mathrm{c}$

\section{Morning-Glory (Ipomoea) A.}

Vigorous vines with lovely large flowers open in early morning and all day during cloudy days. Plant in poor soil for best bloom. Soak or ffle seeds for good germination. 815. Heavenly Blue. Blooms 3-inch diameter, of clear blue, in profusion. Pkt. 10c.; $1 / 4 \mathrm{oz}$. 35c.; $1 / 2 \mathrm{oz}$. 60c.

997. Heavenly Blue, Clark's Variety. An earlier blooming variety with somewhat larger flowers. Pkt. 10c. 1/40z. 35c.; 1/20z. 60c.; oz. $\$ 1.00$

887. Imperial, Mixed. Large flowers of many colors. Pkt. 10c.; $1 / 2$ oz. 30c.; oz. 50c; 1 1/4tb. $\$ 1.50$

886. Moonflower. Large white flowers open at night and

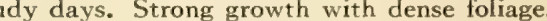
Pkt. 10c.; $1 / 2$ oz. 25c.; oz. 45c.; $1 / 4$ lb. $\$ 1.25$.

1015. Pearly Gates. Silver Medal, 1942 All-America Selections. A sport of Clark's Heavenly Blue, identical in every. way except color of flowers which are satiny white with a creamy throat. Pkt. 25c.; 1/80z. 35c.; $1 / 4$ oz. $60 \mathrm{c}$; oz, $\$ 1.00$.

899. Scarlett O'Hara. Gold MedaI, 1939 All-America Selections. An early variety blooming in about 65 days from seed. The $31 / 2$-inch flowers are dark wine-red. A strong-growing plant. Pkt. 10c.; 1/80z. 30c.; 1/40z. 50c.; oz. $90 \mathrm{c}$.

\section{Nemesia A.}

1061. Mixed. Excellent bedding plants to 1 foot high with attractive flowers in a wide range of colors. Pkt. 15c.; $\frac{1}{16}$ oz. $25 \mathrm{c}$.; $1 / 8 \mathrm{Oz}$. $45 \mathrm{c}$.

1062. Nemophila, Mixed Pkt. 10c.

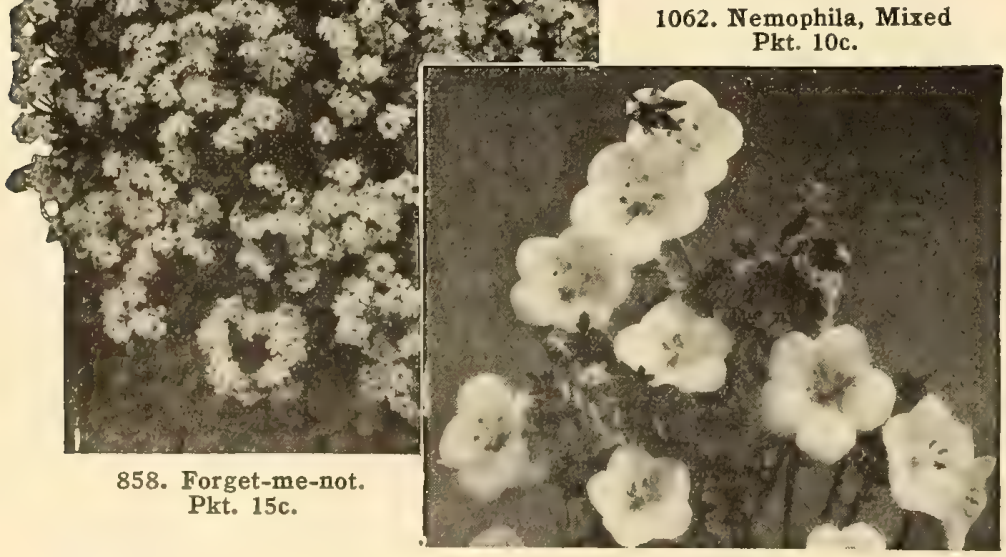

\section{Nemophila A.}

1062. Mixed. Bright light blue flowers on 8-inch plants. Makes a nice bed. Pkt. 10c.; 1/40z. 25c.; 1/20z. 45c.

\section{Nicotiana (Flowering Tobacco) A.}

1063. Affinis. Fragrant, star-shaped, pure white flowers all summer and fall. 2 to $3 \mathrm{ft}$. Pkt. 10c.; $1 / 40 \mathrm{oz}$. 25c.; $1 / 2 \mathrm{Oz}$. $40 \mathrm{c}$

1035. Hybrids, Mixed. Showy 2 to 3 -foot plants with fragrant flowers in a variety of colors. Pkt. 10c.; $1 / 20 z$. $30 \mathrm{c}$; ; oz. $50 \mathrm{c}$

ALL PRICES ARE SUBJECT TO MARKET CHANGES

$$
\text { F. W. BOLGIANO \& CO,, INC. }
$$




\section{Nasturtiums A.}

Lovely annuals thriving on poor sandy soil and coming into bloom within a few weeks after sowing. Keep plants free of black aphis by spraying with Black-Leaf 40 or one of the aphis destroyers listed in the Catalogue. The green seeds are used for peppery pickles.

\section{DWARF VARIETIES. $1 \mathrm{ft}$.}

888. Golden Globe. Compact little plants with semidouble, fragrant flowers of bright golden yellow. Pkt. $10 \mathrm{c}$; $1 / 2$ oz. 20c.; oz. 35c.

953. Gem Mixture. Sweet-scented, semi-double flowers in a fine mixture of light and dark colors. Compact, dwarf plants. Pkt. 10c; $1 / 20 z$. 20c.; oz. 35c.

890. Single, Mixed. Splendid mixture of truly dwarf singles. A good companion to the Gem Mixture of semidoubles. Pkt. 5c.; oz. 15c.; 1/4lb. 50c.

\section{SEMI-DWARF VARIETIES. $11 / 2 \mathrm{ft}$.}

994. Golden Gleam. Large, golden yellow, semi-double, sweetly scented flowers on bushy plants with short runners. Pkt, 10c.; 1/20z. 20c.; oz. 35c.

1027. Scarlet Gleam. Fiery orange-scarlet, semi-double flowers to 3 inches across. Fine plants. Pkt. $10 \mathrm{c}$; $1 \frac{1}{2} \mathrm{oz}$. $25 \mathrm{c}$.; oz. $40 \mathrm{c}$.

1026. Gleam Hybrids. A mixture of all the Gleam varieties. Large flowers on good plants. Pkt. 10c.; $1 / 20 \mathrm{z}, 20 \mathrm{c}$; oz. 30c

\section{TALL VARIETY}

891. Tall, Mixed. The 8 to 10 -foot runners which can be trained to fences and trellises or spread over walls, etc. A wide range of colors. Pkt. 5c.; oz. 15c.; 1/4 Ib. 50c.

\section{Nierembergia A}

1068. Purple Robe. Bronze MedaI, 1942 All-America Selections. Cushion-like mats covered with lovely violet-blue cup-shaped flowers. A perennial in mild climates. Pkt. 25c.

\section{Pansies A., R-G.}

Pansies may be sown in August or September for early bloom the following spring or may be planted early in the spring for later bloom. Planting twice a year in this manner provides Pansies during most of the growing season. Seedlings from the late summer and fall planting should have some winter protection.

832. Coronation Gold. Large, golden yellow, round flowers with lightly ruffled edges. They have a spicy fragrance and are generously produced on stocky plants. Pkt. 20c.; $\frac{x}{16} \mathrm{Oz}$. 90c.

894. Giant Trimardeau, Mixed. This mixture has a wide range of colors and the large flowers have delightfully marked faces. Pkt. 10c.; 1/80z. 90c.; 1/4oz. $\$ 1.50 ; 1 / 2 \mathrm{Oz} . \$ 2.75$

995. Roggli Swiss Giants. Extremely large flowers of heavy texture and rich dark colors places this strain in front rank. Long, strong stems hold the flowers well above the foliage. Pkt. 25c.; 1/8 oz. \$1.75; 1/4oz. \$3.25. oz. $\$ 10.00$

\section{Petunias A.}

Truly everybody's flower. They are easy to grow and from early summer until frost they provide color in quantity. For bedding, for the border, window-box or potting, they are unsurpassed. There are many types of both plant and flower. All are beautiful; some of the new largeflowered varieties are sensational.

\section{BALCONY TYPES}

Large, single flowers. Plants of trailing habit with $11 / 2$ to 2 -foot runners.

901. Balcony, Blue.

1041. Baicony, Crimson.

902. Balcony, White.

Any of above Balcony Petunias, pkt. $15 \mathrm{c} ; \frac{1}{16}$ oz. 50c.

903. Balcony, Mixed. Pkt. 15c。; $\frac{1}{16} \mathrm{oz} .35 \mathrm{c} ; 1 / 8 \mathrm{oz} .65 \mathrm{c}$.

979. Blue Brocade. (All Double.) Silver Medal, 1941 AllAmerica Selections. Large, double, fringed flowers of deep violet-blue. They are about 4 inches across and are very fragrant. The stocky plants are about 1 foot high and bloom freely. Pkt. 50c.

1069. Cream Star. (Hybrida Nana Compacta.) Silver MedaI, All-America Selections. Dainty cream-white flowers marked with a deeper cream star. Compact 8 to 10 -inch plants hide themselves under their masses of bloom. Pkt. 25c.; $\frac{1}{16}$ Oz. 60c.
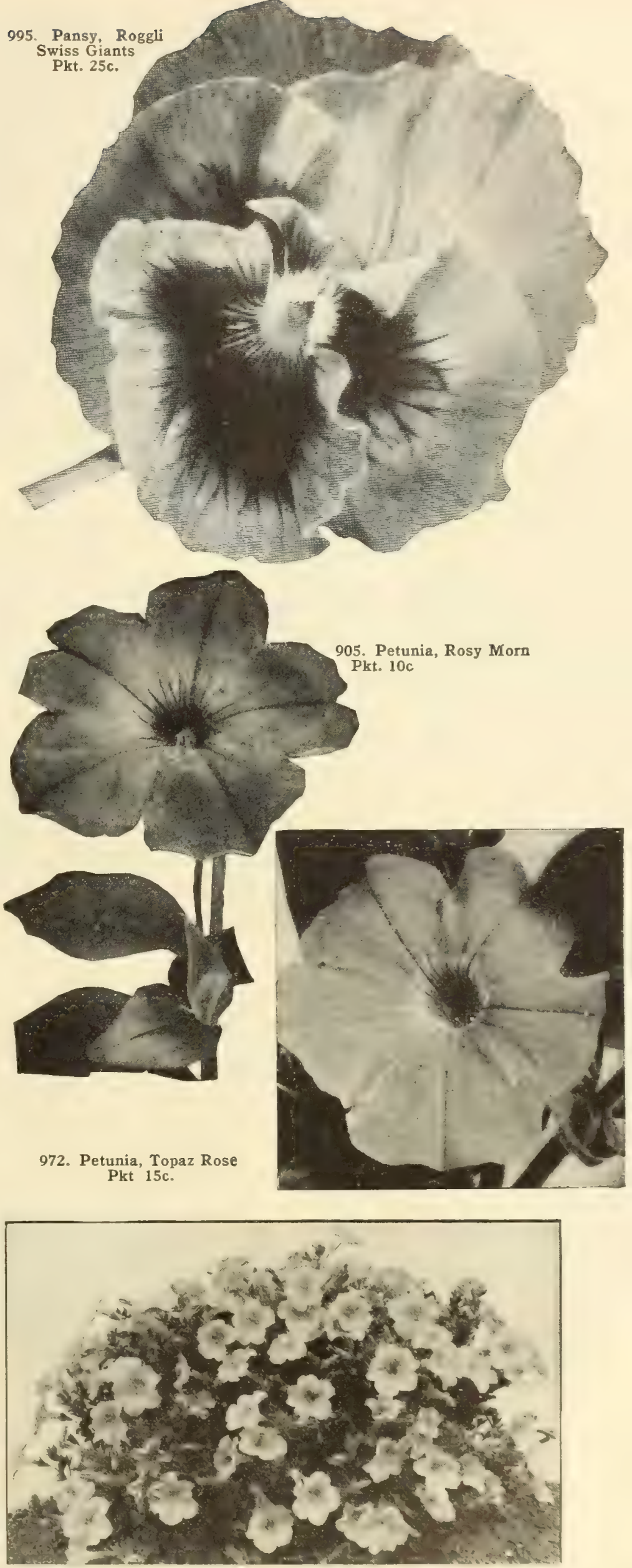

1064. Petunia, Single Dwarf Bedding, Igloo. 1943 All-America Winner. Pkt. 25c 


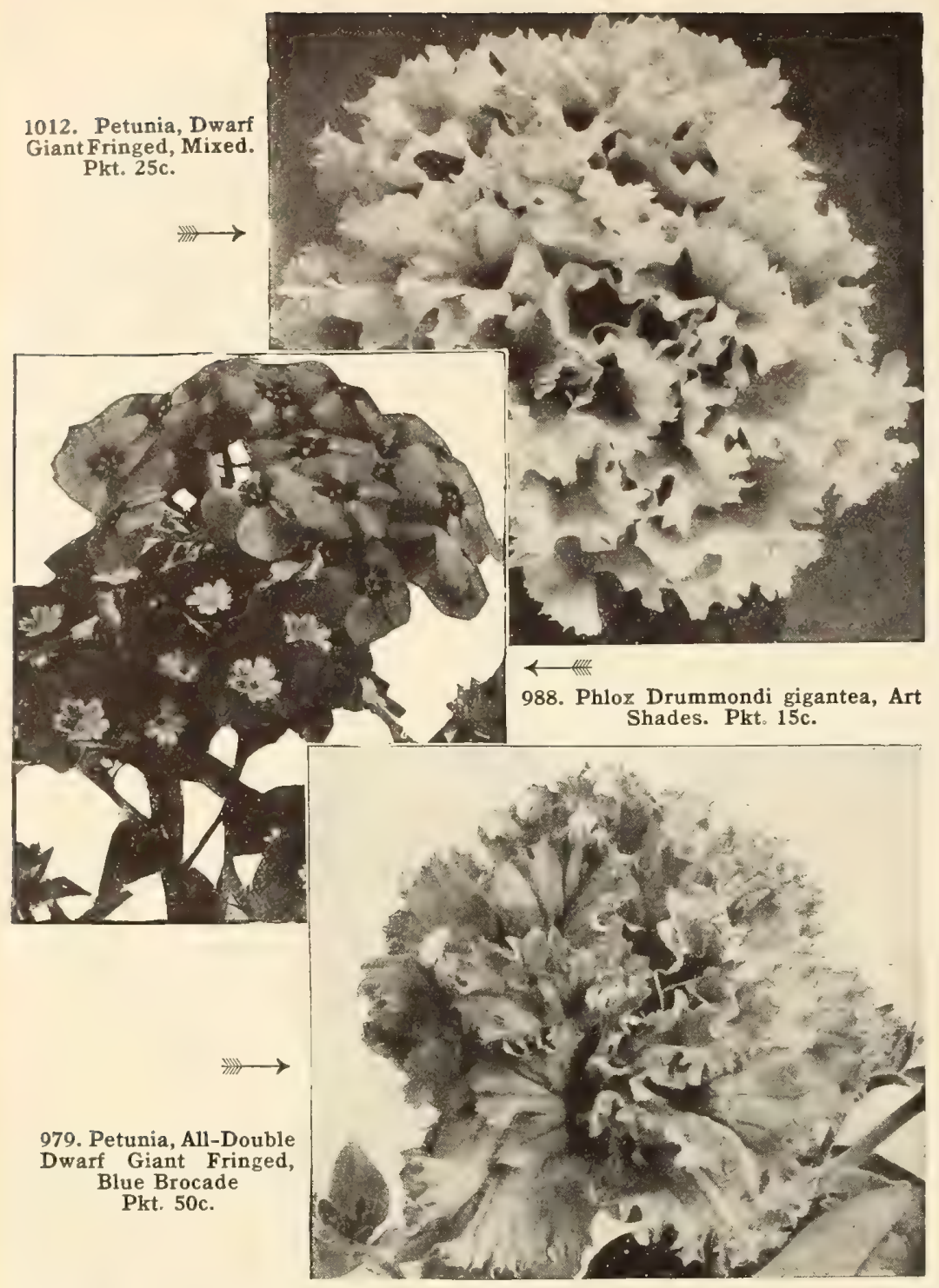

907. Petunia, Giants of California, Ruffled, Mixed. Pkt. 25c.

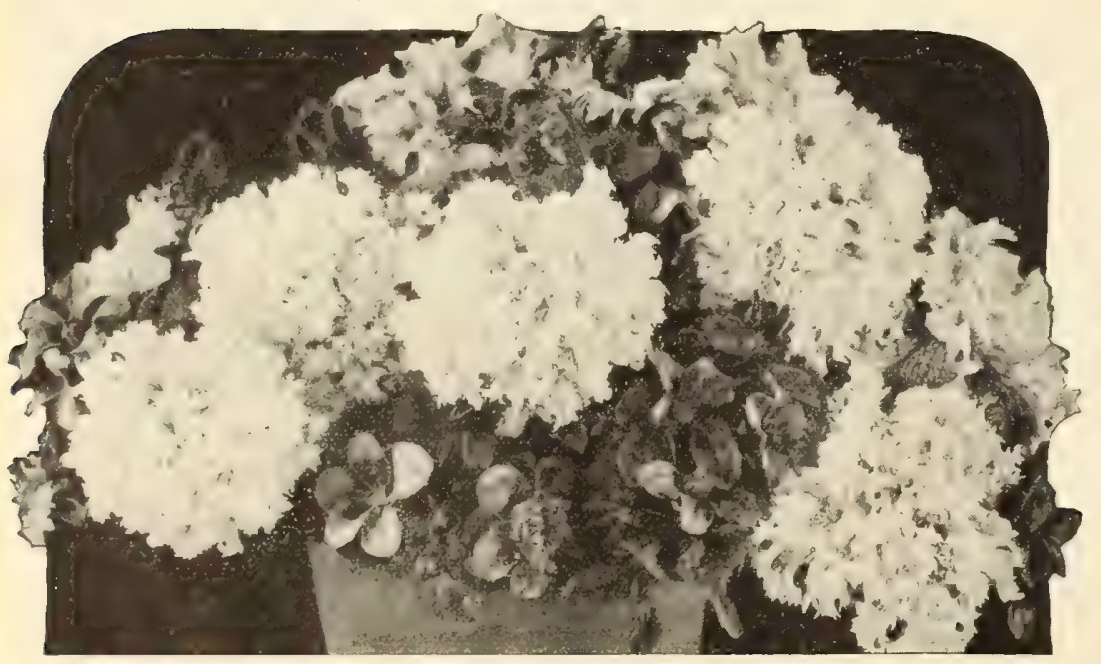

PETUNIAS

The Petunia is another of those important annuals of many uses. There are the large-flowered doubles so fine when grown in pots; the Balcony type, lovely in a hanging-basket or when drooping over the side of a window-box or garden urn. There are compact little bush kinds which look well at the edge of borders, while all types are delightful when planted in solid beds for masses of color.

Every garden needs lots of Petunias.
PETUNIAS, BALCONY TYPES, continued

1064. Igloo. Bronze Medal, 1943 All-America Selections. Compact 12-inch plants which cover themselves with

$11 / 2$-inch creamy white single flowers all season. A great Dewt. 25c.

1012. Dwarf Giants of California, Dark Shades. Dwarf, sturdy plants especially suited to pot-culture. Flowers are beautifully ruffled and fringed. Pkt. 25c.

1004. Elk's Pride. (Grandiflora.) Lovely large flowers of deep royal purple. Plants 12 to 16 inches high. Pkt. 25c. 1037. Flaming Velvet. (Hybrida.) The 18-inch plants have velvety red-blood single flowers. Pkt. 15c; $\frac{1}{160 z}$. 907. Giants of California Ruffled, Mixed. A wellbalanced mixture of large fringed and ruffled flowers of light and dark colors, including pink and rose shades with attractive throats. Pkt. 25c

904. Giant-flowered, Mixed. A mixture of Iarge-flowering single varieties providing a splendid assortment of colors. Pkt. 10c.; 1/80z. 35c.; 1/40z. 60c.; 1/20z. \$1.00.

1070. Glamour. (Giants of California.) Honorable Mention, 1942 All-America Selections. A glorious giant ruffled flower of soft salmon-rose, veined with brown in the creamy throat. Strong plants which really bloom.

1000. Hollywood Star. (Hybrida.) Silver Medal 1939 All-America Selections. Five-pointed stars of rose-pink with creamy throats. Plants grow about 18 inches high. Distinct. Pkt. 15c;; $\frac{1}{16}$ Oz. 35c.; 1/80z. 60c.; 1/40z. $\$ 1.00$.

1071. Martha Washington. (Fancy Nana Compacta.) Large 3-inch ruffled flowers of blush-pink, the center veined with wine-red deepening to violet. Dwarf, compact plants less than a foot high. Pkt. 25c.

1040. Pink Gem. (Dwarf Miniature) Six-inch plants with 2-inch flowers of deep pink. Pkt. 10c.; $\frac{1}{16} \mathrm{Oz} .45 \mathrm{c}$.

889. Purple Prince. (Grandiflora.) Large, plain-edged flowers of clear purple-violet. Pkt. 20c; $\frac{1}{16} \mathrm{Oz} .60 \mathrm{c}$; $1 / 80 z$. $\$ 1.00$.

1038. Rose Gem. (Dwarf Miniature.) Six-inch plants with bright rose flowers. Pkt. $15 \mathrm{c}$.; $\frac{1}{16} \mathrm{Oz} .45 \mathrm{c}$; $1 / 8 \mathrm{oz}$. $75 \mathrm{c}$.

946. Rose of Heaven. (Hybrida Nana Compacta.) Brilliant rose flowers on 12 -inch plants. Pkt. 10c.; $1 / 8 \mathrm{oz}$. $35 \mathrm{c}$.; $1 / 4 \mathrm{oz} .60 \mathrm{c}$.

905. Rosy Morn. (Hybrida Nana Compacta.) Rose with white throats on 12 -inch plants. Pkt. 10c.; 1/8oz. 40c.

1042. Snow Queen. (Hybrida Nana Compacta.) Snowwhite flowers on 12 -inch plants. Pkt. $10 \mathrm{c}$; $1 / 8 \mathrm{oz}$. 50c.; $1 / 4$ oz. $90 \mathrm{c}$.

972. Topaz Rose. (Hybrida.) The 11/2-foot plants bloom freely with flowers of fiery rose, suffused with gold. Pkt. 15c.; $1 / 80 z$. $75 \mathrm{c}$.

906. Finest Bedding Varieties, Mixed. A flower-garden in itself. Pkt. 10c.; $1 / 80 \mathrm{oz} .35 \mathrm{c}$; $1 / 40 \mathrm{Oz}$. 65c.; $1 / 2 \mathrm{Oz}$. $\$ 1.25$.

\section{Phlox Drummondi}

A splendid garden annual with branching plants 12 to 18 inches tall, bearing large heads of colorful bloom a few weeks after sowing seed.

988. Gigantea, Art Shades. Strong 18-inch plants with large flowers $11 / 2$ inches across in a variety of artistic soft shades. A free bloomer. Pkt. 15c.; 1/80z. 60c.; 1/40z. $\$ 1.00$ 895. Grandiflora, Crimson.

896. Grandiflora, Rose.

897. Grandiflora, White.

Any of above Phlox, pkt. 10c.; 1/80z. 60c.; 1/40z. $\$ 1.10$ 898. Grandiflora, Mixed. All the Phlox colors for gay beds. Pkt. 10c.; 1/80z. 50c.; $1 / 40 z$. 85 c.

\section{Poppies A., P.}

Lovely, distinct flowers deserving wide planting in every garden. The crinkly, silky texture of the petals appeals to everyone. They are hardy and the annual varieties should be sown in late fall or very early spring. For cut-flowers cut in bud and burn the stem ends. Better let Poppies stay where seed is sown. They are difficult to transplant.

\section{ANNUAL VARIETIES}

841. Sweet Briar. A double Shirley with flowers of wildrose-pink. Beautiful and different Poppy.

1058. Wild-Rose-Pink. Lovely Shirley with single flowers of true wild-rose-pink.

Any of the above Poppies, pkt. 10c.; 1/40z. 25c.; 1/20z. 45c. 1045. Shirley, Mixed. A fine mixture of this grand Poppy. Pkt. 10c.; $1 / 2$ Oz. 25c.; oz. $40 \mathrm{c}$.

ALL PRICES ARE SUBJECT TO MARKET CHANGES 
1043. Iceland Poppy, Mixed (Papaver nudicaule). The dainty Icelands grow 15 to 18 inches tall and bloom all summer. The frne-cut grayish foliage is attractive and the papery flowers are beautiful. Pkt. 10c.; $1 / 8 \mathrm{oz}$. 20c.; $1 / 4$ oz. 35c.; $1 / 2$ oz. 65c.

1044. Oriental Poppies in Mixture. Plants grow 2 to 3 feet tali and bloom in June. Gay shades of red. Pkt. $10 \mathrm{c}$; $1 / 8 \mathrm{Oz} .35 \mathrm{c}$; $1 / 4 \mathrm{Oz} .65 \mathrm{c}$

\section{Portulaca A., R-G.}

A gay bedding plant growing only a few inches high and thriving in light sandy soil in full sun. Use for edgings, solid beds and rockeries.

1046. Double, Mixed. Pkt. $15 \mathrm{c} ; \frac{1}{16}$ oz. $50 \mathrm{c} ; 1 / 8 \mathrm{oz} .90 \mathrm{c}$.

908. Single, Mixed. Pkt. 15c.; $1 / 80 \mathrm{oz}$. 50c.; $1 / 4 \mathrm{Oz}$. 85c.

\section{Pyrethrum P.}

912. Roseum, Mixed (Cbrysantbemum coccineum). The Painted Daisies are Iong-stemmed, daisy-like flowers of various colors. A good cut-flower. Pkt. 10c.; 1/80z. 40c.; $1 / 40 \mathrm{c}, 70 \mathrm{c}$.

\section{Ricinus (Castor-Bean) A.}

913. Communis zanzibarensis. Large plants, 6 feet or more tall, with large foliage giving a tropical effect. Pkt. 10c.; oz. 25c.; 1/4lb. 75c.

\section{Salpiglossis (Painted Tongue) A.}

914. Mixed. An "easy" annual growing 2 feet tall with gay flowers shaped about like those of petunias. The spectacular flowers have a base of one color and are veined and marked by a contrasting color. Prefers fult $1 / 10 z .40 c$

\section{Salvia (Scarlet Sage) A.}

The scarlet flowers of these Salvias are the most striking in the late summer and autumn garden. There is nothing else to compare with them for blazing color.

915. Bonfire (Clara Bedman). Compact, bushy, 2-foot plants with flowers of brilliant scarlet. Pkt. 20c; 1/80z. $75 \mathrm{c} . ; 1 / 4 \mathrm{OZ}$. \$1.25.

1065. Farinacea, Blue Bedder. A., P. Plants $2 \frac{1}{2}$ feet high with beautiful blue flowers from July to October. A perennial but will bloom frrst year if planted in spring. Pkt. 15c.; 1/80z. 60c.; 1/40z. $\$ 1.00$.

916. Splendens. Taller plants to 3 feet with bright scarlet flowers. Pkt. 10c.; $1 / 8 \mathrm{oz}$. 45c.; $1 / 4 \mathrm{oz} .85 \mathrm{c}$; oz. $\$ 3.25$.

\section{Scabiosa (Mourning Bride) A., P.}

1049. Blue Moon. A. Fully double, beehive-shaped flowers of deep lavender-blue. Plants grow over 3 feet tall and provide quantities of long-stemmed flowers to cut. Pkt. 15c.; $1 / 4 \mathrm{Oz}$. 45c。; $1 / 2 \mathrm{Oz} .75 \mathrm{c}$

954. Rosette. A. A new large-flowering type with lovely "pin-c ıshions" of deep rose suffused salmon. A good bloomer. $31 / 2 \mathrm{ft}$. Pkt. 10c.; $1 / 8 \mathrm{Oz}$. 25c.; $1 / 4 \mathrm{Oz} .45 \mathrm{c}$.

917. Mixed Annual Varieties. Pkt. 10c.; 1/4oz. 20c.; $1 / 2$ oz. 35c.; oz. 60c.

1050. Caucasica perfecta. P. Perfectly hardy 3-foot plants with delightful fringed "Bluebonnets" of lavender. A fine cut-flower. Pkt. 15c; ; $\frac{1}{16}$ oz. 40c.; $1 / 80 z$. 60c.; 1/40z. \$1.00.

\section{Scarlet Runner Bean A.}

918. Phaseolus coccineus. A rapid-growing vine with sprays of brilliant red flowers formed like pea blossoms. Although stringy it is a good Snap Bean. The dry, ripe Beans are bright red. Pkt. $10 \mathrm{c}$.; oz. $15 \mathrm{c}$; $1 / 1 / 4 \mathrm{lb} .50 \mathrm{c}$.

Schizanthus (Butterfly Flower) A, R-G.

911. Pinnatus. Bushy $11 / 2$-foot plants with handsome butterfly-like blooms marked with contrasting colors. Blooms all summer. Pkt. 10c.; 1/40z. 35c

\section{Statice A.}

1066. Sinuata, Mixed. Cloud-like masses of colorful flowers. May be dried for winter use. Pkt. 10c.; $1 / 40 z$. $25 \mathrm{c} . ; 1 / 20 z$. $40 \mathrm{c}$.
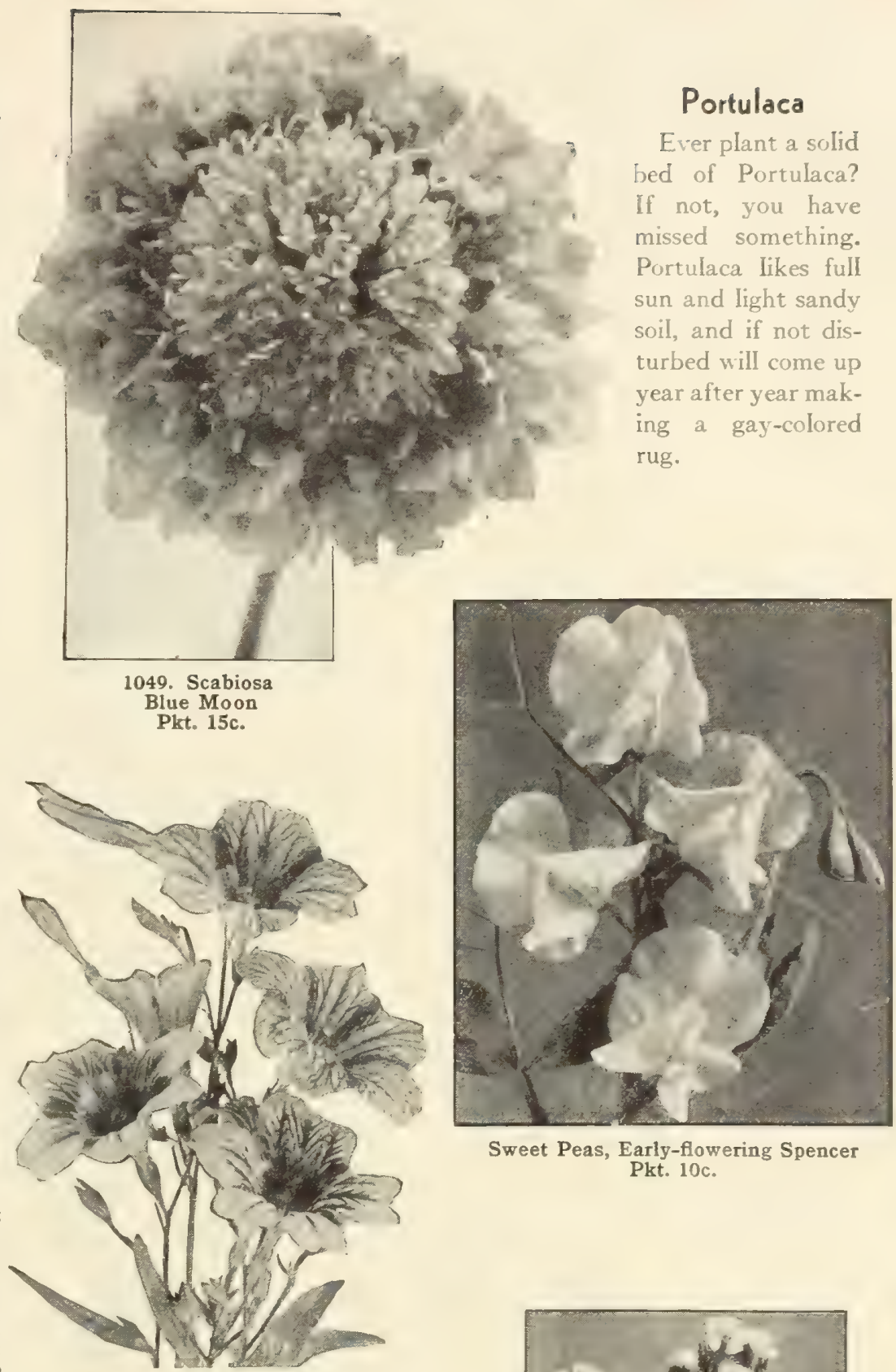

914. Salpiglossis, Mixed Pkt. 10c.

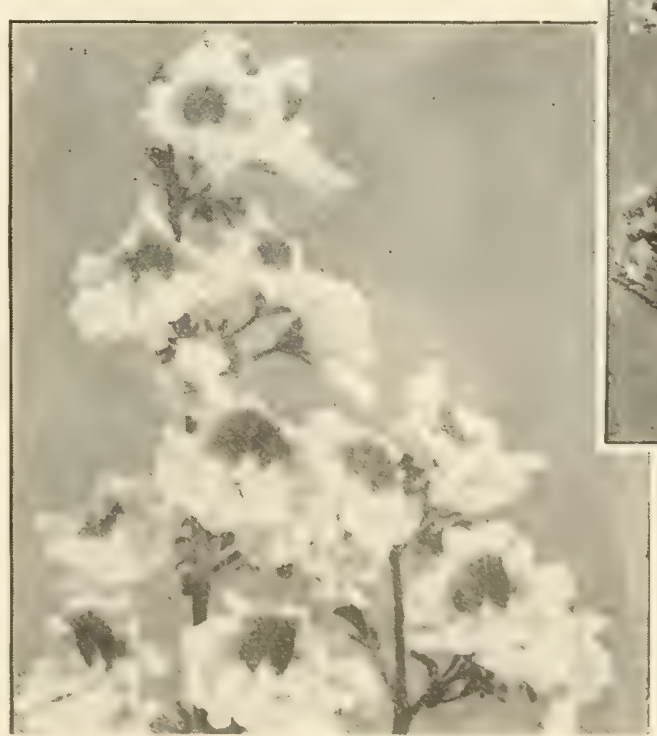

911. Schizanthus (Butterfly Flower) Pht. 10c. 


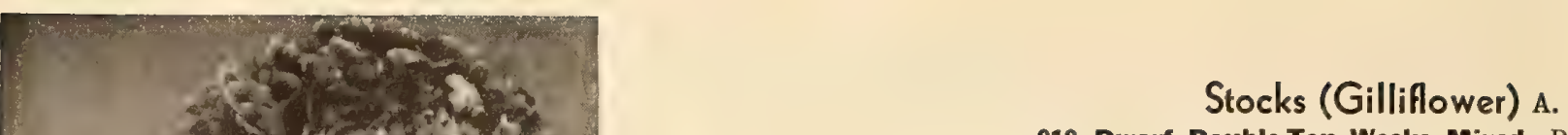

1045. Poppy, Shirley, Carnation-flowered, Mixed. Pkt. 10c

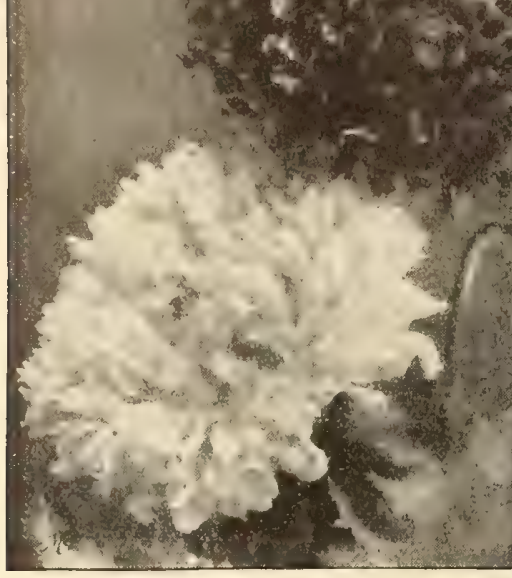

1065. Salvia farinacea, Blue Bedder Pkt. 15c. iोI $\rightarrow$
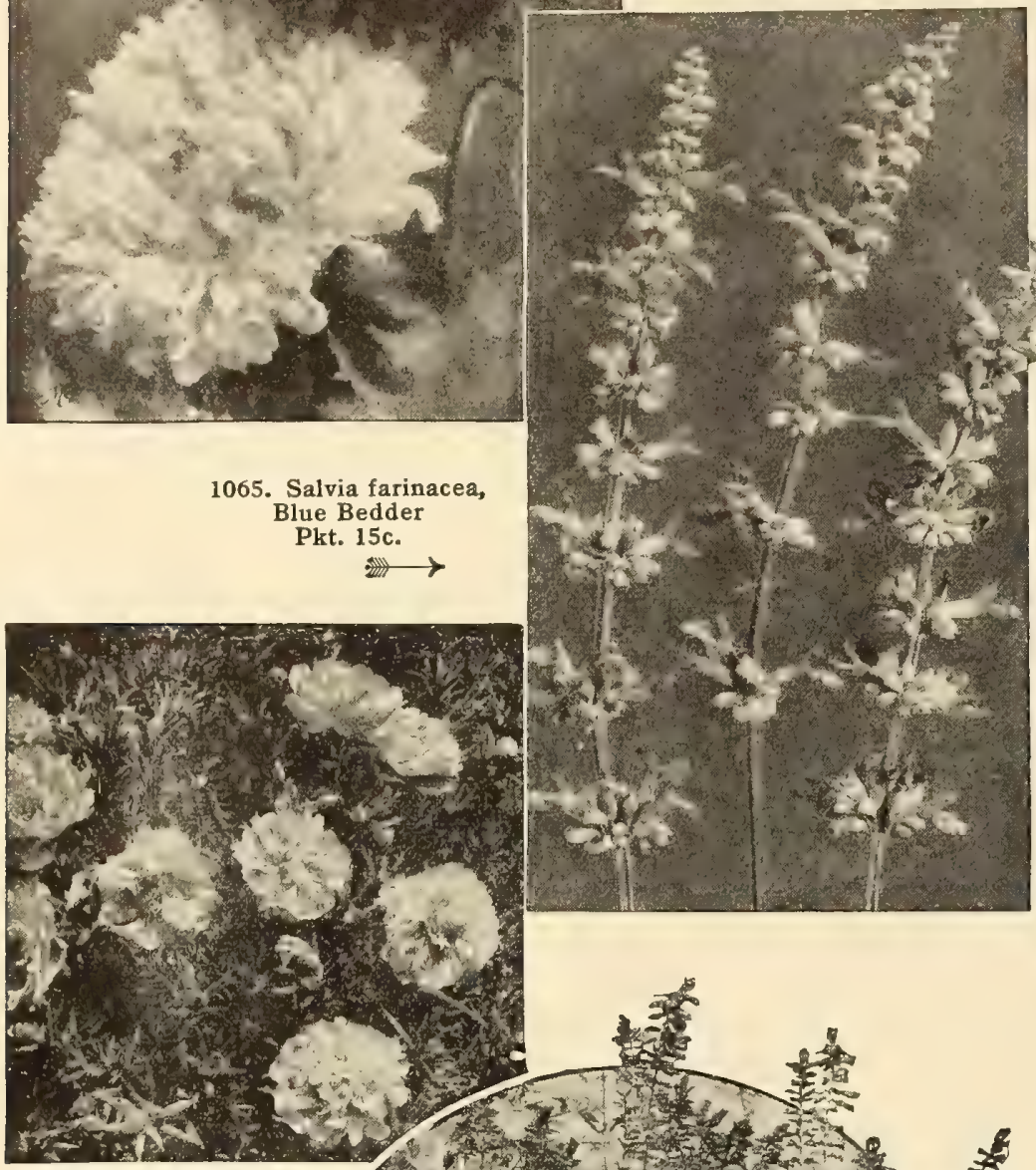

1046. Portulaca Double, Mixed Pkt. $15 \mathrm{c}$.

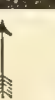
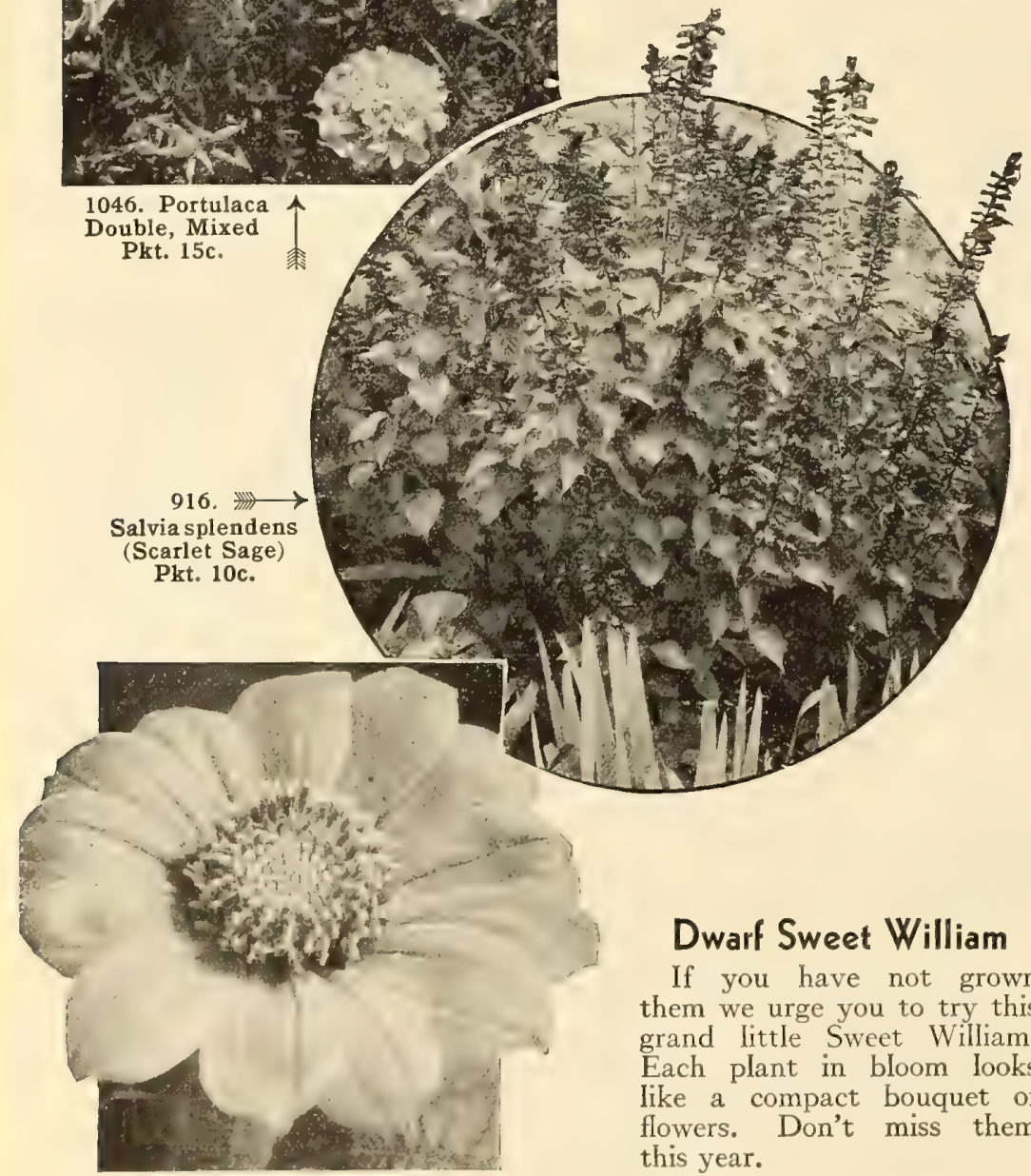

990. Tithonia speciosa Pkt. 10c. like a compact bouquet of flowers. Don't miss them this year.
919. Dwarf, Double Ten-Weeks, Mixed. Popular garden flower because of the frne spikes of bloom in interesting colors and their delightful fragrance. A great cut-flower. Plants 12 inches with flowers of white, yellow, pink and bue. Pkt. 5c.; 1/8oz. 25c.; $1 / 40 z$. 40c.; $1 / 2$ oz. $70 \mathrm{c}$.

\section{Stokesia (Stokes' Aster) P.}

1051. Cyanea. Large shaggy flowers of deep blue somewhat resembling a single Aster. Does best in light soil. Grows $1 \frac{1}{2}$ to 2 feet tall and blooms from July to frost. Pkt. 10c.; $1 / 80 z, 40 c$.

\section{Sunflower A.}

920. Chrysanthemum-flowering. Spectacular 4 to 5inch golden yellow double flowers that stand 4 feet high. 4

\section{Sweet Peas A.}

Everyone loves dainty fragrant Sweet Peas and every garden should have enough to supply the house with cutflowers during late spring and summer.

Culture. Sow as early in the spring as the ground can be worked in rich, well-limed soil with good drainage. Make a trench about 4 inches deep and sow the seed in the bottom of it, covering with about 1 inch of soil. plants attain a herght of fi cultivate them and gradually fill up the trench to the level of the ground. One ounce will plant a 15-foot row.

\section{EARLY-FLOWERING SPENCER VARIETIES}

Although these are especially grown for under-glass culture we find they are equally desirable for the garden.

955. Amethyst. Royal purple.

959. Exposition Pink. Rich pink.

961. Harmony. Lavender shaded rose.

960. Hope. Pure white.

958. Mrs. Hoover. Clear blue.

962. Red Bird. Crimson-red.

964. Shirley Temple. Soft rose-pink, fluted and frilled.

963. Valencia. Sunproof orange

Any of the above Early-flowering Spencer Sweet Peas, pkt. 10c.; $1 / 2$ oz. 30c.; oz. 50c.

969. Mixed Early Spencers. Pkt. 10c.; oz. 25c.; 1/4lb. $80 \mathrm{c}$; Ib. $\$ 2.50$

\section{LATE SPENCER OR ORCHID-FLOWERING VARIETIES}

The Iate Spencers produce more flowers and have longer stems than the early varieties.

966. Damask Rose. Bright rose-carmine.

977. Gleneagles. Large; lavender.

965. Huntsman. Bright scarlet.

967. Peggy Ann. Salmon-pink

999. Pierrot. White, blue edges.

968. Pinkie. Rose-pink; frilled.

971. Pirate Gold. Golden orange.

978. Reflection. Clear blue.

973. Royal Purple. Rich purple.

974. Sextet Queen. Pure white.

Any of the above Late Spencer or Orchid-flowering Sweet Peas, pkt. 10c.; oz. 25c.; 1/4lb. 80c.; lb. $\$ 2.50$

1002. Superb Mixed Spencers. Pkt. 5c.; oz. 15c.; $1 / 4 \mathrm{Ib}$ $50 \mathrm{c}$.; Ib. $\$ 1.75$

957. Bolgiano's Special Grandiflora Mixture. A super-

lative mixture of the old-fashioned sweet-scented Sweet

Peas. Pkt. 5c.; oz. 10c.; 1/4Ib. 35c.; Ib. \$1.25.

Sweet William (Dianthus barbatus) в., R-G.

An old-fashioned border plant which is usually treated as a biennial, growing new plants every year for the second year's bloom. Plants grow 1 to $11 / 2$ feet tall have large heads of bloom and are used for bedding, borders or the rock-garden.

922. Newport Pink. Salmon-pink. Single.

923. Scarlet Beauty. Deep scarlet. Single.

1052. White. Pure white. Single

Any of the above Sweet Williams, pkt. 10c.; 1/80z. 25c.; $1 / 4$ oz, $40 \mathrm{c}$.

924. Single, Mixed. Pkt. 10c.; 1/40z. 25c.; 1/20z. 40c.;

925. Double, Mixed. Pkt. 10c.; 1/8oz. 25c.; 1/40z. 40c.; $1 / 2$ oz. 75 c.; oz. $\$ 1.25$.

1039. Dwarf Double, Mixed. A new type only 9 inches high bearing large heads of single flowers in a wide range of attractive colors. An ideal edging plant or for spots here and there in the rock-garden. Pkt. 15c.; $1 / 40 \mathrm{z}, 50 \mathrm{c}$.

4

F. W. BOLGIANO \& CO., INC. 
Thunbergia (Black-eyed Susan) A.

927. Alata, Mixed. Rapid-growing vines with neat foliage bearing attractive white, yellow or orange flowers, each with a black "eye." Pkt. 10c.; $1 / 4 \mathrm{oz}$. 35c; $1 / 2 \mathrm{Oz}$. 60c.

\section{Tithonia A.}

990. Speciosa (Mexican Sunflower). Tall plants 8 to 10 feet high bearing orange-scarlet single flowers about 4 inches across. Seed started indoors in March and transplanted when ground gets warm should bloom in ate August. Pkt. $10 \mathrm{c}$; $1 / 8 \mathrm{Oz} .30 \mathrm{c}$; $1 / 4 \mathrm{Oz}$. 50c

\section{Tritoma (Red-Hot Poker) P.}

928. Hybrida. Seed started indoors from January to March and planted out in April should bloom the first year. Striking red spires of bloom

\section{Venidium A.}

1047. Fastuosum (Monarch of the Veldt). A South African plant 2 to 3 feet tall bearing golden orange daisies with reddish brown centers. Flowers are 3 to 4 inches in diameter. Should be planted in fu!l sun. Pkt. 15c.; $\frac{1}{16}$ Oz. $40 \mathrm{c}$; $11 / 8 \mathrm{Oz} .75 \mathrm{c}$

\section{Verbena A., R-G.}

Spreading plants, each branch tipped with a large dome-like head of small flowers. A splendid bed or border annual.

938. Floradale Beauty A giant type with large heads of flowers ranging from bright rose-pink to deep rose-red.

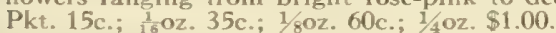

929. Fine Mixed. Includes rose, scarlet, violet, yellow and white varieties. Pkt. 10c.; $1 / 4 \mathrm{oz}$. 40c.; $1 / 2 \mathrm{Oz}$. 65c.

\section{Vinca A.}

930. Rosea, Mixed (Periwinkle). Foot-high plants with shiny dark foliage and neat pink and white flowers. slowly. A fine pot-plant as well as a bedder. Pkt. 10c.; $1 / 8$ oz. 25c.; 1/40z. 40c.; 1/20z. $75 \mathrm{c}$

\section{Viola P., R-G.}

1054. Cornuta, Mixed (Tufted Pansy), A dependable Viola growing about 6 inches high and bearing its lovely flowers, which resemble but are smaller than pansies, in quantity over a long period. The mixture includes yellow, blue, lavender and white varieties. Pkt. $15 \mathrm{c}$. $1 / 8$ oz. 50 c.

\section{Wallflower P., R-G.}

931. Finest Single, Mixed. Plants are only half-hardy and should be protected over winter by moving to a coldrame and bringing back in spring. They have a $1 / 40 z .50 \mathrm{c}$.

933. Wild Flower Garden Mixture. A. This is a mixture of California native hardy annuals suitable for planting in odd corners or on a vacant lot. They are easily-grown varieties and will be found very desirable for cutting. Pkt. 10c.; $1 / 2$ oz. 25c; oz. 40c.; 1/4l Ib. $\$ 1.25$

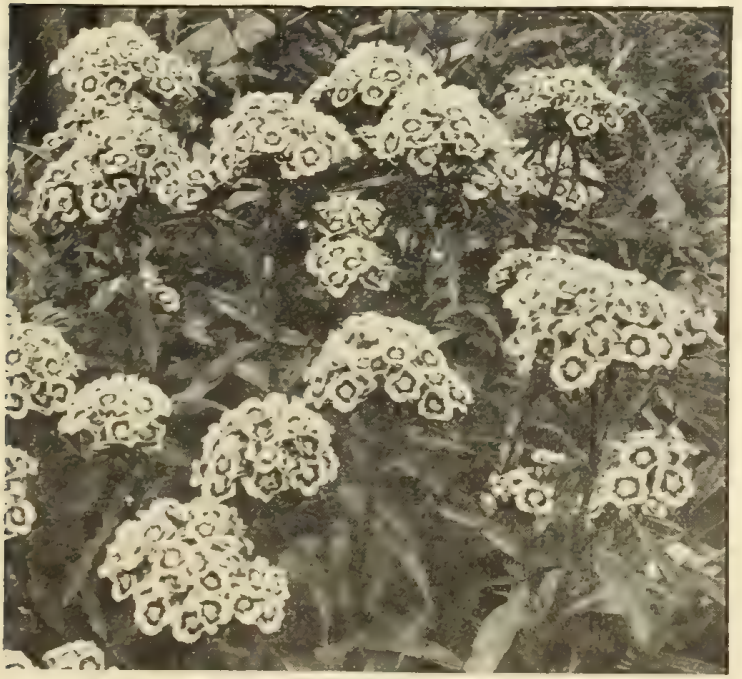

924. Sweet William, Single, Mixed. Pkt. 10c.

WASHINGTON, D. C.
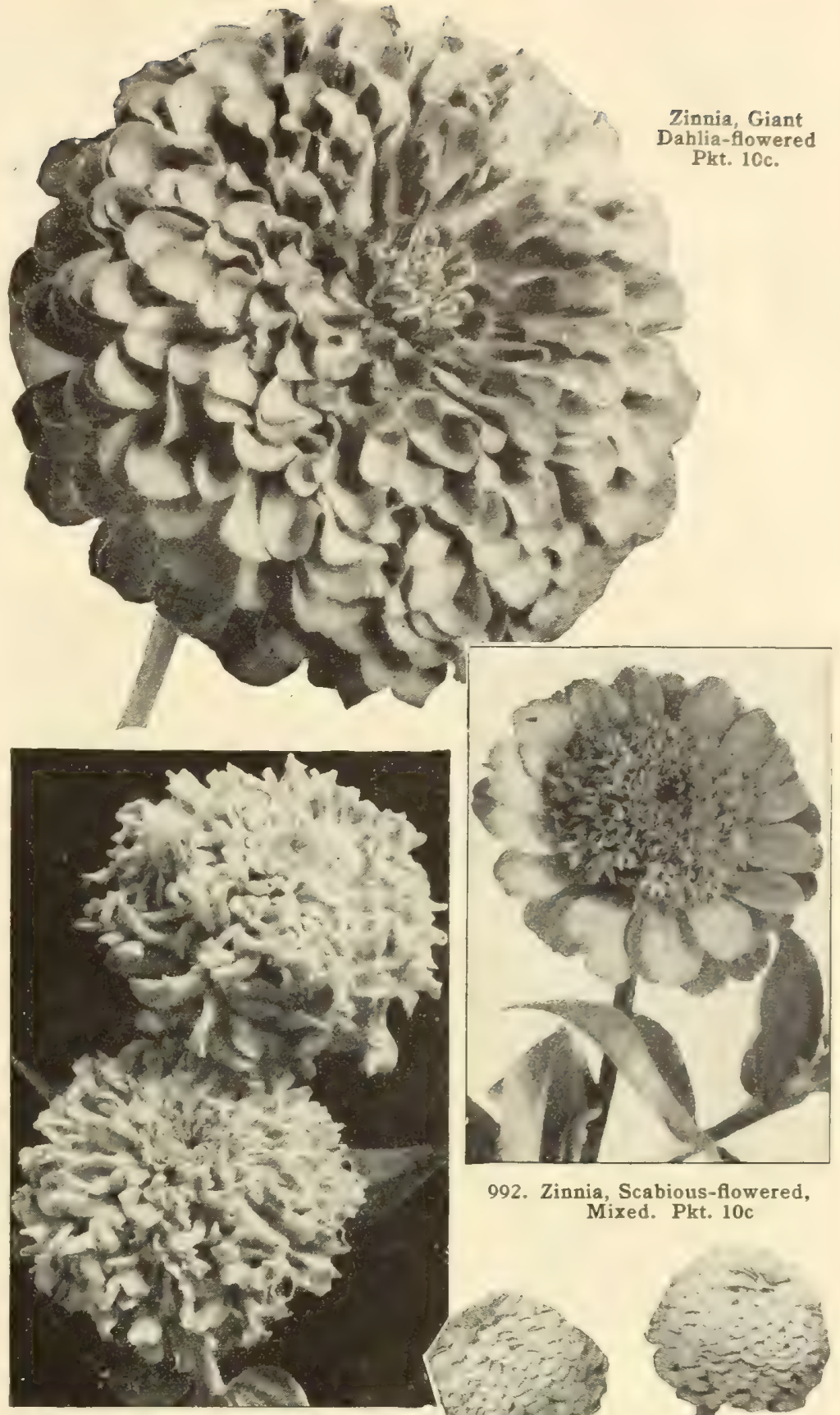

982. Zinnia, Fantasy, Wildfire Pkt. 15c.

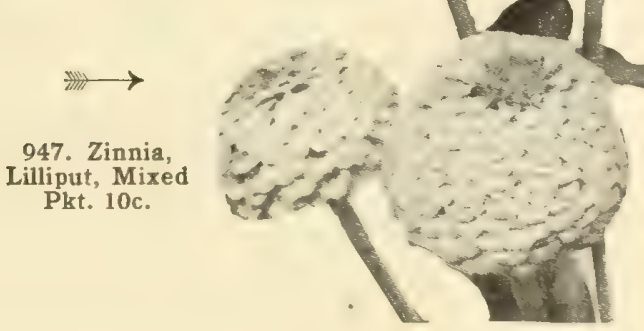

Satisfaction from Annuals

Most gardeners grow the same things year after year and never know the pleasure of venturing into new experiences.

Look through our list of annuals this year and try some of the things you have never grown before. A few may disappoint but many will so please that you will never want to be without them again. Expand your garden experience. 


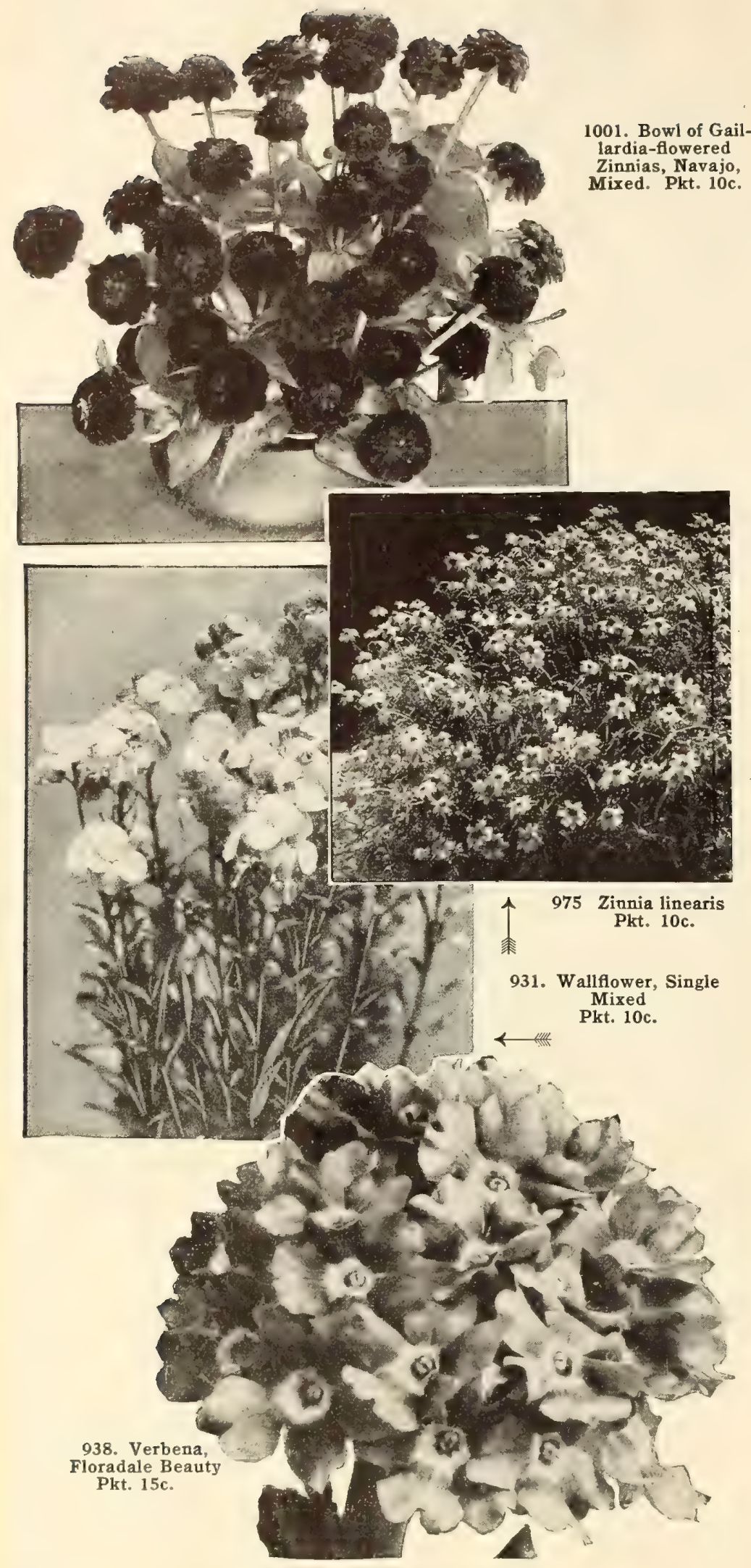

Zinnias (Youth-and-Old-Age) A.

One of the most showy and satisfactory annuals for every garden. There is a wide range of types and hues to provide color for the garden and generous quantities of cut-flowers from early summer until frost. They are easy to grow in any good garden soil.

\section{CALIFORNIA GIANTS}

These are the tallest Zinnias, growing 3 to 4 feet tall, with very large double flag flowers on long stems. A splendid cutting type.

935. Enchantress. Light rose, deep rose center.

936. Goiden Queen. Golden yellow.

937. Purity. Best white in Zinnias.

934. Scarlet Gem. Glowing scarlet.

Any of the above California Giant Zinnias, pkt. 10c.; $1 / 4$ oz. 35c.; 1/20z. 60c.; oz. $\$ 1.00$.

1057. Mixed. A fine mixture. Pkt. 10c.; $1 / 40 z .25 c$.; $1 / 20 z$. $40 \mathrm{c}$; oz. $75 \mathrm{c}$.

\section{DAHLIA-FLOWERED VARIETIES}

Robust plants, 21/2 to 3 feet tall, bear many strong stems of fully double, 4 to 5 -inch flowers resembling the show type of dahlia. Popular for bedding and to cut.

940. Canary Bird. Primrose-yellow.

939. Exquisite. Light rose, deep rose center.

941. Oriole. Orange and gold bicolor.

943. Polar Bear. Pure white

942. Purple Prince. Deep purple.

944. Scarlet Flame. Bright scarlet

Any of the above Dahlia-flowered Zinnias, pkt. b0c.; $1 / 4$ oz. 35c.; $1 / 2$ oz. 60c.; oz. $\$ 1.00$

945. Mixed. All the Dahlia-flowered colors. Pkt. 10c.; $1 / 4$ oz. 25c.; $1 / 2$ oz. 40c.; oz. $75 \mathrm{c}$.

\section{FANTASY VARIETIES}

Plants 2 to $2 \frac{1}{2}$ feet high with 3 -inch shaggy flowers something like cactus dahlias. Distinctly different from all other Zinnias, they bring novelty to the garden and come into bloom 6 to 7 weeks from time of sowing seed.

956. Star Dust. Rich deep golden yellow. Pkt. 10c.; 1/8oz.

982. Wildfire. Dazzling scarlet. Pkt. $15 \mathrm{c}$; $1 / 8 \mathrm{oz} .25 \mathrm{c}$; $1 / 40 \mathrm{oz}$. 40c.

983. Finest Mixed. A wonderful mixture including shades of red, orange, and yellow. A bed of these is really astonishing. Pkt. 10c.; 1/80z. 20c.; $1 / 40 \mathrm{oz}$. 35c.; $1 / 20 \mathrm{z} .60 \mathrm{c}$.

\section{GAILLARDIA-FLOWERED NAVAJO}

1001. Finest Mixed. The 2 -inch flowers resemble a double annual gaillardia. Plants grow about 2 feet tall and bloom in about 45 days from seed. Colors range through the soft tones of rose, pink, bronze, yellow, orange and lavender. Pkt. 10c.; $1 / 4 \mathrm{Oz}$. 40c.; $1 / 2 \mathrm{oz}$. 75c.

\section{LILLIPUT OR POMPON VARIETIES}

These are the most popular of the Zinnia family for cutting and they make attractive solid beds. Plants grow $11 / 2$ to 2 feet tall and are free with their colorful little pompons on good vase-length stems.

847. Canary Gem. Canary-yellow.

998. Crimson Gem. Rich crimson.

848. Lilac Gem. Clear Iilac.

970. Pink Gem. Deep pink.

996. Salmon Gem. Salmon-rose.

802. White Gem. Pure white.

Any of the above Lilliput or Pompon Zinnias, pkt. $10 \mathrm{c}$. $1 / 40 \mathrm{z}$. 35c.; $1 / 2 \mathrm{oz}$. $60 \mathrm{c}$

947. Mixed. All the above and others. Pkt. 10c.; 1/4oz. 25 c.; $1 / 2$ oz. 40 c.; oz. $75 \mathrm{c}$

\section{SCABIOUS-FLOWERED VARIETY}

992. Mixed. The flowers of these resemble in form both the annual scabiosa and Harmony marigolds. They have a collar of fairly wide petals surrounding a tufted center. Plants grow about $21 / 2$ feet tall, so that there are good stems for cutting. Colors run through crimson, scarlet, pink, orange, and yellow. Pkt. 10c.; 1/80z. 25c.; $1 / 4$ oz. $40 \mathrm{c} ; 1 / 20 \mathrm{oz} .75 \mathrm{c}$

\section{DWARF ZINNIA}

\section{Zinnias}

With so many types to choose from, the Zinnia family stands high among annuals.

They are all fine cut-flower material and in solid beds one can have real spectacles.

The little Linearis is a fine front border plant and one never has enough of the dainty Lilliputs and Pompons.

975. Linearis. A dwarf native of Mexico growing 8 to 10 inches tall, the bushy little plants covering themselves with lovely single flowers of golden orange with a lemonyellow stripe through each petal. A splendid edging plant. Flowers in 6 weeks from seed. Pkt. 10c.; 1/8oz. 35c.; $1 / 40 z$. 65c.

ALL PRICES ARE SUBJECT TO MARKET CHANGES 


\title{
Bolgiano's Roses
}

SIX BEAUTIFUL ROSES FOR 1943 Strong 2-Year-Old Field-Grown Plants

\author{
See illustration in color on back cover
}

SPECIAL OFFER - One each of these 6 for \$4.25, postpaid.

Condesa de Sastago. Spectacular fragrant flowers of burning copper with a yellow reverse. Each $80 \mathrm{c}$.

Editor McFarland. Long-lasting, perfectly formed blooms of deep pink on fone stems. SIightly fragrant. Each $80 \mathrm{c}$.
Etoile de Hollande. The world's favorite red Rose. Large shapely flowers of rich Mrs. Pierre S. du Pont. Beautiful flowers of rich deep yellow appear in profusion on low healthy plants. Spicy fragrance. Each $80 \mathrm{c}$.
In this collection we offer six choice modern everblooming Roses which will please the most particular Rose-lover. They all have strong, healthy plants and will produce a great quantity of lovely fragrant blooms in the most popular Rose colors.

Mrs. Sam McGredy. Flowers a glorious blend of scarlet and orange and the plants have red canes and thorns and bronzy foliage. Fragrant. Each $80 \mathrm{c}$

Sir Henry Segrave. Large blooms of light lemon-yellow. Pleasing lemon fragrance. Each 80c.

\section{Standard Everblooming Hybrid Tea and Climbing Roses}

Good Strong Two-Year-Old Dormant Plants each 70c.; 10, \$6.50. Add 10 per cent for Express or Parcel Post Orders.

Ami Quinard. Velvety crimson-maroon with soft black luster. Does not fade. The petals become darker as the bloom ages. Very fragrant.

Betty Uprichard. Copper-red buds, open orange-carmine. Verbena fragrance.

Caledonia. Large, long-pointed white buds and very fragrant white flowers of fine form.

Charles K. Douglas. Bright crimsonscarlet. Always dependable.

Christopher Stone. Scarlet-crimson. Lovely long-pointed buds borne singly on frrm stems open to vivid scarlet blooms. In the fall the color is of a blackish crimson. Plants are vigorous-growing, diseaseresistant, and flower profusely until frost. Very fragrant.

Director Rubio. Large blooms of a beautiful cochineal-pink which are held erect on rigid stems. Fragrant.

Duchess of Wellington. Enormous tapering buds of golden orange, slowly opening to very large saffron-colored, fragrant blooms.

Duquesa de Penaranda. The pointed buds are a blend of apricot-orange with dark pink opening to delightfully fragrant blooms of coppery apricot.

Faience. Large flowers of peach and yellow. Outer petals are of Iighter shade deepening toward the center. Strong upright grower.

Frau Karl Druscnki. Beautiful, large, pure white. Strong growth.

Golden Dawn. Well-formed, sweet-scented, large, double, sunflower-yellow flowers. Spreading growth.
Grenoble. Scarlet-crimson. One of the most
vigorous-growing crimson Roses. Blooms vigorous-growing crimson R.

Joanna Hill. Deep creamy yellow. Fine

Kaiserin Auguste Viktoria. Soft pearly white, opening to a large very double white. Intensely fragrant.

Lady Ashtown. Splendidly formed flowers of shining pink. Fragrant.

Luna. Creamy white. Long, tapering, moonlight-yellow buds opening to soft creamy white, fragrant blooms.

Margaret McGredy. Orange-scarlet. One of the most satisfactory garden Roses in existence. Very strong grower. Always in bloom.

McGredy's Scarlet. Splendidly formed blooms of clear light red on frne plants.

Mevrouw G. A. van Rossem. Glowing apricot, overlaid yellow. Fragrant.

Mme. Butterfly. Pink and gold; exquisite buds. Fragrant.

Mrs. Erskine Pembroke Thom. Longpointed yellow buds; well-shaped blooms of clear canary-yellow. Strong growth.

President Herbert Hoover. A lovely blend of orange and pink. Fragrant. Tall growth.

Radiance. Brilliant rose-pink. Delicious fragrance. Foolproof plants.

Red Radiance. Deep rose-red. Fragrant. Sport of Radiance.

Rouge Mallerin. Brilliant deep red, opening to large flowers of glowing scarlet. Very fragrant.
Sœur Therese (Sister Therese). The long, tapering buds are chrome-yellow, sweetly scented and held on excellent cutting stems. Talisman. Gold, apricot-yellow, deep pink and old-rose. Fragrant.

\section{CLIMBING ROSES}

Each 70c.; 10, $\$ 6.50$

Dr. W. Van Fleet. Pale pink buds and Emily Gray. Beautiful pale orange-yellow. Long-pointed buds.

Cl. Kaiserin Auguste Viktoria. Pure white double blooms with light lemon center. Everblooming

Cl. Lady Ashtown. Everblooming. Pink. Mary Wallace. A sturdy grow

cl. President Herbert Hoover.

blend of orange and pink. Everblooming.

Paul's Scarlet. Clear vivid scarlet.

Prosperity. White flowers in great clusters. Repeat-blooming.

Silver Moon. Large creamy white flowers with brilliant yellow centers.

Cl. Talisman. Gold, apricot-yel

Zepherine Drouhin. Vivid pink. Blooms profusely in the spring and some in the fall. The plants have thornless canes and healthy foliage.

We recommend Membership in the American Rose Society to all Rose-lovers. Write Secretar
details.

\section{New Patented Everblooming Hybrid Tea and Climbing Roses}

Parcel Post or Express charges must be included with your remittance if delivery is to be made by Mail or Express. Weight each about 5 pounds. For Parcel Post rates, see page 2.

Countess Vandal. (PIant Patent No. 38.) Coppery bronze and pink suffused with gold. Each \$1.25, Fertil-Potted.

Crimson Glory: (Plant Patent No. 105.) Velvety blackish crimson. Delightfully fragrant. Each \$1.25, Fertil-Potted.

Eclipse. (Plant Patent No. 172.) Long tapering streamlined buds of the same golden yellow as the open bloom. Each $\$ 1.50$, Fertil-Potted.

Eternal Youth. (Plant Patent No. 332.) Soft pink livening to yellow at base of petals. Fragrant. Each \$1.50, FertilPotted.

Heart's Desire. (Plant Patent No. 501.) Dark red flowers of fine form and wonderful Fragrance. Strong. Each \$1.75, FertilPotted.
All Fertil-Potted. Available Until June 1 Mary Margaret McBride. (Plant Patent No. 537.) Nicely formed fragrant flowers of deep coral-pink with gold at
petals. Each $\$ 1.75$, Fertil-Potted.

Pearl S. Buck. (Plant Patent No. 423.) Pointed orange buds and deep yellow flowers with tinges of apricot. Fragrant. Each \$1.75, Fertil-Potted.

Pinocchio. (Plant Patent No. 484.) This is not a Hybrid Tea but is a Polyantha and is the frnest cluster Rose we have ever seen. Lovely salmon buds open the same color then change to soft pink. Delightful fragrance. A superb Rose for arrangements. Each \$1.50, Fertil-Potted.

Rex Anderson. (Plant Patent No. 335.) Large ivory-white blooms of fine form. Fragrant. Each \$1.75, Fertil-Potted.

Signora. (Plant Patent No. 201.) Graceful buds of warm brownish orange open mandarin and salmon. Each $\$ 1.25$, FertilPotted.

\section{CLIMBERS}

Blaze. (Plant Patent No. 10). The everblooming Paul's Scarlet Climber. Each $\$ 1.25$, Fertil-Potted.

Doubloons. Clusters of Iarge cup-formed blooms of saffron-yellow. Each \$1.25, Fertil-Potted.

Dr. J. H. Nicolas. (Plant Patent 457.) An everblooming Pillar Rose with fully double fragrant rose-pink flowers. Each \$1.75, Fertil-Potted.

June Morn. (Plant Patent No. 375.) Double flowers of watermelon-pink with a golden reverse on an 8-foot Pillar Rose. Each $\$ 1.75$, Fertil-Potted

King Midas. (Plant Patent applied for. Large yellow flowers in clusters of 4 to 6 on
strong climbing plants. Each $\$ 1.75$. strong climbi
Fertil-potted.

New Dawn. (Plant Patent No. everblooming Dr. W. Van Fleet. Fragra
pink flowers on long stems. Each $\$ 1.75$. Fertil-Potted. 


\section{Hardy Perennial and Biennial Flower Plants}

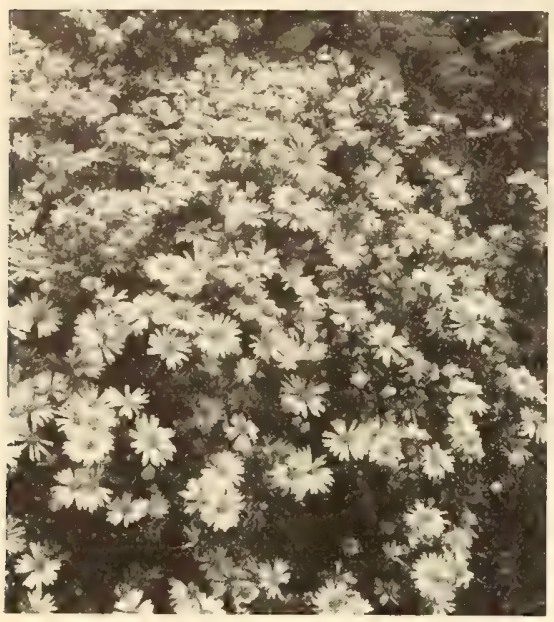

Dwarf Aster

POSTAGE ON PLANTS:

Add for postage and packing: Single plants $10 \mathrm{c}$. $; 3$ plants $20 \mathrm{c}$. $; 6$ plants $30 \mathrm{c}$. 12 plants $40 \mathrm{c}$. We can supply many other varieties of plants than those listed. Orders promptly filled.

Culture: A deep well-drained bed of enriched soil is essential to the proper growth of the plants. Care taken in providing a suitable bed will repay you many times as you watch the succession of various beautiful, fragrant blooms through the seasons, year after year. They should be planted in March or April, according to the season, for best results.

\section{Alyssum (Madwort)}

Perennial Alyssums furnish masses of color in early spring and, being low-growing, are ideal for rock-gardens, wall-gardens and the front of borders.

Saxatile compactum. Broad masses of bright yellow flowers in early spring.

\section{Aquilegia (Columbine)}

One of the most valuable of the earlyflowering perennials. The long-spurred blooms and lengthy stems are well adapted to use as cut-flowers, but they also produce a beautiful effect when massed in the garden. They do best in light soil in a sheltered Iocation that gets the sunshine. 1 to $2 \mathrm{ft}$. May, June.

Chrysantha (GoIden, Columbine). YeIlow flowers with long spurs.

Crimson Star. Large flowers with rich crimson outer petals and pure white centers.

Mrs. Scott Elliott's Long-spurred Hybrid Strain. Pastel shades. Rose Queen. Pink; long-spurred.

\section{Anemone japonica}

The fall-blooming Windflowers are easyto-grow, long-lived plants providing beautiful bloom during September and October. They do well in light shade and should be watered during dry periods.

Alice. Large semi-double flowers of $\mathrm{La}$ France-pink. A good cut-flower. $3 \mathrm{ft}$. Whirlwind. Similar to above, but pure white, 2 to $3 \mathrm{ft}$.

Prices: Unless otherwise priced, all plants are sold at, each $30 \mathrm{c}$; 3 of any one variety $75 \mathrm{c}$; 6 of any one variety at dozen rate; doz. $\$ 2.50$.

Anemone Pulsatilla

(Pasque Flower)

Large violet-blue flowers in early spring. 10 to 12 inch.

\section{Asters \\ (Michaelmas Daisies)}

These splendid autumn bloomers are the life of September and October gardens. The big bushy plants grow 3 to 5 feet tall with as much spread and cover themselves with lovely Daisies for garden show and to cut. The display lasts for weeks. Plant in full sun.

Barr's Pink. Deep pink flowers with showy gold and bronze centers.

Beechwood Challenger. Glowing crimson. Splendid new red Aster with great promise. $3 \mathrm{ft}$.

Blue Eyes. Large pure violet-blue flowers with small yellow eyes.

Blue Plume. Stately plants with fine spikes covered with deep purple almost double flowers. Showy variety. $2 \mathrm{ft}$.

Frikarti, Wonder of Staefa. A splendid hardy Aster with Iarge Iavender-blue flowers on 12 to 18 -inch stems. Blooms over a long period. 2 to $2 \frac{1}{2} \mathrm{ft}$. Each $40 \mathrm{c}$; $3, \$ 1.00$.

Harrington's Pink. Large flowers of clear soft pink. A beautiful Aster. $4 \mathrm{ft}$. Each 40c.; 3, \$1.00.

Hybridus luteus. Lovely small bright yellow flowers in clusters on 18 to 24 -inch stems. Blooms July to August.

Mt. Everest. Bushy plants covered with beautiful white flowers. $4 \mathrm{ft}$.

Ryecroft Purple. Large rich purple flowers on 5 to 6 -foot stems.

Skylands Queen. Violet-blue flowers with yellow centers.

\section{NEW DWARF ASTERS}

The low-growing Asters are mostly faIl bloomers and provide the same type of flowers as their tall relatives. As the plants are mound-like, and usually less than a foot tall, they find a place in the front of the border, or to spot in the rock-garden, and they make lovely solid beds. Give full sun in ordinary soil.

Acris nanus. Compact bushes with Iavender-blue flowers. Late August and September. 12 in.

Alpellus, Triumph. Sparkling blue daisies during June and July on a fine hardy plant. 8 in. Each 50c.; 3, \$1.25. Amellus, King George. Wide bushes 18 inches high covered with large blue flowers from July to September.

Mauve Cushion. Pale mauve-colored flowers during October. 6 to 8 in.

Snowsprite. Semi-double white flowers. 10 in. September.

Wartburg Star. Lavender-blue flowers in May and June. 12 to $15 \mathrm{in}$.

\section{Coreopsis (Tickseed)}

Everyman's golden flower. It will grow anywhere in any kind of soil and bears long-stemmed flowers which are valued for cutting. They bloom all summer.

Golden Giant. New. Extra-large yellow flowers.

Goiden Shower. The $11 / 2$-inch star-like golden flowers come in profusion from June to frost. $2 \mathrm{ft}$. Each $40 \mathrm{c} ; 3, \$ 1.00$.
Convallaria majalis

(Lily-of-the-Valley)

Low-growing plants with attractive foliage and nodding racemes of exquisite fragrant little bells from March to May. Plant in shade, using "woodsy" soil. Doz. $\$ 1.50 ; 100, \$ 10.00$.

\section{Chrysanthemums}

Beginning with the Cushion types in Iate August or very early September, Chrysanthemums are the glory of autumn gardens and last until heavy frosts blacken their lovely flowers. The finest of cutflowers, they provide a wide range of color and spicy fragrance loved by most everyone. Plant in full sun in rich soil and do not let the plants dry out.

\section{Single-flowering Varieties}

Astrid. Shell-pink, warmed with old-rose tints and a bright yellow center.

Fortuna. Vigorous plant covered with novel curly-petaled oxblood-red flowers.

Niobe. A dwarf, compact plant producing large flowers of glistening white with yellow dises.

Rosamund. Large duplex flowers of pale violet-rose - very attractive color.

Sensation. Very showy yellow flowers with every petal tipped scarlet.

Vesta. The large, almost duplex flowers are of a deep golden orange shade.

\section{Large-Type Varieties}

Aglow. Double variety with deep bright orange flowers.

Caliph. Oxblood-red, with rich velvety sheen or glow.

Lavender Lady. The double flowers are a lovely true lavender.

Pale Moon. Fluffy, loosely double flowers of pale sulphur-yellow.

Pohotcong. Lovely, double, deep pink flowers. Dark green foliage.

Seminole. Fluffy, double, creamy white flowers.

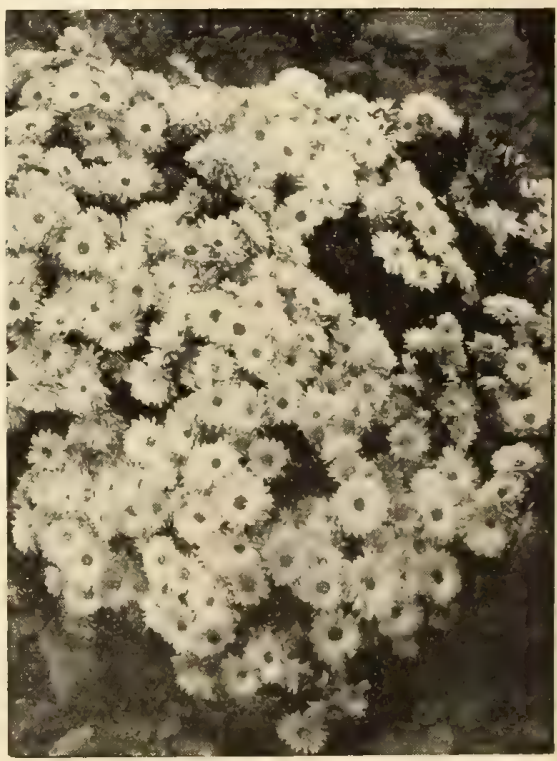

Chrysanthemum, Pink Cushion 
Prices: Unless otherwise priced, all plants are sold at, each $30 \mathrm{c}$.; 3 of any one varieiy $75 \mathrm{c}$; 6 of any one variety at dozen rate; doz. $\$ 2.50$.

\section{Button Chrysanthemums}

Early Bronze. Very small bronze flowers. Irene, A fine white. Splendid for cutting. Jewel. Very popular pink. Long cutting

Treasure Trove. Clear yellow. Begins to bloom in September.

\section{Pompon Varieties}

Capt. R. H. Cook. Rose petals tipped golden bronze.

Goblin. Warm bronze, shading to sparkling gold in open flower.

Judith Anderson. Small, well-rounded flowers of buttercup-yellow.

Mrs. H. Harrison. Large clusters of double pink flowers.

Ouray. Rich bronze flowers with coppery glow.

White Doty. A very fine white.

\section{Cushion Varieties}

These are descendants of Amelia (Azaleamum). The plants grow about 10 to 12 inches high and spread approximately 2 feet. They bloom quite early and are literally covered with bloom until frost.

Bronze Cushion. Deep bronze turning to coppery yellow.

Champion Cushion. Reddish bronze.

Pink Cushion. Light pink. An old favorite.

White Cushion. Opens a delicate pink turning to pure white.

Yellow Cushion. Pure golden yellow; very brilliant.

\section{Daisy (Shasta)}

The Shasta Daisies are popular, longlasting cutting flowers which do well in ordinary soil. Planted in masses they are attractive in the garden all summer.

Double White Swan. Masses of double white flowers on slender stems.

Mrs. C. L. Bell. An improved variety. Large flowers and Iong blooming season.

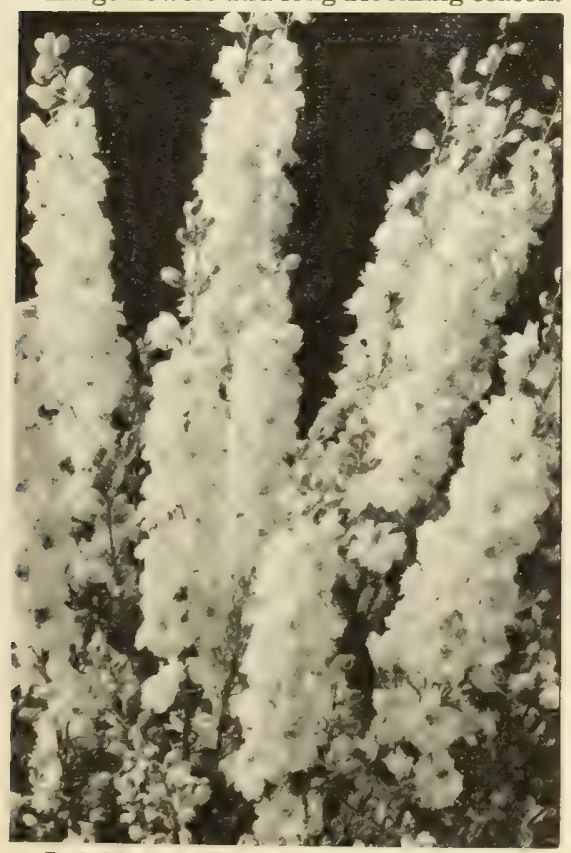

Delphinium, New Giant Pacific Hybrids

\section{Delphinium}

(Perennial Larkspur)

We offer three distinct types of this popular flower: The hybrids provide the long spikes of beautiful bloom so popular for exhibition purposes; cut down after the frist bloom, they will repeat in autumn. The Belladonna type is desirable to cut for mixed bouquets and blooms all season with the dwarf Chinensis providing desirable blue for bedding and cutting material all season. Delphiniums require rich soil in full sun.

Chinensis, Tom Thumb. A very pretty

variety with feathery foliage. On account of its dwarfness and brilliant blue flowers it is a popular plant for bedding and cut-flowers.

New Giant Pacific Hybrids. This is an outstanding new strain with many shades of huge florets beautifully spaced on strong spikes. Mildew-resistant. The best Delphinium plants in existence. Each 50c.; 3, \$1.25.

New Giant Pacific, Pure White. Long spikes of pure white flowers in this fine strain. Each 50c.; 3, \$1.25.

Belladonna. Light blue.

Bellamosum. Dark blue.

\section{Dianthus barbatus (Sweet William)}

Another old-time favorite which, being easy to grow, should be in quantity in every garden. The plants are from 12 to 18 inches tall and provide masses of color toward the front of the borders. Any good garden soil suits them. Blooms in May and June.

Newport Pink. SaImon-pink.

Scarlet Beauty. Bright scarlet.

White Beauty. White.

Mixed Hybrids. Many shades.

\section{Dicentra (Bleeding-Heart)}

Shade-loving plants with flowers of unquestioned charm. Spectabilis is the Bleeding-Heart of old-time gardens and should be in every garden with a shady spot. Eximia is a low-growing native fitting in here and there and provides attractive ferny foliage when not in bloom. Makes a good ground-cover.

Eximia. Fern-Iike foliage and pink heartshaped flowers all season. Partial shade or full sun.

Spectabilis. Graceful pink, heart-shaped flowers on Iong slender stems in April and May. Plants, each 35c.; 3, 90c.

\section{Eupatorium (Hardy Ageratum)}

Colestinum (Mist-Flower). One of the prettiest perennials. From August until November it is completely covered with dense heads of blue flowers similar to ageratum. Very good for cutting. 2 feet. Sun or light shade in ordinary soil.

NOTE: Be sure to include Postage and Packing Charges with your order. See top of page 44 .

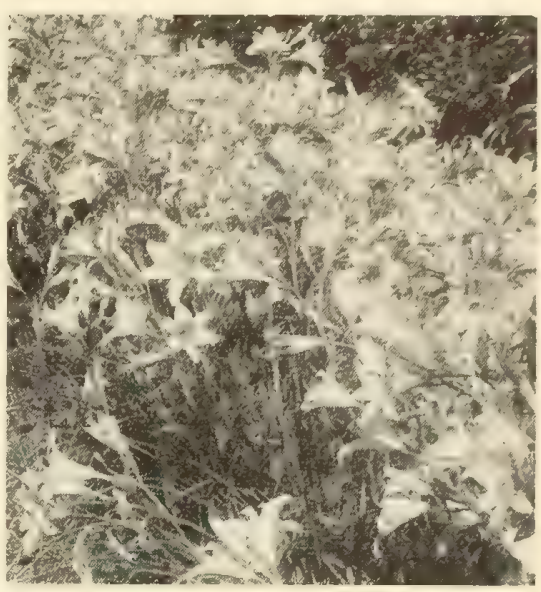

Hemerocallis (Day-Lily)

\section{Gaillardia (Blanket Flower)}

The Blanket Flowers are dependable border plants, furnishing gay color and lasting well for cutting. They thrive in ordinary garden soil in full sun and bloom all summer and fall.

Goblin. Grows 12 to 16 inches high and is covered with bright yellow flowers hav-

Mr. Sherbrook. A golden yellow variety with no other color. Large self-colored blooms on stout stems all summer.

Ruby. Vivid red flowers free from yellow

The Imp. Large bronze-crimson flowers. Each 35c.; 3, 90c.

New Giant Monarch Strain. Extralarge flowers in beautiful shades.

\section{Hemerocallis (Day-Lilies)}

Thriving almost anywhere, and not being bothered by either insects or disease, this is about as near a fool-proof garden plant as can be found. By planting our collection you can have bloom from May on, all through summer.

Dr. Regel. Rich orange-yellow flowers in May. Very fine for cutting.

Flava (Lemon Lily). Sweet-scented yelFlorham. Large golden yellow flowers.

George Yeld. Flushed petals, sprinkled rose; rich orange sepals. Each $\$ 1.00$; $3, \$ 2.50$

Hyperion. Large; canary-yellow. Each $\$ 1.00 ; 3, \$ 2.50$.

J. A. Crawford. Large; clear gold. Each 60 c.; $3, \$ 1.50$.

Kwanso. Large, double flowers of rich golden bronze shade.

Thunbergi. Much like Flava but flowers in July, a month later.

\section{Hosta (Funkia) (Plantain Lily)}

Another almost fool-proof plant. Its large rich green foliage is always attractive and the bloom, which appears during late summer, is very pleasing. Can be used anywhere and especially likes some shade.

Lancifolia. Long, narrow, green leaves with lilac-blue flowers. July and August.

Subcordata grandiflora (White August Lilv). Fine for shade. Each $40 \mathrm{c}$.

Undulata variegata. Bluc thowers. 


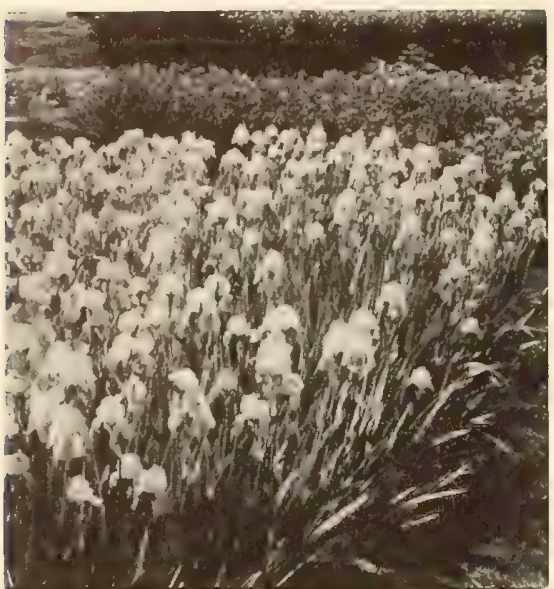

Bearded Iris (Flag Iris)

\section{Iberis (Hardy Candytuft)}

Delightful little evergreen plants that show up well wherever planted. Many are used in rock-gardens and they make splendid border plants, furnishing closely packed white bloom in spring.

Sempervirens. Six-inch plants cover themselves with white flowers in May. Does well in partial shade or full sun. A fine edging plant.

\section{Bearded Iris (Flas Iris)}

The Rainbow Flowers are popular everywhere and have so many admirers that there is a thriving Iris Society. Planted in the sun in ordinary good garden soil, they provide a wonderful display of gloriously colored flowers in May. A few varieties repeat in the fall. Every garden should have a collection.

Alta California. Tall; yellow.

Autumn King: Blue-purple bicolor. Autumn blooming.

Clara Noyes. Orange-red.

Dauntless. Red-purple.

Dolly Madison. Mauve and yellow.

Eleanor Roosevelt. Deep violet. Autumn blooming.

Frieda Mohr. Large; deep pink.

Jean Siret. Yellow; dwarf. Autumn blooming.

King Juba. Old-rose, edged carmine.

Laddie Boy. Deep purple.

Lieut. de Chavaignac. Brilliant violet. Dwarf. Autumn blooming.

Pink Satin. True pink self.

Pluie d'Or. Deep yellow.

Princess Beatrice. Light blue. Old favorite.

San Francisco. White, edged bue.

Sunlight. Soft yellow.

Talisman. Blend of red, yellow, pink and chamois.

William Mohr. Large violet blooms, veined gray.

\section{Iris sibirica (Sibirian Iris)}

Being smaller and more graceful these are greatly admired as cut-flowers. They are also easy to grow and bloom in May.

Perry's Blue. Clear blue. Stout stems. Snow Queen. A beautiful white. Very free flowering.

NOTE: Be sure to include Postage and Packing Charges with your order See top of page 44

\section{Iris pumila}

(Dwarf Iris or Miniature Flags)

A dwarf Iris that is ideal for the rockgarden. Blooms during March and April. Fairy. Pale blue.

La Fiance. White.

Orange Queen. Orange.

Prairie Gem. The 10 to 12 -inch plants bloom in both spring and fall. Beautiful yellow flowers.

Sambo. Deep blue.

\section{Iris Kaempferi (Oriental lris)}

These beautiful Iris prefer moist acid soil. An ideal place is around a pool or along the bank of a brook where their roots will not become dry. If planted in the border they should be kept well watered. If not acquainted with these Iris, the glorious flowers of the following varieties will surprise and please you. Bloom in June.

Blue Bird. Lovely blue flowers.

Cloud Dress. Double; white, veined mauve.

Dominator. Deep blue; single.

Doris Childs. White, rosy purple veins.

Gold Bound. Double; white, goldbanded center.

Helen Wells. Beautiful clear blue.

Mahogany. Mahogany-red; double.

Margaret Hendrickson. Blue-violet, white center.

Melpomene. Soft blue; double.

Pink Pearl. Pearly pink, lilac tone; double.

Purple and Gold. Violet-purple, golden throat; double.

Princess C. de Rohan. Dark purple.

Red Riding Hood. Single; red.

Rosa Anna. Ivory-white, with ruby veins.

Templeton. Reddish violet, mottled with white.

T. S. Ware, Iarge; violet-red, white center.

Victor. Light bue, blue veins.

Each $35 \mathrm{c}$.; 3 of any one variety $90 \mathrm{c}$. Assorted varieties, doz. $\$ 3.00$.

\section{Lupinus (Lupine)}

This fine perennial has closely set pealike flowers on spikes to 3 feet long, and a bed of Lupines in full bloom is a real picture. Plant in full sun and keep well watered. Blooms in May and June.

Polyphyllus. Pink, Blue, White, or Mixed.

Russell Hybrids. Beautiful pastel shades never before seen in Lupines. Each $35 \mathrm{c} ; 3,90 \mathrm{c}$.

\section{Matricaria (Feverfew)}

Low-growing plants with attractive double flowers all summer. They are good border plants and are dependable.

Little Gem. A dwarf variety with double white flowers from June on.

Golden Ball. Fine yellow form of the above.

PRICES: Unless otherwise priced, all plants are sold at, each 30c.; 3 of any one variety 75 c.; 6 of any one variety at dozen rate; doz. $\$ 2.50$

\section{Mertensia (Blue Bells)}

Virginica. One of the desirable spring natives found in shaded or partly shaded locations. It thrives in shady spots in a garden with ordinary soil. Looks best when planted in good-sized groups.

\section{Paeonia (Peony)}

A long-lived perennial, the plants growing larger and better year by year. They make a good showing in the garden and are favorite flowers for cutting. In planting the crown should never have over 2 inches of soil over it. If planted deep they will not bloom.

Baroness Schroeder. French white, changing to pure white.

Cherry Hill. Velvety garnet-red. Very early.

Elisa. Flesh-pink, shaded salmon.

Karl Rosenfield. The supreme red.

La Lorraine. Large; creamy white.

Marie Crousse. Soft salmon-pink.

Mons. Jules Elie. Large; pink. Early.

Nanette. White, golden stamens.

Primevere. Nearest to yellow.

Richard Carvel. Early. Cherry-red.

Sarah Bernhardt. Deep pink. Perfect cut-flower.

Therese. Marvelous soft pink.

Walter Faxon. Coral-pink.

Each 75c.; 3, $\$ 2.00$; doz. $\$ 7.00$.

\section{Papaver orientale (Oriental Poppy)}

There just isn't any other plant which can take the place of Oriental Poppies. They are hardy, easy to grow and last when once well started. The pale varieties are enchantingly beautiful while the brightly colored ones are spectacular enough to please the most particular lover of gay flowers. Plant them in groups throughout the border for May and June color.

Cavalier. Flowers crinkly, deep scarletred.

Gold of Ophir. Golden orange

Henri Cayeux. OId-rose.

Nancy. Deep crimson with black blotches. Perry's White. Satiny white, crimson blotch at base of peta

Purity. Pure soft pink.

Each 35c.; 3 of any one kind for $90 \mathrm{c}$. any 6 for $\$ 1.75$; doz. $\$ 3.00$.

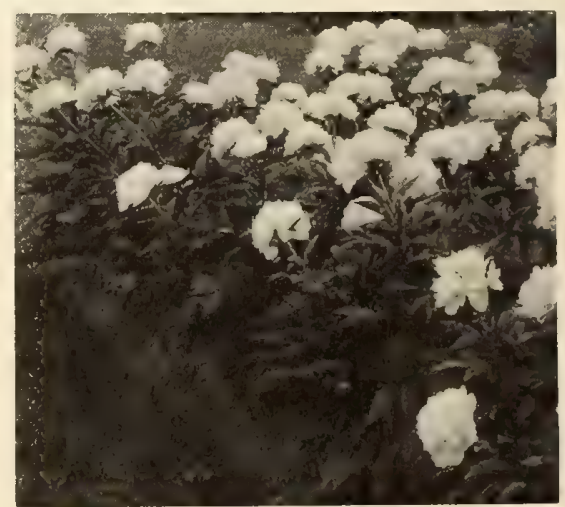

Peonies 
PRICES: Unless otherwise priced, all plants are sold at, each $30 \mathrm{c} . ; 3$ of any one variety $75 \mathrm{c}$.; 6 of any one variety at dozen rate; doz. $\$ 2.50$.

\section{Phlox decussata}

Colorful, fragrant Phlox are the glory of the summer garden, the large heads of colorful bloom appearing in July and lasting through August. Height varies from $1 \frac{\pi}{2}$ to 3 feet. Plants should be divided and replanted every 2 to 3 years. Do not allow flowers to go to seed or the seedlings will crowd out the wanted variety. Keep well watered and they will please you.

Africa. Carmine-red with blood-red eye. Betty Lou. Deep salmon overlaid with scarlet glow.

Count Zeppelin. White with red center. Daily Sketch. Salmon-pink with crimson center.

Enchantress. Light rose-pink shaded salmon-pink.

Ethel Pritchard. French mauve color. Strong grower.

Harvest Fire. Brilliant salmon-orange.

Leo Schlageter. Scarlet-red with orange cast.

Lillian. Cameo-pink with blue eye

Mia Ruys. An outstanding dwarf. Pure white.

Miss Lingard. Pure white flowers on 2 to 3 -foot stems.

Nordlicht. Rose-pink with touch of blue; deep red center.

Painted Lady. Silver-pink with salmon shading; cherry-red eye.

Rheinlander. A very popular salmonpink.

Starlight. Violet-red, shading to lilac; white center.

\section{Phlox subulata \\ (Moss or Mountain Pink)}

Low spreading plants with attractive foliage. They cover themselves with a mass of tiny flowers in ApriI and May. A leading rock-garden plant and desirable for wall gardening or they can be used as edgings. Try covering a bare spot with a few plants, they will soon become a thing of spring beauty.

Atropurpurea. Very showy brilliant red. Blue Hill. The finest lavender-blue.

June Jane. Large; pure white.

Vivid. Bright pink with fiery red eye.

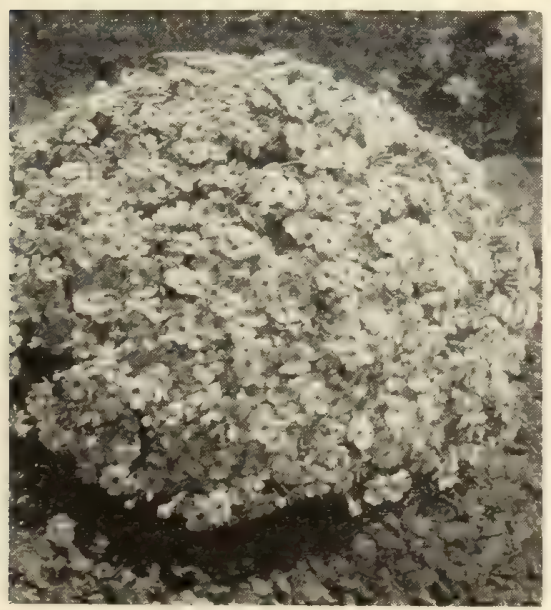

Phlox subulata

\section{Platycodon (Balloon Flower)}

A long-lived, dependable, tall border plant furnishing lovely flowers like little balloons which open to broad bells. They bloom from midsummer through September. Sun or light shade.

Grandiflorum cæruleum. Attractive blue flowers from July to October. $2 \mathrm{ft}$.

Grandiflorum Mariesi. Large, deep violet-blue flowers. 15 to $18 \mathrm{in}$.

Grandiflorum Mariesi album. Large; white.

\section{Plumbago (Leadwort)}

Larpentae. Dwarf, spreading plants 6 to 8 inches high with leathery, bronzy green foliage and beautiful violet-blue flowers in profusion from July to September. Plant in sun or partial shade in rather poor sandy soil.

\section{Rudbeckia (Coneflower)}

Tali-growing plants bearing large daisies with cone-like centers. They are easy to grow in fuIl sun in ordinary soil. Good background plants.

Maxima. Glaucous green leaves and bright yellow flowers 3 to 4 inches across, with a cone 2 inches high. Blooms all summer. 4 to $5 \mathrm{ft}$.

Purpurea. Giant purple flowers with brown cone-shaped center. Blooms July to October. $3 \mathrm{ft}$.

White Lustre. A new Coneflower with pure white petals and a bronzy gold cone. Starts to bloom in June and continues all summer. Stiff sturdy stems. $3 \mathrm{ft}$. Each 75c.; 3, \$2.00.

\section{Viola odorata (Sweet Violet)}

Loved by everyone, these beautiful flowers bring dainty beauty and haunting fragrance to the garden. One never has enough of them. Plant in well-manured soil. Some shade is always beneficial.

Double Russian. Very sweet-scented double flowers. Best planted in shade. Each $35 c$. ; 3, 90c.

Prince of Wales. Large deep blue flowers. Rosina. The new pink fragrant Violet. Blooms in spring and again in fall.

\section{Clematis}

The modern Clematis hybrids provide masses of beautiful large flowers on hardy plants during late spring and summer. Place the plants in well-limed rich but light soil, setting the crowns so they will be covered at least 2 inches deep. The vines appreciate shade over their roots. Thrives almost anywhere.

Duchess of Edinburgh. Elegant Iarge double white flowers. Each $75 \mathrm{c}$.

Jackmani. Large purple-blue flowers in profusion. Each $75 \mathrm{c}$.

Mme. Baron Veillard. Large flowers of Iilac-rose. Each 75c

Mme. Edouard Andre. Large rosy carmine flowers. Each $75 \mathrm{c}$.

Paniculata (Virgin's Bower). Stronggrowing vines with masses of fragrant white flowers in August and September. Each 50c.; 3, \$1.25.

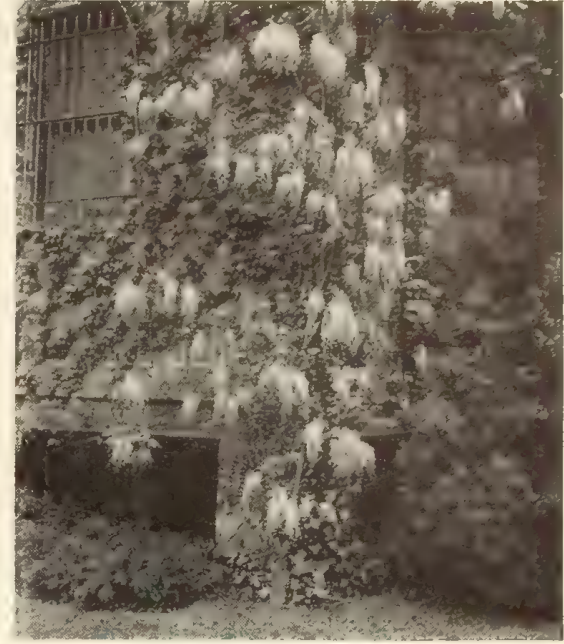

Wisteria sinensis

\section{Perennial Vines}

Bittersweet (Celastrus articulatus). The Oriental Bittersweet is a strong-growing vine bearing attractive clusters of orange-yellow and scarlet fruits which are in demand for fall and winter decorative use. Each 50c.

Boston Ivy (Ampelopsis Veitcbi). A hardy climber which clings to brick or stone walls. In autumn the foliage turns to scarlet and crimson. Each $40 \mathrm{c}$.

English lvy (Hedera Helix)

Beautiful English Ivy is a favorite wallcovering and one of the finest of all groundcovers, especially in shade. Each 15c.; doz. $\$ 1.50$.

\section{Polygonum Auberti (Silver Lace Vine)}

This hardy fast-growing vine reaches a height of 25 feet and covers itself in summer and fall with foamy sprays of white flowers. Not bothered by ordinary pests. Each 75c.; 3, \$2.00.

\section{Wisteria}

The most beautiful of all flowering vines It is hardy and when in full bloom, with its long racemes of fragrant flowers, is an unforgettable picture. Blooms best in full sun in good garden soil.

Sinensis. Delicate violet-blue flowers in 2 to 3 -foot long flower clusters in spring. Each 75 c.

Alba. White form of the above. Each $75 \mathrm{c}$

Ground-Covers for Shady Spots

The two following plants, together with

English Ivy, provide three of the finest ground-covers known.

Pachysandra. A trailing plant, 6 to 8

inches high, forming a complete cove of bright glossy green foliage and small spikes of flowers during May and June. Doz. $\$ 1.75 ; 100, \$ 12.00$.

Vinca minor (Periwinkle or Trailing Myrtle). An excellent dwarf trailing plant for carpeting the ground where it is too shady for other plants to thrive. Doz. $\$ 1.50 ; 100, \$ 10.00$.

NOTE: Be sure to include Postage and Packing Charges with your order. See top of page 44 . 


\section{Flowering Shrubs, Hedge Plants, Ornamental and Shade Trees}

Prices quoted include delivery in Washington, D. C., and vicinity. We do not ship nursery stock

We handle only first-class stock, but as there are so many conditions upon which successful growth is dependent and over which we have no control, we cannot guarantee nursery stock

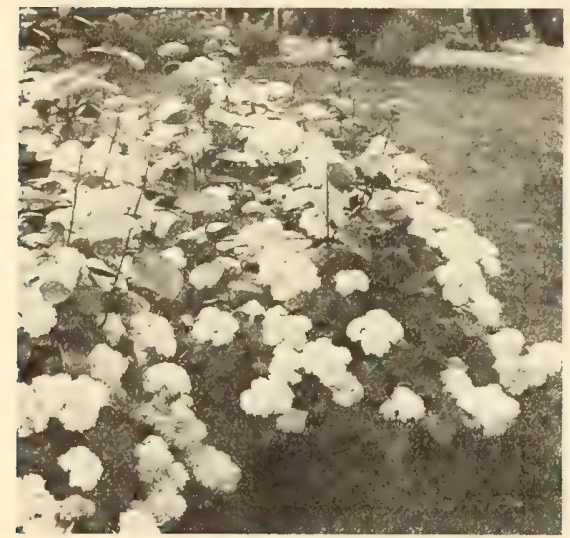

Hydrangea arborescens

ALTHAEA frutex (Rose of Sharon). Lovely double blooms from July to October. Pink, White, and Violet-Red. 2 to $3 \mathrm{ft}$., each $65 \mathrm{c}$.; 3 to $4 \mathrm{ft}$., $90 \mathrm{c}$.; 4 to $5 \mathrm{ft} ., \$ 1.35$. BEAUTY BUSH (Kolkwitzia amabilis). Pink flowers in early May, 2 to $3 \mathrm{ft}$. each $65 \mathrm{c}$ - 3 to $4 \mathrm{ft}, 90 \mathrm{c}$.

BUTTERFLY BUSH, Charming (Buddleia). New pink variety. 2-yr. plants, each $\$ 1.35$.

BUTTERFLY BUSH, lle de France. Long spikes of brilliant rosy violet-purple flowers from July to frost. 3-yr. plants, each 90c.

CALYCANTHUS floridus (Sweet-smelling Shrub). Brown, fragrant blooms in spring. 2 to $3 \mathrm{ft}$., each $65 \mathrm{c}$.; 3 to $4 \mathrm{ft}$., $90 \mathrm{c}$.

CORALBERRY (Symphoricarpos vulgaris) Compact shrub 4 to 5 feet high, with many clusters of deep red berries through the winter months. Excellent for winter bouquets. A good shrub for massing on
hillsides. 18 to 24 in., each $65 \mathrm{c}$; 2 to $21 / 2$ $\mathrm{ft} ., 90 \mathrm{c}$

CREPE MYRTLE. Red, Pink, White or Lavender. 18 to 24 in., each 90c.; 2 to 3 $\mathrm{ft}$., $\$ 1.35 ; 3$ to $4 \mathrm{ft}$., $\$ 1.75$.

DEUTZIA crenata flore-pleno. Double rose-colored flowers. 3 to $4 \mathrm{ft}$., each $90 \mathrm{c}$. 4 to $5 \mathrm{ft}$., $\$ 1.35$

D., Pride of Rochester. Large double white flowers tinged with rose. 3 to $4 \mathrm{ft}$., each 90c.; 4 to $5 \mathrm{tt}$., $\$ 1.35$.

FLOWERING ALMOND. When in bloom, in early spring, the bushes are completely snuggling tightly to the twigs. Double Pink or White. 18 to 24 in., each $90 \mathrm{c}$. 2 to $3 \mathrm{ft}$., $\$ 1.15$

FORSYTHIA intermedia spectabilis (Golden Bell). Strong erect bush with bright yellow bell-like flowers in early

F. suspensa (Weeping Golden Bell). Tall shrub of willowy growth with graceful, in early $4 \mathrm{fi} ., 90 \mathrm{c}, ; 4$ to $5 \mathrm{ft}$. $\$ 1.35$.

HYDRANGEA arborescens grandiflora. White almost round heads of flowers in June and July. 3 to $4 \mathrm{ft}$,, each $75 \mathrm{c}$; 4 to $5 \mathrm{ft}$., $90 \mathrm{c}$

H., Blue or Pink. 15 to $18 \mathrm{in}$., each $70 \mathrm{c}$;

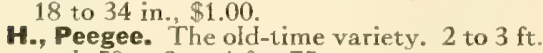
each $50 \mathrm{c} . ; 3$ to $4 \mathrm{ft} ., 75 \mathrm{c}$

LILAC, Old-fashioned Purple. 2 to $3 \mathrm{ft}$., each $90 \mathrm{c}$; 3 to $4 \mathrm{ft}$., $\$ 1.35$.
LILACS, French Hybrids. Larger panicles, richer coloring.

Marie Legraye. Pure white.

Mme. Lemoine. Large; double; white.

President Grevy. Light blue.

Souv. de Ludwig Spaeth. Dark purple. Any of above, 2 to $3 \mathrm{ft}$., each 85c.;

3 to $4 \mathrm{ft}$., $\$ 1.25 ; 4$ to $5 \mathrm{ft}$., $\$ 1.75$

PHILADELPHUS virginalis (Mock Orange). Clusters of large semi-double white flowers borne profusely in summer. Best hybrid. 2 to $3 \mathrm{ft}$, each $70 \mathrm{c}$; 3 to 4

ROSA Mugonis (Golden Rose of China). Fragrant, soft yellow silken flowers in yard-long sprays when the late tulips
bloom. Shrub-like plant. 2 to $3 \mathrm{ft}$., each $90 \mathrm{c}$; 3 to $4 \mathrm{ft}$., $\$ 1.35$.

R. rugosa. A shrub Rose with dark crinkled foliage. Blooms until frost. Red fruits that are most ornamental. Pink, White, or
Red. 18 to 24 in., each $70 \mathrm{c}$.; 2 to $3 \mathrm{ft}$., $90 \mathrm{c}$. SNOWBALL (Viburnum Opulus sterile). Flowers like large white balls in May or Flowers inke large white balls in May or
June. 2 to $3 \mathrm{ft}$., each $65 \mathrm{c}$.; 3 to $4 \mathrm{ft}$., $90 \mathrm{c}$.

SNOWBERRY (Symphoricarpos racemosus). Pink flowers in summer followed by many marble-sized waxy white berries on graceful branches from September until midwinter. Grows well in shade and reaches
height of 4 to $5 \mathrm{ft}$. 18 to 24 in., each $70 \mathrm{c}$. 2 to $21 / 2 \mathrm{ft}$., $90 \mathrm{c}$.

SPIRAE, Anthony Waterer. Dwarf bush. Crimson flowers all summer. 15 to 18 in., each $65 \mathrm{c}$.; 18 to 24 in., $90 \mathrm{c}$.

S. prunifolia (Bridal Wreath). White double flowers. Early. 3 to $4 \mathrm{ft}$, each 90c.; 4 to $5 \mathrm{ft}, \$ 1.35$.

s. Vanhouttei. The most popular variety. Blooms in June. 3 to $4 \mathrm{ft}$., each $90 \mathrm{c}$; 4 to $5 \mathrm{ft}$., $\$ 1.35$.

S. Thunbergi. Arching branches and long sprays of white flowers in early spring. Fine-leaved foliage. 18 to 24 in., each $50 \mathrm{c}$. 2 to $3 \mathrm{ft}$., 65

VIBURNUM Carlesi (Mayflower Viburnum). Produces many waxy flower
clusters in earlv spring, lovely pink in bud, clusters in early spring, lovely pink in bud,
opening to pure white, and exquisitely fragrant. Does well in partial shade and in slightly moist soil. 12 to 15 in., each $\$ 1.75$; 15 to 18 in., $\$ 2.50$.

WEIGELA rosea. Beautiful free-blooming shrub much used in borders and as speciman plants on the lawn. Pink flowers in May and June. 2 to $3 \mathrm{ft}$, , each $65 \mathrm{c} . ; 3$ to $4 \mathrm{ft}$., $90 \mathrm{c}$.; 4 to $5 \mathrm{ft}$., $\$ 1.35$.

W., Eva Rathke. A variety with carminered blooms in June and July. 2 to $3 \mathrm{ft}$., each $65 \mathrm{c}$; 3 to $4 \mathrm{ft}$., $90 \mathrm{c}$

\section{Ornamental and Shade Trees}

BIRCH, European White (Betula alba) Prized for its smooth white bark. Does well in poor soil. 5 to $6 \mathrm{ft}$., each $\$ 2.75 ; 6$ to 8

CRAB, Flowering (Malus floribunda). Buds are a warm rose-color opening to light pink flowers - the whole forming a shapely bush or small tree. 5 to $6 \mathrm{ft}$.,

DOGWOOD. Everyone knows and loves the Dogwood. It needs no description.

Pink-flowering. 2 to $3 \mathrm{ft}$., each $\$ 2.00 ; 3$ to $4 \mathrm{ft}$., $\$ 3.50 ; 4$ to $5 \mathrm{ft}$, $\$ 5.00 ; 5$ to $6 \mathrm{ft}$., $\$ 6.75$. White-flowering. 2 to $3 \mathrm{ft}$., each $\$ 1.35$; 3 to $4 \mathrm{ft}$., $\$ 1.75 ; 4$ to $5 \mathrm{ft}$., $\$ 4.50 ; 5$ to $6 \mathrm{ft}$. $\$ 5.50$.
ELM, American. Graceful high-arching branches, leaving good space above roof for air and diffused light. 6 to $8 \mathrm{ft}$., each $\$ 1.75 ; 8$ to $10 \mathrm{ft}$., $\$ 2.50$.

E., Chinese. Grows rapidly to a good height and develops a broader base than the American type. Foliage small and dense. Growth symmetrical. 5 to $6 \mathrm{ft}$., each $\$ 1.75$; 6 to $8 \mathrm{ft}$., $\$ 2.50 ; 8$ to $10 \mathrm{ft}$., $\$ 4.50$.

LINDEN, American. A stately tree, growing 75 to 90 feet, with large shining, cordate leaves. Fragrant yellow flowers in July. Valuable for its white wood. 6 to $8 \mathrm{ft}$., each $\$ 2.50 ; 8$ to $10 \mathrm{ft}$. $\$ 3.25$.

MAGNOLIA Soulangeana (Saucer Magnolia). A hardy Chinese species, with beautiful cup-shaped flowers 3 to 5 inches in diameter, white inside, flushed with pink outside. 2 to $3 \mathrm{ft}$, each $\$ 3.50: 3$ to $4 \mathrm{ft}$., $\$ 4.50 ; 4$ to $5 \mathrm{ft}$., $\$ 6.75 ; 5$ to $6 \mathrm{ft}$., $\$ 9.00$. M. stellata (Star Magnolia). A well-shaped. tree attaining a height of from 10 to 12 feet, and bearing in great abundance pure white star-like flowers with delightfut fragrance. 15 to $18 \mathrm{in}$., each $\$ 2.50 ; 18$ to 24 in., $\$ 3.75 ; 2$ to $21 / 2$ ft., $\$ 5.25$.

MAPLE, Silver. The fastest growing Maple. Prune to a single stem for best form. 6 to $8 \mathrm{ft}$., each $\$ 1.75 ; 8$ to $10 \mathrm{ft}$., $\$ 2.50$.

M., Sugar. The Maple Sugar Tree. 6 to 8 t., each $\$ 3.50 ; 8$ to $10 \mathrm{ft}$., $\$ 4.00$

OAK, Pin. Sharply cut leaves and weeping lower branches. A good street tree. 6 to $8 \mathrm{ft}$., each $\$ 3.50 ; 8$ to $10 \mathrm{ft}$. $\$ 4.00$.

O., Red. A deep-rooting tree under which it is easy to grow grass. 6 to $8 \mathrm{ft}$., each $\$ 3.25$; 8 to $10 \mathrm{ft}$., $\$ 4.75$.

PLANE, Oriental. An 80 -foot wide-spreading tree that thrives in all soils, even at the waterside. Peculiarly attractive in winter $\$ 2.50 ; 8$ to $10 \mathrm{ft}$., $\$ 3.75 ; 10$ to $12 \mathrm{ft}$., $\$ 4.75$.

POPLAR, Lombardy. Tall, columnar tree attaining a height of 60 feet. Useful for formal plantings and screens. 6 to $8 \mathrm{ft}$., each $90 \mathrm{c}$.; $10, \$ 7.00 .8$ to $10 \mathrm{ft}$., each $\$ 1.35$; $10, \$ 10.00$. 10 to $12 \mathrm{ft}$., each $\$ 1.75$.

wILLOW, Weeping. A pendulous-branched tree, 40 feet high that is very effective when planted at the waterside. 6 to $8 \mathrm{ft}$., each $\$ 2.50 ; 8$ to $10 \mathrm{ft}$., $\$ 3.75$.

\section{Hedge Plants}

BARBERRY, Green-Leaf. The best and most practical low hedge plant. It also makes a good footing or base planting near the house, or as a border plant in front of tall-growing shrubs. They can be allowed to grow naturally or pruned into any hedge form desired. 12 to 15 in., $10, \$ 1.50$; $100, \$ 11.50$; 15 to $18 \mathrm{in}$., $10, \$ 2.25$; 100 , $\$ 17.50 ; 18$ to $24 \mathrm{in}, \$ 3.00 ; 100, \$ 22.50$.

BARBERRY, New Red-Leaf. The foliage of this variety is always brilliant crimson. 12 to $18 \mathrm{in}$., each $65 \mathrm{c}$. $10, \$ 6.00 .18$ to 24 in, each $90 \mathrm{c}$; $10, \$ 8.00,2$ to $3 \mathrm{ft}$., each $\$ 1.40$.

PRIVET, California. The best-known hedge plant. Dark green foliage which remains on the plant untrl midwinter. $10, \$ 1.00 ; 100, \$ 8.00$. 2 to $3 \mathrm{ft}$., $10, \$ 1.50$; $100, \$ 12.00$.

ALL PRICES ON THIS PAGE ARE SUBJECT TO MARKET CHANGES 


\section{Evergreens, Trees and Shrubs}

\section{Tall Evergreens}

ARBORVITAE, American. Tall, rapid

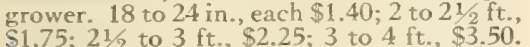

A., Pyramidal. Darker green, denser foliage ana more slender of shape than American. 2 to $3 \mathrm{ft}$., each $\$ 2.50 ; 3$ to $4 \mathrm{ft}$., $\$ 3.75$.

BIOTA compacta. A thick, columnar evergreen. 2 to $3 \mathrm{ft}$., each $\$ 1.75 ; 3$ to $4 \mathrm{ft}$. $\$ 2.75 ; 4$ to $5 \mathrm{ft}$., $\$ 3.75 ; 5$ to $6 \mathrm{ft}$. $\$ 4.50$.

FIR, Balsam. Foliage dark above, pale beneath. 18 to $24 \mathrm{in}$., each $\$ 2.50 ; 2$ to $3 \mathrm{ft} ., \$ 3.50 ; 3$ to $4 \mathrm{ft}$., $\$ 5.00$.

HEMLOCK. Best evergreen for the shade. Will stand close shearing and makes a good hedge. 15 to $18 \mathrm{in}$., each $\$ 1.75 ; 18$ to 24 in., $\$ 2.25 ; 2$ to $2 \frac{1}{2} \mathrm{ft}$., $\$ 2.75$.

JUNIPER, Irish. Tall, narrow spires of blue-green foliage. Fast growing. 2 to 3 $\mathrm{ft}$, each $\$ 1.75 ; 3$ to $4 \mathrm{ft}$., $\$ 2.50 ; 4$ to $5 \mathrm{ft}$. $\$ 3.75 ; 5$ to $6 \mathrm{ft}$., $\$ 5.25$.

RETINOSPORA plumosa. Graceful plume-like foliage of a pretty green. 18 to 24 in., each $\$ 1.75 ; 2$ to $21 / 2 \mathrm{ft}$., $\$ 2.50$.

R. plumosa aurea. Golden tipped. 18 to 24 in., each $\$ 1.75 ; 2$ to $21 / 2 \mathrm{ft}$., $\$ 2.50$.

SPRUCE, Koster Blue. 18 to 24 in., each $\$ 3.75 ; 2$ to $21 / 2 \mathrm{ft}$., $\$ 4.50 ; 21 / 2$ to $3 \mathrm{ft}$., $\$ 5.50$.

YEW, Upright (Taxus cuspidata capitala) Symmetrical in shape, bearing brilliant scarlet fruits which are very attractive against the black-green foliage. 15 to 18 in., each $\$ 2.50 ; 18$ to 24 in. $\$ 3.25 ; 2$ to $21 / 2 \mathrm{ft}$., $\$ 5.25 ; 21 \frac{1}{2}$ tc $3 \mathrm{ft} ., \$ 6.75$.

\section{Dwarf Evergreens}

ARBORVITAE, Globe. Globe-shaped evergreen with dense dark green foliage. Used in large tubs or for entrance planting.
BIOTA aurea mana. A dwarf pyramidalshaped evergreen, with gold-tipped foliage. 10 to $12 \mathrm{in}$., each $\$ 1.35 ; 12$ to $15 \mathrm{in}$., $\$ 1.75$. 15 to $18 \mathrm{in}$., $\$ 2.25 ; 18$ to $24 \mathrm{in}$., $\$ 2.50$.

JUNIPERUS chinensis Pfitzeriana (Pfitzer's Juniper.) Low, spreading; dark green branches. Very effective when used among other types in the foundation planting. 12 to $15 \mathrm{in}$, each $\$ 1.75$; 15 to 18 in., $\$ 2.75$.

J. depressa (J.communis depressa plumosa; Purple Spreading Juniper), 12 to $15 \mathrm{in.}$ each $\$ 1.35 ; 15$ to 18 in., $\$ 1.75$.

J., Tamarix (J. Sabina tamariscifolia). A spreading, prostrate evergreen. 12 to 15 in. each $\$ 1.75$; 15 to $18 \mathrm{in}$. $\$ 2.25 ; 18$ to $24 \mathrm{in}$. 2.75

PINE, Mugho (Dwarf Pine). Gray foliage; compact: very ornamental 12 to 15 in. each $\$ 2.00 ; 15$ to 18 in. $\$ 2.75 ; 18$ to $24 \mathrm{in}$. $\$ 3.50 ; 2$ to $21 / 2 \mathrm{ft}$., $\$ 4.50$.

YEW, Spreading (Taxus cuspidata). Moderately bushy growth. Branches densely clothed with short dull green leaves. 12 to 15 in., each $\$ 2.00 ; 15$ to 18 in., $\$ 2.50$; 18 to 24 in., $\$ 3.75$.

\section{Broad-leaved Evergreen Shrubs}

ABEL:A grandiflora (Bush Arbutus). An evergreen shrub, with dark green glossy eaves, becoming bronze-colored in winter. Flower white, funnel-shaped, tinged with pink, delicately sweet-scented, borne in clusters from early spring until late autumn. 15 to $18 \mathrm{in.,}$ each $90 \mathrm{c}$; 18 to $24 \mathrm{in}$., $\$ 1.35 ; 2$ to $21 / 2 \mathrm{ft} ., \$ 1.75$.

AZALEA amona (Purple Azalea) 8 $10 \mathrm{in}$, each $\$ 1.25$; 10 to $12 \mathrm{in.,} \$ 1.50$.

A. Hinodegiri. Low-growing. Brilliant scarlet flowers and evergreen leaves. 8 to 10 in., each $\$ 1.75 ; 10$ to 12 in., $\$ 2.25$; 12 to $15 \mathrm{in} ., \$ 2.75$.

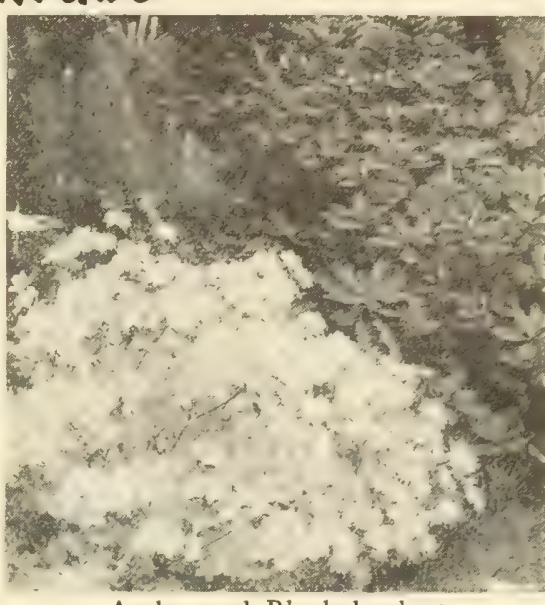

Azalea and Rhododendron

Azalea Kurume (Coral Bell). Clear pink. 8 to $10 \mathrm{in}$., each $\$ 1.50 ; 10$ to 12 in., $\$ 1.75$. A., Snow. Pure white. 8 to $10 \mathrm{in}$., each $\$ 1.50$; 10 to $12 \mathrm{in}$., $\$ 1.75 ; 12$ to $15 \mathrm{in.}, \$ 2.50$.

BOXWOOD, old English (Buxus suffruti$\cos a$ ). Very slow-growing. Fine for edging or borders. 4 to $6 \mathrm{in}$. high, each $25 \mathrm{c}$; 10 , $\$ 2.00 .8$ to $10 \mathrm{in}$. high, each $90 \mathrm{c}$

B., American (B. sempervirens). The faster growing variety. 8 to $10 \mathrm{in}$., each $75 \mathrm{c}$. 18 in., each $\$ 2.00$

LAUREL, Mountain.

RHODODENDRON catawbiense. col to 24 in

R. maximum (Rosebay). Large pink to whrte flowers 18 to 24 in., each \$2.25; 2 to $2 \frac{1}{2} \mathrm{ft} ., \$ 3.00 ; 21 / 2$ to $3 \mathrm{ft}$. $\$ 3.75$.

R. carolinianum. Pink, 18 to $24 \mathrm{in}$, each $\$ 2.50 ; 2$ to $21 / 2 \mathrm{ft} ., \$ 3.50$

\section{Fruits and Berries}

\section{$\checkmark$ APPLE TREES}

4 to $6 \mathrm{ft}$., 2-yr.-old, each $\$ 1.03$

\section{Winter Varieties}

Delicious. Fruit large, dark red. Flesh fine-grained, crisp and melting, juicy with a delightful aroma. Annual bearer.

Stayman (Improved Winesap). Red; Iarge. More prolific.

York Imperial. Yellow, blush cheek. An early and good producer.

\section{Autumn Varieties}

Grimes Golden. Good size; yellow; of highest quality. Productive.

\section{Summer Varieties}

Early Marvest. Medium. Pale yellow; Yellow Transparent. Earliest. White skin changing to pale yellow.

\section{CHERRY TREES}

5 to $6 \mathrm{ft}$., each $\$ 1.25$

Early Richmond. Sour, light red fruit. Bears about the middle of June.

Montmorency. Sour variety. Bears Iast of June.

Napoleon. Large; sweet. Good quality. Midseason.

Tartarian. Large, sweet, black Cherries in June.

\section{PEAR TREES}

5 to $6 \mathrm{ft}$., each $\$ 1.00$

Bartletk. The best, large eating Pear. Seckel. Small; sweet. Very popular.

\section{PEACH TREES}

4 to $5 \mathrm{ft}$., each $\$ 1.00$

Belle of Georgia. Large; white flesh. Freestone.

Carman. White flesh. Early and large. Semi-clingstone.

Elberta. Large; yellow flesh. Freestone. A few days later than Belle of Georgia.

\section{PLUM TREES}

5 to $7 \mathrm{ft}$., each $\$ 1.00$

Abundance. The popular early cherry-red

Burbank. A well-known dark red early variety.

\section{GRAPE-VINES}

Caco. Large wine-red berries. Each $40 \mathrm{c}$.

Concord. The standard black.

Lucile. Light red wine Grape.

Moore's Early. Large; black.

Niagara. White.

All Grape-Vines, except where noted, each 30c.; $6, \$ 1.50$

\section{RED RASPBERRY PLANTS}

Delivery March 15 to June -1

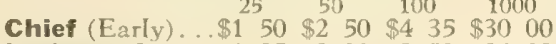
Latham (Late). $\begin{array}{lllllllll}1 & 25 & 2 & 00 & 3 & 50 & 24 & 00\end{array}$ Newburgh

(Midseason) . $14140 \quad 225 \quad 385 \quad 2700$

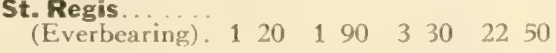

BLACK RASPBERRY PLANTS

Cumberland. .. $25 \quad 50 \quad 50 \quad 100 \quad 1000$ STRAWBERRY PLANTS

Delivery March 15 to May 15. 100 to 475 plants at 100 rate, 500 at 1000 rate. No plants shipped C. O. D.

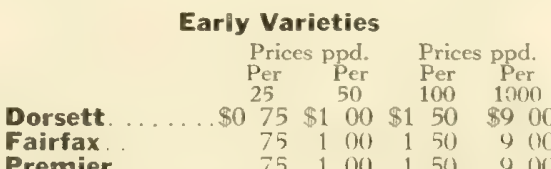

Fairfax

Midseason Varieties

Big Joe. ....... \$0 $75 \quad \$ 100 \quad \$ 1 \quad 50 \quad \$ 900$ $\begin{array}{lllllllll}\text { Catskill....... } & 75 & 1 & 00 & 1 & 50 & 9 & 00\end{array}$

Pathfinder... $75 \quad \begin{array}{lllllll}75 & 00 & 1 & 50 & 9 & 00\end{array}$

Late Varieties

Chesapeake.... $\$ 100 \quad \$ 140 \quad \$ 1 \quad 90 \$ 1100$ $\begin{array}{lllllllll}\text { Red Star....... } 1 & 00 & 1 & 40 & 1 & 90 & 11 & 1.0 \\ \text { Starbright...... } & 00 & 1 & 40 & 1 & 50 & 11 & 00\end{array}$

Everbearing Varieties

Mastodon..... \$1 $25 \quad \$ 165 \$ 275 \$ 160$

\section{BLACKBERRY PLANTS}

(Midseason) . . \$1 $40 \$ 2 \quad 25 \$ 3 \quad 85 \$ 2700$

\section{BOYSENBERRY PLANTS}

$1-y$ r. No. 1 Plants $\$ 200 \$ 300 \$ 500 \$ 3300$ 


\section{Two Pages of Great Plants}

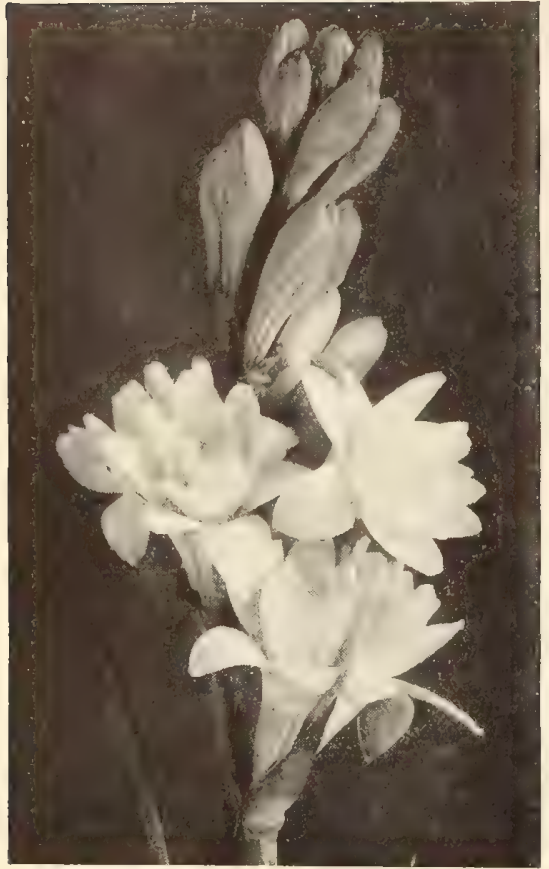

\section{Tuberoses}

Excelsior Double Pearl. Delightfully fragrant white flowers. Plant in the garden as soon as afl danger from frost is past. Postpaid, large bulbs, each 10c. 10,65 c. Not postpaid, each $6 \mathrm{c}$. $; 10,50 \mathrm{c}$. $25, \$ 1.00 ; 100, \$ 3.50$.

\section{Ismene calathina \\ (Peruvian Daffodil)}

A Iovely white lily-like bloom with a greenish tinge. The bulb is not hardy and should be planted in the spring. It blooms within a few weeks after planting. As a general rule, the foliage is only partly developed at the time of its blooming period. It is fragrant and greatly admired by those who know it. Postpaid, each 25 c.; doz. $\$ 2.50$.

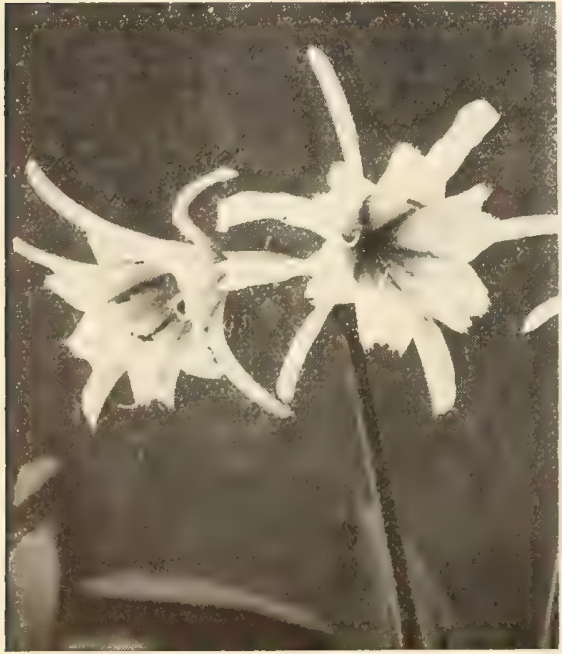

Ismene calarnuna
On pages 51 and 52 we offer a group of plants providing exceptional decorative value. Plants like Cannas and Caladiums are showy, and beds of them provide pleasing exotic pictures. Gladiolus are beautiful in the garden, and few ever have enough plants to supply the desire for "Glads" in the house. They are superb cut-flowers.

Tuberoses, the Peruvian Daffodil and the two Vines should be planted for their fragrance, even if they were not goodlooking, but they are, so are doubly valuable. These are all important garden plants.

\section{Cinnamon Vine}

A hardy climber which grows very rapidly. The foliage is bright green and the white flowers are cinnamon-scented. Postpaid, tubers, each 10c.; 10, 90c.

\section{Madeira Vine}

A very quick-growing vine bearing graceful feathery white flowers of a delightful fragrance. Postpaid, tubers, each $10 \mathrm{c}$; $10,90 \mathrm{c}$

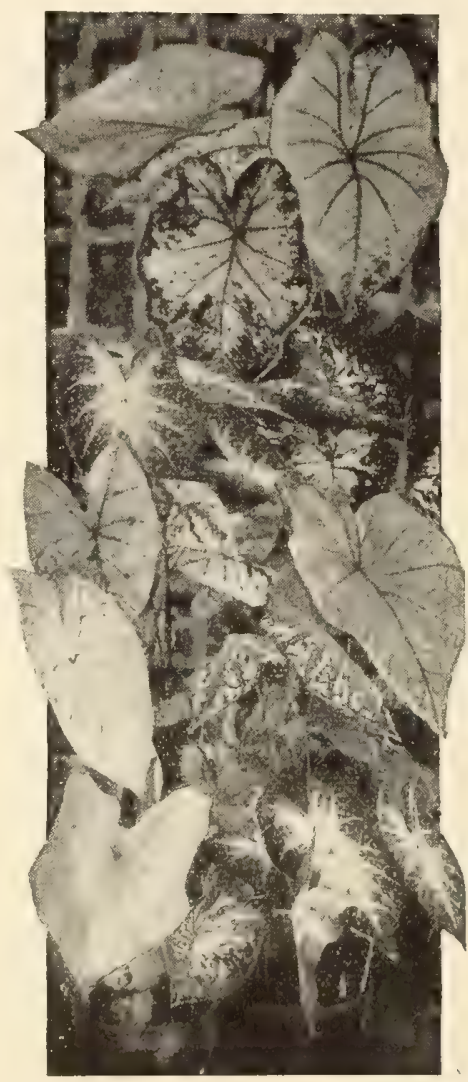

Fancy-leaved Caladiums

Rich and gorgeous-colored foliage. Plant outdoors in early May. Excellent for the conservatory, window-boxes and outdoor beds. Mixed colors. Postpaid, bulbs, each 25 c. ; doz. $\$ 2.50$

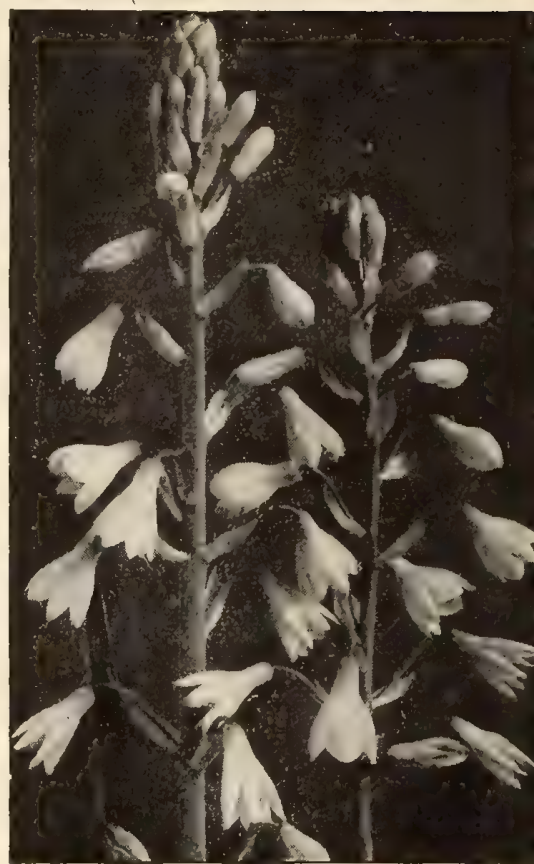

\section{Hyacinthus candicans}

(Summer-flowering Hyacinth)

A luxuriant, free-flowering plant bearing 20 to 30 bell-shaped flowers of creamy white in clusters on spikes 2 to 3 feet long. Postpaid, choice bulbs, each 15c.; doz. $\$ 1.50$.

\section{Caladium (Elephant's Ear)}

Wonderful plants for Iawns, borders or backgrounds. To obtain the maximum growth they should be planted in rich soil where they will get plenty of water. A full-sized plant will stand 6 feet high and bear immense leaves 3 to 4 feet long by 27 inches wide. They should not be planted outdoors until May 1, but to get them into early growth they can be started in pots in the house.

Mammoth Bulbs, each 25c.; 10, $\$ 2.00$ Large Bulbs, each 15c.; $10, \$ 1.25$.

Add 10c. each for postage, or 35c. for 10 .

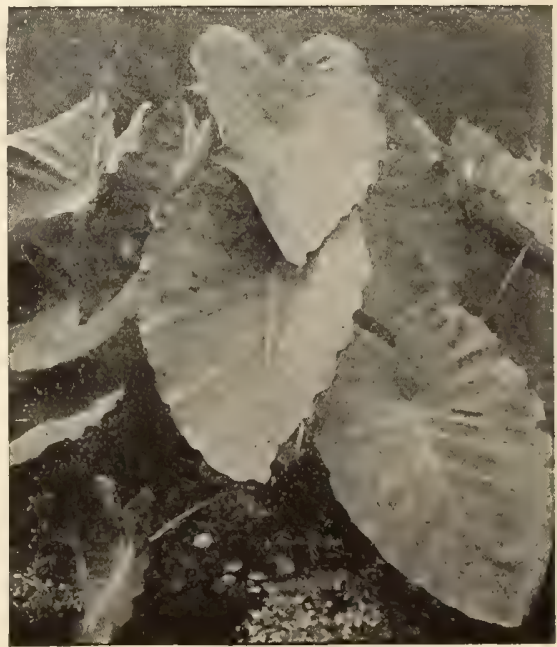

Caladium (Elephant's tar) 


\section{Flowering Bulbs and Roots}

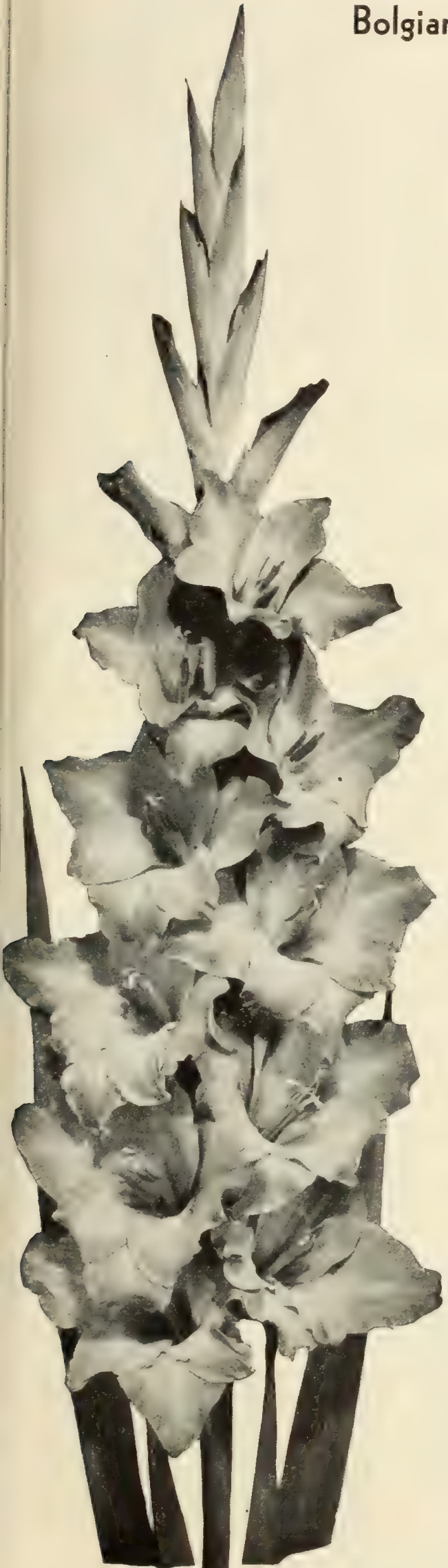

\section{Bolgiano's Cannas}

two weeks, from April 15 until July 1, for bright masses of garden color all summer and plenty of cut-flowers. Plant the bulbs 4 to 6 inches deep and 6 inches apart. Blooming Dates: (E) Very Early, (EM) Early Midseason, (M) Midseason, (LM) Late Midseason, (L) Late to very late.

TWO NOVELTIES for 1943

BLUE BEAUTY. (E) A beautiful light blue flower, darker toward the edges. No garden is complete without it. Postpaid, each 8c.; doz. 85c.; 100, $\$ 6.00$. LAVENDER RUFFLES. Soft Iavender, cream throat. Postpaid, each 8c.; doz., 85 c.; $100, \$ 6.00$.

\section{Ten Superfine Gladiolus}

Beacon. (EM) Brilliant, clear, dark rose, with a pronounced blotch. Florets slightly waved and ruffled. No garden is complete without it.

Canberra. (L) Intense yellow. A consistent prize-winner.

Commander Koehl. (M) Very large clear blood-red. Tall, straight spikes.

Dream o'Beauty. (M) Am. Beauty shade.

Minuet. (M) Beautiful clear light Iavender. Easily the best lavender.

Mother Machree. (L). Vinaceous Iavender overlaid with salmon-pink toward edges of the petals. Might be called a "smoky."

Mrs. E. J. Heaton. (M) Glowing saImon with cream throat.

Peggy Lou. (M) Smooth, shrimp-pink.

Pelegrina. (M) A velvety deep blueviolet. A prize-winner.

Shirley Temple. (L) Light cream. Florets creased and ruffled.

Postpaid, any of above, each $8 \mathrm{c}$.; doz. $80 \mathrm{c}$. ; $100, \$ 5.75$.

Not postpaid, each 7c.; doz. 70c.; 100, \$5.25.

\section{Best 10 Standard Varieties}

Debonair. (LM) La-France-pink, cream throat; long flower-head.

Excellence. (E) Scarlet; large; excellent cut-flower and garden variety.

Golden Dream. (L) Clear deep yellow, no markings. One of the best yellows.

King Arthur. (EM) Very deep-toned lavender. Large ruffled florets.

La Fiesta. (M) Bright orange, deeper in throat. Strong stem.

Maid of Orleans, (M) Creamy white.

Picardy. (LM) Soft apricot-pink with silvery sheen. A strong grower.

Red Phipps. (M) Rich and glowing. Free flowering; long spikes.

Sonatine. (M) Light pink, flaked darker; small diffused red feathering. Van Tienhoven. (L) Fine brilliant red.

Postpaid, any of above, each $6 \mathrm{c}$.; doz. $55 \mathrm{c}$. $100, \$ 3.75$.

Not postpaid, each $5 \mathrm{c}$. ; doz. $45 \mathrm{c}$.; $100, \$ 3.25$.

Capitol City Mixed Gladiolus

In our Capitol City Mixture, which contains most all of the named sorts, we have also included a large number of other varieties of Gladiolus and have produced a mixture which cannot fail to satisfy. The color-range is very wide and is composed of large-flowered varieties. Postpaid, doz. 50 c.; $100, \$ 3.50$. Not postpaid, doz. $45 \mathrm{c}$; $100, \$ 3.00$.

Cannas bloom from early summer until
rost. For best results, spade the beds 2 feet deep and incorporate in the soil liberal amount of well-decayed manure of any kind. Water well at all times. Set the plarts 18 inches apart.

Ambassador. Rich cherry-red flowers of immense size. Foliage and stalks bronze. $4 \mathrm{ft}$.

Apricot. Buff-yellow base overspread with salmon-pink, making a mass effect of rich apricot. Green foliage. $4 \mathrm{ft}$.

City of Portland. Contrasting with the rich, deep green foliage are flowers of bright pink color. $5 \mathrm{ft}$.

Eureka. A beautiful creamy white Canna with large, bold flowers. The foliage is rich dark green. $4 \mathrm{ft}$.

Hungaria. Large flower-trusses of heav substance, carried on strong stems. The magnificent blooms are a shade of rosepink. $4 \mathrm{ft}$

King Humbert. Large, heart-shaped, purplish bronze leaves forming a sharp contrast to the immense blooms which are velvety orange-scarlet, rose-tinted and margined at the base. $4 \mathrm{ft}$

Mrs. Alfred F. Conard. Gigantic flowers borne in immense clusters; color, delightful saImon-pink. Foliage light green. $4 \mathrm{ft}$.

Richard Wallace. Large, showy, pure canary-yellow flowers carried on good stems. Green foliage. $4 \mathrm{ft}$.

The President. Rich, glowing scarlet; superior in quantity and quality of bloom to any other red variety. Green foliage. $4 \mathrm{ft}$.

Wintzer's Colossal. Flowers frequently 8 inches in diameter, bright scarlet; very effective. Free-flowering bedding variety. $5 \mathrm{ft}$.

Yellow King Humbert. A sport of the well-known bronze-leaved variety, but with green foliage. Masses of golden vellow flowers, dotted red; occasionall some will be streaked red. $4 \mathrm{ft}$.

Postpaid, each 10c.; 6, 50c.; doz. 95c. Not postpaid, each $8 \mathrm{c}$; $6,45 \mathrm{c}$; doz. $80 \mathrm{c}$. $100, \$ 5.25$.

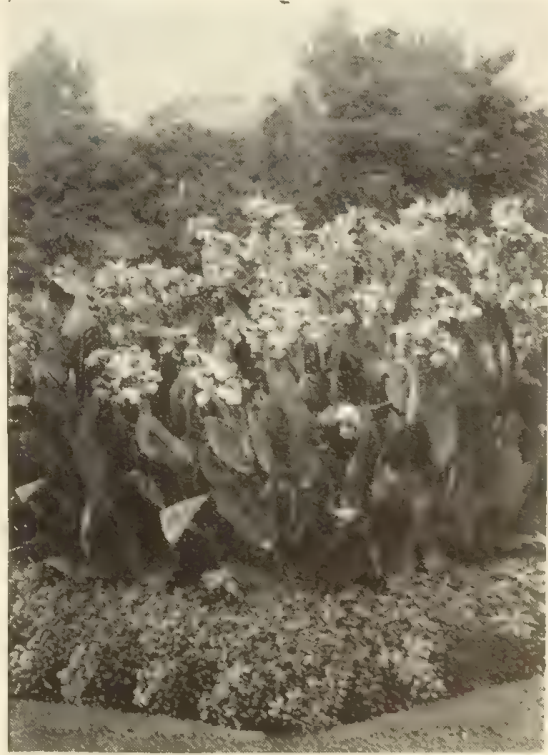

Cannas 


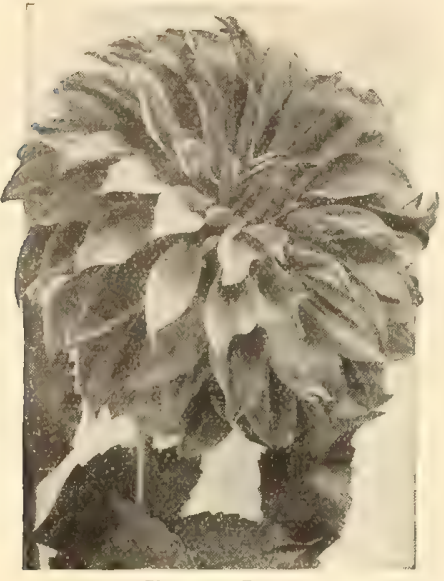

Jimmie Foxx

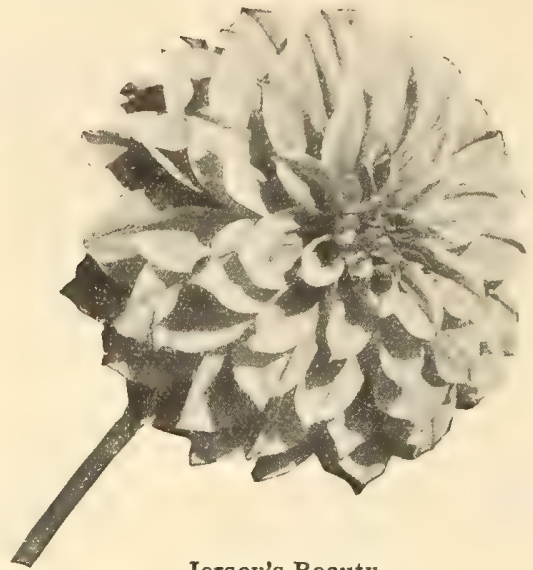

Jersey's Beauty

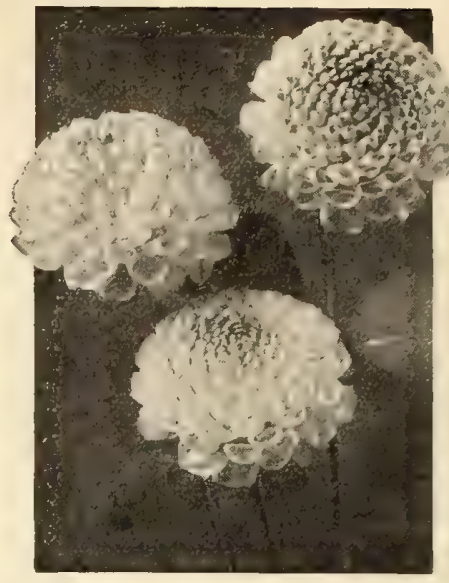

Yellow King

PRICES POSTPAID

\section{Bolgiano's Dahlias}

PRICES POSTPAID

Our Dahlias are grown under conditions that make them | proved merit. Our Annual Dahlia Show gives us a good opporvigorous. They are not overfed. They are grown in ordinary soil tunity of ascertaining what varieties appeal most to Dahlia and under conditions such as the average grower finds. Our lovers. Every tuber is guaranteed to have an eye or sprout and Dahlias GROW for our customers. We list only varieties of $\mid$ no broken neck.

Abbreviations: (F.D.) Formal Decorative, (I.D.) Informal Decorative, (Min.) Miniature, (C) Cactus, (Pom.) Pompons.

Buckeye King. (F.D.) Almost pure gold/Luella Kate. (F.D.) Lovely blend of with a slight apricot shading to center.

Clara Barton. (F.D.) A beautiful ligh lavender flower of good size. Each $50 \mathrm{c}$.

Clara Carder. (I.D.) Immense blooms of a beautiful shade of cyclamen-pink. Each $35 \mathrm{c} . ; 3, \$ 1.00$

Elissa Landi." (F.D.) Jasper blended with warm buff; brilliant orange effect. Fine stems. Each 35c.; 3, \$1.00.

Jane Cowl. (I.D.) Deep massive blooms of bronzy buff and old-gold, blending darker to center. Each 25c.; 3, 70c

Jersey's Beauzy. (F.D.) A beautiful rosepink with silvery sheen. Ideal for culting. The most popular pink. Each 25c.; 3,70c Jersey's Dainty. (S.C.) Fine white, flushied lavender. A beauty. Good keeper. Each 25c.; 3, 70c

Jimmie Foxx. (I.D.) Coppery red suffused and tinged henna. An immense Dahlia and a good one. Each 50c.

Kemp's Radiant Beauty. (F.D.) Light canary-yellow, striped and dotted scarlet. A giant. Each \$1.00.

Kentucky. (F.D.) Nice pink blended with yellow and gold. A daughter of Jersey's Beauty. Each 25c.; 3, 70c.

Larry Mart. (F.D.) Self-color of autumn amber-orange. Well formed. Each $\$ 1.00$. tinctive. Each 25c.; 3, 70c. Dahlia. Each
Good keeper. Desirable. Each \$1.00.

Mrs. I. de Ver Warner. (F.D.) An established favorite large lavender. Dis-

Omar Khayyam. (F.D.) Chinese red shading to bright orange, tipped lighter. Strong grower; sure bloomer. Each 25c. $3,70 \mathrm{c}$

ride of Stratford. (I.D.) Two-tone orange; beautiful form; good size; rich Red Jersey. (F.D.) A very fne red with growing habits of Jersey's Beauty. A fine

Royal Pennant. (F.D.) Rich purplish violet. A beautiful shade. Tall grower Santa Monica. (C) A lovely white, starshaped Cactus. Water-lily form. Fine stems; good keeper. Each 50c.

Zion's Delight. (F.D.) A good red of medium size. Free bloomer; medium growth. Each 25c.; 3, 70c.

\section{Small-flowered Varieties}

Betty Anne. (Pom.) Soft clear pink. Each 25c.; 3, 70c.
Dusky. (Min.) Dark red, almost black. Each $25 \mathrm{c}$; 3, $70 \mathrm{c}$.

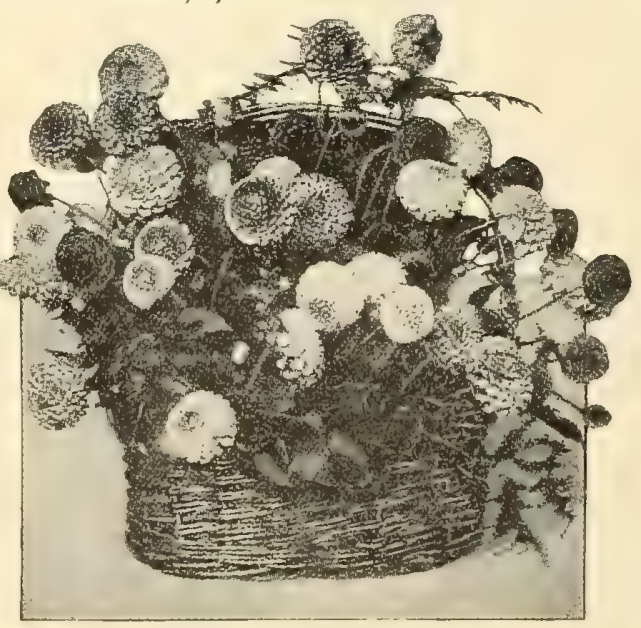

Mixed Pompon Dahlias
Little Edith. (Pom.) Primrose-yellow, tipped carmine. Each 25c.; 3, 70c.

Little Herman. (Pom.) Red and white Fancy. Each 25c.; 3, 70c.

Little Rapture. (Min.) Pink blending to rich creamy colored center. Very prolific. Each 25c.; 3, 70c.

Mirth. (Min.) Lively orange-scarlet of even color. Each 25c.; 3, 70c.

Yellow King. (Pom.) A large fine yellow Pompon. Prolific bloomer. Almost perfect ball. Each 25c.; 3, 70c.

\section{Mixed Dahlias}

All-Giant Mixture. A yery popular collection at our Dahlia Show. Includes numerous of the recent higher priced varieties, mixed in growing and handling, names lost, etc. Each 15c.; do7. \$1.50.

Mixed Dahlias. A big-value offer of many good varieties that have become mixed in handling or from which labels have been lost. For those who do not care for names this collection will be very satisfactory. Each 10c.; doz. \$1.00.

\section{Dwart Dahlias}

P. M. Mixture. Pompons and Miniatures that have gotten mixed in growing and names lost. AII good. A fine collection of these popular types. Each 10c.; doz. \$1.00.

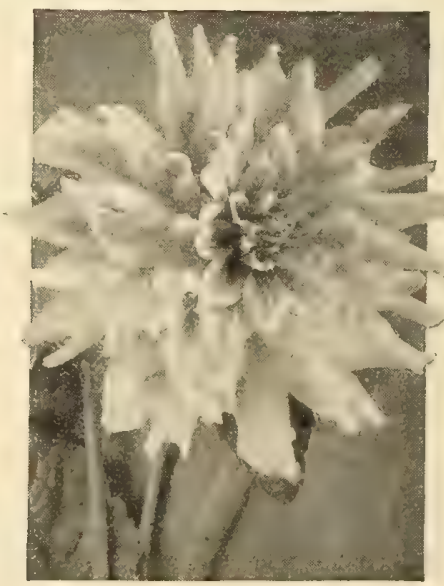

Jane Cowl 


\section{BISHOP BIRD.HOUSES, FEEDERS AND SHELTERS}
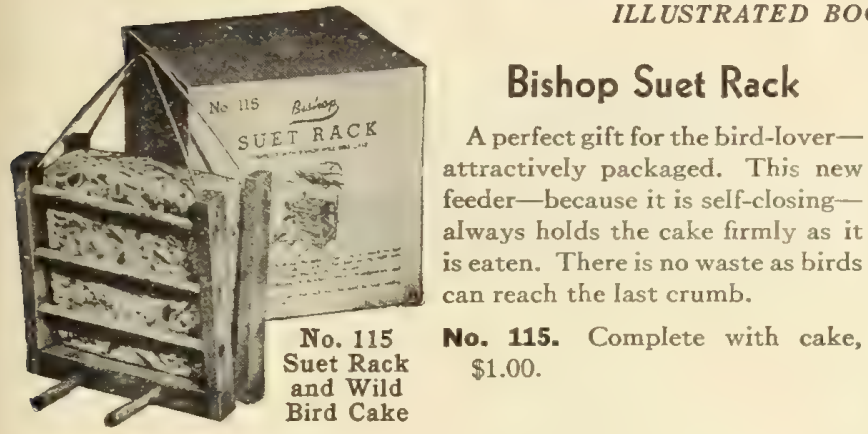

No. 115. Complete with cake, $\$ 1.00$.

\section{Bishop Wild Bird Cake}

A balanced food, in cake form, molded of pure beef suet with a dozen varieties of seeds, grains, and berries. Net weight, 12 ounces minimum. Each $30 \mathrm{c}$.; doz. $\$ 3.00$.

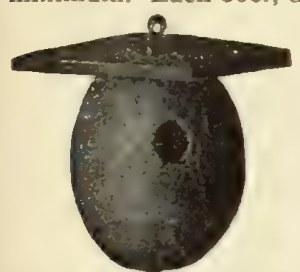

\section{Bolgiano's Special Wild Bird Feed}

Composed of sunflower seeds, peanuts, wheat, buckwheat, kaffrr corn, millet, canary seed, wild rice, hulled oats. Ask for current prices.

Bishop Coconut Wren House

No. 50. Yes, it's a genuine coconut. Unique, but thoroughly practicaI. Easily opened for cleaning. $65 \mathrm{c}$

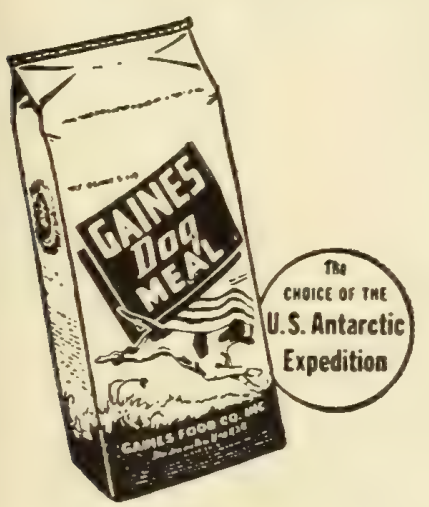

\section{Gaines Dog Food}

Gaines Meal. A complete baIanced food in granular form, with a reservoir of vitamins $A$, $B, D, E$, and $G$. Recommended for both adult dogs and puppies. 5 Ibs. $50 \mathrm{c}$; 10 lbs. $\$ 1.00 ; 25 \mathrm{lbs}$. $\$ 2.00 ; 50$ lbs. $\$ 3.75 ; 100$ lbs $\$ 6.50$.

Gaines Krunchon. Gaines meal hardened by pressure into pellet form which does not injure the precious vitamins. Thus it unites the nutritional qualities of the meal with all the advantages of a hard food. 5 lbs. $60 \mathrm{c}$. 10 lbs. $\$ 1.15 ; 25$ lbs. $\$ 2.20$ 50 Ibs. $\$ 4.10 ; 100$ Ibs. $\$ 7.25$.

\section{Bee Supplies}

KEEP BEES FOR PROFIT Ask for Free Catalog
ock-Cornered Frames

$$
\text { Wt. } 100 \quad 10 \quad 50 \quad 100
$$

Hoffman Frames. $91 / 8 \times 175 / 8$ in .......46 $\$ 0 \quad 85 \$ 3 \quad 10 \quad \$ 605$ Sh. Ext. Frames. Regular depth $53 / 8$ in...26 $\quad 60 \begin{array}{llllll}2 & 30 & 4 & 30\end{array}$ Sections $41 / 4 \times 41 / 4 \times 17 / 8$ in. Sections $4 \times 5 \times 1 \frac{3}{8}$ in.

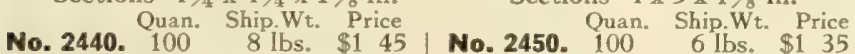
No. 2442, 500 32 lbs. 660 No. 2452. 500 29 lbs. 610 No. 2443. 1000 lbs, 1320 No. 2453. 1000 56 lbs. 1220

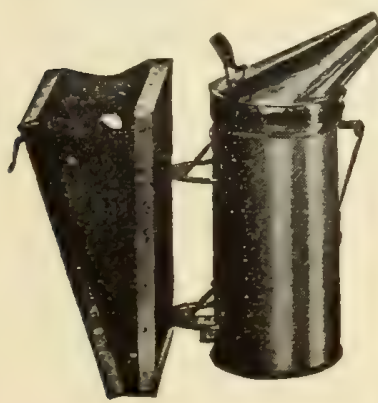

Cat. No. Quan. Ship.Wt. Price 2442S. (Split) Quan. Ship.Wt. Price 2442G. (Grooved) 50032 lbs。 705 $4 \times 5 \times 1 \frac{13}{8}$

2452S. (Split) 50029 lbs. \$6 55 2452G. (Grooved) 50029 lbs. 655 TIN SMOKERS

Standard. $3 \frac{1}{4} \times 7$ in. 2 lbs. $\$ 105$ Jumbo. $4 \times 7$ in. 3 lbs. 125 HIVE TOOLS

8 -in.............. ozs. $\$ 057$ 10 -in. ............... 65 ozs. 65 ALL PRICES SUBJECT TO

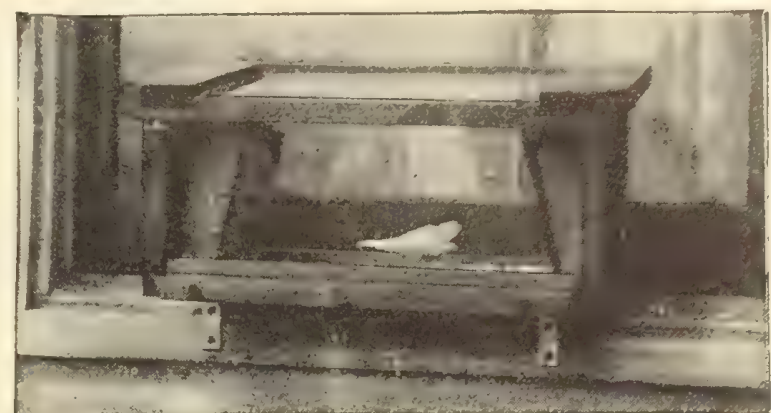

Bishop Window Feeders $\begin{gathered}\text { (Patents } \\ \text { pending) }\end{gathered}$

No. 119. Illustrated above. Fitted with hinged glass top, permitting one to care for the Feeder from within the house. Has builtin seed-hopper and suet rack. Constructed of durable cypress. Length 24 in. $\$ 5.75$.

No. 124. Same as above, but made of pine and 17 inches long. $\$ 3.50$.

Bishop Feeder complete with Wild Bird Cake

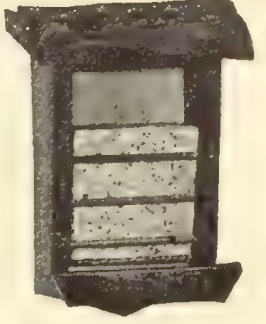

No. 101
No. 101. Attractive in appearance and attractive to the birds. Will bring many species. Height 10 in. $\$ 1.25$ complete.

\section{Bee Supplies STANDARD HIVE 10 frames, no foundation, KD}

Root Quality

Hives. Made of select, clear white
pine, the corners accurately dovetailed. The improved handholds are hollowed out to fit thefingers. Top is pressed into shape, thereby preventing all leaking. Bottom board is made of cypress. The frames are the new lockcornered frames that can be assembled faster than any others, Full directions are included with each hive.

Cat. No.

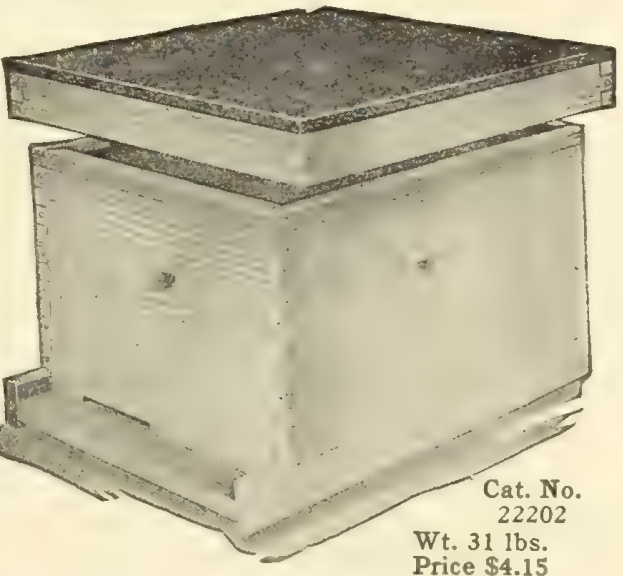

22203. Standard Hive. Mastic cover; 10

22552. Supers. For plain $4 \times 5$ sections. No

sections or foundation............ 1 KD $12 \quad 190$

22553. Supers. For plain $4 \times 5$ sections. No

22542, Supers. For beeway sections. No
25.

sections or foundation.............. 1 KD

22543

$5 \mathrm{KD} \quad 39$

Cat. No.

\section{Airco Comb Foundation}

5000. 3-ply Brood Foundation, $8 \times 16^{3} \frac{1}{4}$ in. 10 sheets. $3 \mathrm{lbs} . \$ 1$ t0

5003. 3-ply Brood Foundation, $8 \times 163 / 4$ in. 50 sheets 9 lbs. 645

5110. Single-ply Foundation. 10 sheets.......... lbs. 120

5113. Single-ply Foundation. 50 sheets..... $8 \mathrm{lbs}, 565$

5331. Thin Super Foundation. 1-lb. carton........2 lbs. 105

5333. Thin Super Foundation. 5-lb. carton.......7 lbs. +95 


\section{BOLGIANO'S BLOOD_TESTED BABY CHICKS}

\section{Bred for Constitutional Vigor and Heavy Egg Production . Strong, Healthy, Lively, Chicks} WE PAY THE POSTAGE IN FIRST, SECOND AND THIRD ZONES

S.-C. White Leghorns Barred Plymouth Rocks

New Hampshires

White Rocks

\section{VARIETY}

Rhode Island Reds

Rock-Red Broiler (Cross-Bred)

White Pekin Ducklings

Bronze Turkey Poults

\section{WRITE FOR PRICES. AS SEASON ADVANCES PRICES DECLINE}

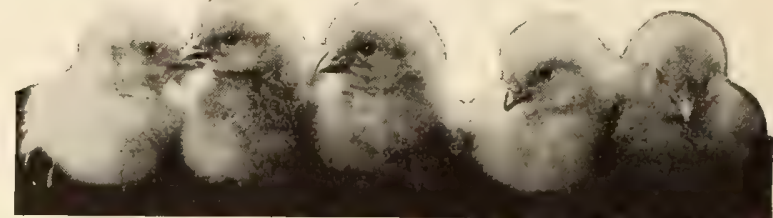

Be sure when writing us that your full name and post office is very plainly given. State plainly the number and variety of Chicks you want, when wanted, and we will acknowledge receipt of your order at once, and tell you when the Chicks will be shipped.

Cash must be sent with your order, for we cannot ship C. O. D., by Express or Parcel Post.

We guarantee to deliver 97 per cent of the Baby Chicks to you in good condition.

\section{Acidox}

An aid in the treatment of all six kinds of coccidiosis. Add 1 tablespoonful of Acidox to each gallon of clean drinking water (1 teaspoonful to each quart) every other day for two weeks. On days in between when Acidox is not used, add Germozone to the drinking water ( 2 tablespoonfuls to each gallon, 2 teaspoonfuls to each quart)

4 ozs. (enough for 100 chicks) .....\$0 50

100

32 ozs. (enough for 800 chicks)

200

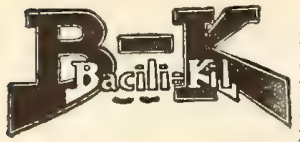

A preventive disinfectant for houses to keep your flocks healthy. A deodorant to keep brood-

ers, incubators, birds and premises clean and sanitary.

POWDER

91/2-oz. bottle..\$0 $75 \mid 13 / 4$ oz. bottle.. $\$ 150$

\section{LIQUID}

4-oz. bottle.

30 | 1 gal.

10-oz. bottle.

$50 \quad 5$ gals.

200

1-qt. bottle.

90

850

"Black Leaf" Worm Powder

$1 / 4$ Ib. (treats 100 birds) 75c.; $11 / 2$ Ibs. (treats 600 birds) $\$ 2.90$.

"Black Leaf" Worm Pellets

100 (treats 100 birds) 85c.; 500 (treats 500 birds) $\$ 3.50$

\section{Lee's Gizzard Capsule}

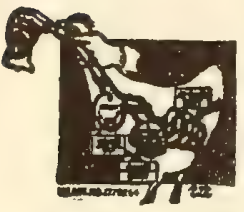

A triple combination A medicine containing Kamala (for tapeworms), nicotine sulphate (for round worms), and Py-
rethrum (for pinworms) -all in an insoluble capsule. Five times as effective as worm remedies given in food or drink.

For Adults. 50-cap. pkg. 75c.; 100-cap. pkg. \$1.25.

For Pullets. 50-cap. pkg. 50c.; 100-cap. pkg. $\$ 1.00$.

For Chicks. 50-cap. pkg. 40c.; 100-cap. pkg. $75 \mathrm{c}$.

\section{Germozone}

Germozone is a liquid which should be added to the drinking water three times a week as a safeguard against white diarrhea, coccidiosis, poisoning, digestive disorders and disease germs. 4-oz. bottle $40 \mathrm{c}$.; $12-\mathrm{oz}$. bottle $75 \mathrm{c}$.; 32 -oz bottle $\$ 1.50 ; 1 / 2$-gal. bottle $\$ 2.50$; 1 -gal. bottle $\$ 4.50$.

\section{POULTRY SUPPLIES}

\section{Group-Over Liquids for Colds}

2 ozs. 50 c.; 8 ozs. $\$ 1.00$; qt. $\$ 3.00$

\section{Bourbon Dip and Disinfectant Qt. 60c.; gal. $\$ 1.60$}

Lice Powder.

Sodium Fluoride Lice and

Roach Powder.........25c. and 50c.

Pine Oil Disinfectant... . . . . . GaI. \$2.25

Cresol Compound.

GaI. $\$ 2.25$

Creosote Oil

GaI. $\$ 1.10$

\section{Hyfex}

A concentrated coal-tar disinfectant recommended for use in disinfecting about stables, poultry houses, kennels, etc. One pint when diluted will make 50 gallons of disinfecting fluid. Pt. 90c.

\section{Pik-Rem}

An Anti-Pick Preparation for Poultry. This product is prepared from material which gives it unusual adhesive properties. It sticks permanently, and the taste and odor is repulsive to chicks and adult birds. Stops cannibalism and toe-picking. 2-oz. jar 25c.; 5-oz. jar 50c.; 12-oz. jar $\$ 1.00$.

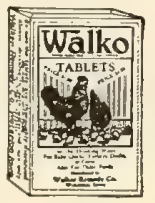

\section{Walko Tablets}

For the drinking water for baby chicks, turkeys, ducks or geese; also for older fowls. Pkgs. 50c. and $\$ 1.00$.

\section{Pratts, \\ Remedies \\ Regulators \\ Disinfectants}

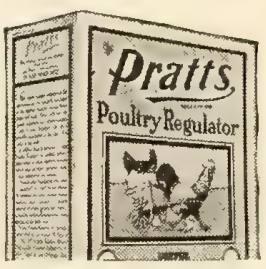

Pratt's Poultry Regulator. Guaranteed to produce more eggs in 15 days or money back. Shortens molt. Builds vitality. Keeps young birds growing like weeds. Pkgs., (18 ozs.) $25 \mathrm{c}$.; $23 / 4$ Ibs. 50 c. 6 Ibs. $\$ 1.00 ; 121 / 2$ Ibs. $\$ 1.75 ; 25$ Ibs. $\$ 3.25$.
Pratt's “Split-Action" N-K Capsules. Contain the new miracle wormer, Phenothiazine. More effective. Easier on birds. For Adults. 50 caps. 65 c.; 100 caps. $\$ 1.10$; 500 caps. $\$ 5.00$

For Pullets. 50 caps. 45 c.; 100 caps. 75 c.; 500 caps. $\$ 3.75 ; 1000$ caps. $\$ 6.50$.

Worm Powder. Round worm flock treatment for use in mash. Easy, quick, effective. 100-hen pkg. 75c

R-P Tablets. Formerly called Roup Tablets. For use in drinking water of adult birds. Guaranteed. 30c. and $60 \mathrm{c}$.

Chick Tablets. Use in drinking water. Saves chicks. Gives all-day protectionnot just a few hours. $30 \mathrm{c}$. and $60 \mathrm{c}$.

Pik-No-Mor. Stop cannibalism among chickens of all ages. $30 \mathrm{c}$. and $60 \mathrm{c}$.

Poultry Inhalant. For better control of colds and catarrh in poultry. Pt. 70c.; qt. $\$ 1.25$.

\section{Kill Lice - this Easy Way}

Pratt's Roost Paint. Kills lice. 2 ozs. $40 \mathrm{c}$. $1 / 2$ pt. $\$ 1.00$; pt. $\$ 1.75$; qt. $\$ 2.50$; gal. $\$ 7.50$.

Powdered Lice Killer. In sifter cans for use in dust-baths, nests, etc. $30 \mathrm{c}$. and $60 \mathrm{c}$.

Animal Regulator. Keeps stock in the pink of condition. Contains "trace elements" and vitamin D. Lb. 25c.; $21 / 2$ lbs. 50c.; 6 Ibs. $\$ 1.00 ; 25$ Ibs. $\$ 3.50$.

Zene-a-Trol (Phenothiazine Powder). Effective worm treatment for turkeys, hogs, sheep and horses. 1/2-lb. pkg. \$1.00; 1-lb. pkg. $\$ 1.50$.

Cow Tonic. An appetizer, tonic and mineral supplement fordairy cows and calves. 60c.

Hog Powder. Minerals ... Trace Elements . Vitamin D... Tonics... all in one. $25 \mathrm{c}$. and $50 \mathrm{c}$

Pratt's Disinfectant. For dipping and spraying poultry and stock. Pt. 40c.; qt. $60 \mathrm{c}$; gal. $\$ 1.60 ; 5$ gals. $\$ 6.50$.

Pratt's C-Ka-Gene. Stops heavy Iosses from bloody coccidiosis. Turns natural attacks into immunity (permanent protection). 50-chick pkg. 75c.; 100-chick pkg. $\$ 1.25 ; 250$-chick pkg. $\$ 2.75$.

Pratt's Baby Chick Starter. Write for prices.

Ask for FREE Poultry and Livestock Health Guides

\section{Poultry and Bird-Feeds}

Bolgiano is headquarters for all kinds of Poultry and Bird-Feeds including Alfalfa Meal, Scratch Feed, Chick Grains, Poultry Mash Feed, Crushed Oyster Shells, Charcoal, Cracked Bone, Dried Buttermilk and Seeds for Pigeons, Parrots and Canaries. Prices on request. 


\section{POULTRY SUPPLIES, continued}

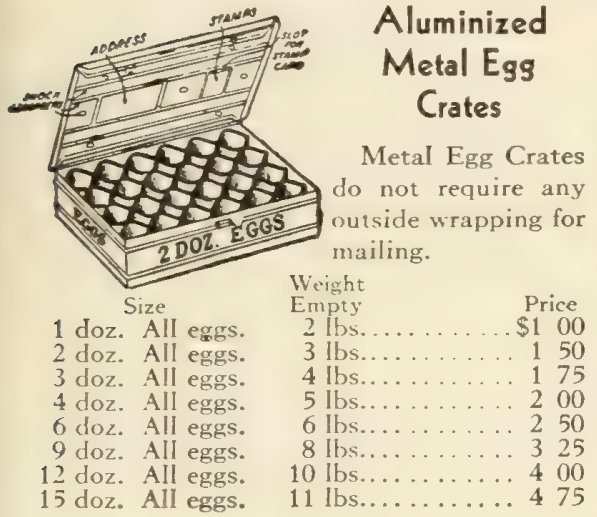

Humpty Dumpty Folding Egg Crates
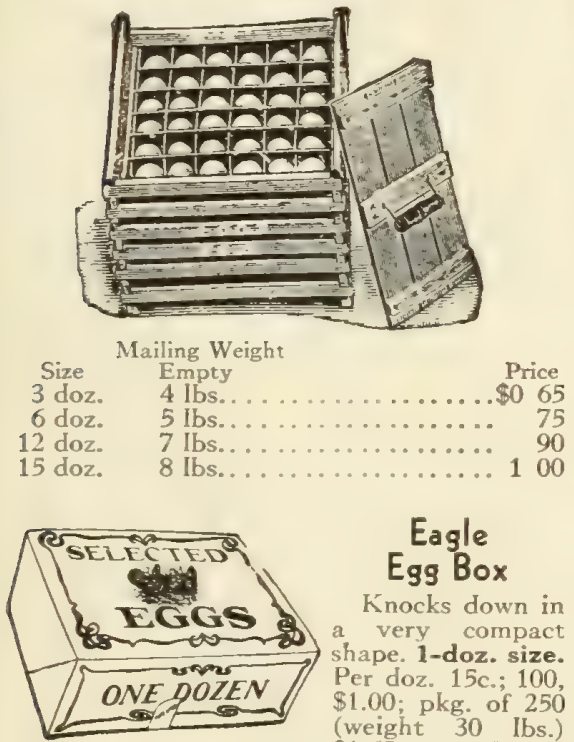

Eagle

Egs Box

Knocks down in a very compact shape. 1-doz. size. Per doz. 15c.; 100 $\$ 1.00$; pkg. of 250 (weight 30 lbs.)

Egg Case Fillers

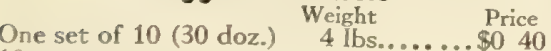
10 sets

$50 \mathrm{Ibs} \ldots \ldots . . .350$

\section{Cyclone's New Double Dial} Egg Scale

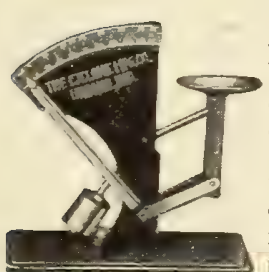

There are no springs -nothing to wear out The dial is set out. angle for easy reading and shows both the weight per dozen and the actual weight of the egg. Attractively frnished and carefully 5805. Scale with Automatic Stop. $\$ 1.50$.

Graded Eggs Means a Higher Market Value

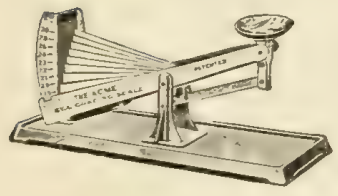

Acme Scales

$\$ 2.50$.

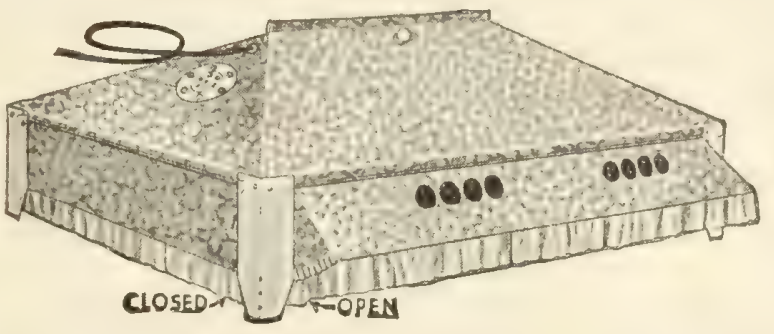

No. 175. $34 \times 34$ in., 200 chicks. Weight, 25 lbs., less bulbs. \$6.25.

No. 175A. $34 \times 34$ in., 200 chicks. Weight, 26 lbs.,

No. 300. $44 \times 52$ in., 300 chicks. Weight, 85 Ibs., No. 500. $54 \times 66$ in., 500 chicks. Weight, 120 Ibs., automatic. $\$ 35.50$.

E-Con-O Brooder. Provides abundant warmth for up to 150-day-old chicks. (Use one 100-watt electric bulb.) The $32 \times 32$-in. hover is made of strong fiber-board having desirable insulating properties equal to that of cork. Top of hover is coated with an attractive aluminum finish. Legs and deflector are of galvanized metal. Porcelain socket has protected top and 5 feet of cord is furnished. Muslin cloth curtain is stapled in our plant to sides of hover. Bulb is not furnished. The brooder is sturdy and attractive. $\$ 2.50$.

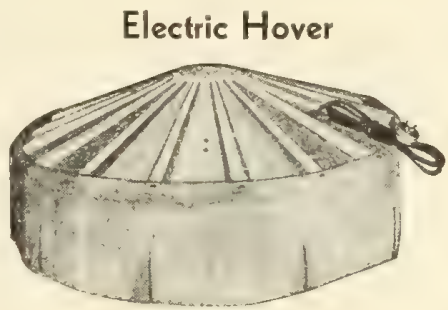

No. 86. 24-in. diam. Capacity 25 to 50 chicks. Complete with curtain, 6 feet of cord. No bulb furnished, as any ordinary light bulb will do. Weight, 8 lbs. $\$ 2.50$.

Violet Light Bulb, 75c.

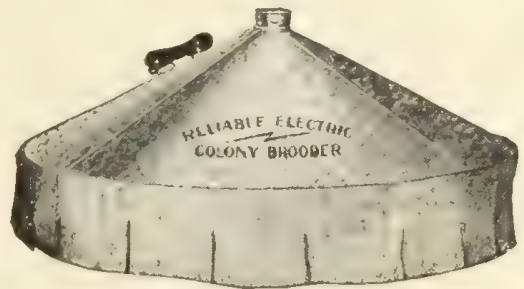

No. 89. Reliable. 52-in. canopy. 500 watt. Weight 48 lbs., Automatic. $\$ 18.50$.

\section{SOL라이누}

Oil-Burning Brooders

Efficient and Economical

Complete with automatic control

No. A1235. 35-in. canopy. Capacity 200 chicks. 4-in. burner. Weight 27 Ibs, $\$ 10.00$.

No. A1255. 55-in. canopy. Capacity 500 chicks. 53/8-in. burner. Weight, 40 lbs. $\$ 13.00$.

\section{Oil Drum Brooder}

No. 2146. The Commander. 46-in. canopy. Capacity up to 1000 chicks. $21 \times 8$-in. drum. 8-gal. oil-tank. Shipping weight $\$ 16.50$.

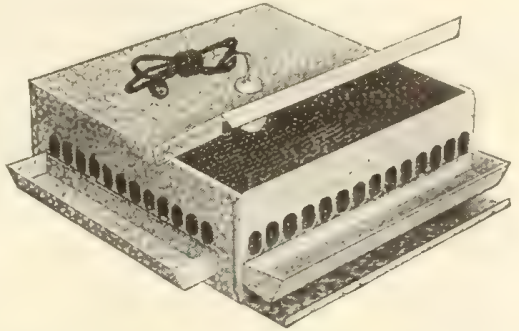

No. 55. All-metal construction, with removable mesh floor and metal clean-out tray. Very sanitary and easy to clean. Any 60 -watt light bulb can be used for heating but the Violet Light Bulb (75c.) is recommended. Six feet of cord supplied. 110 volt. $20 \times 20$ in., 50 chicks. Weight, 15 lbs. Less bulb, $\$ 3.50$

\section{Liv-an-Grow Brooders}

Similar to above; cardboard box. Weight, 6 Ibs. Less bullb, $\$ 2.50$.

Violet Light Pilot Bulb for above Brooders, 75 c. extra.

Shenandoah Air-conditioned Electric Brooder

No. 50. Diam. of hover, 50 in. Capacity up to 300 chicks. Complete $\$ 34.50$.

Shenandoah Time-Tested Wood-

Burning Brooders

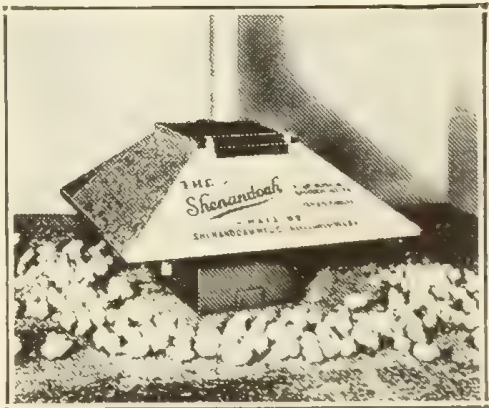

No, 24. For $10 \times 10-f$. brooder rooms or larger and for winter brooding. Fuel capacity: $5.6 \mathrm{cu} . \mathrm{ft}$. Size of hover, $51 \times 51$ door, as illustrated, $\$ 25.00$.

\section{Coal Brooders}

500-chick, 42-in. canopy ............... 1000-chick, 52-in. canopy...............21 2150 Roof Saddle Flange Pipe, 5-in., with

Revolving $\mathrm{Rain}$ Cap.

ALL PRICES SUBJECT TO CHANGE WITHOUT NOTICE 


\section{POULTRY SUPPLIES, continued}

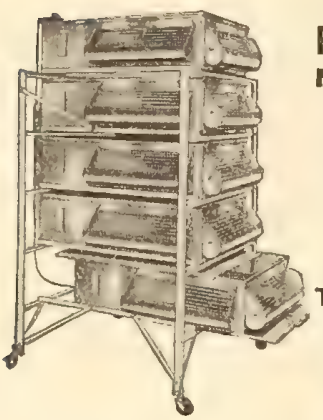

Electric Egg Tester

No. 700. Here is an Electric Egg Tester that will save time. It is durable, strong, very accurate, and easy to use. $\$ 1.50$.
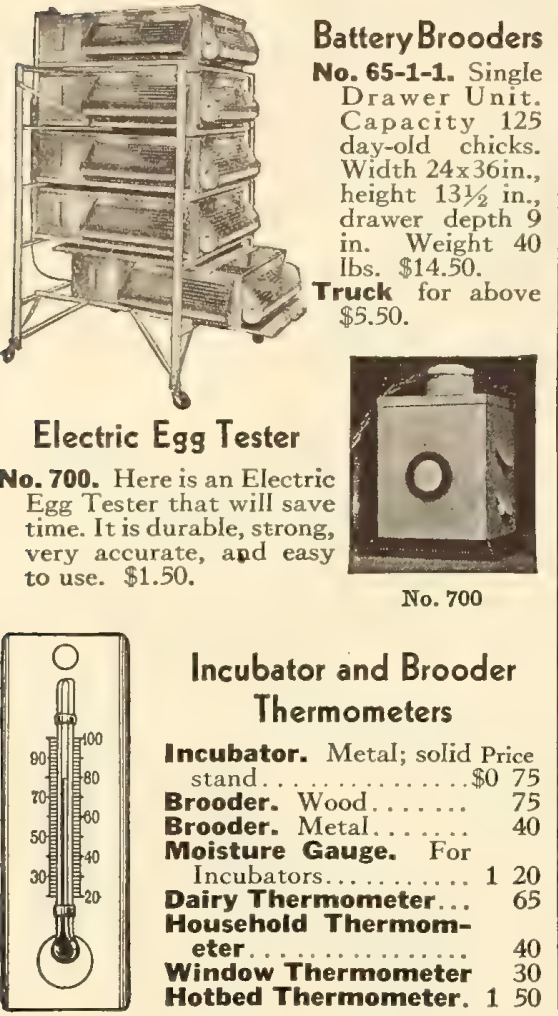

Incubator and Brooder Thermometers

Incubator. Metal; solid Price stand............ \$0 75 Brooder. Metal........ 40 Moisture Gauge. 'For

Incubators........... 120

40

Household Thermom-

eter.

Window Thermometer 30 Hotbed Thermometer. 150

\section{Reliable Brass Wafer Thermostats} for Any Incubator or Brooder

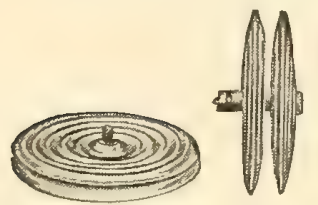

3-in.

$4-$ in

5-in.
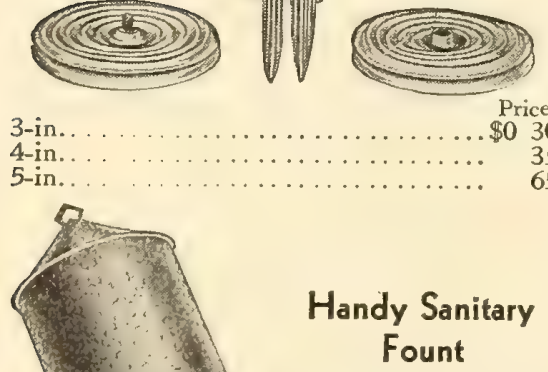

No. 303. 3-gal. Weight 6 Ibs. $\$ 1.85$.

No. 505. 5-gal. Weight $14 \mathrm{lbs}$. $\$ 3.00$.

No. 308. 8-gal. Weight 16 Ibs. $\$ 3.50$.

Stands. $25 \mathrm{c}$.

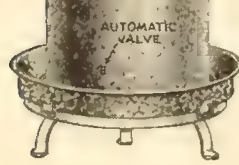

\section{Electric Heater}

Needs no attention-safe and economical. Cost averages about 3 cents a day. Can be used with any type fountain, pan or bucket. Extra eggs soon pay for this wonderful Heater. Mailing weight, 2 lbs. $\$ 3.85$.

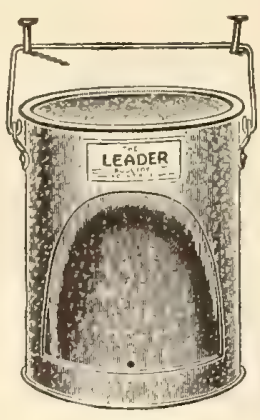

Reliable Float Valve

A perfect

matic Valve and brass Float for regulating the flow of water in drinking-pan or trough.

It is made of brass with a brass Float.

This Valve may be adjusted to bring water-level to the height desired. It is threaded for $1 / 2$-inch iron pipe thread. Pan is not furnished. $\$ 1.00$.

\section{Fountain, Heater and Stand}

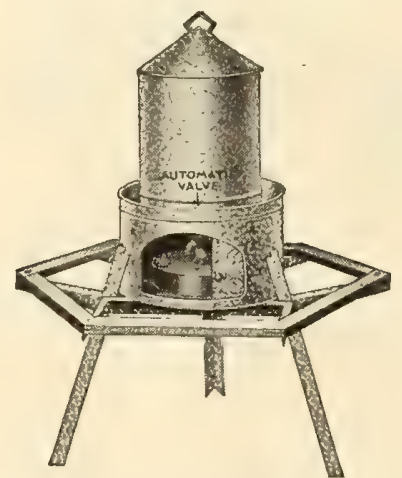

Heater and Stand are all made of heavy galvanized iron. Weight, 18 Ibs.

The Heater is of the open-top type with a hinged door on side so that the lamp can be taken out for trimming of wick or refilling. Furnished with No. 2 burner. 5-gal. size, $\$ 2.50$.

No. 70. The Stand is well worth this extra cost, as it places the water up off the floor, providing more valuable scratching space, also prevents litter from being scratched into the drinking water. Weight, 20 Ibs. $\$ 1.65$.

5-gaI. Fountain, $\$ 3.00$; complete, $\$ 7.15$.

8 -gal. Fountain, complete, $\$ 7.65$.

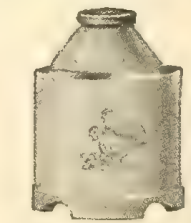

\section{Stoneware Fountains} and Milk Feeders

Made of best quality stoneware nicely glazed inside and outside. Three large openings for feeding buttermilk or sour milk to

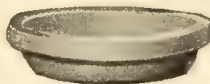
chicks. as they do not carry well.

do not send these

1 qt.........\$0 $45 \mid 4$ qts.......\$\$ Price

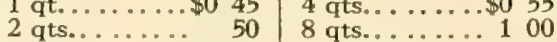

\section{Two-Piece \\ Clean-Out \\ Fountains \\ Top section slides into bottom sec- tion. The latest and most practical Sanitary Fountain on the market.}

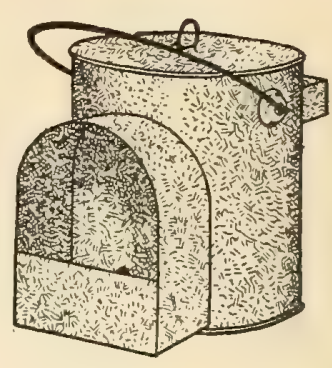

Capacity Mailing weight

Price

No. 210. 4 qts. 3 Ibs. Single mouth. $\$ 130$

No. 212. 8 qts. 4 lbs. Single mouth. 160

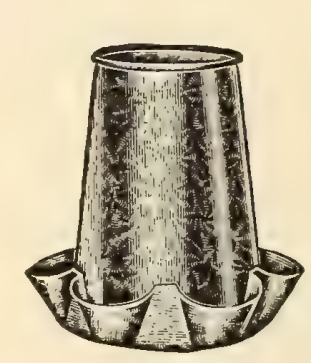

Bottom-Fill Cone Fountain

Mailing weight 2 lbs. $40 \mathrm{c}$.

\section{Fountain and Feeders}
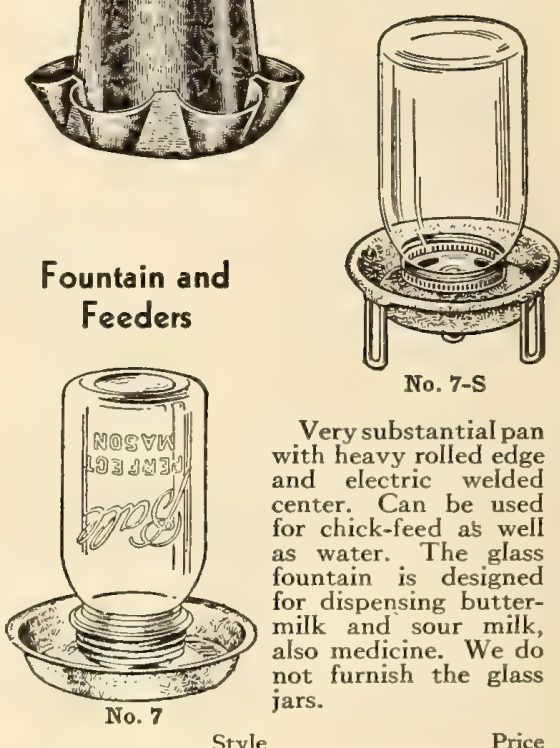

No. 7-S

Very substantial pan with heavy rolled edge and electric welded center. Can be used for chick-feed as well as water. The glass fountain is designed for dispensing buttermilk and sour milk, also medicine. We do not furnish the glass jars.

Style

Price

No. 7-S. Stand-Built Jar Founts.... . \$0 10 No. 007. Glass.................. 10

No. 7. Galvanized............... 10

\section{Little Putnam Oil Heater}

Used under the drinking vessel in poultry house to keep the water from freezing during the winter months.

Brooder Heater. For 25 chicks. Mailing weight 5 lbs. $\$ 4.75$.

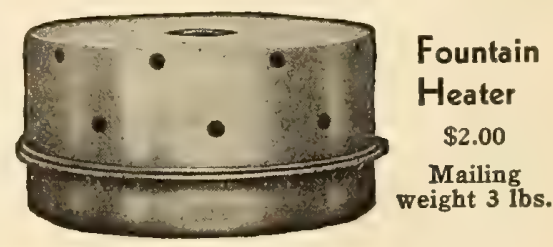




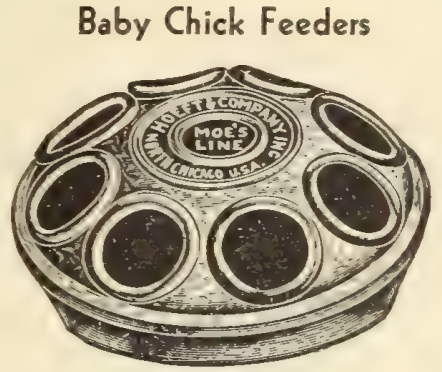

No. 6.

6 holes...

Price

No. 11C. 8 holes.

No. 12C. 12 holes.

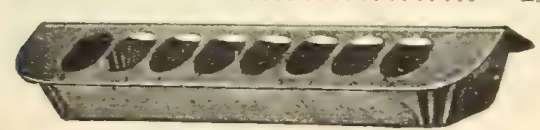

Slide-Top Chick Feeders.

11 in. Mailing weight 1 lb.

.$\$ 015$

21 in. Mailing weight 2 lbs.

25

\section{Wood Reel}

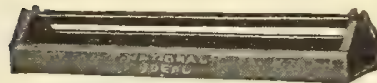

Galvanized iron Chick Feeder, 2 in. deep, 4 in. wide, square bottom set-in ends. Edge of Feeder turned in to prevent feed waste.

No. 25. 24 in. Weight $11 / 2$ Ibs.......\$0 40 No. 236. 36 in. Weight 2 lbs..... 50

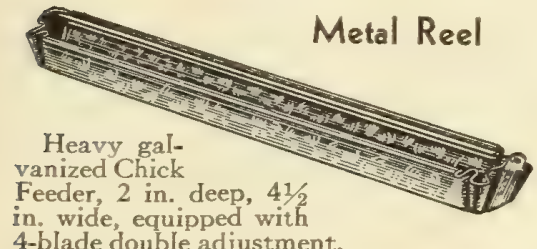

4-blade double adjustment.

No. 412. 12 in...............\$0 15

No. 424. 24 in. Weight 2 lbs.... 30

No. 436. 36 in. Weight $21 / 2$ Ibs...... 40

Hinged Grill

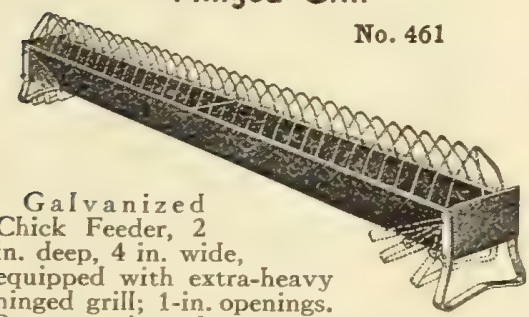

hinged grill; 1-in.

Strong set-in ends.

No. 224. 24 in. Weight 2 lbs.........\$0 60

No. 246. 36 in. Weight 21/ Ibs.... 85

No. 248. 48 in. Weight 4 Ibs........ 100

No. 461. Flock Feeder. $5 \mathrm{ft}$. Iong,

$4 \mathrm{in}$. deep, $61 / 2$ in. wide. Iron legs. . 265

\section{Water Glass}

Water Glass for preserving eggs; will keep fresh for months. One pint is sufficient for 8 dozen eggs. Pt. 20c. (mailing weight 2 lbs.) qt. $35 \mathrm{c}$. (mailing weight 4 lbs.); gal. $\$ 1.15$ (mailing weight 13 Ibs.).

\section{"Good Luck" Poultry Litter}

Large bale. Covering capacity, 80 sq. ft. 3 in. deep. $\$ 4.00$.
Hinged Grill

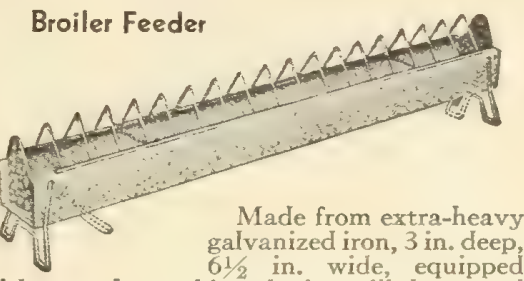

with extra-heavy hinged wire grill, Iacquered red, with $1 \frac{3}{4}$-in. openings.

Price
$\$ 110$

No. 136. Grill Feeder. 36 in..

No. 148R. Metal Reel Broiler Feeder. 48 in. .

No. 481. Hinged Grill Broiler Feeder. 125 48 in.......

\section{Longfellow Feeder}

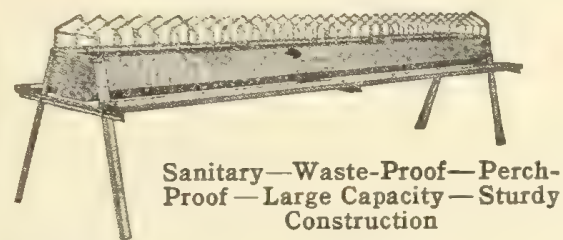

No. 405. The legs, of sturdy $1 / 8$-inch angleiron, support the Feeder 18 inches above the ground, which gives the fowls use of entire space under feeder. Perches are constructed in one piece, of $1 \times 3$-in. " $A$ " quality lumber and are strong enough to support the weight of a full-grown person. Length $5 \mathrm{ft}$. Capacity $11 / 2$ bus. Feeding space approximately $10 \mathrm{ft}$. Shipping weight 57 lbs. $\$ 4.50$.

\section{Round Grill Waterer and Feeder}

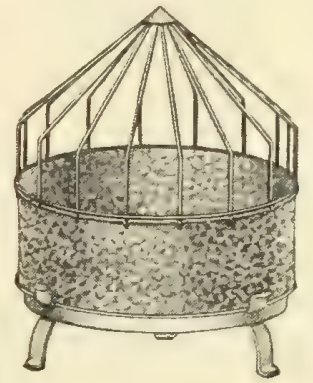

With Hi-Lo

Stand

No. 39. Ideal for feeding table scraps. As illustrated. Diam. 14 in. Capacity 3 gals. Shipping weight 7 Ibs. $\$ 1.65$.

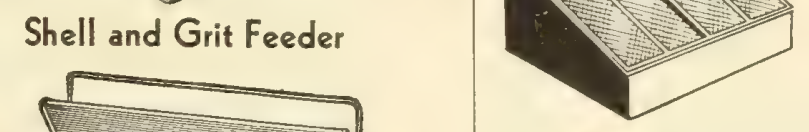

\section{Cel-O-Glass}

Reinf orced With Wire

The real glass substitute for poultry-houses, chicken-coops, barns,
hotbeds, etc. It is flexible, can be bent double, creased and then opened flat again without the slightest damage. Tack it on as you would wire netting. Admits ultra-violet rays of the sun which are very essential. Sq. $\mathrm{ft} .15 \mathrm{c}$. Rolls of 25,50 , and $100 \mathrm{ft}$., 24 and $36 \mathrm{in}$. wide, sq. ft. $131 / 2 \mathrm{c}$.

\section{Vitapane}

The new scientific and modern glass substitute for poultry-house fronts, brooderhouse windows, basement and attic windows cold and hotbed frames, barn windows and partitions. Full roll, $50 \mathrm{ft}$., 36 in. wide, $\$ 8.75$; ess than roll, sq. $\mathrm{ft} .10 \mathrm{c}$.

\section{Kow-Kare}

Will hold one, two or three kinds of feed at the same time.

$$
\begin{aligned}
& \begin{array}{l}
\text { No. Compart- } \\
\text { ments } \\
\text { weight }
\end{array} \\
& \text { No. 310. } 3 \quad 3 \text { lbs. .......\$0 } 90
\end{aligned}
$$
4 lbs.
150 


\section{FARM, GARDEN and LAWN TOOLS}

The present emergency has made it necessary for manufacturers either to discontinue or curtail items on pages 58 to 67 inclusive.

THEREFORE ALL LISTINGS ARE SUBJECT TO STOCK ON HAND

PLANET JR. FARM and GARDEN TOOLS

No. 4 Planet Jr. Combined Hill and

Drill Seeder, Wheel Hoe, Cultivator and Plow

Complete, $\$ 21.00$

Weight, $50 \mathrm{lbs}$.

As a Seeder only

(No. 4D), \$16.75

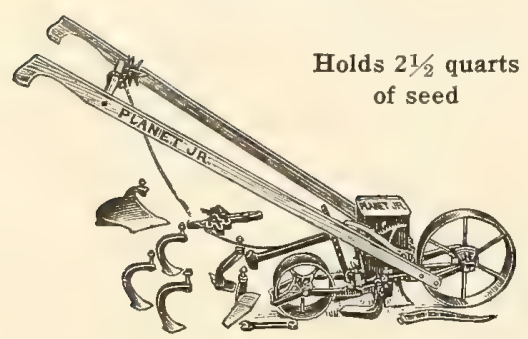

As a Seeder, the No. 4 plants almost all vegetable seeds in continuous rows or in hills $4,6,8,12$ or 24 inches apart. The furrow is opened, seeds dropped, covered and the soil frrmed and the next row marked out all in the same operation. Converted into a Single Wheel Hoe by changing one bolt. Cultivating equipment includes the most useful attachments for gardening, a plow, hoes and cultivator teeth.

No. 9 Planet Jr. Horse Hoe $\$ 15.50$

No. 9D, Without Wheel $\$ 13.75$

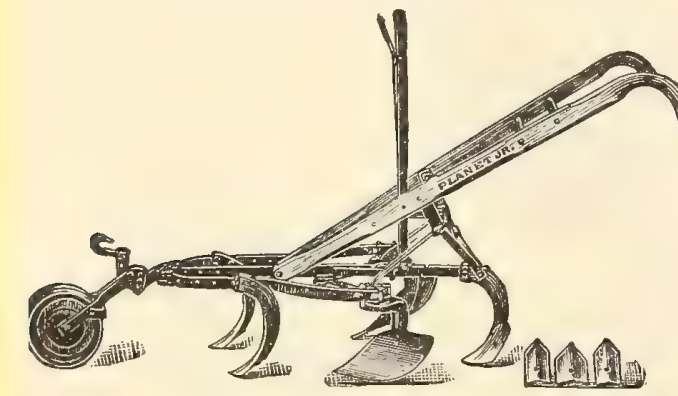

Completely equipped Horse Hoe, light weight, straight running, and easily handled. Cultivator teeth are of high carbon beveled steel, thereby making them self-sharpening, and the point retains its shape, greatly prolonging the life of the steel. Patent hillers are reversible for hoeing or hilling. Can be run close to the plants without endangering the roots.

\section{No. 101D Planet Jr. Cultivator $\$ 9.50$}

No. 1000. Same as above less the lever expander. $\$ 8.25$.

ALL PRICES SUBJECT TO CHANGE WITHOUT NOTICE
Planet Jr. No. 230 Fertilizer Distributor

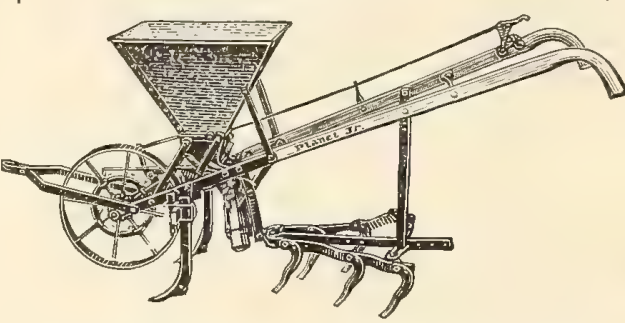

A new and highly recommended method of applying fertilizer to growing crops is to distribute it uniformly on the ground between the rows and to then cultivate it thoroughly into the soil. This insures all the feeder roots growing in the middle of the row getting their share of food. Cultivator closes to 12 inches; opens to 21 . $\$ 45.50$.

No. 300A Planet Jr. Drill Seeder

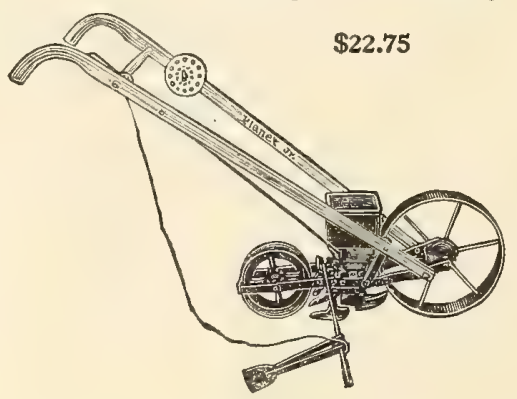

The No. 300A is rapidly becoming the most popular Seeder for market gardeners. It is a plate Seeder having three seeding plates each with 13 holes giving ample adjustment for any size seed. Adjustments quickly and easily made. Hopper removable. Many exclusive features combine to make the No. $300 \mathrm{~A}$ easy running, dependable and accurate.

No:17 Planet Jr. Single-Wheel Hoe

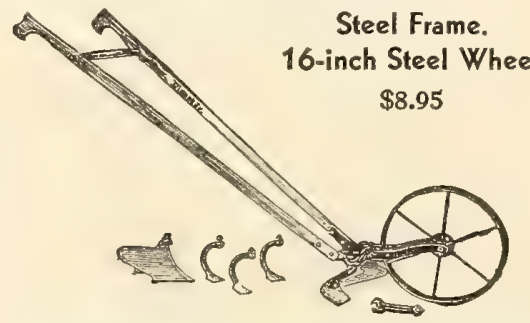

Very popular because equipment includes just the attachments needed in the average garden. A pair of 6 -inch hoes for weeding and shallow cultivation, three cultivator teeth for deeper and general cultivation and a plow with landside for hilling, furrowing, ridging and plowing. Light and easy to handle. All steel-unbreakable.

171/2 Planet Jr. Same as above less the plow. \$7.95.
No. 12 Planet Jr. Double and SingleWheel Hoe

Steel Frames. 14-inch Steel Wheels $\$ 12.95$

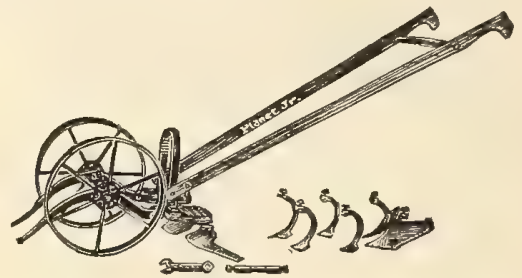

Equipment includes attachments needed in the average garden. One pair 6-inch hoes for shallow cultivation and weeding four cultivator teeth for deeper and general cultivation and a pair of plows for plowing, furrowing and ridging and a pair of leaf lifters which are useful in protecting the leaves and vines when crops are maturing. As a Double Wheel Hoe it will straddle crops 20 inches high, cultivating both sides at once. Easily changed to a Single Wheel Hoe for working between rows. Made entirely of steel and practically indestructible.

No. 11 Planet Jr. Same as above with the addition of 1 pr. $41 / 2$ in. hoes, 1 pr. 3-tooth rakes, and 1 pr. 5-tooth rakes. $\$ 16.50$.

\section{RIVAL HAND GARDEN PLOWS}

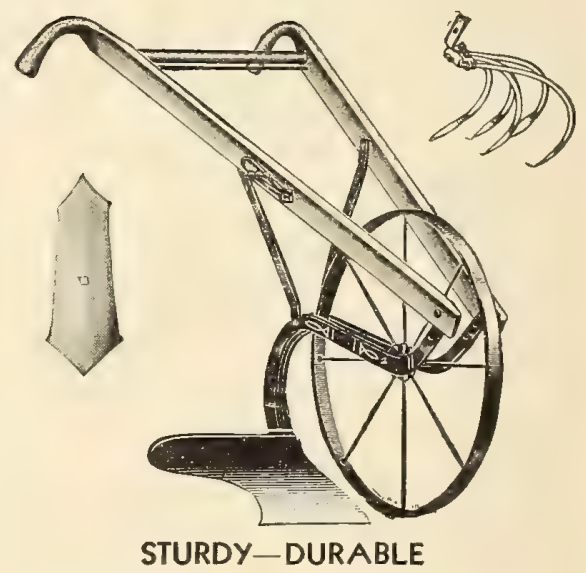

There has always been a demand for a small sturdy Garden Plow moderately priced, making it possible for the small gardener to purchase. These Plows have all the tools or parts necessary to the perfect working of a garden-for instance, it has a Plow for hilling and working the garden early in the spring; it has a cultivator and a hoe; also a pulverizing rake. It is complete in every detail. We have sold them by the hundred to pleased customers. Weight, about 20 lbs. Every garden should have one. $\$ 3.60$. 
McCormick-Deering Mowers

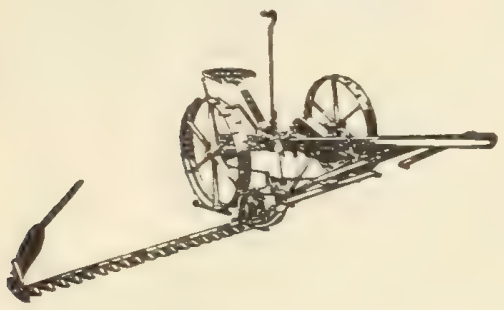

Are strong, light-running machines having a world-wide reputation for light draft, efficiency and durability.

$31 / 2$-ft. cut, McCormick only, One-

horse Vertical lift. ... \$88 50 5-ft. cut. Two-horse. Regular lift.....107 50 5-ft. cut. Two-horse. Vertical lift. . . . 10850

\section{Mower Knife Grinders $\$ 5.75$}

\section{MeCormick-Deering Self-Dump Hay Rakes}

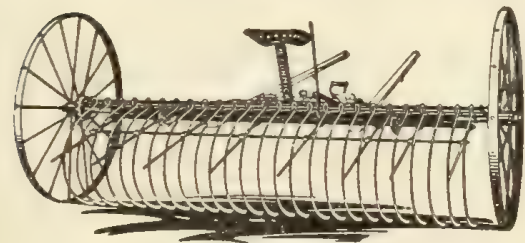

The self-dump feature is properly designed and never fails to work. All the operator has to do is to press a small foot-lever and the horses do the rest.

$8 \mathrm{ft} \ldots \ldots \ldots \ldots \$ 4650 \mid 10 \mathrm{ft} . \ldots \ldots \ldots 5175$ $9 \mathrm{ft} \ldots .5950$

Side Delivery Rake and Tedder. $\$ 124.00$.

\section{"U" Bar Lever Steel Harrow}

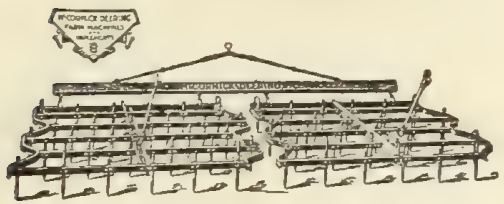

So arranged that the teeth cannot track This Harrow has a steel frame, with bars of U-shaped steel well braced and securely fastened at each end of the frame. This gives the Harrow a double advantage, strength and rigidity, and is a guard against catching into trees and stumps. The teeth can be set to any pitch or cut desired.

25-tooth, without Drawbar.........\$8 65

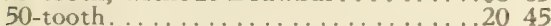

\section{Spring-Tooth Harrows}

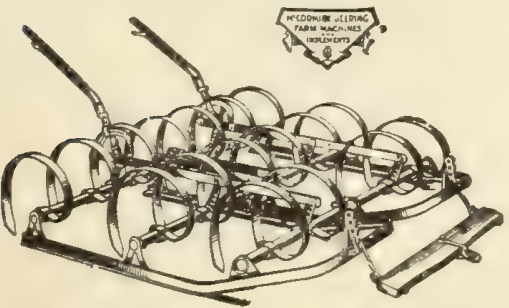

15-tooth

2800

17-iooth
Disc Harrow

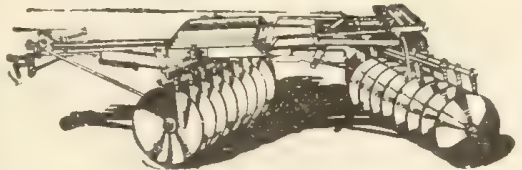

The time is long past when a farmer or market gardener can do without a Disc Harrow. When your ground is weedy and lumpy, then is the time when you need and want a Disc Harrow. They are strong, vet not too heavy; easy on horse and man; save labor-that means, save money; does the work better than it is possible to do it with a plow or any other Harrow

5-ft. Double Disc Tractor Harrow, $\$ 96.75$

6-ft. Double Disc Tractor Harrow, $\$ 105.00$

Horse-drawn Harrow, 8 16-in. discs, $\$ 56.25$.

Horse-drawn Harrow, 10 16-in. dises, $\$ 60.00$.

Horse-drawn Harrow, 12 16-in discs, $\$ 65.50$.

The above prices include Forecarriage, but without Tongue. If Tongue is wanted and not Forecarriage, deduct $\$ 9.25$.

\section{So-Rite Lime Spreaders}

The bottom is made of heavy sheet steel properly designed. A heavy sheet steel feed plate working in keepers forms the feeding device. There are punched in the bottom and feed plate 20 round holes or outlets, 2 inches in diameter, through which the material passes to the scattering board. These holes are $45 / 8$ inches apart from center to center, and extra plates can be furnished for sowing in rows. Capacity, 10 bus. Sowing swath, $8 \mathrm{ft}$., $\$ 66.50$.

McCormick-Deering Double Agitator Lime Spreader. $\$ 102.50$.

\section{McCormick-Deering Manure Spreaders}

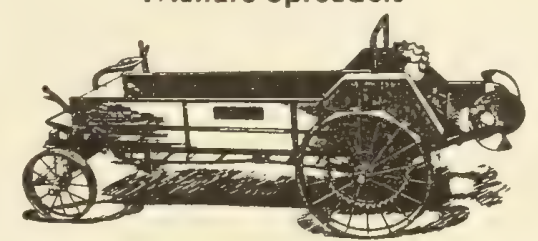

No. 200H. This Manure Spreader is an outstanding achievement in Spreader construction and has no equal in performance. It is simple, compact. Capacity of 60 to 70 bushels. $\$ 190.00$.

\section{McCormick-Deering Fertilizer Distributor}

Distributes evenly 10 to 2350 pounds per acre; instantly adiustable; force feed; light draft; durable construction. Easily cleaned. Convenient height. 9-ft. width, $\$ 110.00$.

Cole "Labor-Saver" Plow and Fertilizer Distributors

No. 60. One-horse ..........\$2300

All-Purpose Steel Wheel Truck Roller Bearing

Tractor Hitch.

ALL PRICES SUBJECT TO CHANGE WITHOUT NOTICE

Our Handy Steel Wheel Farm Trucks

Wood Hounds, Well Braced. Hickory Axles

All wood parts hardwood and well painted with grooved tire. $\$ 59.50$.

\section{Wagons}

N23. 2-horse farm. Medium Weber $\$ 14200$ N24. 2-horse farm. Standard..... 15200 N332. 1-horse. Medium. 2-inch tire. 8000 Box brake extra, 2-horse........ 1240 1-horse.

\section{Lever Feed Cutter}

Simple, durable, and reasonably priced. It has an 11-inch tempered curved knife which can be adjusted to take up the wear, thus giving a perfect shear-cut at all times. $\$ 8.00$.

\section{McCormick-Deering Farmall} Tractors

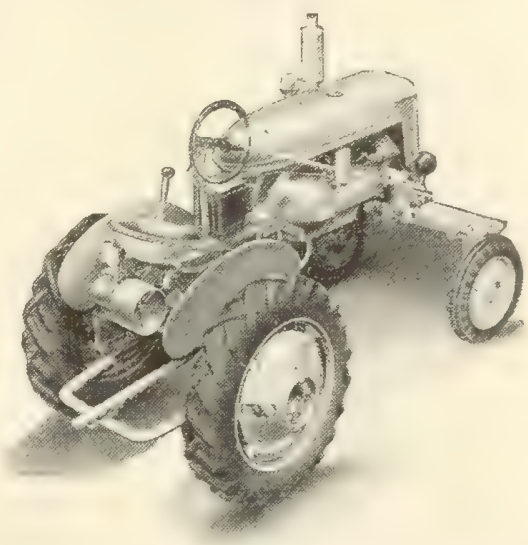

A new improved line of Farmall Tractors. Powerful and sturdy; plows, harrows, cultivates and does other jobs with only one operator. The most dependable Tractor you can buy at any price.

Model A with Culti-Vision WRITE FOR Model $\mathbf{H}$ Model $\mathbf{M}$ PRICES

Write for literature and prices of attachments

\section{Bolen's Garden Tractor}

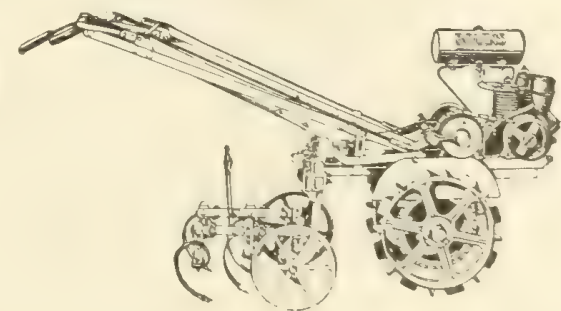

A rugged, compact and extremely flexible service unit. Always ready for any jobgarden-plowing, seed-bed preparation, seed ing, close weeding, cultivating (narrow or wide), mulching, spraying or crop-harvesting Likewise adaptable to lawn-mowing and a variety of belt work.

Power Hoe with Cultivator Frame

Super Husky Hoe

Model B6A (less Tools

Model 9EZ (less Tools

Write for complete prices and demonstration 


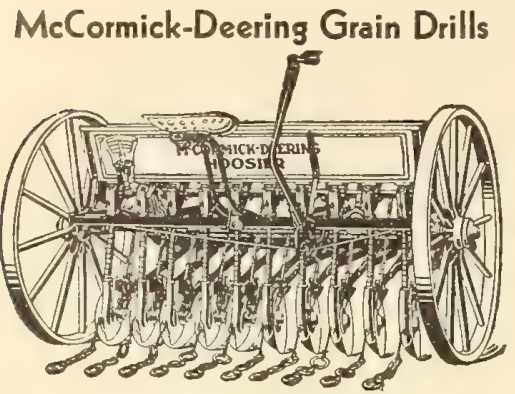

The fluted force is designed to sow surely and evenly whatever seed is being sown The fertilizer mechanism will sow 30 to 1135 pounds to the acre.

9-7 Single Dise.

11-7 Single Disc.

$\$ 16925$

Prices of other models on application.

\section{Double-Row Corn Planter}

All Planters fitted with adjustable drop plates when so ordered. Write for prices.

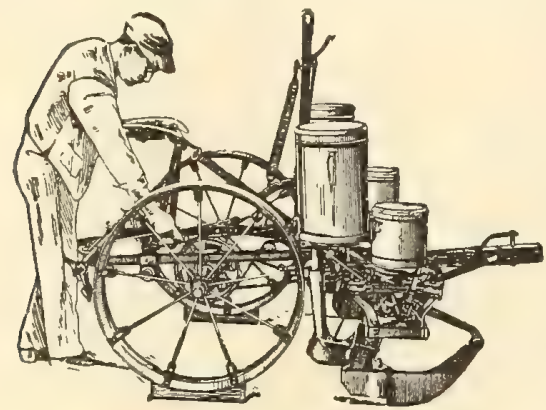

Our special new feature in this Planter is that we not only get an accurate number of kernels in each hill but we get the number of kernels in each hill which the quality of the soil is able to bring to perfect maturity. $\$ 91.25$

With Fertilizer Attachment. $\$ 122.50$

\section{Cole One-Row Corn Planter}

No. 11. Planter.............. $\$ 2200$

No. 12. Planter with Fertilizer Attach-

ment.

2650

\section{McCormick-Deering Engines}

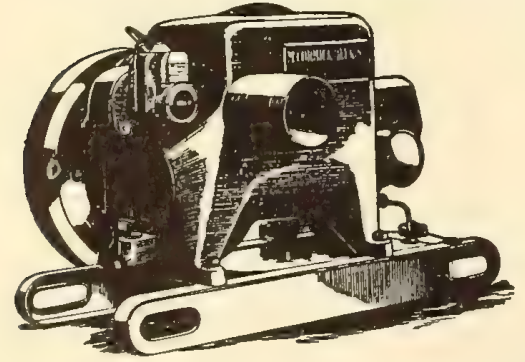

Very simple and perfect system of hopper cooling Frostproof Removable cylinder sleeve. Simple, effective kerosene mixer; unusually accessible and easy to operate. $11 / 2$ to $21 / 2$ H. P. Variable Speed.... \$72 50 3 to 5 H. P. Variable Speed.

10600

\section{AXLE GREASE}

1-Ib. cans Mica .

$\$ 020$

3-Ib. cans Mica.

25-lb. pails Mica .

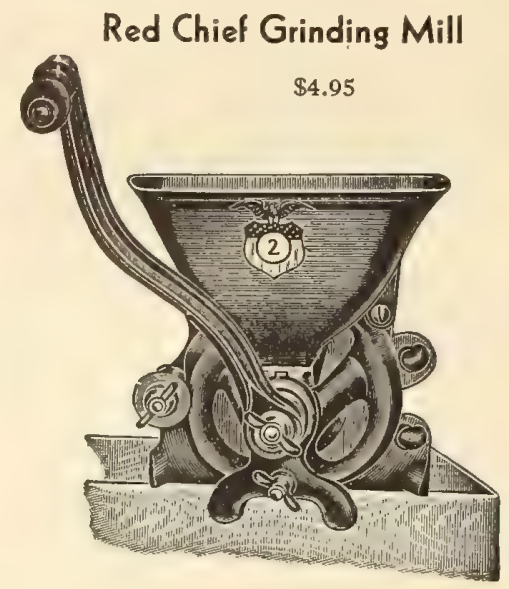

McCormick-Deering Hammer Mills

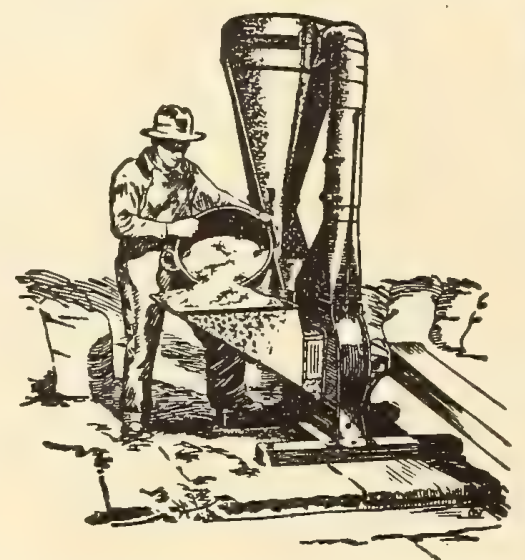

These fine, sturdy Mills will grind wheat, oats, barley, rye, shelled corn, ear-corn, Kafir corn, milo maize, hegari, feterita, cornstalks, hay, alfalfa, beans, peas, and grain sorghums, both headed and in the bundle, according to their rated capacities. No. 6. Hammer Mill. . . . . . . . . \$113 85 6-in. Type B Feed Grinder. ..... 3625 8-in. Type B Feed Grinder. . . . . . . 4975 10-in. Type D Feed Grinder. . . . . . 6325

\section{Red Chief Corn Sheller} $\$ 2.10$

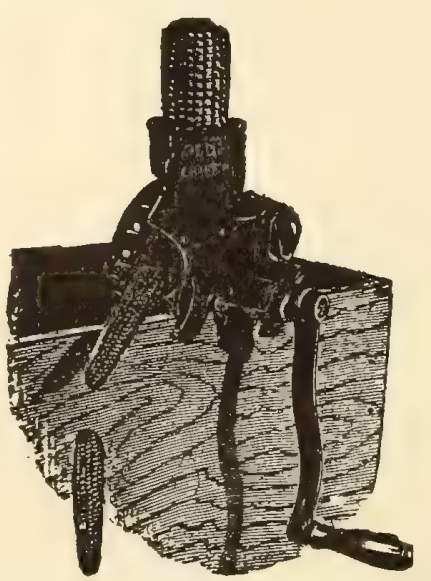

Hand and Power Corn Shellers

No. 3. Single Hole Sheller......... \$2000

No. 7. Double Hole Sheller (for hand or power).................... 4400

\section{Farm Belting}

$\begin{array}{lc}\text { Best quality } & \text { WRITE } \\ \text { 4-in., 4-ply } & \text { FOR } \\ \text { 5-in., 4-ply } & \text { PRICES } \\ \text { 6-in., 4-ply } & \end{array}$

Hay Cars and Track

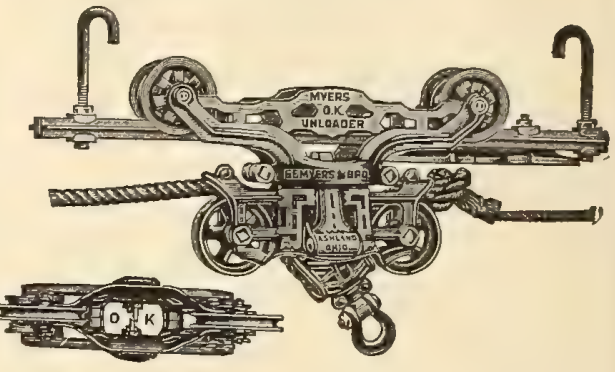

No. 201. 5-in. Pulley and Sheaves. .\$13 25

No. 208. 7-in. Pulley and Sheaves. . 1675

Double Harpoon Hay Fork. ....... 450

Double Steel Track with Clamps, per foot

Hangers, each

$.271 / 2$

Rafter Brackets, per $100 \ldots \ldots \ldots 600$

Floor Hooks

Knot Passing Pulleys . . . .

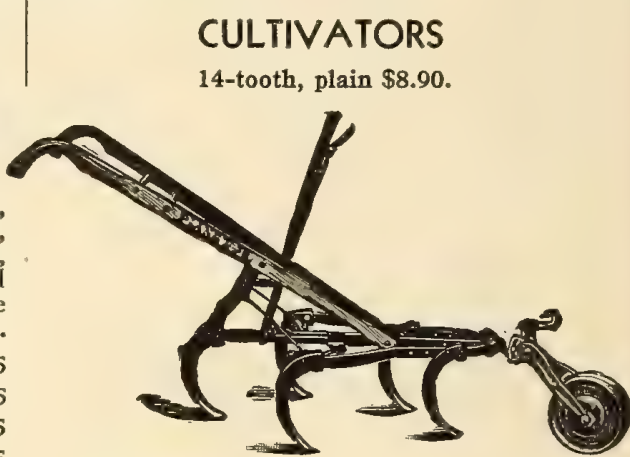

5-tooth, lever................\$8 75

5-tooth, plain................. 745

14-tooth, lever............... 965

\section{McCormick-Deering New No. 4}

Two-Horse Riding Cultivator

The most popular Riding Cultivator made. Hill-dodging is accomplished by means of two fork pedals placed just right for driver's feet. An easy pressure on either pedal pivots the wheel-axles, carrying the Cultivator to the right or left, as the case may be. At the same time the gangs shift sideways keeping the shovels constantly parallel. So easy to operate that a boy can do the work of a full-grown man. Cultivator, with 6 shovels. . . . . . $\$ 7150$ Cultivator, with 8 shovels....... 7450

\section{Oliver Plows}

AC. One-horse $\$ 1150$

No. 13. Two-horse, Light. ........... 1775

No. 19. Two-horse . . . . . . . . . . 1875

No. 20. Two-horse. . . . . . . . . . 2050 


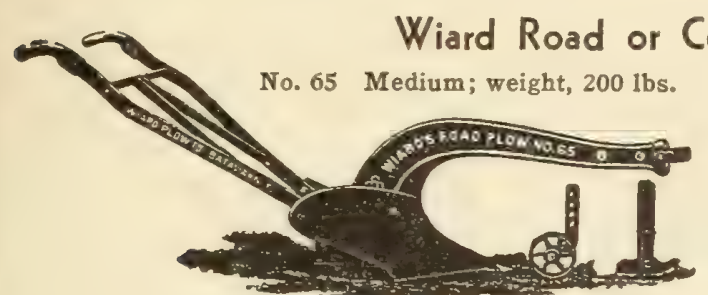

Plow, without Wheel or Shoe Forged Steel Point

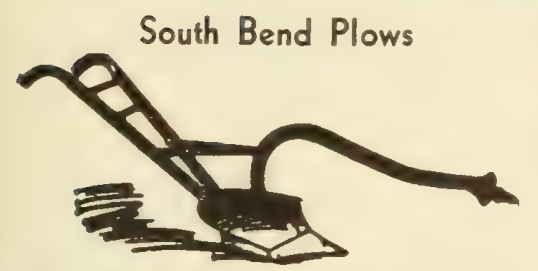

1-B. One-horse.

2-F. Two-horse, light.

21/2-F. Two-horse, light.

3-F. Two-horse, medium

$\$ 1375$

1625

1825

1925

\section{Syracuse Plows}

No. 2-78 RH. 10 to 13 in. width...\$20 35 No. $10-78$ RH. 14 to 16 in. width... 2560 No. 20-78 LH. 11 to 14 in. width... 2200 No. 30-78 LH. 14 to 16 in. width. . 2560

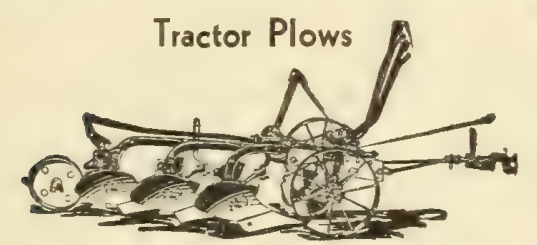

Little Genius. Heavily built for sturdy service, yet due to 3 -wheel construction is of very light draft. Two 14 -in. bottoms, $\$ 127.50$.

Little Wonder. A light, 2-wheel Plow, giving exceptional satisfaction to all users. Two 14 -in. bottoms, $\$ 108.50$

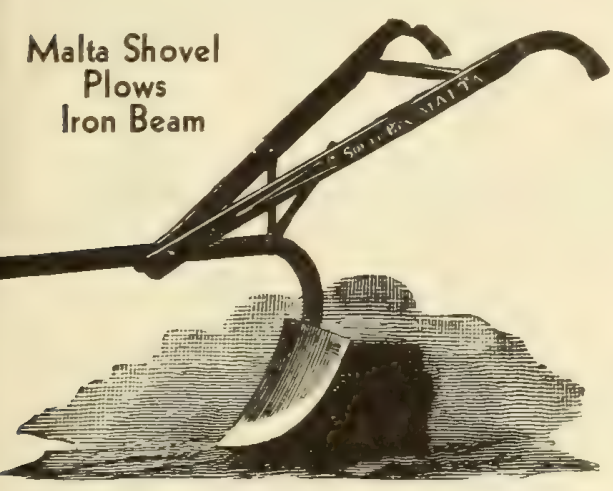

Double Shovel Plow

$\$ 560$

Single Shovel Plow.

495

Triple Shovel Plow.

\section{2-Ply Jute Twine}

Most used for tying vegetables and for general purposes. Lb., in ball or twist. .35c.

\section{Tarred Fodder Twine}

High-grade even Sisal twine, 50 strands to the twist. 21-oz. Lb. $21 \mathrm{c}$. Full bales of 25,50 and $100 \mathrm{lbs}$, at $20 \mathrm{c}$. per Ib.

\section{Contractors' Plows}

The cut illustrates the No. 65 Plow which is very substantial, and is heavy enough for ordinary road or contractors' work when used with 2 or 4 horses.

The cast-iron Point is made from the best quality of charcal iron, very strong and heavy. Plow, with Wheel or Shoe $\$ 36.25$. $\$ 3325$

...\$\$7.00 extra

\section{Binder Twine}

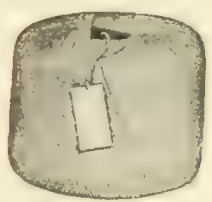

It is well understood that good Binder Twine is essential to successful binding. Uniform size and strength are the our Binder Twine. It will not kink and clog the knotter or pull thin and break. 500 feet to the pound. 5-Ib. ball, $65 \mathrm{c}$. Special prices on bale lots.

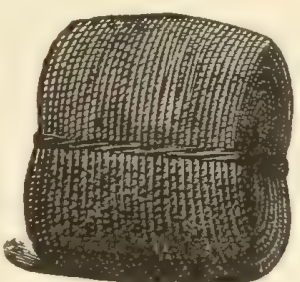

\section{Sisal Rope}

Always on hand, the best Sisal and Cotton Rope, in coils or by the piece, at prices consistent with the quality.

Prices on application.

Plow Lines

14 yds. $3 / 8$-in. Sisal rope. 55c.

Bolgiano's Improved Three-Row Marker
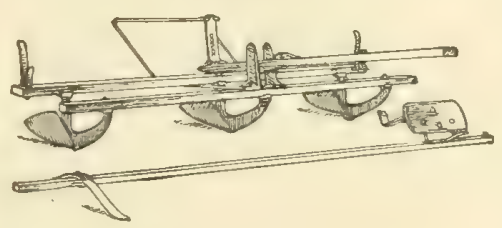

Has three chilled shoes, or runners, with steel wings, bolted on, and may be easily replaced when worn.

The frame is made of seasoned oak. The runners may be changed by loosening two bolts, to mark furrows 28 to 48 inches apart. With pole, without seat.....\$2200

The Original Improved Cyclone Seeder

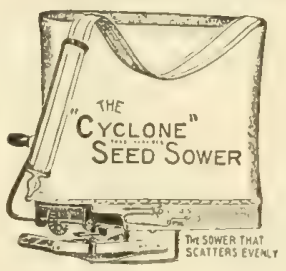

It differs materially and very advantageously from all other Sowers in having a slope feedlong hopper which terminates in a metal edge, on which edge oscillates a feed-plate which does not allow the seed to become clogged, but makes a positive force feed and insures a uniform flow and even distribution of seed. Anyone desiring a convenient, practical and all-round first-class grain and grass Seeder, a good, large sower that will meet the most exacting demands, we cannot recommend the Cuclone too highly. Parcel post weight, $6 \mathrm{lbs}$. $\$ 2.75$.

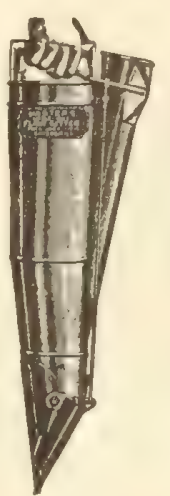

Master Plant Setter

Used to transplant cabbage, tomato, sweet potato, to-
bacco, cauliflower and similar bacco, caulnfower and similar plants perfectly and wrth minimum effort. The device sets, waters, and covers every without the necessity of stooping. $\$ 5.50$.

\section{Horn Seeder}

Makes even broadcasting a sure process in the hands of all users. \$1.00.

\section{Lanterns}

Supreme..... Red Globe

Little Wizard.

\section{De Laval Cream Separator}

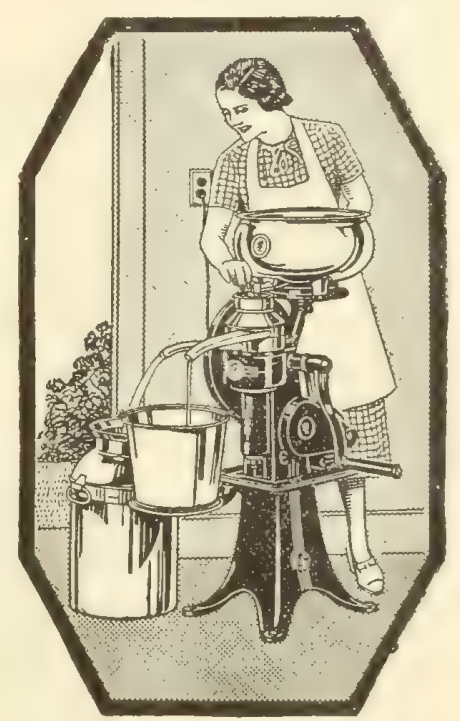

A remarkably easy-running Separator. It gets all the cream which may be regulated to test from 15 to 55 per cent butter-fat by an easily adjusted cream-screw.

\section{STANDARD SERIES}

Ball-Bearing

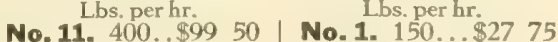

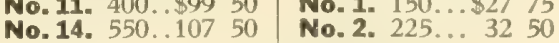

No. 18. $800 \ldots 12000$ No.3. $300 \ldots 4175$

Stand, extra 1150

Do Your Milking with a De Laval

De Laval Hand Separator Oil. $1 / 2$ gal. 70 c.; gal. \$1.10.

\section{Stanchions}

No. 27. Stalls with Stanchions, ... \$13 15 No. 1211. Stanchions only ...... 365 End Partitions................ 325 No. 77. Water-Bowls............. 335

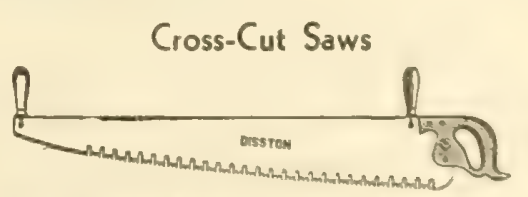

31. $-\mathrm{ft}$, 1-man. \$3 $85 \mid 51 \ldots-\mathrm{ft} .2-\operatorname{man} . \$ 3 \quad 27$ 4 -fi., l-man... $+35 \mid$ offt., 2-man... 3 th 5-ft., 2-man... 300

\section{ALL PRICES SUBJECT TO CHANGE WITHOdT NOTICE}




\section{Grindstones}

Steel Frame, No. 115

Sickle Grinder

$\$ 975$

\section{Cider Mills and} Berry Presses

AIl materials used in our Mills and Presses are carefully selected. Wood is extra heavy to assure greatest strength and rigidity. Screws are cold rolled steel with Acme thread.

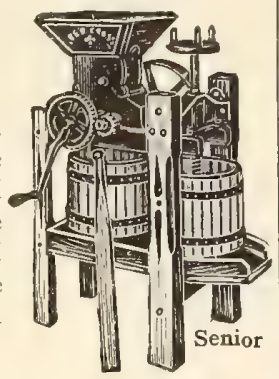

Single Cage Mill

Jr. Double Cage Mill

Medium Double Cage Mill

Sr. Double Cage Mill

No. 1-A. Berry Press.

No. 2-C. Berry Press.

Handy Crusher.

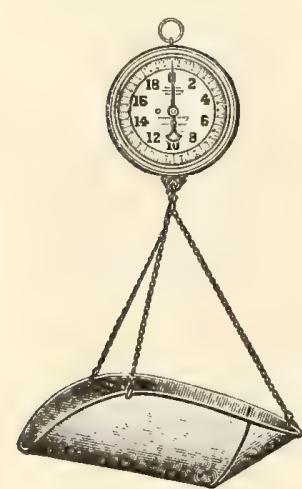

Certain-teed

Best Quality Roofing

One roll of Roofing is sufficient to cover 100 sq. $\mathrm{ft}$. of roof-space. Price given is per roll.

1-ply.

$\$ 175$

3-ply.

$\begin{array}{ll}2 & 10 \\ 2 & 60\end{array}$

Red and Green Slate

Top Roofing.

Corporal Roofing.

1-ply.

3-ply.

325

Scales

Huckster. 20-lb. with Scoop. $\$ 2.50$. Huckster. 20-Ib. with Scoop and glass-covered Dial. $\$ 3.25$

Scale. 40-lb., with Scoop. $\$ 2.95$,$$
\begin{array}{ll}
1 & 50 \\
1 & 75
\end{array}
$$$$
200
$$

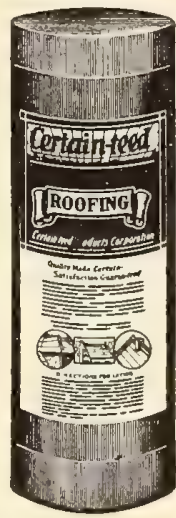

\section{Galvanized Buckets}

\begin{tabular}{|c|c|c|}
\hline \multicolumn{3}{|c|}{ Watering Cans } \\
\hline 4-qt. . . & $\begin{array}{l}. \$ 095 \\
.125\end{array}$ & $\begin{array}{l}12-q t . \ldots \ldots \ldots \$ 1 \\
16 \text {-qt. } \ldots \ldots \ldots 18\end{array}$ \\
\hline
\end{tabular}

\section{Wotherspoon Watering Pots}

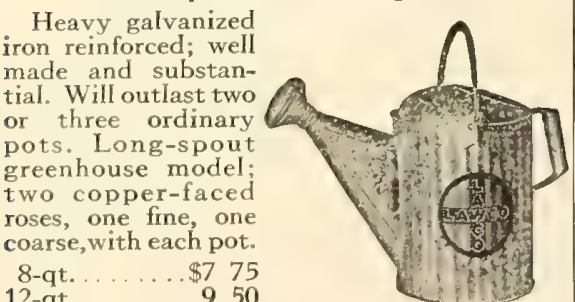

575

Harness

Halters, Leather. $11 / 4-$
in. Machine-made... $\$ 185$ Leather Cow Halter. . . 130 Bridles.............. 240 Trace Chains.... Set 120 Breast Chains. . . . . . to 140 Set. .95c. to 140
Butt Chains..... Set.. 110

\section{Tie-Out Chains}

$41 / 2-\mathrm{ft} . \ldots \ldots . \$ 035$

$20-\mathrm{ft} . \ldots . . .65$

30-ft....... 95

Tick-Lined Collars . $\$ 4.15$ up Red-Edge Collar-Pads. . 75c. Currycombs. 35 .

Horse-Brushes . $50 \mathrm{c}$, to $\$ 2.75$

Neat's-Foot Oil. Ot. $50 \mathrm{c}$.

$\begin{array}{ll}24 & 00 \\ 29 & 00\end{array}$

4100

875

640

Hame-Straps. 1-in., ma chine-made. Each 40c.; doz. $\$ 4.20$.

Hames, Virginia Cart. No. 61. Pair $\$ 1.90$.

\section{Wood Pumps}

For a plentiful supply of pure sweet water, Wood Pumps have never been excelled. AII our Pumps are made of Washington white spruce which is entirely tasteless and the best lumber now available for this purpose. All cylinders are porcelain-lined.

\begin{tabular}{|c|c|c|}
\hline & Size & \\
\hline $\begin{array}{l}\text { Depth } \\
12 \mathrm{ft}\end{array}$ & & \\
\hline & $\$ 2000$ & $\$ 2340$ \\
\hline $14 \mathrm{ft}$. & 2200 & 2545 \\
\hline $16 \mathrm{ft}$. & 2300 & 2650 \\
\hline $20 \mathrm{ft}$. & 2775 & 3100 \\
\hline $25 \mathrm{ft}$. & $\ldots$ & 3600 \\
\hline $30 \mathrm{ft}$. & & $40 \quad 00$ \\
\hline $35 \mathrm{ft}$. & & $45 \quad 50$ \\
\hline
\end{tabular}

\section{Water Barrel Truck}

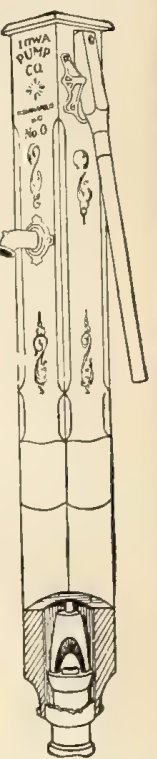

Our Barrel-Cart can be attached to any of our barrel spray pumps, and may be found useful in various ways, such as watering gardens, spraying trees, etc.

Steel Single Trees $\quad \$ 100$ Steel Plow Double Trees. Reinforced 160 Wooden Plow Set, Complete....... 400 U-Bar Steel Sct, Complete........ 350

Water Truck. 11/2-in. tire. . . . ... \$17 50 Water Truck. 3-in. tire. . . . . . . . . 19.50 BarreI, extra. ................. 600 Leaf-Rack....................... 1350

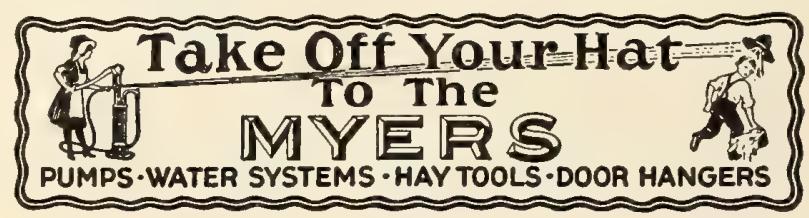

\section{Cog-Gear Pumps}

The patented rollingmotion cog-gear head operates $331 / 3$ per cent easier than the ordinary everyday Pump now in use and 50 to 100 per cent easier than antiquated types. As soon as you take hold of the handle you discover that the "rolling motion" cog-gear performs an important labor-saving service appreciated by every member of the family.

\section{For Shallow or Deep Wells}

R1052. Single-Acting Lift Pump. $\$ 15.25$.

With Foot-Valve. $\$ 16.40$.

R1072. Single - Acting

Force Pump. \$16.75.

With Foot-Valve. $\$ 17.90$.

R5. Double-Acting Force Pump, Windmill Top. $\$ 29.00$.

With Foot-VaIve. $\$ 30.25$.

For price complete with pipe and sucker rod on above three Pumps, add 25c. per footdepth of well less 4 feet.

No. 422. Myers Self-Lubricating Pump Jack. With $12 \times 2$-in. tight and loose pulleys, 6-in. stroke. $\$ 23.00$.

\section{Pitcher Pump}

No. 416. Myers LongStroke. 3-in. polished cylinder, with plain brass valve-seat, tapped for 11/4-in. pipe. Weight 21 lbs. $\$ 5.25$.

No. R416. Myers LongStroke, Cog-Gear. 3 -in. polished cylinder with plain brass valveseat, tapped for 11/421 Ibs. $\$ 5.50$.

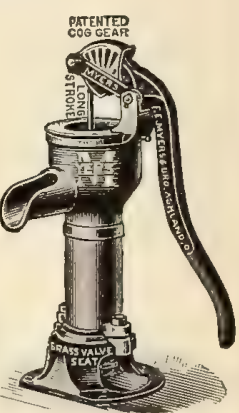

\section{Myers Self-Oiling Automatic Water Systems}

No. 1927AMT. Shallow Well ...... \$77 00 No. V2950AMT. Deep Well. 14175

Write for complete catalogue

\section{Well Buckets}

No. 121. Galvanized...........\$0 75 Victor...................... 140

\section{Crown.}

Well Chains

Lb. 12c.

ALL PRICES SUBJECT TO CHANGE WITHOUT NOTICE 


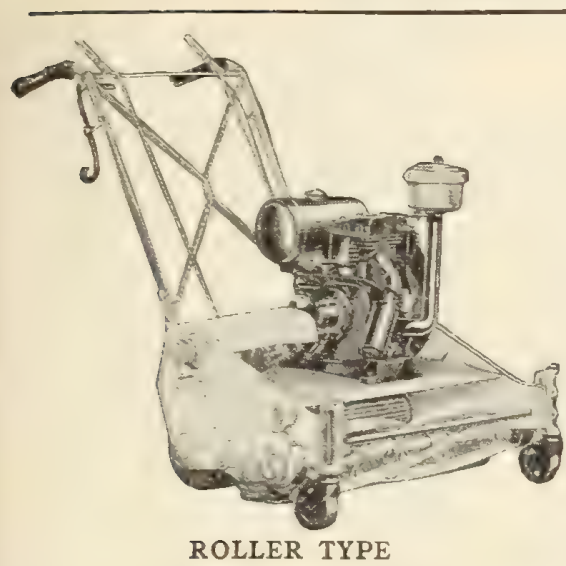

LAWN MOWERS

Lawn Mower factories are busy turning out War materials so we cannot supply Lawn Mowers, either Power or Hand, but we are doing our best to maintain a repair service so that owners of Cooper Power Mowers can keep their machines working until Victory makes new machines available.

\section{Grass Edger}

No. 2. Neat, good-looking lawns require that the edges be kept well trimmed. $\$ 1.60$.

Long Handle Edger. $75 \mathrm{c}$.

\section{Water Ballast Roller}

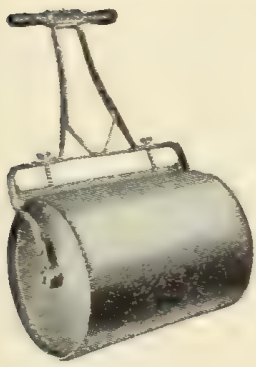

To increase the weight, add water. To decrease the weight, draw out water.

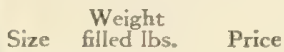
$14 \times 24175 \ldots \$ 1285$ $18 \times 24265 \ldots 1500$ $24 \times 24 \quad 420 \ldots 1825$ $24 \times 32566 \ldots 2150$

\section{Land Roller}

The Buch is the most popular Land Roller on the market. Heavy, stiff angles are used on the sides and ends to which the steel hangers are securely bolted, and the frame is so arranged that it will carry sufficient weight to suit the requirements. $\$ 50.00$.

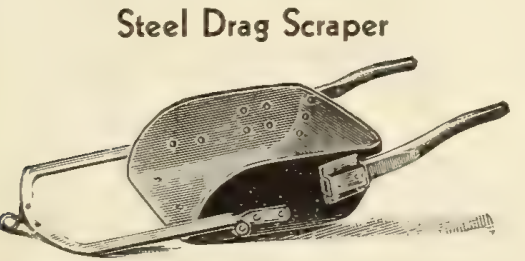

No. 1. Capacity about $7 \mathrm{cu}$. $\mathrm{ft}$. of earth, 98 lbs...............\$12 00

No. 2, Capacity about 5 cu. ft. of 1135 No. 3. Capacity about 4 cu. ft. of 1135 earth, 75 Ibs................ 1025

\section{Brooms}

Bass. 16-in.; 6-row. ...........\$1 90

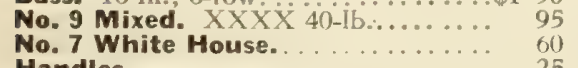

WASHINGTON, D. C.
Richmond Sod Cutter

This highly efficient machine cuts a strip of sod 14 inches wide of uniform thickness power or tractor use only. $\$ 39.50$.

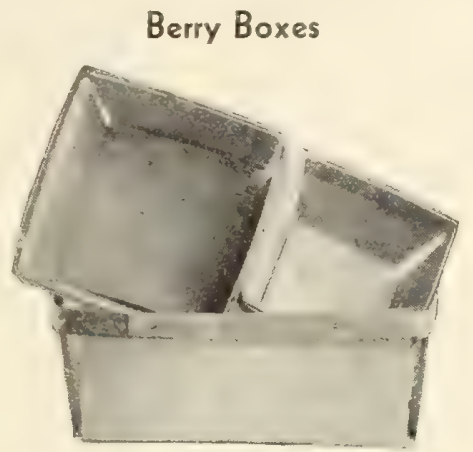

Prices subject to market changes in berry season.

Write for special quantity prices.

$\begin{array}{cccc}\quad & \text { Doz } & 100 & 1000\end{array}$

Square. $1 / 2$-pt......\$0 12 \$0 90

Long, 1 -pt.......... $12 \quad 90 \quad$ Write

Square. 1-qt........ $12 \quad 75$ for

Long. 1-qt........ $20 \quad 150$ Prices

Long. 2-qt....... $24 \quad \begin{array}{ll}1 & 75 \\ & \end{array}$

Peach Baskets. $1 / 2$-bus.

Round Baskets. $1 / 2$-bus.
Round Basket Tops. $1 / 2$-bus. Write

Round Basket Tops. 1/2-bus. Write
Round Baskets, 1-bus.
Round Basket Tops. 1-bus.

Corrugated Caps. 1-bus.

Paper Liners. 1-bus.

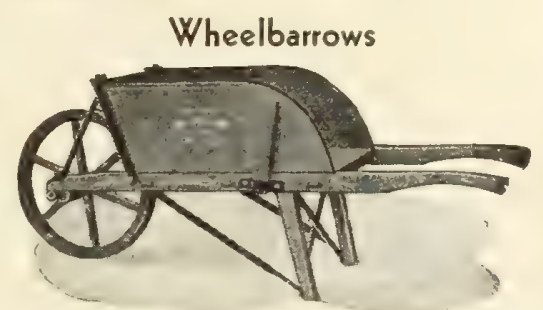

No. 1. Buch's. Large Size...... \$9 $\$ 00$

No. 3. Medium size

765

Duchess Barrow. Steel tray and wheel 625

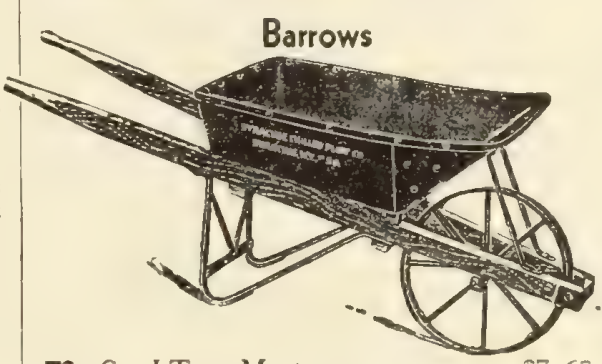

F3. Steel Tray Mortar...... \$7 65

Golf. 4 -in. wheel.............. 1225

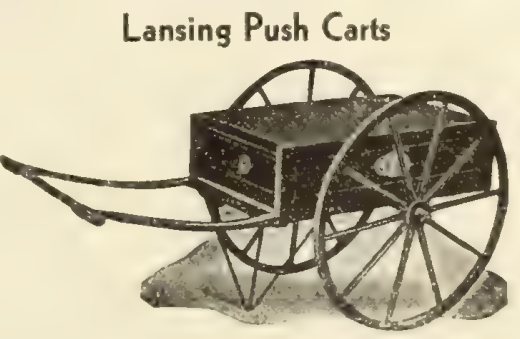

Size of Box

No. $0.48 \times 28 \times 10$

No. $2.32 \times 20 \times 9$.

$\$ 2290$

$\begin{array}{ll}20 & 75 \\ 19 & 25\end{array}$
Greenhouse and Estate Power Sprayer

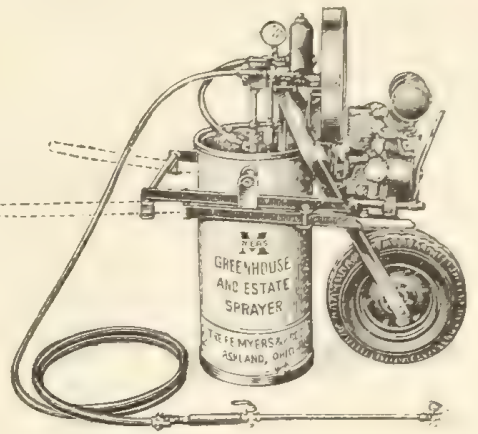

A new, compact, portable, motor or engine powered, completely equipped Sprayer with folding handles for inside spraying where aisles are narrow-for outside spraying of small trees, shrubbery, vegetables, vines and flowers, etc. Motor-driven, $\$ 110.00$. Enginedriven, $\$ 120.00$.

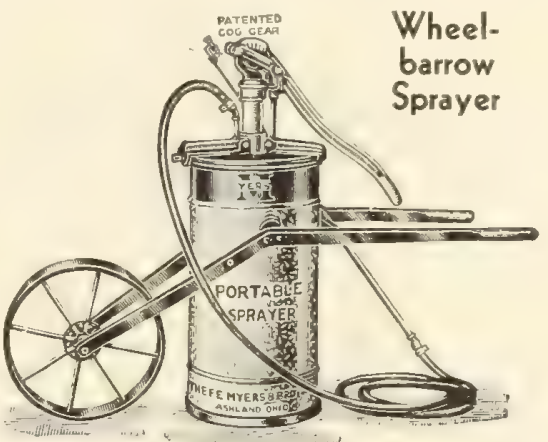

A most popular outfrt, being strongly mounted on a steel truck. Can be wheeled anywhere with ease. Capacity, 12 gals. R 336 B. Equipped with heavy-duty pump. $\$ 28.00$.

R 338 B. Equipped with light pump. $\$ 21.00$.

\section{Barrel Sprayers}

These Sprayers ating cog-gear head, mechanical agitator, solid brass ram plunger, ground bevel brass valve and chamber. This construction enables the operator to carry up pressure, sufficient to supply
two heads of hose satisfactorily. Adjustable mal-

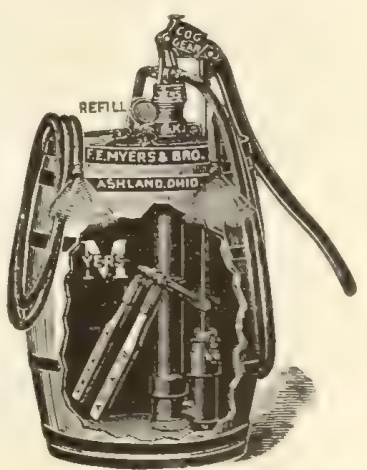

permits Pump to be used in different size permits

R. 308B. Heavy Duty.

$\$ 3350$

R 318B. Standard.

If wanted without barrel, take from

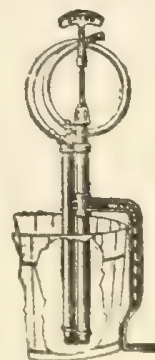

\section{Spray Pumps}

Brass Bucket Pump Attachment, etc., with 3-ft. of "s-in. discharize home and Seneca spray nozzle.

No. $3271 / 2$

No. 323

450

Cog-Gear Lever Bucket Sprayer. No. R324. \$7.25. 
Myers Compressed Air Sprayer

The tank is made of heavy galvanized iron or brass. Side walls are double seamed, riveted and soldered. The top and bottom are extraheavy material with flanged edge over which the side walls are turned and thoroughly soldered.

21/2-gal. galvan-

ized tank .....\$6 50 4-gal. galvan-

$$
\text { ized } \operatorname{tank} \ldots \ldots 725
$$

4-gal. brass tank 1150
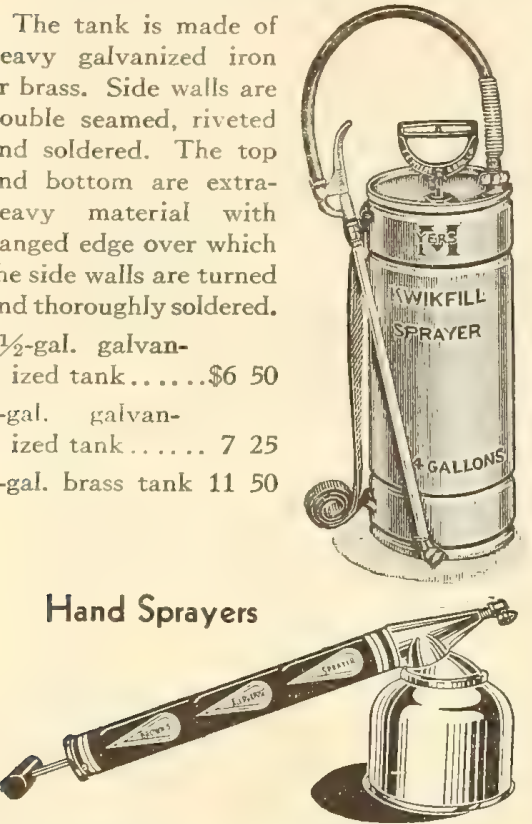

For spraying all insecticides for flowers, garden, shrubbery, etc. Excellent for spraying disinfectants, fly spray and cattle spray.

\section{Continuous Sprayers}

1-qt., all tin..................\$0 95

1-qt., glass....

1-qt., brass

195

\section{The Arnold Garden Hose Sprayer}

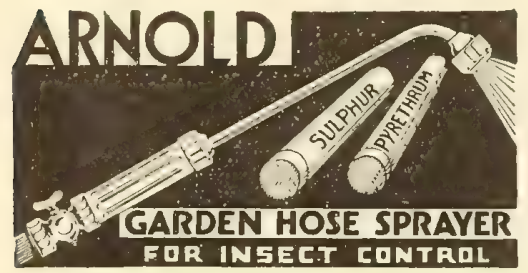

A special mixing and spraying nozzle which attaches to your garden hose in place of the regular nozzle. It was designed to take the hard labor out of garden spraying. Cartridges supplied for practically all spraying purposes.

Arnold Complete Sprayer........\$4 00 Arnold Combination Set.

575

Set consists of a Complete Sprayer and 6 Cartridges; 2 P-R, 2 Colloidal Sulphur, 1 Nicotine, 1 Fertilizer.

\section{Harco Sprayer}

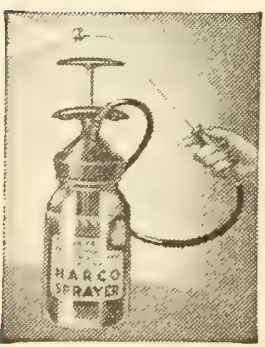

Here's the effricient good-looking, easyto-use Sprayer you want at the down-toearth price you want to pay! Sprays up, down, sideways without adjustment. No Ieaks or drips to wet hands or stain clothing. \$2.35.

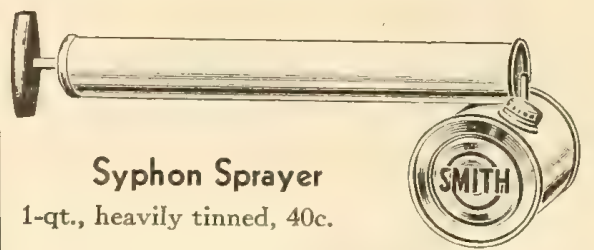

\section{Savage Junior Duster}

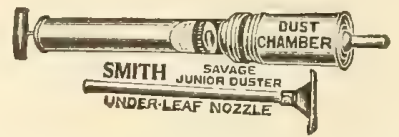

Dusts without waste, and easily operated. Long air-chamber develops strong blast. Large dust-chamber. Thorough atomization of poison. Throws long, broad dust-blast straight ahead or underside of leaves on low-growing vines or at any angle. \$1.10. Dustmaster with glass container, $\$ 1.25$.

\section{Sprabulb}

For years florists, seedsmen and housewives throughout the U. S. A. have found the handy Sprabulb an excellent water and powder sprayer for plants. $8-o z$. 79c.; 12-oz. \$1.30.

\section{Soil Soakers}

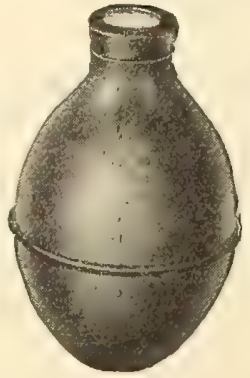

No Run-off-No waste-No soil-washing \begin{tabular}{l|l|l} 
No. 0. $12 \mathrm{ft} . . . \$ 1$ & 40 & No. 2. $30 \mathrm{ft} . . \$ 290$
\end{tabular} No. 1. $18 \mathrm{ft} . .190$ No. $190 \mathrm{ft} . .475$

\section{Chicago Portable Spray Head}

This sprinkler can be connected between short lengths of hose to cover considerable distance. Each sprinkler is adjustable to assure uniform sprays when used in a series. Each $85 c_{*}$; set of $3, \$ 2.40$.

\section{Zenith.}

$\$ 175$

Dollar Revolving

100

Hose Nozzles, all brass, each $30 \mathrm{c}$ and $60 \mathrm{c}$

\section{Improved Ring Sprinkler}

The Heaviest All-Brass Ring Sprinkler on the Market.

The Allen Ring Sprinkler throws a finely divided, well-distributed, coarse spray, covers a large circle, and can be conveniently moved without shutting off the water. \$1.10.

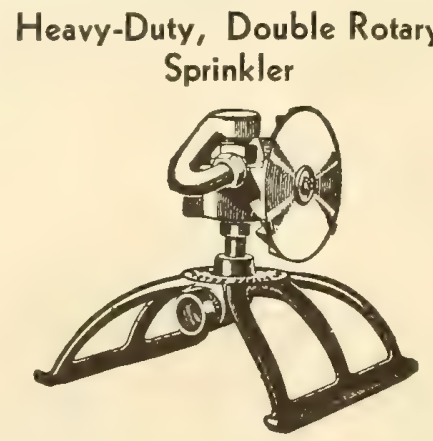

Many of the country's finest golf clubs, park commissioners, nurserymen, and ceme tery associations now use and endorse this heavy-duty model. $\$ 12.50$.

Junior Rotary Sprinkler. $\$ 7.50$.
Flex-Nek

Nozzle Holder

Holds nozzle frrmly in any position-changed instantly and stays that way. $89 \mathrm{c}$.

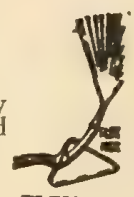

\section{Water Wand} TLX- NES

Whater yrand ime savik ron gatpiares

The regular task of watering the garden becomes a real joy-you don't even soil your hands-no need to change to garden clothes. It weighs only one pound. The long, light-weight handle enables you to direct a gentle flow of water to the back of large flower-beds without stepping into the soft soil or tramp-
This is just the tool

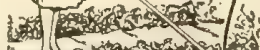

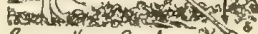
Feres dome Gardener so ling the delicate plants. This is just
you have been looking for. $\$ 2.50$.

\section{"Little Wonder" Hedge Trimmer}

Speeds up work where electricity is not to be had.

One-Man. 30-in.......

$\$ 3375$

Two-Man. 40 -in............... 3675

\section{Dumore Electric Hedge Trimmer}

$\$ 29.50$

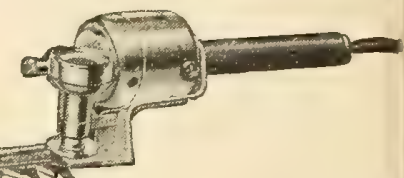

Price within the reach of those who are interested in beautifying their homes and pays back its cost each season through saving tedious hand Iabor-making your hedges a source of pride and definitely adding to the value of your property.

\section{SPREADERS}

For Fertilizer, Lime or Seed

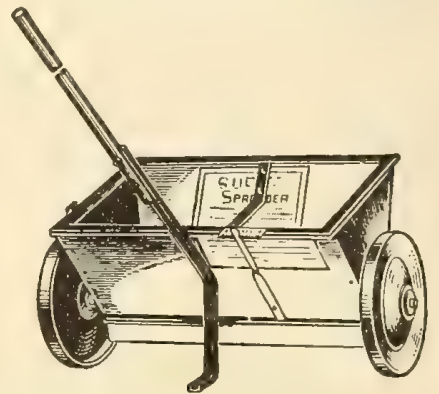

The 20-inch and 30-inch Spreaders are as rugged and dependable as of old. Hoppers made of heavy gauge material with patented automatic shut-off. The agitator distributes fertilizer or seed in correct amounts; accurately regulated by the feeder slides.

The New 16-inch Spreader, correctly named "America's Greatest Value," fully equipped, embodies all the features of the Iarger Spreaders. It is the right size for small lawns and in the price-range of all

Each machine pays its own way because it distributes fertilizer and other materials evenly and in the proper amount 16-in. $\$ 3.75$; 20 -in., $\$ 7.50$; 30-in., $\$ 14.95$.

Heavy-Duty. 24 -in., $\$ 17.50 ; 36$-in., $\$ 24.00$

ALL PRICES SUBJECT TO CHANGE WITHOUT NOTICE 
Shovels, Long-Handled

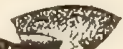

Special. Round point. Ames. Round point. Ames. Square point.

\section{Spades}

Special. " "D" handle

Ames. "D" handle.

Boys' or Transplanting

Nursery .

Gold Target No. 2

Spades, Long-Handled

Ames.

Spading Forks

D' handle; light... .

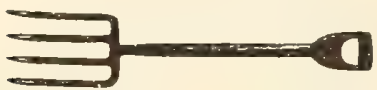

"D" handle; heavy.

Pitchforks

Acme. 4-tine.

Regular. 4-tine.

Special. 4-tine

Long-handled. 3-tine

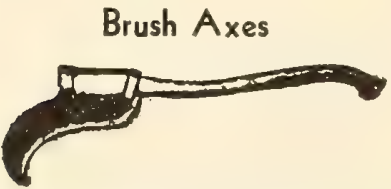

Two in one Ax and Hook. Brush Ax.

Short Hand Brush Ax.

\section{Axes}

$31 / 2$ to 4 -lb., without handles $31 / 2$ to 4 -Ib., with handles.

Handles

Ax.

Pick.
Rake

Garden Hoe

41/2-ft. Shovel

6-ft. Fork, Strapped.

"D" Spade.

"D" Spading Fork. Strapped

"D" Manure Fork

"D" Shovel.
$\$ 250$

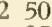

25

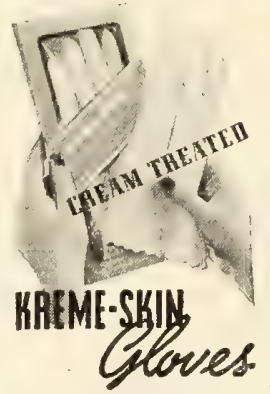

Asparagus Knives or Weeders

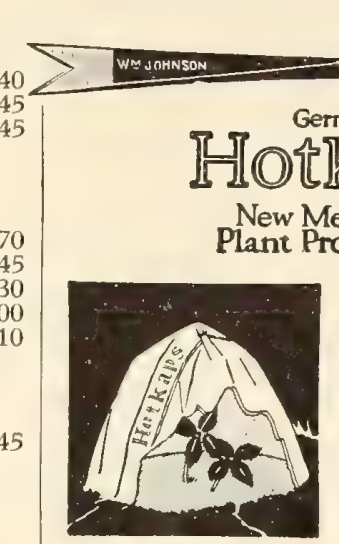

New Method of
Plant Protection 25 Hotkaps 50c. Postage or Express extra. Write for quantity prices and pamphlet.

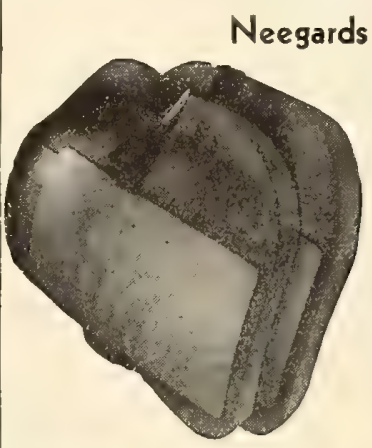

Cotton Gloves. Leather

palm. Heavy cotton....\$0 45

Medium Weight Cotton. 25

Scythes

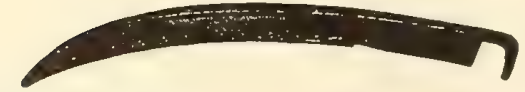

American Grass.

Diamond Bush. Assorted

Snaths

Patent.

Rings.

Scythe Stones

Darby Creek.

cythe Stones

\section{Time-Saver Adjustable} Plant Supports

$\$ 175$

$\$ 180$

Made of heavy wire and cord. Adjustable for both height and diameter.

No. 2. $3 \mathrm{ft}$. high. . \$0 $15 \$ 120$ No. 3A. 4 ft. high. $20 \quad 220$ No. 4. $5 \mathrm{ft}$. high... 25275 Peony Supports. Each 35c.; doz. $\$ 3.30$.

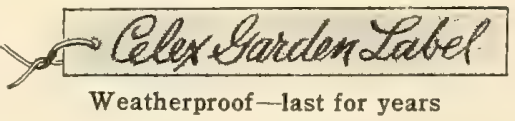

$\$ 020$ Doz. 25c.; 25, 45c $45 c$
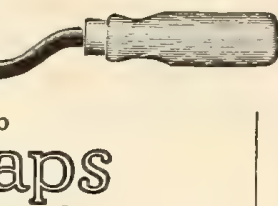
Steel Tamper $\$ 1.95$

The Modern Knee-Protector

Neegards are an absolute necessity for men and women who do any work that requires kneeling on the ground. They are completely adiustable and form-frtting to fit any size
knees. $\$ 1.10$.

\section{Kreme-Skin}

\section{Gloves}

Made from soft and select hides. Semi-styled both work and playgardening, bousebold, driving, etc. Give full protection with utmost protection with utmost comfort and finger freedom. Also softens the hands. Washable. Ladies' sizes only (Small, Medium, Large) Pair

Bloomlife

Cut-flower food especially developed to give extra life color, and fragrance to all hard-stem blooms. $10 \mathrm{c}$.

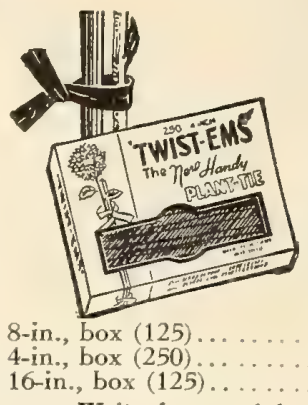

Twist-Ems

The New Hardy Plant-Tie

Darkgreen strong tapes with wire reinforcing that make perfect plant-ties. For plants, vines and shrubs and arranging flowers.

.$\$ 025$ 25
50

Write for special quantity prices

\section{Perfecto Window-Boxes}

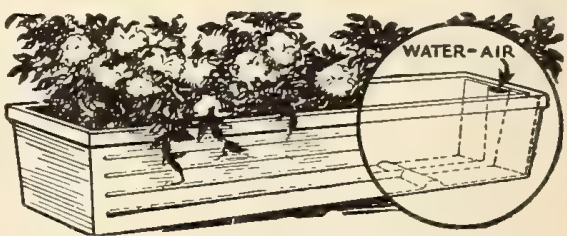

Made of copper-bearing steel, heavily lead-coated. Guaranteed 5 years. Far superior to galvanized boxes. They are scientifically ventilated so that the roots of the flowers will not rot. Made in frve sizes.

20 in. long.

26 in. long.

32 in. long.

$38 \mathrm{in}$. long
$44 \mathrm{in}$. long.

$\$ 135$

65

190

$\begin{array}{ll}2 & 75 \\ 3 & 25\end{array}$

Labels

Plant.

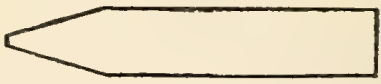

31 $\frac{2}{2}$-in. Painted; Doz. $20 \quad 100 \quad 1000$ copper-wired... $\$ 0 \quad 10 \$ 0 \quad 40 \quad \$ 3 \quad 20$ Pot. 4-in. Painted. $\quad 10 \quad 35 \quad 2 \quad 15$ Pot. 6-in. Painted $\quad 10 \quad 40 \quad 260$

Garden- 8-in.

Plain........\$0 $15 \quad 80 \quad 650$

Copper. $3 / 4 \times 33 / 4$-in.

Copper-wired,.. $25 \quad 200$

Stylus for above, each $10 \mathrm{c}$.

\section{Metal Plant Props}

Press the Prop

firmly in the ground alongide of the plant and push the plant gently

through the opening at the top. The four sizes will take care of practically all garden plants. Overall Doz. 16-in... . .\$0 45 30 -in.... 85 66 -in..... 150 Write for prices on larger

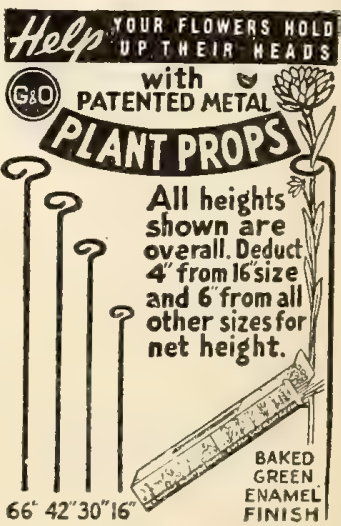




\section{Dirt-Bands}

These form square, bottomless pots that can be transplanted without removing plant from pot or disturbing roots. $3 \times 3$ in.,

\section{Wayward Vine Guide and Support}

For training and supporting ivy and other vines, etc., on brick, stucco, stone and cement walls without defacing. No Nails-No Holes. Box of $25, \$ 1.00$.

\section{Raffia}

For tying asparagus; also used extensively for tying plants to stakes. Prices given on request

\section{Hog and Cattle Steel Wire Fencing}

$\begin{array}{llr}\text { No. 726. Hog Fence } & \text { Height } & \text { No. bar } \\ \text { No. 832. Hog Fence } & 32 \mathrm{in.} & 7 . \\ \text { No. } 845 \text { Cattle Fence } & 45 \mathrm{in.} & 8 \ldots \\ \text { No. } 1047 \text { Cattle Fence } & 47 \mathrm{in.} & 10\end{array}$
$1000, \$ 4.15 ; 500, \$ 2.15 ; 100,75 \mathrm{c}$; d doz. $15 \mathrm{c}$.

\section{Diamond Mesh Poultry Fence}

Height
12 in..
18 in..
24 in..
30 in..
36 in..
48 in..
60 in..
72 in..

\begin{tabular}{ll}
\multicolumn{2}{c}{2 -in. mesh } \\
Per foot & Per roll \\
$\$ 02$ & $\$ 1.35$ \\
$021 / 2$ & 180 \\
03 & 230 \\
$031 / 2$ & 280 \\
04 & 325 \\
$041 / 2$ & 425 \\
05 & 520 \\
06 & 615
\end{tabular}

\begin{tabular}{|c|c|}
\hline Per foot & Per roll \\
\hline$\$ 003$ & \\
\hline 04 & 36 \\
\hline 05 & \\
\hline 06 & \\
\hline 07 & 1 \\
\hline 08 & 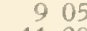 \\
\hline 10 & 11 \\
\hline 12 & 17 \\
\hline
\end{tabular}

\section{Wickets}

1/4-in., 22 in. high, 12 in. wide, painted green, $12, \$ 1.00$; postage extra. Shipping weight, 9 lbs. per doz.

\section{Fancy Lawn Fence}

The fabric illustrated herewith is superior to any I awn Fence on the market. The upright wires are corrugated their entire length instead of at intervals. Close enough at bottom to turn the smallest nimals.

The uprights are of No. 9i/2 heavy galvanized wire, spaced 27 inches apart, with an extra upright of No. $91 / 2$ interwoven at the bottom, giving a spacing of $13 / 8$ inches. The cables are of heavily galvanized wire spaced 6 inches apart, except the two top cables, which are spaced $1 / 2$ inch apart. Style 100 Single Style 600 Double Height

36 in.

42 in.

$\begin{array}{cc}\text { Ft. } & \text { Ft. } \\ \$ 012 & \$ 016\end{array}$

48 in. 14

Flower Border. 16-in., ft. 9c.; 22-in., ft. 10c.

Trellis. $18-\mathrm{in}, \mathrm{ft} .10 \mathrm{c}$

Special prices on quantity.

\section{Lawn Gates}

$3 \mathrm{ft}$. by $36 \mathrm{in.}$

$3 \mathrm{ft}$. by 42 in..

$3 \mathrm{ft}$. by $48 \mathrm{in}$.

Drive Gate.

Drive Gate. $12 \mathrm{ft}$ by $58 \mathrm{in}$.

Double Drive Gate. $10 \mathrm{ft}$. by $42 \mathrm{in}$.

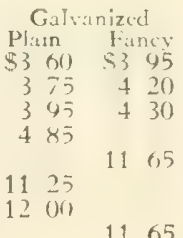

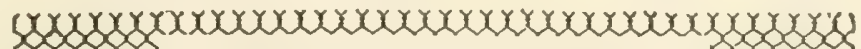
CHAIN LINK FABRIC

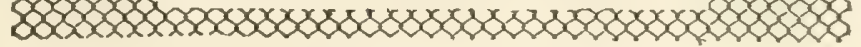

Makes a strong non-climbable, attractive fence

2-inch mesh, No. 11 Guage

\section{American Steel Poultry Fence}

No. 2048. $48 \mathrm{in}$

$10-$ rod roll

No. 2360. 60 in

No. 2672. $72 \mathrm{in.}$

\section{American Tubular Galvanized Steel Posts}

The strongest and most sturdy line-post made. $5 \mathrm{ft}$...

$\$ 063 \mid 7 \mathrm{ft}$.

$\$ 085$ $61, \ldots$

$80 \mathrm{ft} / \mathrm{ft}$

\section{Drive Caps.}

Ball Tops.

Corner Posts, Double Braced

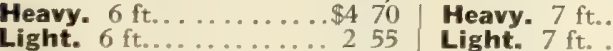$$
5
$$$$
\text { End Posts, Single Braced }
$$$$
\text { Self-Fastening } \boldsymbol{U} \text { Posts }
$$$$
\begin{array}{r|r|r}
\$ 0 & 37 & 7 \mathrm{ft} . \\
43 & 8 \mathrm{ft} .
\end{array}
$$

Special prices on quantity.

Post-Hole Diggers

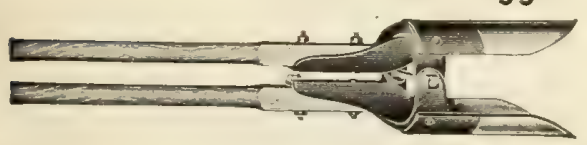

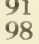

60

23

$\$ 535$

300

$\$ 385$

210

$\$ 048$

54
\$0 23

42-in. Galvanized before weaving.

Special prices on quantity.

\section{Barb and Strand Wire}

Barb Wire. 5 in. between barbs. 80 rods 2-Strand Twist Wire. 80 rods.

\section{Staples}

$3 / 4$ or $7 / 8$-in., for poultry wire, lb. 12c; $\mathrm{keg} . \$ 7.25 ; 11 / 4$-in. for stock fence, lb. $10 \mathrm{c}$.; $\mathrm{keg} \$ 5.75$.

\section{Nails}

3 to 60-penny, at market price. Write for quotations.

\section{Prime Electric Fence}

One wire, connected to Prime Controller holds horses, cattle and hogs. Easily, quickly set up and moved for temporary or permanent pasture. Prime, the best, most dependable controller; proved service on tens of thousands of farms. Built according to the Electric Fence Reexaminaion Service standards established by the Underwriters' Laboratories.

No. 480. 110-volt.

No. 420. 110-volt

Battery Models

$\$ 4250$

3250

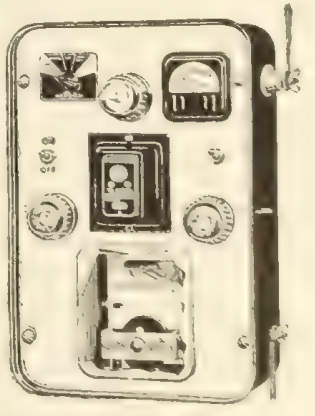




\section{INSECTICIDES}

ACME 75 ROTENONE SULPHUR DUST. An effective non-poisonous insecticide.

ACME ANT-KILL. Rid your home and premises of the embarrassing and health-injuring ant nuisance. Kill the ants in the nest. Ant-Kill

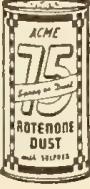
nection with safe patwhich sives protection to birds, chickens, pets and children, yet read ily accessible to ants back to the nest. Attractive to Argentine Junior Set.

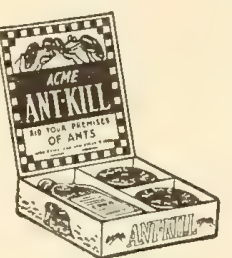
Cottage Set.

Syrup. 2-0
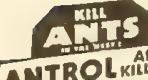

ANTROL KILERS

Fi 8 , Cry

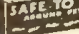
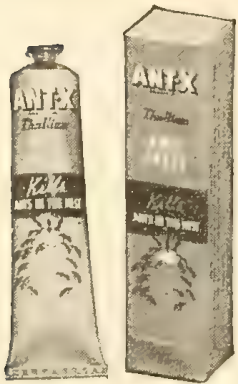

Antrol. Easy to use, economical, safe around children and pets. Consists of small glass containers from which worker ants carry spetheir nests for food. The whole ant family is quickly killed at the source. Controls both sweet- and grease-eating ants. Guaranteed Iroved homes. Antrol Ready - filled Set, containing 4 flled feeders, 40c. Antrol Regular Set, 4 containers and 4 -oz. bottle syrup 60 introl Syrup for refilling, 4-oz. bot-
tle 20c.; 1-pt. bottle $50 \mathrm{c}$.

Antrol Ant Traps. 10c.

Ant-"X" Jelly. Prepared ant-bait in handy convenient tubes. Brings swift death to ant legions-used indoors or out a sure kill for nest or hill. 1-oz. tubes $\$ 1.00$.

ACME APHIS SPRAY. An improved nicotine spray combining a soft frsh-oil soap with BlackLeaf 40. Suitable for the control of all kinds of aphis (plant-lice) and $35 \mathrm{c}$.; 12 ozs. $\$ 1.00 ; 21 / 2$ lbs. $\$ 2.35$.
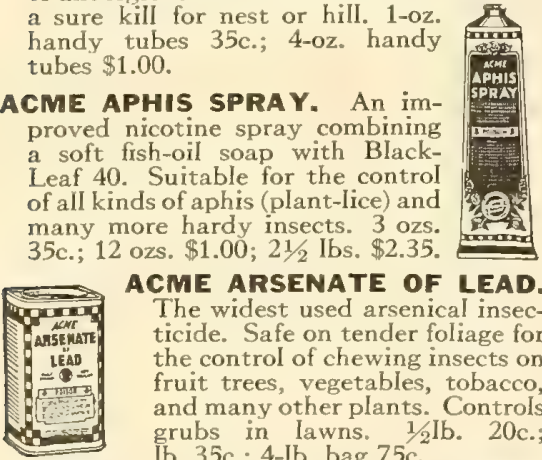

ACME ARSENATE OF LEAD.

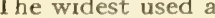
ticide. Safe on tender foliage for the control of chewing insects on fruit trees, vegetables, tobacco, and many other plants. Controls grubs in lawns. $1 / 2 \mathrm{lb}$. 20c.;

\section{ACME BAIT-M WITH METAL-} DEH YDE. An attractive insect Daitection. Contains metaldehyde, the marvelous new discovery for control of chails and slugs. Also contains

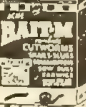
worms, earwigs, sowbugs, grasshoppers, ground. 11/2 lbs. 35c.; 4 Ibs. 85c.; 15 Ibs. $\$ 3.00$

Black Arrow Dust. A Pyrethrum dust. Lb. 50 c.; 10 lbs. $\$ 3.80$.

FOR LARGER

QUANTITIES ASK FOR

QUOTATION

\section{ACME BORDEAUX MIXTURE}

Prevents large losses caused by

blight, rot, mildew, scab, anthrac-

nose, etc. Stimulates plant-

growth, increasing the harvest.

Almost every kind of vegetable,

fruit, and shrub can be improved 4 lbs. $75 \mathrm{c}$.

"Black-Leaf" 40

Nicotine Sulphate -40 per cent Nicotine

Destroys aphis (plant-lice), thrips, leafhoppers on all tree, the vine fruits, vegetables, freld crops, flowers and shrubs, also apple red bug, pear psylla and similar soft-bodied sucking insects-aIl without injury to makes 80 to 250 gals. Oz. $35 \mathrm{c}$.; 5 ozs. \$1.05; Ib. \$2.50; 2 Ibs. $\$ 3.70$;

5 lbs. $\$ 6.90 ; 10$ Ibs. $\$ 11.65$

Calcium Arsenate. Especially effective against bean beetle when dusted with lime, using a 1 to 7 formula. Lb. 25c.; 4 lbs. 50c.; 24 lbs. $\$ 2.80$.

Carbon Disulphide. A liquid for killing weevil and grain moth. One pound treats Cannot be mailed.

Ceresan. Treats wheat, oats and rye for

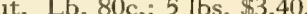

Coppercarb. A dry-dust treatment for seed wheat to kill smut spores. $5 \mathrm{lbs} .95 \mathrm{c}$.

Copper Sulphate (Blue Stone). Lb. 20c.; 5 lbs. 60 c.; 25 lbs. $\$ 2.50$

Yellow Cuprocide. A dry powder which mixes easily with water Spray Yellow Cuprocide on seed-bed soil and seedlings to protect the young plants from dampingoff. 3-lb. pkg. $\$ 1.50$.

CAvoCAS A modern fumigant for AS greenhouse or orchard use rodents, vermin, etc.

Cyanogas $G$ for greenhouse, mushroom and oil fumigation.

Cyanogas A to kill ants, rats, moles, woodhucks, fleas, moths, bats, etc.

$25-\mathrm{Ib}$. tins $\$ 10.00 ; 5-\mathrm{lb}$. tins $\$ 3.00$; 1 -Ib. tin $75 \mathrm{c}$; $1 / 2 \mathrm{lb} .45 \mathrm{c}$. Special Duster Can, 30c. Dog-Check. "The Modern Repellent." The only effectrve, proved curb to canine habits, needed by all whose neighbors dogs "visit" and wither flowers, lawns, hedges, shrubs and saplings. 3-oz. bottle, with sprayer, 60c.; 8-oz. bottle, with sprayer, $\$ 1.00$

ACME DAWG-GONE. Protect that evergreen - keep dogs away. Remove cap Dawg-Gone (opening down) in the lower

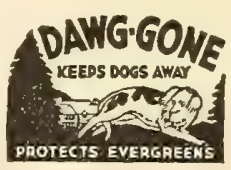

branches of trees at the points of approach. The odor slowly emanating from the open tube will keep dogs at a distance. Mailable. Tube $25 \mathrm{c}$.

Dogzoff. A spray that discourages dogs from the habits that are so destructive to evergreens. One spraving lasts several weeks. Season's supply 60 c.

Dritomic Sulphur. Recommended for the control of scab on peaches, brown rot on peaches, plums and cherries and cedar rust on apples. Use 5 to 7 pounds to 50 gallons of water. $5-\mathrm{lb} . \mathrm{pkg} .55 \mathrm{c}$

\section{Ever Green Garden Spray}

Pyrethrum Rotenone Insecticide. A nonpoisonous contact insecticide. Kills rose chafers, bean beetles, cutworms, aphis, slugs and other pests. Oz. $35 \mathrm{c}$.; 6 ozs. $\$ 1.00 ; 16 \mathrm{ozs}$. $\$ 2.15$; gal. $\$ 12.20$
Fish-Oil Soap. Dissolved in water makes an excellent spray for scale on palms, etc. 1-lb. pkg. 35c.; 5 lbs. $\$ 1.50$.

Fume-Ogen. A new scientific dog-, cat- and ant-repellent and insecticide. Powder form -convenient shaker can. 50c.

\section{ungtroden} An effective preventive and remedy for mildew, black-spot and other fungous diseases of roses and other plants; invisible on the foliage or blooms. $1 / 2 \mathrm{pt}$. 75c; pt. $\$ 1.25$; qt. $\$ 2.00$; $1 / 2$ gal. $\$ 3.50$; gal. $\$ 6.00$.

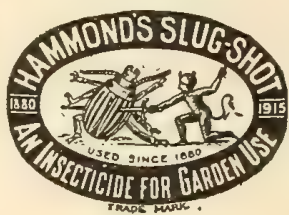

Hammond's Slug Shot. WeII-known remedy for tobacco bugs and most garden pests. 1 -lb. sifter-topcan, $30 c$ 5 Ibs. $\$ 1.20$.

\section{Acme Japanese Beetle Spray \\ Repels-Controls}

This Spray contains rotenone and other active extractives, together with strong repelling ingredients. Lb. (will make 20 gals. spray) $75 \mathrm{c}$

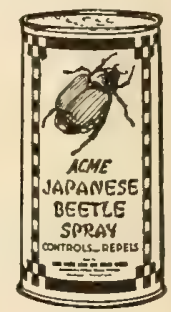

K-R-O. Kills rats and mice only. Will rid your premises without endangering your pets. 2-oz. box 75c., 4-oz, box $\$ 1.25$ Ready mixed, 6 ozs. 35 c.; 24 ozs. $\$ 1.00$.

\section{ACME LIME-SULFUR (DRY} POWDER) Widely recommended, and known as the best preparation for scale, etc. L.b. 35c.; 5-Ib. can $\$ 1.50$; 121 Ib. bag $\$ 2.00 ; 100$ Ibs. $\$ 12.00$. Write for prices on larger

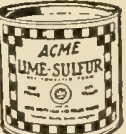
quantities.

LIME-SULFUR SOLUTION. GaI. $\$ 1.00$; 5 gals. $\$ 4.00$. Write for prices on larger quantities.

Magnesium Arsenate. Recommended for spraying bean beetles. 12-oz. can 35c.; 2 lbs. 60 c.; 100 lbs. $\$ 24.00$.

Mologen (Mole Killer). Eliminates moles from your lawns. 8-oz. can 50c.; 24-oz. can $\$ 1.25$.

New Lethane 440. For control of sucking insects. Qt. $\$ 2.40$; gal. $\$ 6.50$.

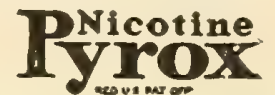

An insecticide and T fungicide that guards against all insects and blights. Lb. 59c.; 5 Ibs. $\$ 2.00$; 25 Ibs. $\$ 6.50$.

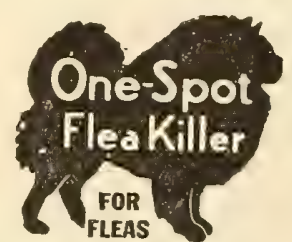

DUST ON ONE SPOT
One-Spot Flea Killer. Put a little One-Spot into your dog's dry coat anywhere on his back once a week. This is the last word in flea insurance. $25 \mathrm{c}$., $50 \mathrm{c}$. and $\$ 1.50$.

Para-Dichlorobenzene. The effective cure for peach-tree borer Lb. 60 c.; 5 Ibs. $\$ 1.60$.

ACME PARIS GREEN.

20c.; Ib. 55 c.; 5 lbs. $\$ 2.35$.

ALL PRICES ARE

SUBJECT TO CHANGE WITHOUT NOTICE

LIQUIDS NOT MAILABLE 


\section{INSECTICIDES, continued}

\section{Sor. Pomo-Green}

With nicotine. The leaf-green With nicotine, The leaf-green black-spot, mildew and external insects. Apply every week or ten days during the growing season. Lb. 80 c.; 5 lbs. $\$ 3.30$.

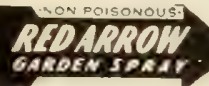

Effective against bean beetles, aphis, slugs, rose chafers and non-poisonous. Oz. 35c.; 4 ozs. $\$ 1.00$; pt. $\$ 2.85$; qt. $\$ 5.25$; gal. $\$ 16.00$.

Acme Scientific Rose Spray

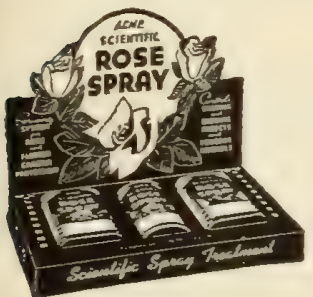

A "system" of spray treatment for roses and flowers of all kinds. Eliminates guesscontains three separate items- $\mathrm{A}, \mathrm{B}$, and $\mathrm{C}$ - each scientifrcally made to combat one of the three major classifreations of blight and insect pest. Mix all three together with water. Use regularly. Result: Complete all-round protection. Surprisingly economical.

Sizes, Amount of Spray

Prices

No. 3. 12 qts.

$\$ 095$

No. 6. 24 qts.

No. 48. $48 \mathrm{gals}$.

No. 96.

48 gals.

975

A C M E PY RETHRU M G A R D E N GUARD. Dust with Acme PyrethrumGarden Guard. The killing ingredient is now Py rethrum, noninjurious to hu$m$ a $n$ s a $n d$ warm - blooded animals. Every particle of dust

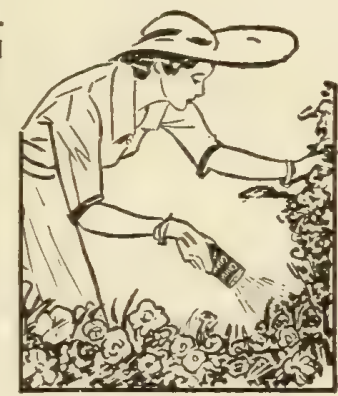
gives immediate control over a wide range of insects, including such hard-to-kill bugs as squash bugs and cucumber beetles. Acme Pyrethrum Garden Guard can be used without restriction on flowers, vegetables, and foliage of all kinds, 1.lb. sifter carton $40 \mathrm{c}$.; 4-lb. bag 75c. Write for prices in larger quantities.

Scalecide. A miscible oil used as a dormant spray against scale and other pests. Qt. 75c.; gal. $\$ 1.75 ; 5$ gals. $\$ 6.35$.

Semesan. A disinfectant for use in treating seed. 2 ozs. 40 c.; Ib. $\$ 2.50 ; 5$ Ibs. $\$ 11.40$.
Semesan, Jr. A dust disinfectant for seed

Semesan Bel. An instantaneous dip disinfectant for seed potatoes. 2 ozs. 30c. Ib. $\$ 1.65 ; 5$ lbs. $\$ 7.15$.

Snarol. An effective bait for controlling cutworms grasshoppers, snails, slugs and sowbugs. Not injurious to plants or other vegetation. $2 \frac{1}{2} \mathrm{Ibs}$. $50 \mathrm{c}$.; 6 lbs. $\$ 1.00$.

ACME STOP. A sticky treebanding compound for use on trees, shrubs, and vines to prevent insects from crawling destroy foliage. 6 ozs. 35 c.; Ib. 65 c.; 5 Ibs. $\$ 3.00$ : 10 Ibs. $\$ 5.00$

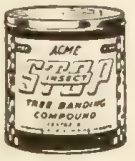

ACME WETTABLE DUSTING SULPHUR. An improved Dusting Sulphur for home use which can also be used as a liquid spray. Controls red spiders on evergreen, and mildew leaf-spot, black-spot. and rust on rose bushes, chrysanthemums, snapdragons, carna98 per cent passes through a 325-mesh screen. 2-lb. sifter carton 30c.

Sulphur for Dusting. Lb. 15c.; 10 Ibs. $\$ 1.00 ; 25$ Ibs. $\$ 2.00 ; 100$ Ibs. $\$ 7.00$.

Tobacco Dust. Lb. 10c. 10 Ibs, $50 \mathrm{c}$. 25 Ibs. $\$ 1.00 ; 100$ Ibs. $\$ 2.75$.

Tobacco Stems. Bale $\$ 2.00$.

\section{TRI-OGEN}

\section{The all-purpose sprat}

TRIPLE SPRAY TREATMENT

Complete protection against plant diseases and insects. Stimulates plant-growth. In highly concentrated form. Small Kit $\$ 1.50$; Medium Kit \$4.00; Large Kit \$6.00; Estate Kit $\$ 20.00$.

Volck. A spray for the garden, nursery and greenhouse; efectively controls red spider, mites, white flies, scales, mealy bugs, caterpillars, aphis, thrip, etc. $1 / 2$ pt. $35 \mathrm{c}$.; qt. $75 \mathrm{c}$.; gal $\$ 2.25 ; 5$ gals. $\$ 9.00$.

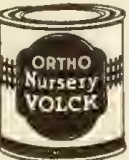

Weedex. Liquid weed-killer. Kills all undesirable plants, including poison ivy, thistles, wire grass, etc. Makes weed-free driveways, walks and tennis courts. Ot. 55 c.; gal. $\$ 1.65 ; 5$ gals. $\$ 7.50$.

Wilson's O. K. Spray. Qt. \$1.00; gal $\$ 3.00$; 5 gals. $\$ 12.00$.

\section{ACME KOPPER SHIELD PRUNING} PAINT. An antiseptic treatment for all pruning cuts and wounds in trees to protect against fungous infections of wood. $1 / 2$ pt. 30c.; pt. 45 c; q t. 75 c

Tree-Wound Paint. A penetrating antiseptic paint to prevent decay after pruning. Stops tree-bleeding. Qt. 70 c.; gal. $\$ 2.00$.

Grafting Wax. Used for grafting trees and other plants. 1/4lb. $25 \mathrm{c}$; Ib. 60 c.
Spray Catalizer. A spreader, sticker and (in place of lime caseinate. 2 Ibs. 55 c.

Ellisco Japanese Beetle Traps The use of these Traps in all parts of the beetle-infested area has proved defmitely their value ducing the annual increase. To day, their advanced design makes them the most efficient destroyer of the full-grown Japanese beetles. No. 1 Trap 50c.; No. 4 trap $\$ 1.10$.

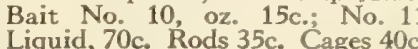
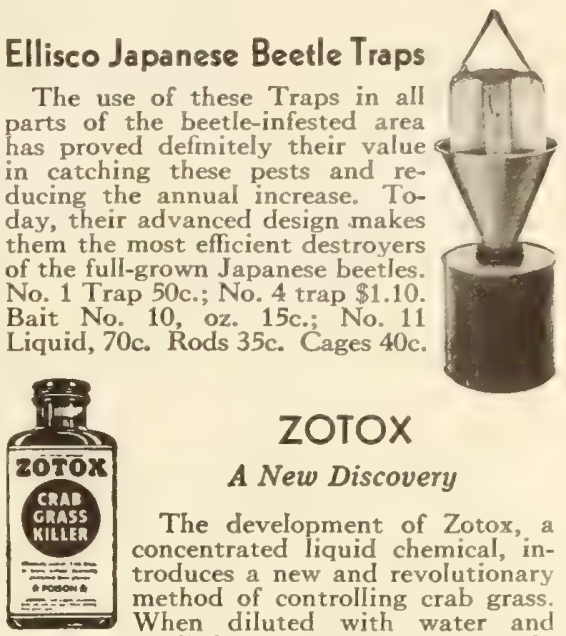

\section{ZOTOX \\ A New Discovery}

The development of Zotox, concentrated liquid chemical, in troduces a new and revolutionary method of controlling crab grass. When diluted with water an applied as a spray, Zotox not only kills the crab grass plant-it also devilalizes the seeds - thus checking reinfestation. This double-action is what makes Zotox so effective. $8-0 z$. bottle $\$ 1.00 ; 16-o z$. bottle $\$ 1.50$; 32 -oz, bottle $\$ 2.50 ; 5$-lb. bottle $\$ 4.50$.

\section{RO. 0 TON $N$}

The Hormone Powder

for Rooting Cuttings and for Dusting Seeds and Bulbs

Rootone offers the most economical, simple, efficient way for the use of plant hormones, giving twice the number of cutpowerful acetic acid-diluted with other ingredients to get the best range of activity on plants. Trial size $25 \mathrm{c}$; 2 -oz. jar $\$ 1.00 ; 1-1 \mathrm{~b}$. can $\$ 5.00$.

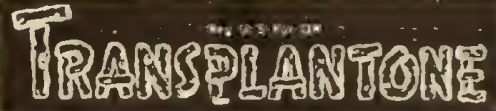

A water-soluble powder containing vitamin $B_{1}$ and other parts of the vitamin B fraction, plus certain plant hormones which are active in root-formation. Plant physiologists have shown that these chemicals are vital to the growth of plants, particularly on roots. The hormone initiates or forms roots while the vitamin $B$ chemicals are necessary for the continued growth $1 / 2=0 z, 25 c ; 0 z-50 c$ 3 ozs. $\$ 1.00$; lb. $\$ 4.00$.

\section{ROACH-NOTS}

"Lays Them on Their Back"

The universal pests known as roaches can now be safely destroyed and controlled with Roach-Nots. Trial size 25c. Estate size $\$ 1.00$

All Prices Are Subject to Change Without Notice.

Liquids Not Mailable.

\section{RAT-NOTS. "Their Last Meal"}

Rat-Nots, the ideal exterminator-non-poisonous, relatively harmless to humans and domestic animals-comes in convenient prepared bait form. No traps to clean, no mixing, no muss or fuss. Rats take to it readily on account of its tempting taste and the slow toxic effect (six to ten hours) together with the peculiar action on the rat's respiratory organs, helps to drive them outdoors. Small size 25c. Large size $\$ 1.00$.

\section{MOUSE - NOTS}

Ready to use. Mouse-Nots are placed in corners, in cupboards or where mice are in evidence. No funger-nipping traps to setno nauseating traps to clean-no mixing-no muss-no fuss. Trial size 25c. Estate size $\$ 1.00$.

MOLE-NOTS. "Life-Saver" for Lawns and seed-beds

Kills moles in their holes. Ready-to-use prepared bait. Frequent use of Mole-Nots will keep your lawn and flower-beds free from the mole nuisance. Trial size 35c. Estate size $\$ 1.00$ 


\section{$A D C O$}

A powder which, when mixed with almost any non-woody vegetable waste, such as leaves, vines and weeds, and kept moist, gradually converts the mass into real manure fully equal to the farmyard product in fertilizing power, but free from foul odor, flies, weed-seeds, etc.

150-lb. bag (enough for making 3 tor

of manure)

25-Ib. bags (enough for making $1 / 2$ ton of manure

Aluminum Sulphate. Used to make soils acid. Especially recommended for growing rhododendrons, mountain Iaurel, azaleas and other shrubs for which it is necessary to approximate the acid soil conditions of their natural habitat, such as is generally the case in virgin forests where these shrubs grow wild. Lb. 15c.; 5 lbs. 50c.; 10 lbs. $75 \mathrm{c}$

Blood-Meal (For Roses), For best results with roses, sprink a tablespoonful around the bush, about 1 inch away from it, every two weeks. It is also very valuable as a top-dressing in the vegetable garden, flower-garden, around house-plants, trees and in hothouses. Lb. 15c.; 3 Ibs. $40 \mathrm{c}$. 5 Ibs. $65 \mathrm{c}$.; $10 \mathrm{lbs}$. $\$ 1.00$.

Cotton Seed Meal. Exceedingly rich in potash and ammonia, making it excellent for use as a grass and grain fertilizer; in5 Ibs. 30c.; 10 lbs. 50c.; 25 lbs. $\$ 1.00$.

Hydrated Lime. Unexcelled for sweetening sour soil. Can be broadcast and harrowed in or mixed with the soil. For dusting of plants and trees, Hydrated Lime is one of the best materials to mix with the insecticide. It is used also as a deodorizer and for making whitewash. 10 lbs. 20c.; 50-Ib. paper sack 60c. Write for ton prices.

Land Plaster (Ground Gypsum). Should be more widely used for deodorizing manure-piles. When used for this purpose it also stops the loss of plant-food. Land Plaster is also widely used for mixing with insecticides for dusting plants, having been used for many years with Paris Green on potatoes. $50-\mathrm{lb}$. paper sack $50 \mathrm{c}$.; 80 lbs.

Nitrate of Soda. Promotes rapid growth of green material Contains 16 per cent Nitrogen. Write for prices.

Pulverized Limestone. A very finely ground lime. Not as fast as Hydrated Lime but lasts in the ground over a longer period. 80 -lb. sack $75 \mathrm{c}$.

Sulphate of Ammonia. This material will stimulate growth almost immediately. Analysis: 20 per cent Nitrogen. 100 Ibs, $\$ 2.90$

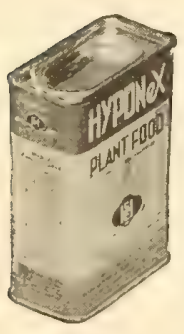

\section{Hyponex Plant-Food}

A complete and balanced Plant-Food containing al major and minor elements with vitamin $B_{1}$ added. With grow plants in soil, sand, bar-

1) ren earth or water. Hyponex has been approved and Ii censed in the agricultural departments of every state in the Union and Canada. The analysis of Hyponex isguaranteed: Nitrogen 7 per cent; available Phosphoric Acid 6 per cent; Potassium 19 per cent. (1-oz. makes 6 gals.)

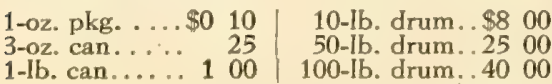

\section{cowrais PlanTabbs}

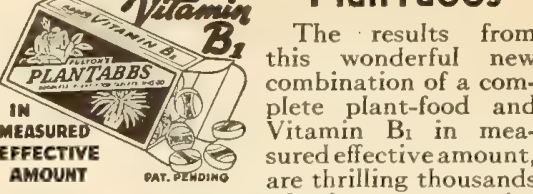

who love to grou

loor olants and garden flowers. Plan Tabbs are small, white, odorless tablets. A comthe high analysis of nitrogen 11 per cent, phosphoric acid 15 per cent, potash 20 per cent, are water-soluble, and dissolve quickly. 30 tablets $25 \mathrm{c}$.; 75 tablets $50 \mathrm{c}$; 200 tablets $\$ 1.00 ; 1000$ tablets $\$ 3.50$

\section{VITAMTN QS BASY 10 APRIY WITH 3 THOMPSONS PELIETS

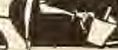 and Shake-A-Drop Bolle

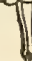 6en \\ \$1 MAKES 2000 GALS.}

Short-cuts to garden success include a regular application of Vitamin $\mathrm{B}_{1}$ this new, easy Thompson way! Most flowers, plants and shrubs need Vitamin $B_{1}$ but can't get it naturally, so vitamize the Thompson way and watch results! The new Thompson $\mathrm{B}_{1}$ Pellets and Shake-A-Drop Bottle eliminate all guesswork measuring devices. Just dissolve a Thompson Pellet in the Shake-A-Drop Bottle for basic solution. Shake a drop of this into a gallon of tap-water and apply. That's all there is to it-but do it regularly if you expect real garden success. Box of 100 Thompson Vitamin $B_{1}$ Pellets, $1 \mathrm{mg}$. each, makes 2000 gals. solution. Price including Shake-A-Drop Bottle and full directions, $\$ 1.00$; box of 10 pellets (makes 200 gals.) $25 c$

Mackwin $B_{1}$ Liquid. Bottle (makes 120 gaIs.) $35 \mathrm{c}$.
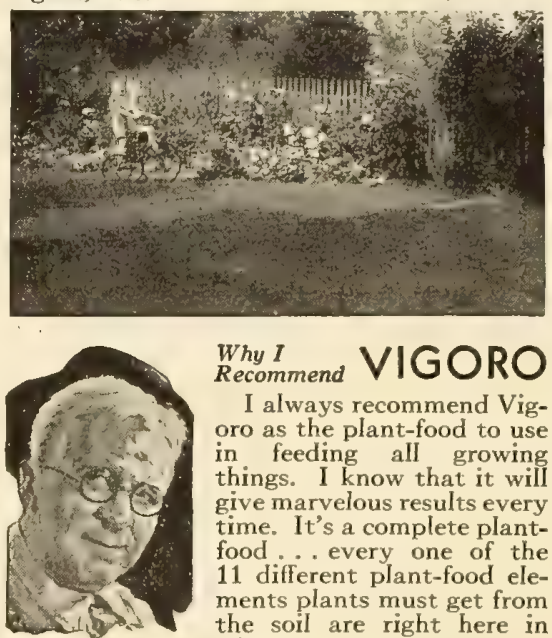

Why I
Recommend VGORO

I always recommend Vigro as the plant-food to use in feeding all growing things. I know that it will give marvelous results every time. It's a complete plantfood... every one of the 11 different plant-food elements plants must get from the soil are right here in Vigoro.

Take my advice and try Vigoro this year. Clean and odorless, it's mighty nice to work with. And it's economical, too. Use it for lawns, flowers, shrubs, trees, and vegetables. -The Master Gardener 1-lb. pkg....\$0 10 10 25-lb. bag. . \$1 50

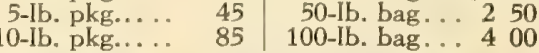

\section{VIGORO}

Tablets, 24 for 10 cts.

\section{PLANTET}

Soilless Growth Composition

Plantet is a perfectly balanced, completely soluble plant-food for use in growing plants without soil. It possesses several exclusive features which make it especially reliable as a plant nutrient. Soilless growth consists of growing plants in a medium devoid of soil and supplying to the plants' roots a water solution of all the elements necessary for flourishing plant-growth. Thus, when Plantet is dissolved in water, a nutrient solution results. $\mathrm{Pkg}$. (enough to make 35 gals. solution) $75 \mathrm{c}$. Full directions with each package.

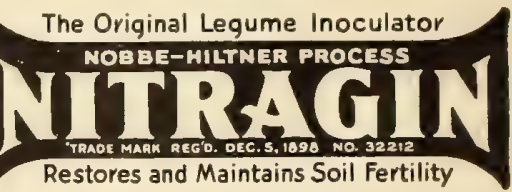

Guaranteed Fresh Each Year-Leads in High Germ Count

Agricultural colleges advise inoculation for all legume seed for profrtable results because it pays well in producing larger quality yields. Fresh, high-count Nitragin, containing billions of efficient nitrogen-gathering germs,

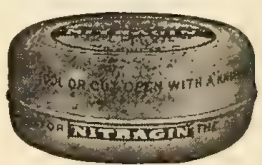
builds up the soil

All legume germs are perishable. To protect you, Nitragin cans are stamped with expiration date. Insist on Nitragin.

\section{Mixing Nitragin with Seed}

Legume germs die rapidly when dried. Nitragin, containing between 30 to 40 per cent moisture, will readily stick to the seed without adding water, and give inoculation. However, for best results, the preferred practice, recommended by The Nitragin Company and agricultural authorities, is to use water when mixing legume culture with seed.

\section{NITRAGIN PRICES}

Alfalfa, all Clovers Peas, Vetch, Beans $1 / 2$ bus.......\$0 30 Size Peas

1 bus....... 50 50 1/2 bus.... $\$ 025$

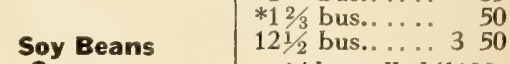

\section{Cowpeas}

2 bus.

5 bus.

25 bus.

$\$ 0$
55
250

*Also called " 100 . Ib. size."

100 Ibs....... 50

Garden Size Nitragin. For Peas, Beans, Sweet Peas. Inoculates from $1 \mathrm{oz}$. to $8 \mathrm{Ibs}$. seed. $10 \mathrm{c}$.

When ordering, always specify kind of seed Important: When ordering Nitragin, always be sure to state kind of legume seed you wish to inoculate. Nitragin has served the American farmer since 1898.

\section{Sudbury Soil-Test Kits}

This Kit is the only equipment we know of at price that tests for nitrogen, phosphorus, potash and acidity. Packaged in a stron cardboard container, it will give the gardener, who wants the best results with the least expenditure

on fertilizer, complete information about the requirements of his soil.

Home Gardener Kit.

Horticultural Kit

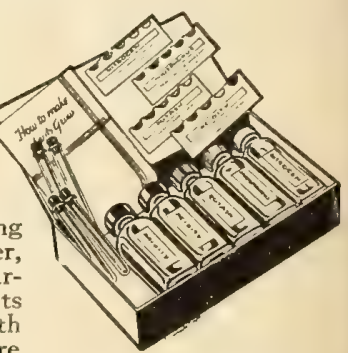

$\$ 200$

ALL PRICES SUBJECT TO CHANGE WITHOUT NOTICE. LIQUIDS NOT MAILABLE 


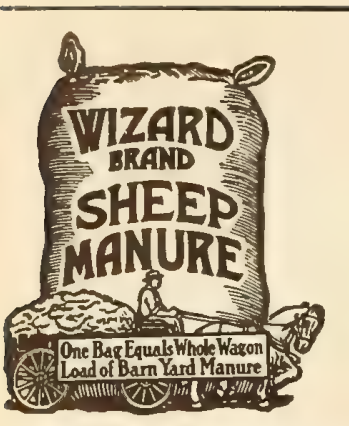

\section{Wizard Brand Manures Make All Plants Grow!}

These concentrated Manures are dehydrated and absolutely weedless. They supply an abundance of humus and all the essential plant-food elements needed to make plants thrive. They are safe for all plants under glass and are convenient and very effective for mixing compost for bench or potting soil. You'Il find Wizard unexcelled for lawns, flowers, vegetables, shrubs and trees. No matter what you grow, Wizard will give you better results because these Manures build up the soil and feed plants in nature's safe way. Avoid leached-out, inferior manures. Order $\$ 1.50 ; 100 \mathrm{lbs}$. $\$ 2.65$.

SPREADERS for applying plant-food evenly on your lawn or garden. See page 64 . ALL PRICES SUBJECT TO CHANGE WITHOUT NOTICE

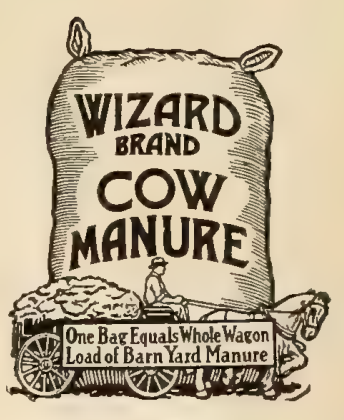

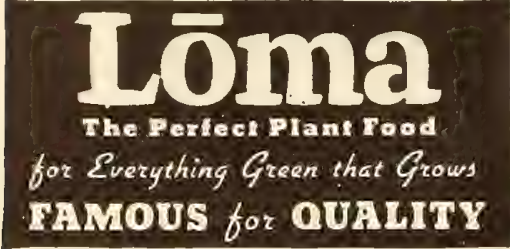

There's a Difference Worth Knowing

In addition to Loma's scientifically balanced ration of nitrogen, phosphoric acid and potash, it contains manganese, magnesium, calcium, sulphur, iron, zinc, boron, chlorine, carbon, aluminum, titanium, sodium, chromium, copper and other elements essential to plant-growth.

\section{Gardeners who know formulas choose Loma}

-Analysis-

Size $\quad$ Analysis-

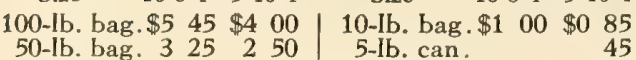
25-Ib. bag. $190 \quad 150 \quad$ 1-Ib. can

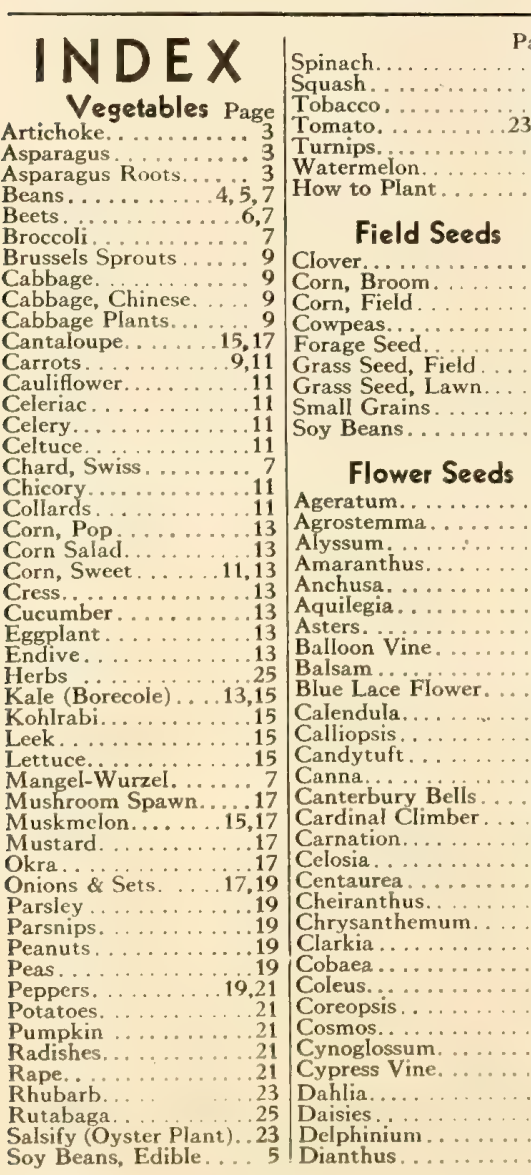

10

\section{PEAT MOSS}

FineIr granulated, thoroughly dried material of good quality. The dependable source of necessary organic matter (humus) in the soil. Free from weed seed and injurious bacteria. Maintains proper moisture content in soil, improving its condition; for propagating benches, and where layering is

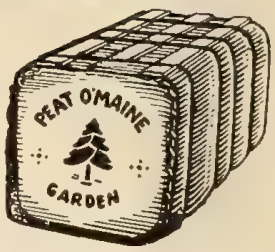
in place of sand or ashes, in potting soil; for storing bulbs and tubers over dormant season; mulching flower and vegetable beds, evergreens, roses, shrubs, etc. For making lawns and keeping them in condition and for many other purposes. Standard size bales, burlapped and protected by wooden slats, wire bound. Size about $22 \times 23 \times 36$ in. $\$ 4.00$.

\section{Eipersínimus}

NATURE'S

OWN SOIL

ENRICHER

This is rich soil humus that has been aerrated, sweetened and composted, making it an ideal top-dressing for lawns and flower-beds. Makes heavy soils light and porous, light soils heavy. Just what you need to promote plant and lawn development at the seashore. Gives immediate and permanent effect wherever used. No odor; no weeds.

For lawns use 200 Ibs. to 1,000 square feet; for vegetables and flowers spread about 1 inch thick. It will work wonders. Lb. 10c.; 5 Ibs. 20c.; $10 \mathrm{lbs}$. 30c.; $25 \mathrm{lbs}$. 50c.; $100 \mathrm{lbs}$. $\$ 1.75$; ton $\$ 25.00$.

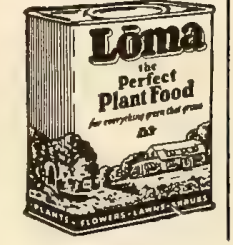

\section{Page}

Digitalis. ........... Eschscholtzia Euphorbia

17 Forget-Me-Not Four o'Clock Gaillardia.
Geranium. Geranium. Godetia Golden Feather Gomphren . Gourds. Gypsophila. Helichrysum Heliotrope Hibiscus. Hyacinth B Job's Tears 8 Kudzu Vine. Lantana. Larkspur Linaria. Lobelia Lunaria. Marigolds Marigolds. Morning-Glory Nasturtium Nemesia. Nicotiana. Nicotiana.
Nierembergia Pansies . Phlox. Poppies. Portulaca Ryrethru. Salpiglossi Salvia. Scabiosa. Scarlet Runner Bean Schizanthus Snapdragon (Antirr hinum)

\section{\begin{tabular}{|l|} 
Page \\
.33 \\
.33 \\
.33 \\
.33 \\
.33 \\
.33 \\
.33 \\
.33 \\
.33 \\
.33 \\
.34 \\
.34 \\
.34 \\
.34 \\
.34 \\
.34 \\
.34 \\
.34 \\
.34 \\
.34 \\
.34 \\
.35 \\
.35 \\
.35 \\
.35 \\
.35 \\
.35 \\
.35 \\
.35 \\
.35 \\
.35 \\
.36 \\
.35 \\
.36 \\
.37 \\
.36 \\
.36 \\
.36 \\
.37 \\
.37 \\
37.38 \\
.38 \\
38.39 \\
.39 \\
.39 \\
.39 \\
.39 \\
.39 \\
.39 \\
.39 \\
.39 \\
.29 \\
.29 \\
\hline
\end{tabular}}

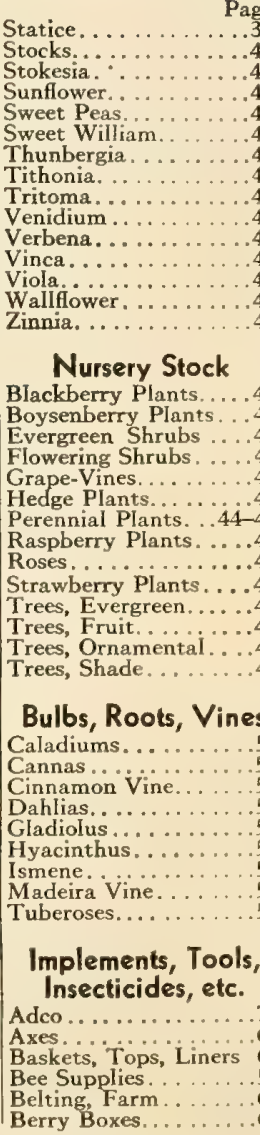

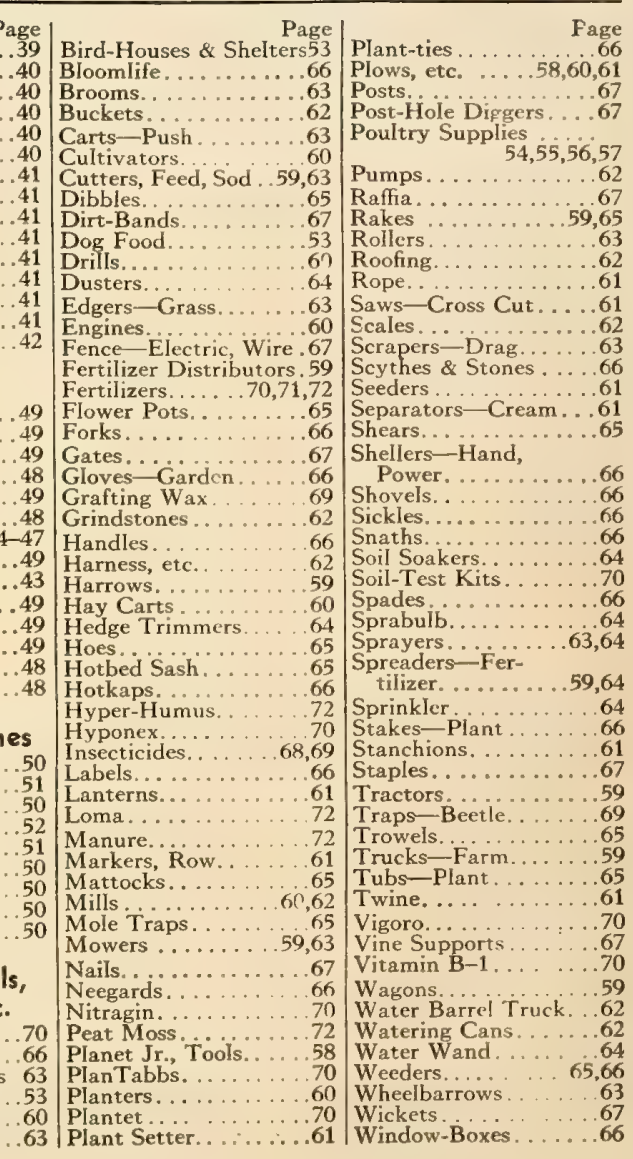




\section{FIELD SEED AND POTATO PRICES}

\section{JANUARY 20, 1943}

All prices quoted here give the values prevailing on the date this list was published. Should the prices be more or less when your order is received, you will be sent the full value of your morey at prices then prevailing. A new copy of this list with the latest prices will be sent on reauest at any time

ALL PRICES F.O.B. WASHINTON,D.C.

FOR PARCEL POST RATES SEE PAGE-2

WRITE FOR SPECIAL OUANTITY PRICES.

CORN

Hytrid 10 LBS.

Boone Co. White Sure Crop

Laricaster Co.

Hickory King

Eureka Erisilage

Leaming

Prosperity

MISCELLANEOUS 10 LBS.

White Springs Oats

Hairy vetch

D. Rape

Golden Millett

Canada Peas

Sorghum

10 LBS.

1.75

.65

$1.05 \quad 4.90$

.75

2. 15

SOY BEANS Mammoth yellow Wilson Early $\mathrm{Va}$

"
BU.

6.75

3.00

3.00

ClOVERS 10 LBS. ALFALFA

Sapling

Med. Red

Crimsor

Alsike

White Sweet

White 1b.1.co 9.50

PRICES
BU.

26.40

18.60

3.35

3.45

1.75

19.20

$8.5 \mathrm{C}$

3.45

19.20

8.70

2.75

\footnotetext{
(1)
}

Irish Cobblers
Irish Cobblers Certified
Early Rose
Red Bliss
Chippewas

\section{POTATOES}

$\begin{array}{lll}\text { Bbl. } & \text { Bu. } & \text { Peck } \\ 4.80 & 2.10 & .60 \\ 5.35 & 2.30 & .65 \\ 5.10 & 2.20 & .60 \\ 5.10 & 2.20 & .65 \\ 4.80 & 2.10 & .60\end{array}$

C.OW PEAS IO LBS.

Whippoorwill

.85

Mixed

GRASSES 10 LBS.

1. 10

3.15

10 LBS.

Kentucky Blue 3.00

Red Top

2.50

Sudan

1.00

Perennial Rye 2.50

Domestic " 1.50

Chewing Eescue 6.00

BU.

3.30

4.35

50 LBS.

10.75

6.25

3.75

9.00

5.40

24.25

BU .

3.15

3.00

\section{F. W. EOLGIANO \& CO.}

PHONE 


\section{F. W. BOLGIANO \& CO., \\ Washington, D. C.}

Date

Forward by $\left(\begin{array}{c}\text { State whether wanted by } \\ \text { Mail, Express or Freight }\end{array}\right)$

Name (Mrease prefix $)$ (Mrs. or $\mathbb{M}$ Miss)

Street, P. O. Box or

Rural Delivery

\section{Post Office}

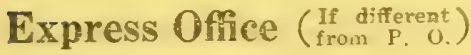

County

State

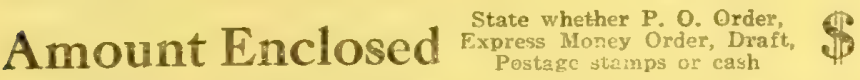

Please do not write in above space

REMITTANCFS are always safe when sent REMITTANCES are atways safe when sent or Express Money Order Personal Check, or Bank Drait. Small amounts can be sent in postage stamps, folding same in brown wrapping paper to prevent sticking.

SEFDS AND BUIBS BY FXPETSS to all pints al une of tweaty par cenc less than uoints al late of twenty per. cent less than to our cartral locatic

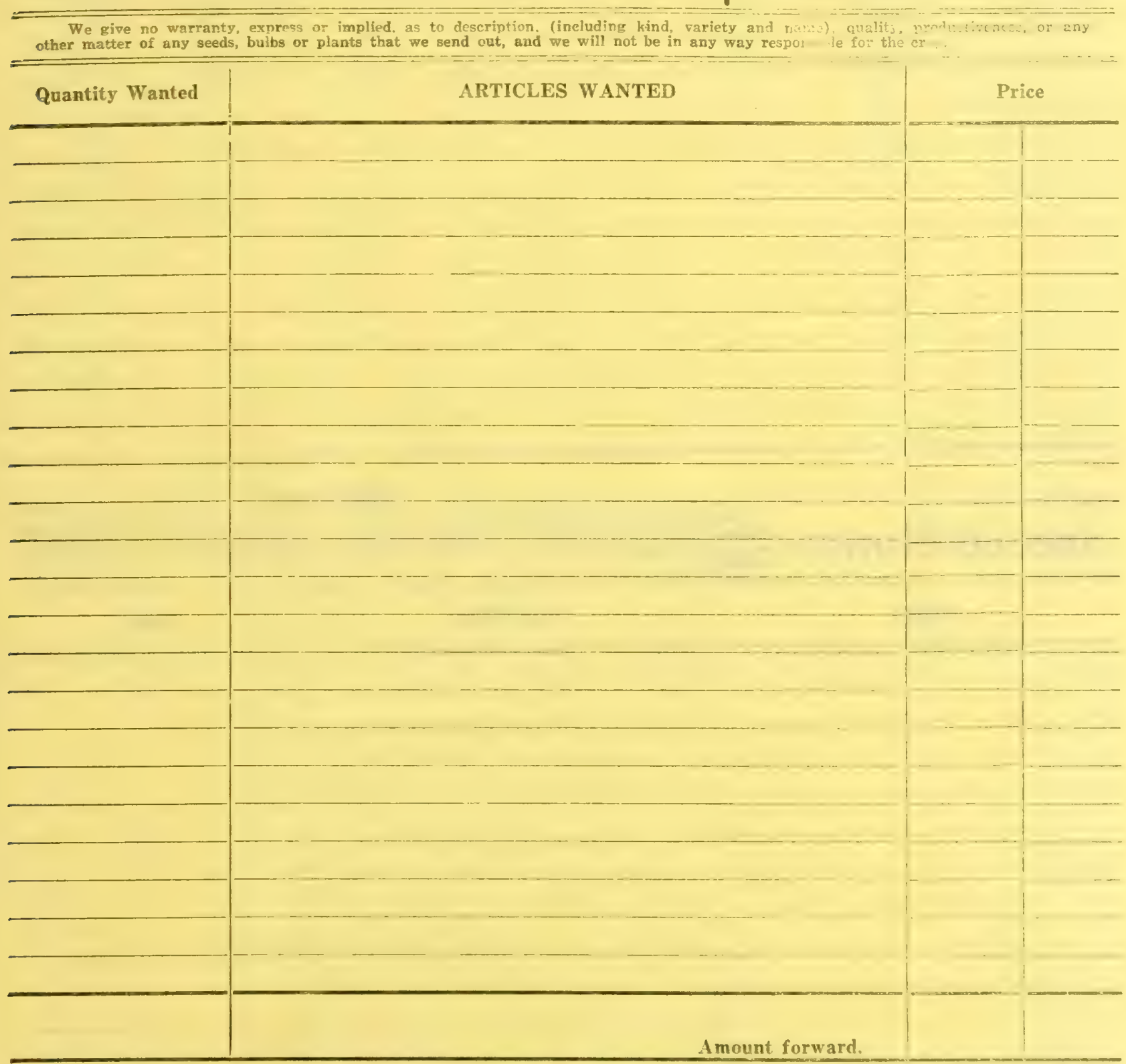

BE SURE TO INCLUDE POSTAGE FOR ARTICLES NOT POSTPAID-SEE C.IT.LOU'L 


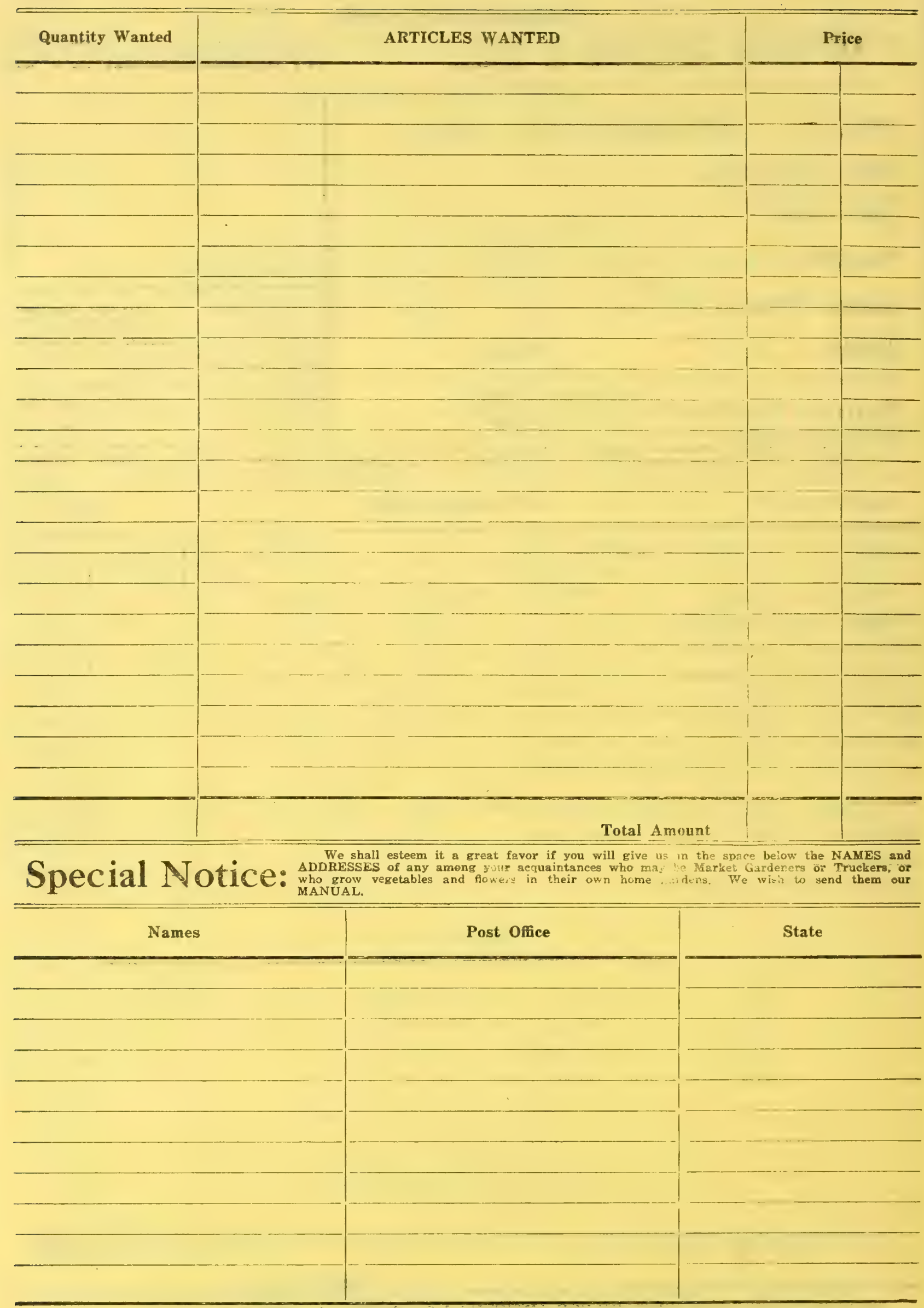


Form 6001

POST OFFICE DEPARTMENT NO
THIRD ASSISTANT POSTMASTER GENERAL

응 DIVISION OF MONEY ORDERS

Stamp of Issuing Oillce

至

She Postmaster

FEE

$\$$ hera

the office drawn on, when the office named by the remitter does not trans. act money-order business.

Spaces above this line are for Postmaster's record, to be filled in by him

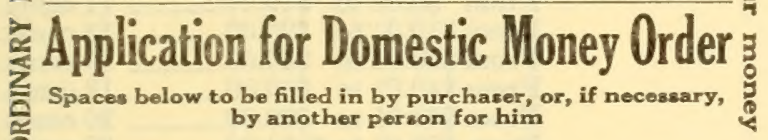
Amount-

U USE FIGURES, by another perzon for him

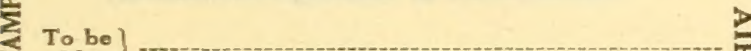

Faid to) (Name of person or firm for whom order is intended)

6 Whose ?

address
is

and

State

Sent by - 2 -....

5

State

PURCHASER MUST SEND ORDER AND COUPON TO PAYEE

(FOR FEES SEE OTHER SIDE)

$016-8391$ 


\section{Fees for Money Orders Drawn on Domestic Form}

Payable in the United States, including Hawaii, Puerto Rico, and the United States Virgin Islands, or in Guam and Tutuila (Samoa) ; also for orders payable in Antigua, Bahamas, Barbados, Bermuda, British Guiana, British Honduras, British Virgin Islands, Canada, Canal Zone, Cuba, Dominica, Grenada, Jamaica, Montserrat, Nevis, Newfoundland, Philippine Islands, St. Kitts, St. Lucia, St. Vincent, and Trinidad and Tobago.

\begin{tabular}{|c|c|c|c|}
\hline For Orders & $\begin{array}{l}\text { From } \$ 0.01 \text { to } \\
\text { From } \$ 2.51 \text { to } \\
\text { From } \$ 5.01 \text { to } \\
\text { From } \$ 10.01 \text { to } \\
\text { From } \$ 20.01 \text { to } \\
\text { From } \$ 40.01 \text { to } \\
\text { From } \$ 60.01 \text { to } \\
\text { From } \$ 80.01 \text { to }\end{array}$ & $\begin{array}{r}\$ 2.50 \\
\$ 5.00 \\
\$ 10.00 \\
\$ 20.00 \\
\$ 40.00 \\
\$ 60.00 \\
\$ 80.00 \\
\$ 100.00\end{array}$ & $\begin{array}{l}6 \text { cents. } \\
8 \text { cents. } \\
11 \text { cents. } \\
13 \text { cents. } \\
15 \text { cents. } \\
18 \text { cents. } \\
20 \text { cents. } \\
22 \text { cents. }\end{array}$ \\
\hline
\end{tabular}

Memoranda of Issuing Postmaster:

If order is purchased through Rural Carrier, he will fill spaces below:

Carrier's receipt No.

Carrier.

NoTE.- The maximum amount for which a single Money Order may be issued is $\$ 100$. When a larger sum is to be sent additional Orders must be obtained. Any number of Orders may be drawn

on any Money Order office on any one day. years from date of issue.

(EDITION JUNE 1939) 16-8391 

Mrs. Sam

McGredy

$80 \mathrm{c}$ each

\section{BOLGIANO'S}

Capitol City

6

Beautiful

ROSES

Etoile de Hollande $80 \mathrm{c}$ each

SPECIAL OFFER

One of each variety shown on this page for

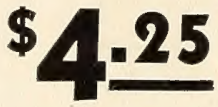

POSTPAID

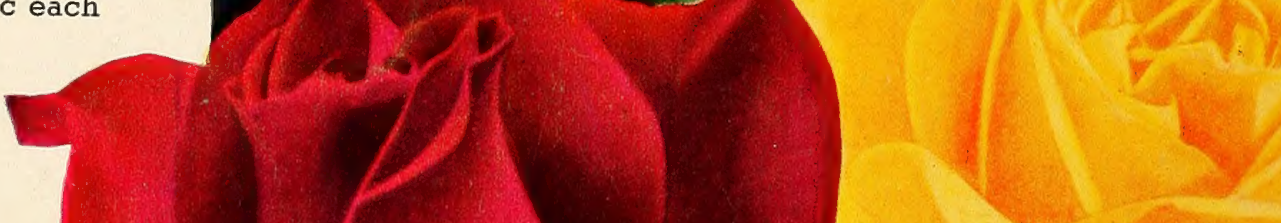

Mrs. Pierre

S. du Pont

$80 \mathrm{c}$ each

POSTPAID

.

